FINAL REPORT

\title{
MINELAND RECLAMATION USING OFFICE WASTE PAPER DE-INKING RESIDUE
}

\author{
By \\ Barbara J. McCarthy \\ Stephen D. Geerts \\ Kurt W. Johnson \\ Thomas J. Malterer \\ Craig C. Maly
}

March 1994 (Revised 10103194)

Prepared for:

Subaccount No. 543845

Phase III

NRRI/TR-94/16

Minnesota Office of

Environmental Assistance

1350 Energy Lane

St. Paul, MN 55108

Natural Resources Research Institute University of Minnesota, Duluth 5013 Miller Trunk Highway

Duluth, Minnesota 55811 


\section{TABLE OF CONTENTS}

LIST OF TABLES $\ldots \ldots \ldots \ldots \ldots \ldots \ldots \ldots$ ii

LIST OF FIGURES $\ldots \ldots \ldots \ldots \ldots \ldots \ldots \ldots \ldots$ iv

LIST OF APPENDICES $\ldots \ldots \ldots \ldots \ldots \ldots \ldots \ldots$ vii

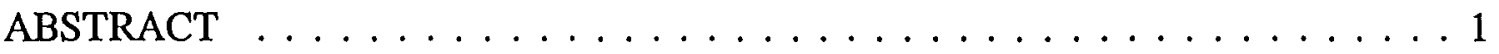

INTRODUCTION AND BACKGROUND $\ldots \ldots \ldots \ldots \ldots \ldots$

RESEARCH OBJECTIVE $\ldots \ldots \ldots \ldots \ldots \ldots \ldots \ldots \ldots$

MATERIALS AND METHODS

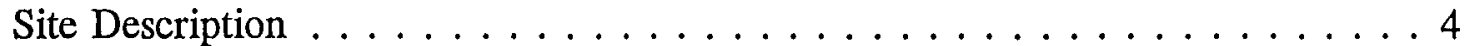

Experimental Design . . . . . . . . . . . . . . . . . . 4

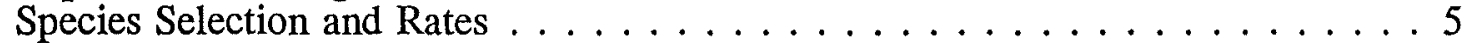

Plot Establishment $\ldots \ldots \ldots \ldots \ldots \ldots \ldots \ldots \ldots \ldots \ldots \ldots \ldots \ldots \ldots$

Lysimeter Installation, Sampling and Analysis $\ldots \ldots \ldots \ldots \ldots$

Vegetative Cover Determinations, Plant Sampling and Analysis . . . . . . . 7

De-Inking Residue and Coarse Tailings Sampling and Analysis . . . . . . . 7

RESULTS AND DISCUSSION

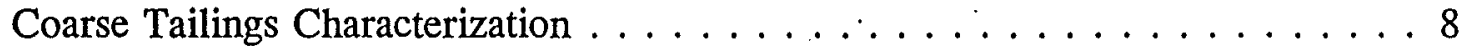

De-inking Residue Characterization . . . . . . . . . . . . . 10

Coarse Tailings Amended with Residue Characterization . . . . . . . . . 11

Treatments without Fertilizer $\ldots \ldots \ldots \ldots \ldots \ldots \ldots 12$

Treatments with Fertilizer at the Highest Rate $\ldots \ldots \ldots \ldots \ldots$

Lysimeter Analysis

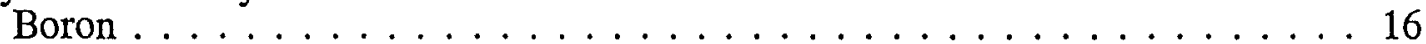

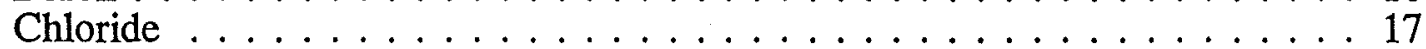

Nitrite + Nitrate-Nitrogen $\ldots \ldots \ldots \ldots \ldots \ldots \ldots \ldots \ldots$

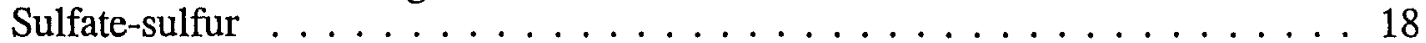

Percent Vegetative Cover

July 1992 -Introduced Species $\ldots \ldots \ldots$. . . . . . . . . . . . . . . . . 19

July $1992-$ Native Species . . . . . . . . . . . . . . . . . . . . 20

September 1992-Introduced Species $\ldots \ldots \ldots \ldots \ldots \ldots \ldots \ldots \ldots . \ldots . \ldots 21$

September 1992-Native Species . . . . . . . . . . . . . . . . . 22

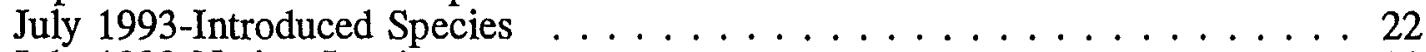

July $1993-$ Native Species $\ldots \ldots \ldots \ldots \ldots \ldots \ldots \ldots \ldots \ldots$

September $1993-$ Introduced Species $\ldots \ldots \ldots \ldots \ldots \ldots \ldots$. . . . . . 24

September 1993-Native Species . . . . . . . . . . . . . . . . . . . 26

Vegetative Cover Over Time $\ldots \ldots \ldots \ldots \ldots \ldots \ldots$

Chemical Analysis of Vegetation

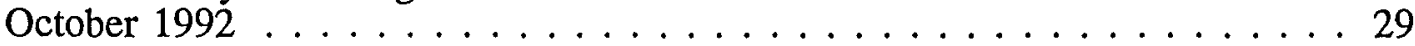

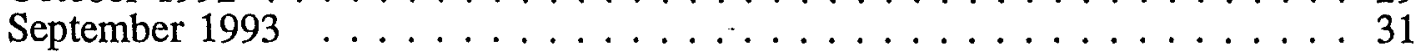

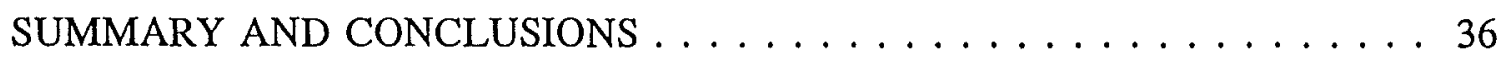

RECOMMENDATIONS . . . . . . . . . . . . . . . . . . . . 39

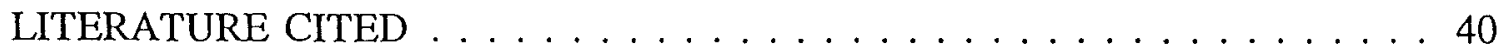

G:IBPOFFICEIREPORTSI543845.III 


\section{LIST OF TABLES}

Table 1.--Plant species and seeding rates used in the establishment of mineland reclamation plots at Eveleth Mines in May $1992 \ldots \ldots$. . . . . . . . . . 4

Table 2.--Mean chemical characteristics of coarse taconite tailings prior to the application of de-inking residue and fertilizer $\ldots \ldots \ldots \ldots \ldots$

Table 3.--Mean chemical characteristics of de-inking residue $\ldots \ldots \ldots$. . . . 45

Table 4.--Chemical properties of coarse tailings amended without commercial fertilizer where introduced species were planted in May 1992 . . . . . . . . . 47

Table 5.--Chemical properties of coarse tailings amended without commercial fertilizer where native species were planted in May $1992 \ldots \ldots$. . . . . . . 48

Table 6.--Chemical properties of coarse tailings amended with commercial fertilizer $\left(\mathrm{N}=160 \mathrm{lb} / \mathrm{acre}, \mathrm{P}_{2} \mathrm{O}_{5}=359 \mathrm{lb} / \mathrm{acre}\right)$ where introduced species were planted in May 1992 . . . . . . . . . . . . . . . . . . . . . . . . . 49

Table 7.--Chemical properties of coarse tailings amended with commercial fertilizer $\left(\mathrm{N}=160 \mathrm{lb} / \mathrm{acre}, \mathrm{P}_{2} \mathrm{O}_{5}=359 \mathrm{lb} / \mathrm{acre}\right)$ where native species were planted

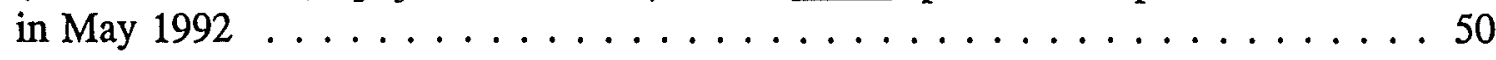

Table 8.--The mean percent vegetative cover of introduced plant species measured in July 1992 at Eveleth Mines . . . . . . . . . . . . . . . . . . . . . . . . 51

Table 9.--The mean percent vegetative cover of native plant species measured in July 1992 at Eveleth Mines . . . . . . . . . . . . . . . . . . . . . . . . . 51

Table 10.--The mean percent vegetative cover of introduced plant species measured in September 1992 at Eveleth Mines . . . . . . . . . . . . . . . . . . . 52

Table 11.--The mean percent vegetative cover of native plant species measured in September 1992 at Eveleth Mines . . . . . . . . . . . . . . . . . . 53

Table 12.--The mean percent vegetative cover of introduced plant species measured in July 1993 at Eveleth Mines . . . . . . . . . . . . . . . . . . . . . . . . . 54

Table 13.--The mean percent vegetative cover of native plant species measured in July 1993 at Eveleth Mines . . . . . . . . . . . . . . . . . . . . . . . . 55

Table 14.--The mean percent vegetative cover of introduced plant species measured in September 1993 at Eveleth Mines . . . . . . . . . . . . . . . . . . . 56 
Table 15.--The mean percent vegetative cover of native plant species measured in September 1993 at Eveleth Mines . . . . . . . . . . . . . . . . . . . . 57

Table 16.--Published critical values for alfalfa grown in pure stands for whole plants and phytotoxic levels of cadmium, chromium, nickel, and lead that can occur

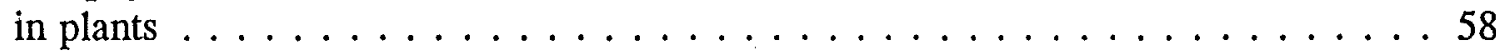

Table 17.--Chemical analysis for plant samples of introduced species collected from selected plots at Eveleth Mines in October 1992 . . . . . . . . . . . . . 59

Table 18.--Plant analysis of Medicago sativa (alfalfa) at Eveleth Mines, fall 1993, grouped by de-inking residue rate $\ldots \ldots \ldots \ldots \ldots \ldots$

Table 19.--Plant analysis of Fagopyrum esculentum (buckwheat) at Eveleth Mines, fall $1993 \ldots \ldots \ldots$. . . . . . . . . . . . . . . . . . . . . . . . 61

Table 20.--Plant analysis of Festuca rubra (red fescue) at Eveleth Mines, fall 199362

Table 21.--Plant analysis of Bromus inermis (smooth bromegrass) at Eveleth Mines, fall $1993 \ldots \ldots \ldots$. . . . . . . . . . . . . . . . . . . . . . .663

Table 22.--Plant analysis of Andropogon gerardii and Schizachyrium scoparium (big and little bluestem) at Eveleth Mines, fall 1993, grouped by de-inking residue rate 64

Table 23.--Plant analysis of Andropogon gerardii and Schizachyrium scoparium (big and little bluestem) at Eveleth Mines, fall 1993, grouped by fertilizer rate . . . . 65

Table 24.--Plant analysis of Elymus canadensis (Canada wild rye) at Eveleth Mines, fall $1993 \ldots \ldots \ldots$. . . . . . . . . . . . . . . . . . . . . 66

Table 25.--Plant analysis of Bromus kalmii (kalm's brome) at Eveleth Mines, fall $1993 \ldots \ldots$. . . . . . . . . . . . . . . . . . . . . . . . . . . . 67

Table 26.--Plant analysis of volunteer plant species at Eveleth Mines, fall $1993 \ldots \ldots \ldots$. . . . . . . . . . . . . . . . . . . . 68 


\section{LIST OF FIGURES}

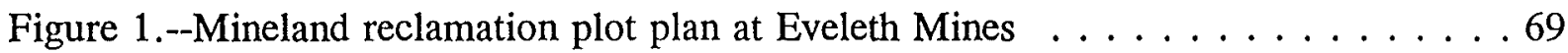

Figure 2.--Mineland reclamation plot plan for replication 1 at Eveleth Mines . . . . . 70

Figure 3.--Mineland reclamation plot plan for replication 2 at Eveleth Mines . . . . . 71

Figure 4.--Mineland reclamation plot plan for replication 3 at Eveleth Mines . . . . . 72

Figure 5.--Lysimeter analysis for boron on tailings amended with residue at 0,20 , and 80 ton/acre without fertilizer . . . . . . . . . . . . . . . 73

Figure 6.--Lysimeter analysis for boron on tailings amended with residue at 0,20 , and 80 ton/acre and $200 \mathrm{lb} /$ acre $18-46-0 \ldots \ldots \ldots \ldots \ldots$

Figure 7.--Lysimeter analysis for boron on tailings amended with residue at 0,20 , and 80 ton/acre and $400 \mathrm{lb} /$ acre $18-46-0 \ldots \ldots \ldots \ldots . \ldots 74$

Figure 8.--Lysimeter analysis for chloride on tailings amended with residue at 0,20 , and 80 ton/acre without fertilizer . . . . . . . . . . . . . . . . . 74

Figure 9.--Lysimeter analysis for chloride on tailings amended with residue at 0,20 , and 80 ton/acre and $200 \mathrm{lb} /$ acre $18-46-0 \ldots \ldots \ldots \ldots 75$

Figure 10.--Lysimeter analysis for chloride on tailings amended with residue at 0,20 , and 80 ton/acre and $400 \mathrm{lb} / \mathrm{acre} 18-46-0 \ldots \ldots \ldots \ldots . \ldots 75$

Figure 11.--Lysimeter analysis for nitrate-nitrogen on tailings amended with residue at

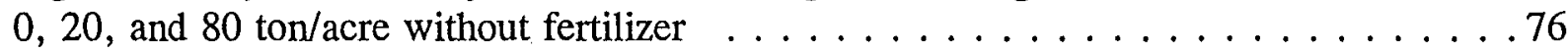

Figure 12.--Lysimeter analysis for nitrate-nitrogen on tailings amended with residue at 0,20 , and 80 ton/acre and $200 \mathrm{lb} /$ acre $18-46-0 \ldots \ldots \ldots \ldots \ldots$

Figure 13.--Lysimeter analysis for nitrate-nitrogen on tailings amended with residue at 0,20 , and 80 ton/acre and $400 \mathrm{lb} /$ acre $18-46-0 \ldots \ldots \ldots \ldots 77$

Figure 14.--Lysimeter analysis for sulfate-sulfur on tailings amended with residue at

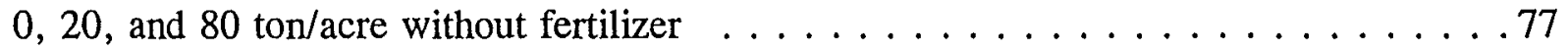

Figure 15.--Lysimeter analysis for sulfate-sulfur on tailings amended with residue at 0,20 , and 80 ton/acre and $200 \mathrm{lb} /$ acre $18-46-0 \ldots \ldots \ldots \ldots$

Figure 16.--Lysimeter analysis for sulfate-sulfur on tailings amended with residue at 0,20 , and 80 ton/acre and $400 \mathrm{lb} /$ acre $18-46-0 \ldots \ldots \ldots \ldots . \ldots 78$ 
Figure 17.--The mean percent vegetative cover for introduced plant species measured in July 1992 by fertilizer treatment . . . . . . . . . . . . . . . . . . . . . . . 79

Figure 18.--The mean percent vegetative cover for native plant species measured in July 1992 by fertilizer treatment . . . . . . . . . . . . . . . . . . . . . . . 79

Figure 19.--The mean percent vegetative cover for introduced plant species measured in September 1992 by fertilizer treatment . . . . . . . . . . . . . . . . . . 80

Figure 20.--The mean percent vegetative cover for native plant species measured in September 1992 by fertilizer treatment. . . . . . . . . . . . . . . . . . 80

Figure 21.--The mean percent vegetative cover for introduced plant species measured in July 1993 by fertilizer treatment. . . . . . . . . . . . . . . . . . . . . . 81

Figure 22.--The mean percent vegetative cover for native plant species measured in July 1993 by fertilizer treatment $\ldots \ldots \ldots \ldots$. . . . . . . . . . . . . 81

Figure 23.--The mean percent vegetative cover for introduced plant species measured in September 1993 by fertilizer treatment . . . . . . . . . . . . . . . . . 82

Figure 24.--The mean percent vegetative cover for native plant species measured in

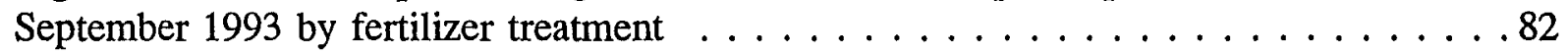

Figure 25.--The mean percent cover, over time, for introduced species treated with de-inking residue and no commercial fertilizer $\ldots \ldots \ldots \ldots \ldots$

Figure 26.--The mean percent cover, over time, for native species treated with

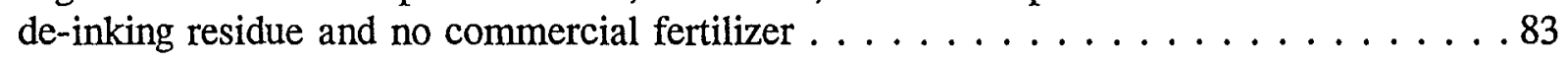

Figure 27.--The mean percent cover, over time, for introduced species treated with de-inking residue and commercial fertilizer at $\mathrm{N}=36 \mathrm{lb} /$ acre and $\mathrm{P}_{2} \mathrm{O}_{5}=92 \mathrm{lb} /$ acre $\ldots 84$

Figure 28.--The mean percent cover, over time, for native species treated with de-inking residue and commercial fertilizer at $\mathrm{N}=36 \mathrm{lb} /$ acre and $\mathrm{P}_{2} \mathrm{O}_{5}=92 \mathrm{lb} /$ acre $\ldots 84$

Figure 29.--The mean percent cover, over time, for introduced species treated with de-inking residue and commercial fertilizer at $\mathrm{N}=72 \mathrm{lb} /$ acre and $\mathrm{P}_{2} \mathrm{O}_{5}=184 \mathrm{lb} / \mathrm{acre} \ldots 85$

Figure 30.--The mean percent cover, over time, for native species treated with de-inking residue and commercial fertilizer at $\mathrm{N}=72 \mathrm{lb} /$ acre and $\mathrm{P}_{2} \mathrm{O}_{5}=184 \mathrm{lb} / \mathrm{acre} \ldots 85$

Figure 31.--The mean percent cover, over time, for introduced species treated with de-inking residue and commercial fertilizer at $\mathrm{N}=80 \mathrm{lb} /$ acre and $\mathrm{P}_{2} \mathrm{O}_{5}=180 \mathrm{lb} / \mathrm{acre} \ldots 86$ 
Figure 32.--The mean percent cover, over time, for native species treated with de-inking residue and commercial fertilizer at $\mathrm{N}=80 \mathrm{lb} / \mathrm{acre}$ and $\mathrm{P}_{2} \mathrm{O}_{5}=180 \mathrm{lb} / \mathrm{acre}$. 86

Figure 33.--The mean percent cover, over time, for introduced species treated with de-inking residue and commercial fertilizer at $\mathrm{N}=160 \mathrm{lb} / \mathrm{acre}$ and $\mathrm{P}_{2} \mathrm{O}_{5}=359 \mathrm{lb} /$ acre $\ldots 87$

Figure 34.--The mean percent cover, over time, for native species treated with de-inking residue and commercial fertilizer at $\mathrm{N}=160 \mathrm{lb} /$ acre and $\mathrm{P}_{2} \mathrm{O}_{5}=359 \mathrm{lb} /$ acre $\ldots \ldots .87$

Figure 35.--The mean concentration of boron in alfalfa (with standard error bars), across fertilizer treatments by residue rate $\ldots \ldots \ldots \ldots \ldots$

Figure 36.--The mean concentration of magnesium in alfalfa (with standard error bars), across fertilizer treatments by residue rate $\ldots \ldots \ldots \ldots \ldots$

Figure 37.--The mean concentration of manganese in alfalfa (with standard error bars), across fertilizer treatments by residue rate . . . . . . . . . . . . . . . 89

Figure 38.--The mean concentration of calcium in bluestem (with standard error bars), across fertilizer treatments by residue rate $\ldots \ldots \ldots \ldots \ldots$

Figure 39.--The mean concentration of magnesium in bluestem (with standard error bars), across fertilizer treatments by residue rate $\ldots \ldots \ldots \ldots \ldots$

Figure 40.--The mean concentration of manganese in bluestem (with standard error bars), across fertilizer treatments by residue rate $\ldots \ldots \ldots \ldots 1$

Figure 41.--The mean concentration of zinc in bluestem (with standard error bars), across fertilizer treatments by residue rate $\ldots \ldots \ldots \ldots 1$ 


\section{LIST OF APPENDICES}

Appendix A. The chemical analyses for coarse tailings/residue mixtures sampled four times in 1992 and 1993 after plot establishment.

A-1.--Nutrient analysis of coarse tailings/residue mixture, spring 1992.

A-2.--Nutrient analysis of coarse tailings/residue mixture, fall 1992.

A-3.--Nutrient analysis of coarse tailings/residue mixture, spring 1993.

A-4.--Nutrient analysis of coarse tailings/residue mixture, fall 1993.

Appendix B. The chemical analyses for lysimeters sampled eight times in 1992 and 1993.

B-1.--Lysimeter water analysis for June 1992.

B-2.--Lysimeter water analysis for July 1992.

B-3.--Lysimeter water analysis for August 1992.

B-4.--Lysimeter water analysis for September 1992.

B-5.--Lysimeter water analysis for April 1993.

B-6.--Lysimeter water analysis for June 1993.

B-7.--Lysimeter water analysis for August 1993.

B-8.--Lysimeter water analysis for September 1993. 


\begin{abstract}
Pulp facilities which recycle office waste paper generate a large amount of waste by-products in the process of producing high-grade pulp. The paper-like residue, called de-inking residue, was evaluated for use in the restoration of vegetation on coarse taconite tailings in NE Minnesota. The mineland reclamation rules specify that a 90 percent vegetative cover shall be established on tailings after three growing seasons, however this level of cover on coarse tailings has not been consistently achieved in Minnesota using standard restoration practices. Research plots were established in 1992 at Eveleth Mines arranged in a randomized block design with three replications using five levels of de-inking residue, five levels of fertilization and two plant mixes. A total of twenty-five treatment combinations were assigned to $2.5 \mathrm{~m}$ - by- $4.0 \mathrm{~m}$ plots and lysimeters were installed to monitor changes in sub-surface water quality. Coarse tailings were evaluated to determine the effects of de-inking residue on their chemical properties. Vegetative cover was measured in July and September in 1992 and 1993 and nutrient levels were determined in plant samples. Fertilization and de-inking residue amendments had significant effects on the vegetative cover of both introduced and native plant species. De-inking residue had a minimal impact on the chemical properties of coarse tailings at rates up to 80 dry ton/acre and on sub-surface water quality at a depth of four feet. Vegetative cover for introduced species increased from no cover, to 49 percent the first growing season, to 90 percent at the end of the second growing season on tailings fertilized at the highest level and amended with residue at 10 ton/acre. At the same fertilizer and de-inking residue rate, vegetative cover for native plants increased from no cover to 7 percent the first growing season, to 69 percent at the end of the second growing season. Alfalfa had lower levels of boron, magnesium, and manganese on residue amended plots in 1992 and 1993. Bluestem had higher levels of calcium and zinc, but lower levels of magnesium and manganese on residue amended plots. Cadmium, chromium, copper, nickel, lead, and zinc in alfalfa and bluestem did not accumulate to toxic levels. Deinking residue appears to have benefited vegetative growth after two growing seasons using deinking residue applied at 10 dry ton/acre with fertilizer applied at $160 \mathrm{lb} /$ acre of nitrogen and $359 \mathrm{lb} /$ acre of phosphorus.
\end{abstract}

\title{
INTRODUCTION AND BACKGROUND
}

This report is the Final Report for Phase III of the Minnesota Office of Environmental Assistance funded project "Evaluation of Uses of De-inking Residue." Phase III of this project was previously entitled "Mineland Reclamation."

A multi-million dollar paper recycling facility began production in Duluth, Minnesota in August 1993. The facility, Superior Recycled Fiber Industries (SRFI), is expected to produce 90,000 tons of premium grade, high post-consumer content recycled pulp annually using approximately 120,000 tons of office waste paper. The recycled pulp is used by area-wide paper mills to produce premium grades of paper.

As a by-product of this paper recycling process, approximately 166 wet tons of paper-like residue is expected to be produced daily. The paper-like residue produced at SRFI is termed de-inking residue. This residue is composed of approximately 50 percent water and 50 percent solids. The parent company, Synertec, Inc., is interested in utilizing this residue, which is 
currently landfilled, in a beneficial and environmentally-safe manner. Some of the beneficial uses of de-inking residue being considered include its use in the restoration of mineland, on agricultural land as a soil amendment, composting the residue for horticultural and landscaping applications, and as a component of lightweight aggregate.

De-inking residue is generated as a result of various mechanical and chemical processes used to remove contaminants from recycled office paper. Some of the contaminants that must be removed to produce a premium grade pulp, include clay, ink, calcium carbonate, and damaged wood fibers. Trace amounts of other contaminants that may be present include dioxins and furans, depending upon the composition of the recycled paper contained in the incoming paper waste stream.

Use of de-inking residue as a soil amendment could improve the physical, chemical, or biological properties of soils which, in turn, could benefit plant growth. Through the addition of residues to problematic soils, improvement to soil structure, porosity, water holding capacity, cation exchange capacity, organic matter, and soil pH could occur.

One potential beneficial use of de-inking residue could be its use in the restoration of vegetation on land used for the disposal of taconite tailings. Taconite tailings are a by-product of iron ore mining. The Mesabi Iron Range in northeastern Minnesota covers an extensive area occupied by large open-pit taconite mines. Associated with these large mining operations, are large stockpiles of mining waste, and in some operations, large stockpiles of rock overburden.

Taconite is a local term used in the Lake Superior iron-bearing district of Minnesota for any bedded chert that contains iron mineralization usually as hematite and magnetite. The term is specifically applied to rock containing at least 25 percent iron, thus, a large volume of waste rock is generated in the production of iron ore from taconite. After taconite is mined from large open-pits, the ore is crushed, finely ground, concentrated and processed into one half-inch diameter pellets. Typically, for each ton of pellets produced, approximately 2 tons of tailings are produced.

Taconite tailings are largely silicates and are commonly referred to as coarse and fine tailings. Coarse tailings are used in the construction of tailing basins, which are required to contain fine tailings produced during the production of taconite pellets. Since fine tailings are small-sized particles, these materials are easy to re-vegetate because fine tailings generally retain enough moisture and nutrients for successful vegetative restoration. In general, fine tailings are revegetated using a standard seed mix, commercial fertilizer, and straw mulch.

Coarse tailings are more difficult to re-vegetate than fine tailings because of poor inherent physical, chemical, and biological properties. Coarse tailings are sand-size particles, susceptible to wind and water erosion. If these particles become air-borne, they can both "sand" blast and bury young plant seedlings. Because coarse tailings are dark in color, the tailings tend to absorb and retain heat, which results in high temperatures at the surface during the summer months. High temperatures can cause heat stress and increase the mortality of young plants growing under these severe environmental conditions. 
The chemical properties of coarse tailings are not conducive to plant growth. Coarse tailings have a high (alkaline) $\mathrm{pH}$, lack organic carbon and organic matter, have a low cation exchange capacity, a low ability to hold moisture, and lack nutrients essential for plant growth, including nitrogen, phosphorus, calcium and magnesium. Coarse tailings can have high levels of manganese, which can be phytotoxic to plants. Biologically, coarse tailings lack many of the soil microorganisms required for nutrient mineralization, plant establishment, and growth.

In order to successfully stabilize coarse tailings with an adequate vegetative cover, the poor physical, chemical, and biological properties of coarse tailings. must be improved through the addition of both plant nutrients and organic amendments. The restoration of coarse tailings has been attempted through the use of standard restoration practices; a specified seed mix with high rates of inorganic fertilizer and a straw/hay mulch. However, the long-term vegetative stabilization of coarse tailings has been inhibited because of the lack of organic matter and microbial activity, low fertility levels, and low available water holding capacity of the tailings.

The Minnesota Department of Natural Resources (DNR) Mineland Reclamation Rules, Chapter 6130.0100 through 6130.5200 (DNR, 1980), specify that "Vegetation shall be established to control erosion, prevent and control leaching of toxic substances, screen mining areas from noncompatible uses, and provide wildlife habitat or other uses such as pasture or timber land." In northeastern Minnesota, there are approximately 25,000 acres of active tailings basins that will need to be restored with vegetation when these basins are no longer used (Dewar and Berglund, 1983).

The Mineland Reclamation Rules state that "After three growing seasons following the point when, according to the permit to mine, a surface, structure, facility, or element is no longer scheduled to be disturbed or used in a manner that would interfere with establishment and maintenance of vegetation, a 90 percent ground cover, consisting of living vegetation and its litter, shall exist on all areas, except slopes which primarily face south and west. Such sloped areas shall attain the 90 percent ground cover requirement within 5 growing seasons following the point when initiation of vegetation is required."

The rules further state that within 10 growing seasons, "an area shall have a vegetative community with characteristics similar to those in an approved reference area." Lastly, the rules specify that the area "shall be self-sustaining, regenerating, or in a recognized vegetation succession which provides wildlife habitat or other uses such as pasture or timber land."

The U.S. Bureau of Mines has established research plots on coarse tailings at several locations in northeast Minnesota, including Eveleth Mines, using organic amendments. The Bureau of Mines (Norland, 1993; Norland, Veith and Dewar, 1993) and the DNR (Melchert et al., 1994) indicate that standard methods of site re-vegetation have not been successful and that new technologies are needed in order to achieve adequate re-vegetation. It has been estimated that many of the dams and dikes constructed using coarse tailings have only attained a 40-60 percent plant cover after 3 years (Shetron and Duffeck, 1970; Dewar, 1987). 


\section{RESEARCH OBJECTIVE}

The objectives of this two-year study were to determine the: 1) optimum application rates of deinking residue, with and without fertilizer, in an attempt to achieve 90 percent vegetative cover; and 2) environmental impacts of de-inking residue, with and without fertilizer, on coarse tailings, vegetation, and sub-surface water.

\section{MATERIALS AND METHODS}

\section{SITE DESCRIPTION}

Field research plots were established in 1992 at the Eveleth Mines Fairlane Plant near Forbes, Minnesota on coarse taconite tailings. The research plots were established adjacent to existing plots established by the Bureau of Mines in May 1990. The Bureau of Mines plots were established to determine the effectiveness of using organic amendments, including composted yard waste, MSW composts containing disposable diapers, and reed-sedge peat in the revegetation of coarse tailings.

Northeastern Minnesota is characterized by harsh climatic conditions; short, warm summers and long, cold snowy winters. The average annual precipitation, based upon weather data from a nearby weather station in Hibbing, is 24.97 inches per year. The average annual air temperature is $37^{\circ} \mathrm{F}$. The summer consists of approximately 109 frost-free days and the seasonal temperature varies from $-36^{\circ} \mathrm{F}$ in the winter to $91^{\circ} \mathrm{F}$ in the summer.

In 1992, the year research plots were established at Eveleth Mines, 24.79 inches of precipitation was recorded at Hibbing. Approximately 75 percent of the annual precipitation occurred during May through September. A high temperature of $88^{\circ} \mathrm{F}$ occurred on August 9, 1992 and a low temperature of $-32^{\circ} \mathrm{F}$ occurred on December 26,1992 . The average temperature from May through September was $56^{\circ} \mathrm{F}$.

In 1993, a total of 32.43 inches of precipitation was recorded at Hibbing, which is 7.46 inches above normal. Approximately 73. percent of the annual precipitation occurred during May through September 1992. The average temperature from May through September was $56^{\circ} \mathrm{F}$, approximately the same average temperature recorded in 1992 during this period. In general, the weather in 1993 can be characterized as cooler and wetter than normal.

\section{EXPERIMENTAL DESIGN}

In May 1992, research plots (unbalanced factorial experiments) were established at Eveleth Mines arranged in a completely randomized block design with three replications (Figure 1). The experimental design "originally" included five levels of de-inking residue, three levels of fertilization, and two vegetation combinations. The original design is described below, followed by a description of changes made to the original design. 
The levels of de-inking residue evaluated were $0,10,20,40$, and 80 dry tons per acre. Inorganic fertilizer was initially applied at 0,200 , and $400 \mathrm{lb} /$ per acre of granular diammonium phosphate, which has a guaranteed analysis of 18-46-0. The fertilizer rate of $400 \mathrm{lb} / \mathrm{acre}$ of $18-$ 46-0 was selected because this level of fertilization is routinely used in the re-vegetation of coarse tailings in northern Minnesota (Norland, Veith, and Dewar, 1991). Furthermore, one-half the fertilizer rate, $200 \mathrm{lb}$ /acre of $18-46-0$, was included because this level of fertilization was being evaluated by the Bureau of Mines on adjacent research plots. On some plots, no fertilizer was applied to test the effects of de-inking residue, alone, on vegetative establishment and growth.

The location of original treatments were randomly assigned to each 2.5 meter by 4.0 meter test plot (Figures 2 to 4). Control plots were also established within each replication (block). The control plots originally consisted of plots without de-inking residue or fertilizer; plots without de-inking residue and $200 \mathrm{lb} /$ acre of 18-46-0; and plots without de-inking residue and $400 \mathrm{lb}$ of 18-46-0.

On July 24, 1992, additional fertilizer was applied to the south half of each fertilized plot because poor plant growth was observed. The amount of nitrogen fertilizer originally applied was based partially on the assumption that the residue had a carbon:nitrogen $(\mathrm{C}: \mathrm{N})$ ratio of $80: 1$. The actual C: $N$ ratio of de-inking residue used on the plots was 123:1. It was suspected at that time that the less than expected plant growth could be due to a lack of nitrogen, and to a lesser degree, phosphorus.

On plots that were initially treated with $200 \mathrm{lb} /$ acre of $18-46-0$, additional fertilizer was applied at a rate of $44 \mathrm{lb} /$ acre of actual nitrogen using the commercial fertilizers 37-0-0 and 40-0-0. An additional $88 \mathrm{lb} /$ acre of actual $\mathrm{P}_{2} \mathrm{O}_{5}$ was applied using the fertilizer 0-46-0. Total application rates of $80 \mathrm{lb} /$ acre of actual nitrogen and $180 \mathrm{lb} /$ acre of actual $\mathrm{P}_{2} \mathrm{O}_{5}$ were applied to the south half of each plot initially fertilized with $200 \mathrm{lb} /$ acre of 18-46-0. On plots originally fertilized with $400 \mathrm{lb} /$ acre of 18-46-0, total application rates of $160 \mathrm{lb} /$ acre of actual nitrogen and 359 $\mathrm{lb} /$ acre of actual $\mathrm{P}_{2} \mathrm{O}_{5}$ were applied. Subsequent sampling and vegetative measurements were completed on all divided plots after July 24, 1992.

\section{SPECIES SELECTION AND RATES}

Plant species and associated seeding rates used to establish research plots are shown in Table 1. Two categories of plant species were evaluated in this study; introduced and native species. The species classified as introduced species are routinely used in the re-vegetation of coarse tailings in northern Minnesota. Furthermore, the introduced species were used on the adjacent Bureau of Mines plots. The introduced species included smooth bromegrass (Bromus inermis), red fescue (Festuca rubra), perennial ryegrass (Lolium perenne), alfalfa (Medicago sativa), and buckwheat (Fagopyrum esculentum).

Native species were evaluated in this study because introduced species have not been consistently successful in achieving the regulatory requirement of 90 percent vegetative cover. Furthermore, native species adapt to harsh site conditions, although they are slower to establish above-ground plant growth in comparison to introduced species. The native species evaluated in this study 
included big bluestem (Andropogon gerardii), little bluestem (Schizachyrium scoparium), kalm's brome (Bromus kalmii), Canada wild rye (Elymus canadensis), and bush clover (Lespedeza capitata).

\section{PLOT ESTABLISHMENT}

Initially, 108 research plots were established at Eveleth Mines in May 1992. The moisture content of de-inking residue was determined to calculate the amount of wet residue to apply per plot. The wet residue was weighed in the field to determine the amount of residue to apply at the experimental rates of $10,20,40$, and 80 dry tons per acre.

After spreading de-inking residue uniformly onto individual $10 \mathrm{~m}^{2}$ ( 2.5 meter by 4.0 meter) plots with a hand rake, fertilizer was weighed out and spread onto the surface of each plot. De-inking residue and fertilizer were incorporated into coarse tailings by rototilling to a depth of 6 inches. The control plots were also rototilled to a depth of 6 inches.

After rototilling, the plots were hand raked as smooth as possible for seeding. The seed was spread onto the surface by hand at the selected seeding rates. The plots were then lightly hand raked to incorporate seed into coarse tailings and tailings/residue amended plots. The plots were mulched with hay at a rate of 2 tons per acre. Plastic netting was placed over the mulch and staked into the coarse tailings to hold the mulch in place. A 6 foot high fence was erected around the perimeter of the study area to prevent wildlife from disturbing the plots.

The additional fertilizer applied to the south half of each plot on July 24,1992 was uniformly broadcast onto the plots without incorporation of the fertilizer into the tailings.

\section{LYSIMETER INSTALLATION, SAMPLING AND ANALYSIS}

Nine suction-cup lysimeters were installed using a 4-inch bucket auger to a depth of 48 inches below the surface. Lysimeters were installed to monitor changes in sub-surface water quality in the unsaturated zone. Three lysimeters were installed within each block (replication), on plots that received 0,200 and $400 \mathrm{lb} /$ acre of $18-46-0$ and on plots that received 0,20 , and 80 dry tons per acre of de-inking residue. Since the lysimeters were installed on the north half of plots, these sub-plots did not receive additional fertilizer on July 24,1992 . The location of lysimeters are identified on the mineland reclamation plot plans in Figures 2 through 4.

Approximately 4 inches of a silica flour slurry was placed in the bottom of each borehole and the porous ceramic cup on each lysimeter was embedded into the silica flour slurry. The borehole was then backfilled with on-site coarse tailings in lifts of approximately 6 inches and compacted using a small diameter rod. Coarse tailings were placed within the annular space from the top of the silica flour mixture to the ground surface. The top of each lysimeter was extended 4-6 inches above the surface.

Water samples were collected from lysimeters monthly during June, July, August, and September 1992 and April, June, August, and September 1993. Samples were collected using a hand pump and small diameter tube. Samples were kept cool and shipped to the Department 
of Soil Science Research Analytical Laboratory (RAL), University of Minnesota, for chemical analysis. The analysis included the determination for calcium, magnesium, sodium, phosphorus, potassium, iron, aluminum, manganese, copper, zinc, boron, cadmium, chromium, nickel, lead, vanadium, beryllium, nitrate nitrogen, chloride, and sulfate. The determination for nitratenitrogen began in September 1992.

\section{VEGETATIVE COVER DETERMINATIONS, PLANT SAMPLING AND ANALYSIS}

A cover-point optical projection device was used to determine percent vegetative cover in July and September 1992 and in July and September 1993. The cover-point optical projection device was mounted on a one meter long bar that had ten stops along the bar at $10 \mathrm{~cm}$ intervals. One end of the bar was attached to a photographic tripod and the other end was attached to an adjustable support rod. The percent vegetative cover was determined by looking through the eyepiece and recording hits and misses of vegetation using the fine cross hairs within the optics for each of 10 sample points across the bar. Three transects were made across each plot for a total of 30 point-intercept cover sampling points per plot. Since additional fertilizer was applied to the south half of each fertilized plot on July 24,1992 , three transects were made on both the north and south half of each plot.

Plant samples were collected for chemical analysis from plots in September/October of 1992 and 1993. Many of the plots had minimal amounts of above-ground plant growth in the fall of 1992 since the plots were established only 4 months earlier. A limited number of plant samples were collected in 1992 for chemical analysis. The plants sampled in 1992 included alfalfa and grasses from plots seeded with the introduced species mix. There was insufficient above-ground vegetative growth on plots seeded with native species for plant sampling and analysis in 1992 . Alfalfa and grass samples were collected in 1992 by randomly clipping the vegetation at the surface from each of the plots sampled. Vegetation samples were composited, based upon treatments, into 15 composite samples. The plant samples were dried at $65^{\circ} \mathrm{C}$ in a forced air drier, and ground with a Wiley-mill to pass through a 20 -mesh screen, and submitted to the University of Minnesota (RAL) for chemical analysis.

In September 1993, plant samples were collected from each plot using two circular $0.1 \mathrm{~m}^{2}$ subplots. The sub-plots were located in the same position on each plot. This sampling method was selected so that sampling for plant biomass could be done in subsequent years. All above-ground plant materials within the $0.1 \mathrm{~m}^{2}$ sub-plots were clipped at the ground surface, bagged and returned to the laboratory for species identification. The plant samples were then dried, ground, and submitted for chemical analysis.

\section{DE-INKING RESIDUE AND COARSE TAILINGS SAMPLING AND ANALYSIS}

De-inking residue was obtained from a paper recycling facility in Illinois. A residue from Illinois was used because the SRFI facility did not begin production until August 1993. Furthermore, it was believed that the Illinois residue would be similar to the residue expected to be produced at the SRFI facility. Five composite samples of the de-inking residue were collected prior to plot establishment. Moisture content was determined and samples were submitted for chemical analysis to the University of Minnesota (RAL). 
Coarse tailings were sampled from the study area in May 1992 before de-inking residue, fertilizer, or seed were applied. The locations for sampling coarse tailings were randomly selected and samples of tailings were obtained using a 3-inch diameter bucket auger to a depth of 6 inches. Five composite samples of coarse tailings were submitted to the University of Minnesota (RAL) for chemical analysis.

After treatments were applied to plots, the coarse tailings were sampled at four different times; in May and September 1992 and in June and September 1993. One sample of coarse tailings was collected from each plot to a depth of 6 inches. Tailings samples were then composited, by replication, for each treatment and submitted to the University of Minnesota (RAL) for chemical analysis. In May 1992, thirty-six composite tailings samples were collected, while in September 1992 and in June and September 1993, seventy-two composite tailings samples were collected for analysis, because of the addition of fertilizer applied to half of each of the original fertilized plots.

\section{RESULTS AND DISCUSSION}

\section{COARSE TALINGS CHARACTERIZATION}

The chemical properties of coarse tailings at Eveleth Mines, prior to the application of de-inking residue and fertilizer, are summarized in Table 2 . The analysis of the tailings, before treatments were applied, documents some inherent poor chemical characteristics that could impact the establishment and growth of vegetation at Eveleth Mines.

There are seventeen nutrients essential for plant growth. The elements carbon, oxygen and hydrogen are derived by plants from air or water. Six nutrients derived from soils, called macronutrients, are required by plants in relatively large quantities. The macronutrients include nitrogen, phosphorus, potassium, calcium, magnesium, and sulfur. Eight nutrients are required by plants in small quantities and are called micronutrients, including iron, manganese, boron, molybdenum, copper, zinc, chlorine, and cobalt.

The $\mathrm{pH}$ of a growing media is important because it affects the availability of plant nutrients and populations of soil microorganisms. The average $\mathrm{pH}$ of the coarse tailings was 8.7 , which is considered moderately alkaline. On adjacent Bureau of Mines plots, the average pH was 8.2 (Norland, Veith, and Dewar, 1991). The optimum pH range for most plant species occur in the near neutral range, between 6.0 to 7.0. Within this range, the availability of nutrients and the activity of beneficial microorganisms is generally highest. Under alkaline conditions, plant nutrient availability decreases for both macronutrients and micronutrients.

Soluble salts, a measure of major dissolved inorganic solutes, is estimated by determining electrical conductivity. A mean conductivity of $0.5 \mathrm{mmhos} / \mathrm{cm}$ was measured, which indicates that the tailings do not contain soluble salt concentrations high enough to impair plant growth.

The tailings contain 0.96 percent organic matter and 0.98 percent total organic carbon. Although organic matter and total organic carbon were higher in the study area as compared to levels on adjacent Bureau of Mines plots, the levels of organic matter and total organic carbon are substantially less than mineral soils common to northern Minnesota. Organic matter is important 
because it is a source of nutrients, including nitrogen, phosphorus, and sulfur, and it has a high cation exchange capacity. The lack of organic matter in coarse tailings, therefore, could limit the ability of the tailings to supply nitrogen, phosphorus, and sulfur to growing vegetation.

The cation exchange capacity (CEC) of the coarse tailings was $2.0 \mathrm{meq} / 100 \mathrm{~g}$. The CEC is the total amount of exchangeable cations that a material can adsorb. Cations are positively charged ions including calcium, magnesium, potassium, sodium, ammonium, and hydrogen. Sandy soils have low CEC's whereas soils with a high organic matter content have high CEC's. Humus, or well decomposed organic matter, typically has a high CEC (200 meq/100 g). Finer textured soils, depending upon the type of clay mineral present, tend to have higher CEC's than sandy textured soils. Coarse tailings have a low CEC because of its mineral composition (high silica content), large particle size, lack of clay and silt sized particles, and lack of soil organic matter or humus. The low CEC and organic matter content of coarse tailings severely limits the ability of the tailings to retain both available water and nutrients for plant growth.

The level of nitrogen measured in coarse tailings was low, as measured by three forms of nitrogen; total organic (Kjeldahl) nitrogen, nitrate-nitrogen, and ammonium-nitrogen. The low nitrogen content of coarse tailings is directly related to its low organic matter level. The total organic (Kjeldahl) nitrogen level was 0.01 percent, the nitrate-nitrogen level was $0.6 \mathrm{mg} / \mathrm{kg}$, and ammonium-nitrogen was $6.4 \mathrm{mg} / \mathrm{kg}$. The levels of nitrogen in the tailings at this location were similar to the nitrogen levels measured on adjacent Bureau of Mines plots, with the exception of ammonium-nitrogen, where a mean ammonium-nitrogen concentration of only $0.2 \mathrm{mg} / \mathrm{kg}$ was reported (Norland, Veith, Dewar, 1991).

The concentrations of selected elements in coarse tailings were determined as both the extractable and total forms. In general, the extractable form of an element is determined by extracting a sample with a weak acid solution(s). The level of an element(s) in the extracting solution is then determined. The extractable concentration of an element or compound would be that fraction considered readily, or potentially, available to a plant. The total concentration of an element is determined by complete dissolution of a sample in a strong acid and/or oxidizing agent. The total concentration of an element is considered the total amount of that element in the sample.

The coarse tailings contained very low levels of extractable phosphorus, $1.4 \mathrm{mg} / \mathrm{kg}$, using the Olsen method. The mean concentration of extractable phosphorus measured on adjacent Bureau of Mines plots was $3 \mathrm{mg} / \mathrm{kg}$, using the Bray-1 method (Norland, Veith, Dewar, 1991). The total concentration of potassium in tailings suggests that this macronutrient is at a high level. The tailings had a mean concentration of $13 \mathrm{mg} / \mathrm{kg}$ of sulfate-sulfur, the form of sulfur considered available to plants. The mean sulfate level on adjacent Bureau of Mines plots was slightly lower, $3 \mathrm{mg} / \mathrm{kg}$ of sulfate (Norland, Veith, Dewar, 1991). Coarse tailing have insufficient levels of phosphorus and sulfur for plant growth but an adequate level of potassium. Based on these results, the addition of phosphorus and sulfur as a fertilizer, or supplied by an organic amendment, is needed for successful plant establishment. 
The extractable micronutrient levels in the coarse tailings were low, as compared to levels found in common mineral soils in Minnesota. The level of iron was $62.74 \mathrm{mg} / \mathrm{kg}$, copper was 0.14 $\mathrm{mg} / \mathrm{kg}$, zinc was $0.13 \mathrm{mg} / \mathrm{kg}$, manganese was $16.11 \mathrm{mg} / \mathrm{kg}$, and boron was $0.01 \mathrm{mg} / \mathrm{kg}$. The level of extractable cadmium was less than the detection limit of $0.02 \mathrm{mg} / \mathrm{kg}$. Chromium was detected at concentration of $0.01 \mathrm{mg} / \mathrm{kg}$, nickel at $0.12 \mathrm{mg} / \mathrm{kg}$, and lead at $0.45 \mathrm{mg} / \mathrm{kg}$. The levels of these metals are low in comparison to levels found in typical Minnesota soils (Pierce, 1980).

In general, the results indicate that the coarse tailing are an inherently poor substrate for plant growth. The chemical properties likely to be inhibiting successful re-vegetation of coarse tailings include an alkaline $\mathrm{pH}$, low organic matter and carbon content, low cation exchange capacity and available water holding capacity, and low macronutrient and micronutrient levels.

\section{DE-INKING RESWUE CHARACTERIZATION}

The de-inking residue analytical results are presented in Table 3. At the time of analysis, the residue had a moisture content of 67.3 percent and a solids content of 32.7 percent. The results indicate that approximately $1,346 \mathrm{lb}$ of water and $654 \mathrm{lb}$ of dry matter are contained in each ton of this processed residue.

The $\mathrm{pH}$ of the residue was 8.2 , which is considered moderately alkaline. The total organic carbon content of the residue was 25.84 percent. An estimate of the organic matter content, 44.5 percent, was determined by multiplying the total organic carbon by the Van Bemmelin factor of 1.724 (Nelson and Sommers, 1982). This factor assumes that organic matter contains 58 percent carbon, although the carbon level in organic matter is variable.

The nitrogen content of de-inking residue was low, as determined by two forms of nitrogen in the residue; total organic (Kjeldahl) nitrogen and nitrate nitrogen. Total organic (Kjeldahl) nitrogen content was 0.21 percent while nitrate-nitrogen was only $1.44 \mathrm{mg} / \mathrm{kg}$.

The organic carbon content and total organic (Kjeldahl) nitrogen were used to determine the carbon to nitrogen $(C: N)$ ratio of de-inking residue, which had an average $C: N$ ratio of 123:1. The $\mathrm{C}: \mathrm{N}$ ratio is a simple way of expressing the relative proportion of carbon to nitrogen in a material, since the $C: N$ ratio of organic materials is quite variable. Materials with small $C: N$ ratios (10:1) are relatively high in nitrogen, while large ratios (80:1) indicate low nitrogen levels. For example, agricultural soils typically have a $C: N$ ratio of $10: 1$, sweet clover has a $C: N$ ratio of $12: 1$, straw has a $C: N$ ratio of $80: 1$, while sawdust (wood) has a $C: N$ ratio of 400:1.

The high $\mathrm{C}: \mathrm{N}$ ratio of de-inking residue, 123:1, indicates that the residue has a low nitrogen content relative to its carbon content. Typically, when the $C: N$ ratio is less than $15: 1$ to $20: 1$, there is enough nitrogen in the material to satisfy the nitrogen requirements of decomposing microorganisms. When the ratio exceeds $15: 1$ to $20: 1$, nitrogen will be temporarily tied-up by microorganisms decomposing the residue. Thus, the $\mathrm{C}: \mathrm{N}$ ratio is an indicator of the extent to which nitrogen could limit plant growth since microorganisms out-compete plants for nitrogen as organic material decomposes. If this residue was used to amend soils or tailings without a nitrogen supplement, a plant nitrogen deficiency would probably occur. 
Total carbonate content was 18.1 percent and the calcium content was 6.9 percent. Calcium carbonate, a compound removed during the re-pulping process, becomes a component of deinking residue. The addition of calcium carbonate, or lime, to an acidic soil is beneficial because it not only increases soil $\mathrm{pH}$ but supplies the nutrient, calcium, to growing vegetation.

The mean CEC of de-inking residue was $8.3 \mathrm{meq} / 100 \mathrm{~g}$. Kaolinite, a type of clay commonly used in the production of paper, has a CEC of approximately $8 \mathrm{meq} / 100 \mathrm{~g}$. The low CEC of the de-inking residue is likely due to the level of kaolinite clay and wood fiber removed from waste paper in the re-pulping process.

The levels of total phosphorus $(225.7 \mathrm{mg} / \mathrm{kg}$ or 0.02 percent), total potassium $(47.73 \mathrm{mg} / \mathrm{kg}$ or 0.005 percent) and total organic (Kjeldahl) nitrogen ( 0.21 percent) in de-inking residue are low. Based on this analysis, de-inking residue would not provide a significant amount of macronutrients to vegetation when applied to coarse tailings.

The concentrations of cadmium, chromium, copper, lead, nickel, and zinc in de-inking residue were compared to the "ceiling concentrations" identified in the Environmental Protection Agency's (EPA) Standards for the Use or Disposal of Sewage Sludge (EPA, 1993). The rules state that "sewage sludge sold or given away in a bag or other container shall not be applied to land if the concentration of any pollutant in the sewage sludge exceeds the ceiling concentration for the pollutants listed in Table $1 "$ ". The ceiling concentrations, and mean concentrations contained in de-inking residue, are as follows:

\begin{tabular}{lcc}
\hline Metal & $\begin{array}{c}\text { EPA Ceiling Concentration } \\
(\mathrm{mg} / \mathrm{kg})\end{array}$ & $\begin{array}{c}\text { De-inking Residue } \\
(\mathrm{mg} / \mathrm{kg})\end{array}$ \\
\hline Cadmium & 85 & $\ldots$ \\
Chromium & 3000 & 0.20 \\
Copper & 4300 & 4.89 \\
Lead & 840 & 3.12 \\
Nickel & 420 & 2.84 \\
Zinc & 7500 & 1.28 \\
& & 38.67 \\
\hline
\end{tabular}

The analytical results indicate that the concentration of these metals in de-inking residue is very low. Metal concentrations in de-inking residue are less than 1.0 percent of the ceiling concentrations allowed in municipal sewage sludge that can be land applied.

\section{COARSE TAILINGS AMENDED WITH RESIDUE CHARACTERIZATION}

The effects of de-inking residue on chemical properties of coarse tailings are discussed in this section of the report. As previously described, the tailings were sampled four times after plot establishment and composite samples were submitted for chemical analysis. The values reported in this section generally represent a single analysis from a composite sample, combined by treatment, from samples collected in the fall of 1992 and 1993. The complete data set for this 
analysis is tabulated in Appendix A. This section describes the effects de-inking residue had on coarse tailings in 1992 and 1993, with and without the addition of commercial fertilizer.

\section{TREATMENTS WITHOUT FERTILIZER}

The effects of de-inking residue on coarse tailings, without the addition of fertilizer, on plots established with introduced and native species are shown in Table 4 and Table 5 , respectively.

De-inking residue did not change the $\mathrm{pH}$ of coarse tailings in 1992 and 1993 on the introduced or native plots, although the $\mathrm{pH}$ did increase slightly by 0.1 to $0.3 \mathrm{pH}$ units. The $\mathrm{pH}$ increased from 8.2 to 8.5 on control plots (no residue or fertilizer) established with introduced species and from 8.3 to 8.6 on control plots established with native species. On residue amended plots, there was either no change, or a slight increase $(0.2 \mathrm{pH}$ units) in $\mathrm{pH}$, between the fall of 1992 and 1993.

The electrical conductivity (EC), a measure of soluble salt concentration, was low for coarse tailings amended with de-inking residue. The electrical conductivity ranged between 0.1 and 0.2 mmhos $/ \mathrm{cm}$. Electrical conductivity did not appreciably change due to the addition of de-inking residue to coarse tailings during this time.

Total organic nitrogen was generally less than 0.01 percent, although a total organic nitrogen content of 0.04 percent was detected in 1992 at a residue rate of 80 ton/acre, native species plot. Total organic carbon was generally between 0.99 and 1.47 percent, although the highest total organic carbon, 3.06 percent, was measured in 1992 at a residue rate of 80 ton/acre, native species plot. The $C: N$ ratio on control plots and on residue amended plots were high in 1992 and 1993, ranging between $104: 1$ and 403:1 on control plots and between 75:1 and 397:1 on residue amended plots. In general, the $\mathrm{C}: \mathrm{N}$ ratio of coarse tailings and of tailings amended with residue decreased between 1992 and 1993 on all but two plots. These plots included the residue amended plot at 40 ton/acre, introduced species, and on the residue amended plot at 80 ton/acre, native species.

Nitrate-nitrogen and ammonium-nitrogen levels were low in the control tailings and in the tailings amended with residue in 1992 and 1993. Nitrate-nitrogen was generally less than 1.0 $\mathrm{mg} / \mathrm{kg}$ on both control and residue amended plots. Two plots had nitrate-nitrogen levels higher than $1.0 \mathrm{mg} / \mathrm{kg}$, including the control plot and the residue amended plot at $80 \mathrm{ton} /$ acre, native species in 1992. Nitrate-nitrogen levels decreased for each treatment between 1992 and 1993. Ammonium-nitrogen levels were similar among the control and residue treatments in 1992 and 1993, with ammonium-nitrogen less than $0.3 \mathrm{mg} / \mathrm{kg}$ on all but two plots. The two highest ammonium-nitrogen levels, $1.1 \mathrm{mg} / \mathrm{kg}$ and $3.2 \mathrm{mg} / \mathrm{kg}$, were measured on residue amended plots at 10 and 40 ton/acre in 1992.

Organic matter content generally ranged between 0.8 and 1.1 percent, although a high organic matter content of 6.2 percent occurred on the 80 ton/acre residue amended plot, native species in 1992. The cation exchange capacity on control plots and on residue amended plots were low, ranging between 1.7 and $2.1 \mathrm{meq} / 100 \mathrm{~g}$. It does not appear that de-inking residue, applied at these rates without fertilizer, benefitted coarse tailings through an improvement in cation exchange capacity. 
Chloride levels on the control plots and residue amended plots ranged between $0.4 \mathrm{mg} / \mathrm{kg}$ and $13.2 \mathrm{mg} / \mathrm{kg}$. Chloride levels measured in coarse tailings, with and without residue, decreased over time for all treatments. The highest chloride levels, $6.3 \mathrm{mg} / \mathrm{kg}$ and $13.2 \mathrm{mg} / \mathrm{kg}$, were measured in 1992 on residue amended plots at the highest residue rates, 40 and 80 ton/acre.

Available phosphorus concentrations, ranging between $1 \mathrm{mg} / \mathrm{kg}$ and $12 \mathrm{mg} / \mathrm{kg}$, were very low to high on the control and residue amended plots (Rehm, Schmitt, and Munter, 1993). Phosphorus levels were typically less than $4 \mathrm{mg} / \mathrm{kg}$, although phosphorus levels of $8 \mathrm{mg} / \mathrm{kg}$ and $12 \mathrm{mg} / \mathrm{kg}$ were measured on three residue amended plots in 1992. Although phosphorus levels were higher on these three plots, de-inking residue is not a major source of phosphorus. Phosphorus levels in residue amended tailings decreased over time.

Sulfate-sulfur in coarse tailings was generally less than $1 \mathrm{mg} / \mathrm{kg}$ on residue amended plots, although a sulfate-sulfur level of $24 \mathrm{mg} / \mathrm{kg}$ was measured on the residue amended plot at 80 ton/acre in 1992. In 1992, the control plots with both introduced and native species had higher sulfate-sulfur levels on all but one residue amended plot.

The levels of extractable metals in tailings amended with residue did not appear to change, with the exception of residue applied at $80 \mathrm{ton} / \mathrm{acre}$. At $80 \mathrm{ton} / \mathrm{acre}$, the levels of iron, manganese, and copper in the tailings on the plot seeded with native species, were higher than all other plots in 1992. These metals were not elevated on introduced species plot at a residue rate of 80 ton/acre in 1992, although lead was slightly elevated on this plot. The levels of extractable cadmium, chromium, copper, nickel, lead, and zinc in residue amended tailings were less than those found in selected Minnesota soils (Pierce, 1980).

Based on this data, it appears that the short-term effects of de-inking residue on selected coarse tailings properties, without the addition of fertilizer, are minimal. De-inking residue did not change the $\mathrm{pH}$ or electrical conductivity of coarse tailings. De-inking residue had a minimal impact on organic nitrogen, organic carbon, nitrate- and ammonium-nitrogen, phosphorus, organic matter, and CEC of tailings, without the addition of fertilizer. The highest chloride levels in tailings were measured on plots amended with residue at the highest rates. Higher levels of metals found at a residue rate of 80 ton/acre is likely due to a sample dominated by residue because, at this rate, the surface is largely covered with residue. High levels of organic carbon, organic matter and chlorides in this sample indicate the sample had a high amount of de-inking residue.

\section{TREATMENTS WITH FERTILIZER AT THE HIGHEST RATE}

The effects of de-inking residue on coarse tailings, treated with fertilizer, are presented in Table 6 for introduced species and in Table 7 for native species for the fall of 1992 and 1993. Only plots fertilized at the highest rate $\left(160 \mathrm{lb} /\right.$ acre $\mathrm{N}$ and $\left.359 \mathrm{lb} / \mathrm{acre} \mathrm{P}_{2} \mathrm{O}_{5}\right)$ are shown in these two tables.

De-inking residue did not change the $\mathrm{pH}$ of coarse tailings, fertilized at the highest rate, in 1992 and 1993 on the introduced or native plots. The pH ranged between 8.2 and 8.4 on control plots (fertilized with no residue) and between 8.1 and 8.4 on residue amended plots. 
The electrical conductivity of coarse tailings, amended with both residue and fertilizer, was low and ranged between 0.1 and $0.3 \mathrm{mmhos} / \mathrm{cm}$. Electrical conductivity did not change appreciably due to the addition of de-inking residue and fertilizer applied at the highest rate to coarse tailings during this time.

Total organic nitrogen was generally less than 0.01 percent, although a total organic nitrogen content of 0.05 percent was detected in 1992 at a residue rate of 80 ton/acre, native species plot. Total organic carbon was generally between 0.82 and 1.75 percent, although the highest total organic carbon levels, 3.08 percent and 3.11 percent, were measured in 1992 at a residue rate of 80 ton/acre. The $\mathrm{C}: \mathrm{N}$ ratio on fertilized control plots and on residue amended plots were high in 1992 and 1993, ranging from 106:1 to $452: 1$ on control plots and from 69:1 to $258: 1$ on residue amended plots. The $\mathrm{C}: \mathrm{N}$ ratio of coarse tailings, without treatments, decreased between the years 1992 and 1993. On residue and fertilizer amended plots, the C:N ratio increased between 1992 and 1993 on six of eight plots.

Nitrate-nitrogen and ammonium-nitrogen levels were low in the fertilized control tailings and varied somewhat in tailings amended with residue and fertilizer in 1992 and 1993. Nitratenitrogen was less than $0.4 \mathrm{mg} / \mathrm{kg}$ on control plots. On the residue and fertilizer amended plots, nitrate-nitrogen was generally less than $0.4 \mathrm{mg} / \mathrm{kg}$, except on two plots with introduced plant species that were fertilized and amended with residue at 10 and 20 ton/acre. Perhaps the alfalfa, which fixes atmospheric nitrogen, contributed somewhat to these two higher nitrogen levels where $2.2 \mathrm{mg} / \mathrm{kg}$ and $4.2 \mathrm{mg} / \mathrm{kg}$ of nitrate-nitrogen were measured. Ammonium-nitrogen levels on control plots ranged between 0.1 and $0.5 \mathrm{mg} / \mathrm{kg}$. On the residue and fertilizer amended plots, ammonium-nitrogen ranged between 0.1 and $2.2 \mathrm{mg} / \mathrm{kg}$. The two highest ammonium-nitrogen levels, $1.7 \mathrm{mg} / \mathrm{kg}$ and $2.2 \mathrm{mg} / \mathrm{kg}$, occurred in 1992 on residue amended plots at 20 and 80 ton/acre.

Organic matter content ranged between 0.9 and 1.0 percent on fertilized control plots and from 0.7 to 4.5 percent on residue and fertilizer amended plots. The high organic matter content of 4.5 percent occurred on the residue amended plot at 80 ton/acre with fertilizer in 1992, native species.

The cation exchange capacity on fertilized control plots ranged between 1.8 and $1.9 \mathrm{meq} / 100 \mathrm{~g}$. On residue and fertilizer amended plots, the cation exchange capacity ranged between 1.7 and $2.3 \mathrm{meq} / 100 \mathrm{~g}$. It does not appear that de-inking residue, with fertilizer, benefitted coarse tailings through an improvement in cation exchange capacity in 1992-1993.

Chloride levels ranged between $0.3 \mathrm{mg} / \mathrm{kg}$ and $2.7 \mathrm{mg} / \mathrm{kg}$ on fertilized control plots. On residue amended plots with fertilizer, chloride ranged between $0.1 \mathrm{mg} / \mathrm{kg}$ and $11.6 \mathrm{mg} / \mathrm{kg}$. Chloride levels decreased over time for 7 of 10 treatments. The highest chloride levels, $10.1 \mathrm{mg} / \mathrm{kg}$ and $11.6 \mathrm{mg} / \mathrm{kg}$, were measured in 1992 on residue amended plots at 80 ton/acre.

The levels of available phosphorus were higher, as expected, on plots fertilized with commercial phosphorus fertilizer. On fertilized control plots in 1992, extractable phosphorus was $14 \mathrm{mg} / \mathrm{kg}$ and $21 \mathrm{mg} / \mathrm{kg}$ in 1992, which are considered high and very high phosphorus levels for plant growth (Rehm, Schmitt, and Munter, 1993). On fertilized control plots in 1993, available 
phosphorus levels decreased from $14 \mathrm{mg} / \mathrm{kg}$ and $21 \mathrm{mg} / \mathrm{kg}$ to $3 \mathrm{mg} / \mathrm{kg}$ and $4 \mathrm{mg} / \mathrm{kg}$, considered very low to low levels of phosphorus for plant growth. On fertilized residue amended plots, extractable phosphorus ranged between 14 and $35 \mathrm{mg} / \mathrm{kg}$ in 1992 considered high to very high phosphorus levels for plant growth. In 1993, phosphorus levels ranged between $6 \mathrm{mg} / \mathrm{kg}$ and $17 \mathrm{mg} / \mathrm{kg}$ on fertilized residue amended plots, considered low to very high levels for plant growth. The levels of available phosphorus decreased between 1992 and 1993 on all, but one fertilized residue amended plot. It appears phosphorus was either being removed from the tailings by vegetation during the 1993 growing season or being "fixed" because of alkaline $\mathrm{pH}$ conditions. Phosphorus levels measured in the fall of 1993, which ranged between $6 \mathrm{mg} / \mathrm{kg}$ and $17 \mathrm{mg} / \mathrm{kg}$, are considered low to very high levels for plant growth.

Sulfate-sulfur in tailings treated with fertilizer was higher in 1992 as compared to levels measured in 1993. On residue and fertilizer amended plots, sulfate-sulfur was generally less than $4 \mathrm{mg} / \mathrm{kg}$, except on three residue amended plots. The highest sulfate-sulfur levels occurred in 1992 on plots amended with residue at 80 ton/acre.

The levels of extractable metals in tailings, amended with residue and fertilizer, did not appear to change appreciably, with the exception of plots treated with residue at 80 ton/acre. On these plots, the levels of iron, manganese, copper, zinc, nickel, and lead were generally higher than levels found in tailings on other plots in 1992. The levels of extractable cadmium and chromium in residue amended tailings, with fertilizer, were low and less than those found in selected Minnesota soils (Pierce, 1980).

It appears that the short-term effects of de-inking residue on coarse tailings, fertilized at the high rate, may be influenced to a greater degree by commercial fertilizer than de-inking residue. Few changes were observed in $\mathrm{pH}$, electrical conductivity, organic matter, and CEC. Chloride levels were higher on residue amended plots, especially at 80 ton/acre. The level of phosphorus was higher on fertilized plots. Extractable metals in tailings, amended with residue at 80 ton/acre were elevated, but were less than levels found in typical Minnesota soils.

\section{LYSIMETER ANALYSIS}

The effects of de-inking residue, with and without commercial fertilizer, on sub-surface water quality in the unsaturated zone was evaluated using suction cup lysimeters at a depth of 4 feet below the surface.

The concentrations of selected anions including boron, chloride, nitrate-nitrogen, and sulfatesulfur in sub-surface water are of interest because these negatively charged compounds move readily with water that percolates from the surface to lower depths in coarse tailings. The discussion in this report is limited to an evaluation of the impact de-inking residue may have on sub-surface water quality for boron, chloride, nitrate-nitrogen, and sulfate-sulfur during the monitoring period 1992-1993. The complete set of lysimeter analyses are presented in Appendix $B$ for each of eight sampling dates. 
The sources of the anions identified above could come from the coarse tailings, commercial fertilizer, de-inking residue, plants that fix nitrogen including alfalfa, or atmospheric deposition. As previously identified, the tailings had a mean concentration of $17.99 \mathrm{mg} / \mathrm{kg}$ total boron (and $0.1 \mathrm{mg} / \mathrm{kg}$ of extractable boron), $0.6 \mathrm{mg} / \mathrm{kg}$ nitrate-nitrogen and $13 \mathrm{mg} / \mathrm{kg}$ sulfate-sulfur. Deinking residue had a mean concentration of $1.56 \mathrm{mg} / \mathrm{kg}$ total boron, $287.6 \mathrm{mg} / \mathrm{kg}$ chloride, 1.4 $\mathrm{mg} / \mathrm{kg}$ nitrate-nitrogen and $24.8 \mathrm{mg} / \mathrm{kg}$ sulfate-sulfur. The fertilizer contained significant levels of nitrogen and phosphorus but fertilizer can also contain trace amounts of other elements.

The Minnesota Department of Health (MDH) has established drinking water standards for these constituents (MDH, 1991). The standards, called Maximum Contaminant Levels (MCL's) for secondary contaminants include numerical limits for boron, chloride, nitrate-nitrogen, and sulfate-sulfur. The standards for these four constituents are as follows:

\begin{tabular}{cc} 
Drinking Water Standards (MCL's) \\
Compound & (mg/l) \\
\hline Boron & 0.3 \\
Chloride & 250 \\
Nitrate & 10 \\
Sulfate & 250 \\
\hline
\end{tabular}

The analytical results for water samples collected from lysimeters will be compared to the drinking water standards for boron, chloride, nitrate-nitrogen and sulfate-sulfur.

\section{BORON}

The water analysis for boron, grouped by fertilizer level, during June 1992-September 1993 is presented in Figures 5, 6 and 7. As previously identified, the drinking water standard (MCL) for boron is $0.3 \mathrm{mg} / 1$.

Without the addition of fertilizer, boron levels in sub-surface water ranged from 0.089 to 0.29 $\mathrm{mg} / \mathrm{l}$ (Figure 5). The pattern of boron concentrations in sub-surface water were similar for each of the residue rates, without fertilizer, during this monitoring period. The highest boron level measured during this monitoring period, $0.29 \mathrm{mg} / 1$, was measured in August 1992 on a control plot (no fertilizer or residue). Boron levels were higher in 1992 as compared to 1993 for both the control and residue amended plot at 20 ton/acre.

At a fertilizer level of $36 \mathrm{lb} /$ acre $\mathrm{N}$ and $92 \mathrm{lb} /$ acre $\mathrm{P}_{2} \mathrm{O}_{5}(200 \mathrm{lb} /$ acre 18-46-0), boron ranged from $0.056 \mathrm{mg} / \mathrm{l}$ to $0.247 \mathrm{mg} / \mathrm{l}$ (Figure 6). Boron levels were higher in 1992 as compared to 1993 for the same month each year. The highest boron levels, at this fertilizer level, were measured on residue amended tailings at 80 ton/acre. The lowest boron concentrations, at this fertilizer level, generally occurred in sub-surface water on tailings without de-inking residue. 
At a fertilizer level of $72 \mathrm{lb} /$ acre $\mathrm{N}$ and $184 \mathrm{lb} /$ acre $\mathrm{P}_{2} \mathrm{O}_{5}(400 \mathrm{lb} /$ acre 18-46-0), boron in subsurface water ranged from $0.053 \mathrm{mg} / 1$ to $0.25 \mathrm{mg} / \mathrm{l}$ (Figure 7). The highest boron levels in subsurface water from June 1992 through September 1993 occurred on the plot without residue at this fertilizer level. The lowest boron levels in sub-surface water during this monitoring period generally occurred on tailings amended with residue at 20 ton/acre, at this fertilizer level.

Based on this data, de-inking residue did not appear to affect the level of boron in sub-surface water at a depth of 4 feet. The highest boron level in sub-surface water was measured on a control plot. Elevated boron levels were measured in sub-surface water in tailings not amended with de-inking residue in 1992 and 1993. The level of boron in sub-surface water did not exceed the drinking water standard during this monitoring period.

\section{CHLORIDE}

The lysimeter analysis for chloride, grouped by fertilizer level, from June 92 through September 93 is presented in Figures 8, 9 and 10. The drinking water standard (MCL) for chloride is 250 $\mathrm{mg} / \mathrm{l}$.

Without the addition of fertilizer, chloride in sub-surface water ranged from $0.9 \mathrm{mg} / 1$ to 111.5 $\mathrm{mg} / \mathrm{l}$ during this monitoring period (Figure 8). In this study, the highest chloride level was measured in July 1992 on the control plot (no fertilizer or residue). At a residue rate of 20 ton/acre, chloride levels decreased over time. At residue rates of 0 and 80 ton/acre, chloride levels increased in July 1992 but decreased over time until September 1993.

At a fertilizer level of $36 \mathrm{lb} /$ acre $\mathrm{N}$ and $92 \mathrm{lb} /$ acre $\mathrm{P}_{2} \mathrm{O}_{5}(200 \mathrm{lb} / \mathrm{acre} 18-46-0)$, chloride ranged from $0.48 \mathrm{mg} / 1$ to $103.9 \mathrm{mg} / \mathrm{l}$ (Figure 9). The highest chloride levels occurred on the residue amended plot at 80 ton/acre in July 1992 through June 1993. At this fertilizer rate, chloride levels in sub-surface water on plots amended with residue at 0 and 20 ton/acre decreased over time at approximately the same rate.

At a fertilizer rate of $72 \mathrm{lb} /$ acre $\mathrm{N}$ and $184 \mathrm{lb}$ /acre $\mathrm{P}_{2} \mathrm{O}_{5}(400 \mathrm{lb} / \mathrm{acre} 18-46-0)$, chloride ranged from $0.38 \mathrm{mg} / 1$ to $69.71 \mathrm{mg} / 1$ (Figure 10). The highest chloride level in sub-surface water occurred at a residue rate of 20 ton/acre in June 1992. At this fertilizer level, chloride levels decreased over time for all treatments. Throughout most of this monitoring period, the highest chloride levels occurred at a residue rate of 80 ton/acre at this fertilizer rate, except for the month of June 1992.

During this monitoring period, chloride concentrations in sub-surface water did not exceed the drinking water standard of $250 \mathrm{mg} / \mathrm{l}$. Concentrations of chloride were higher in 1992 shortly after plot establishment as compared to chloride levels in 1993, the year after plot establishment. Chloride levels decreased during the period from June 1992 through September 1993. The results suggest that elevated chloride levels in sub-surface water at a depth of 4 feet could be the result of leaching of chlorides from residue applied at a rate of 80 ton/acre, although this relationship has not been statistically tested. De-inking residue had a mean chloride concentration of $287.6 \mathrm{mg} / \mathrm{kg}$. 


\section{NITRITE + NITRATE-NITROGEN}

The water quality analysis for nitrite + nitrate-nitrogen, grouped by fertilizer level during the time April 1993 through September 1993, is presented in Figures 11, 12 and 13. Although the analysis for nitrate-nitrogen began in September 1992, the results for September 1993 are not presented in this section because the levels may not be accurate since an excessive amount of time occurred between sample collection and sample analysis. The results for nitrate-nitrogen are included in Appendix B. The drinking water standard (MCL) for nitrate-nitrogen is $10 \mathrm{mg} / \mathrm{l}$.

Without fertilizer applied to tailings, nitrate-nitrogen ranged from $1.7 \mathrm{mg} / \mathrm{l}$ to $13.8 \mathrm{mg} / 1 \mathrm{during}$ this monitoring period (Figure 11). The highest nitrate-nitrogen levels occurred on the control plot in April 1993 through September 1993. In April 1993 on the control plot, $13.8 \mathrm{mg} / \mathrm{l}$ of nitrate-nitrogen was measured. The lowest nitrate-nitrogen levels occurred on residue amended tailings at 20 ton/acre without fertilizer. Nitrate-nitrogen levels decreased in June and August 1993 but increased slightly in September 1993.

At a fertilizer level of $36 \mathrm{lb} /$ acre $\mathrm{N}$ and $92 \mathrm{lb} /$ acre $\mathrm{P}_{2} \mathrm{O}_{5}(200 \mathrm{lb} /$ acre 18-46-0), nitrate-nitrogen ranged from $1.2 \mathrm{mg} / \mathrm{l}$ to $19.1 \mathrm{mg} / \mathrm{l}$ (Figure 12). The highest nitrate-nitrogen concentration in sub-surface water occurred in April 1993 on tailings amended with residue at 20 ton/acre. The lowest nitrate-nitrogen level occurred on tailings amended with residue at 0 and 80 ton/acre. In June 1993 through September 1993, nitrate levels in sub-surface water were less than $5 \mathrm{mg} / \mathrm{l}$ for the treatments represented by these graphs.

At a fertilizer rate of $72 \mathrm{lb} / \mathrm{acre} \mathrm{N}$ and $184 \mathrm{lb} / \mathrm{acre} \mathrm{P}_{2} \mathrm{O}_{5}(400 \mathrm{lb} /$ acre 18-46-0), nitrate-nitrogen ranged from $1.6 \mathrm{mg} / 1$ to $11.0 \mathrm{mg} / \mathrm{l}$ (Figure 13). The highest nitrate-nitrogen concentration occurred in April 1993 on tailings without residue. The lowest nitrate-nitrogen levels generally occurred on tailings amended with residue at 20 and 80 ton/acre, at this fertilizer level.

The nitrate-nitrogen results suggest that de-inking residue, applied at the highest rate, may immobilize nitrogen supplied as a commercial fertilizer, which would reduce the amount of nitrate-nitrogen in tailings available for plant uptake and losses by leaching. Nitrogen fertilizer applied to tailings amended with residue at 80 ton/acre may be tied-up by microorganisms decomposing the residue. Under these conditions, a limited amount of nitrate-nitrogen would be available in the tailings that could be leached to deeper depths. Although the drinking water standard for nitrate-nitrogen was exceeded, the source of nitrate-nitrogen in sub-surface water is more likely related to the level of nitrogen applied as fertilizer to the plots since de-inking residue contains very low levels of nitrogen.

\section{SULFATE-SULFUR}

The water analysis for sulfate-sulfur, grouped by fertilizer level, for the period June 92 through September 1993 is presented in Figures 14, 15 and 16. The results of this analysis will be compared to the drinking water standard (MCL) of $250 \mathrm{mg} / \mathrm{l}$ for sulfate-sulfur. 
Without fertilizer, sulfate-sulfur ranged from $32.58 \mathrm{mg} / \mathrm{l}$ to $300.80 \mathrm{mg} / 1$ in subsurface water (Figure 14). The highest sulfate-sulfur levels occurred in sub-surface water on tailings amended with residue at 20 ton/acre. The lowest sulfate-sulfur levels occurred at a residue rate of 80 ton/acre at this fertilizer rate, except for the month of June 1992. The drinking water standard for sulfate-sulfur was exceeded in August 1992, September 1992, and September 1993 on tailings amended with 20 ton/acre of residue, without fertilizer.

At a fertilizer rate of $36 \mathrm{lb} /$ acre $\mathrm{N}$ and $92 \mathrm{lb} / \mathrm{acre} \mathrm{P}_{2} \mathrm{O}_{5}(200 \mathrm{lb} / \mathrm{acre} 18-46-0)$, sulfate-sulfur ranged from $29.18 \mathrm{mg} / 1$ to $200.50 \mathrm{mg} / \mathrm{l}$ (Figure 15). Sulfate-sulfur concentrations in sub-surface water were quite variable among the three residue rates 0,20 and 80 ton/acre. In general, sulfate-sulfur levels increased from June 1992 to September 1992 and April 1993 and then decreased to June 1993. A small increase in sulfate-sulfur occurred in August and September 1993, possibly in response to high rainfall during August 1993.

At a fertilizer rate of $72 \mathrm{lb} /$ acre $\mathrm{N}$ and $184 \mathrm{lb} /$ acre $\mathrm{P}_{2} \mathrm{O}_{5}$ (400 lb/acre 18-46-0), sulfate-sulfur levels ranged from $29.44 \mathrm{mg} / \mathrm{l}$ to $157.50 \mathrm{mg} / \mathrm{l}$ (Figure 16). The highest sulfate-sulfur levels in sub-surface water during this monitoring period occurred on tailings without de-inking residue, except for the month of April 1993.

The level of sulfate-sulfur in coarse tailings, prior to plot establishment, was $13 \mathrm{mg} / \mathrm{kg}$ and the level of sulfate-sulfur in de-inking residue was $24.8 \mathrm{mg} / \mathrm{kg}$. Although sulfate-sulfur concentrations exceeded the sulfate-sulfur drinking water standard in sub-surface water on tailings amended with residue at $20 \mathrm{ton} / \mathrm{acre}$, it does not appear that de-inking residue is a significant source of sulfur.

\section{PERCENT VEGETATIVE COVER}

The effects of de-inking residue and fertilizer treatments on plant growth were evaluated by estimating percent vegetative cover. Vegetative cover was estimated four times during the study; in July and September 1992 and in July and September 1993. Two-way analysis of variance using the general linear model procedure in SAS was used to evaluate differences in percent vegetative cover for the main effects of de-inking residue and fertilizer. Contrast statements were used to determine differences among the vegetative cover estimates at the 0.05 significance level. The statistical analysis was done separately for the introduced and native species for each sampling date.

\section{JULY 1992 - INTRODUCED SPECIES}

The vegetative cover estimates in July 1992 represent a growth period of approximately 4-5 weeks between the time of plot establishment and the first measurement of plant cover. This interval is a very short period of time for plant establishment to occur for many species in northern Minnesota. 
In July 1992, there was a response in vegetative cover of introduced species to the main effects of de-inking residue and fertilizer. The mean percent vegetative cover and associated standard deviations for introduced species, measured in July 1992, are presented in Table 8. Means within the same row followed by the same letter are not significantly different at the 0.05 level. The percent vegetative cover for introduced species, grouped by fertilizer treatment, is graphically displayed in Figure 17.

Without fertilizer, vegetative cover ranged from 3.3 percent to 11.1 percent. Mean vegetative cover was significantly higher on tailings without residue and on tailings amended with residue at $40 \mathrm{ton} / \mathrm{acre}$, although the vegetative cover on tailings amended with residue at 40 ton/acre was not significantly different that cover on tailings amended with residue at 10, 20 and 80 ton/acre.

At a fertilizer rate of $200 \mathrm{lb} / \mathrm{acre}$ of $18-46-0\left(\mathrm{~N}=36 \mathrm{lb} / \mathrm{acre} ; \mathrm{P}_{2} \mathrm{O}_{5}=92 \mathrm{lb} / \mathrm{acre}\right)$, mean vegetative covers were slightly higher as compared to treatments without fertilizer. Vegetative cover was significantly higher on tailings without residue and on tailings amended with 40 ton/acre residue, although the cover on residue amended tailings at 40 ton/acre was not significantly different than the cover on residue amended tailings at 10,20 and 80 ton/acre.

At the highest fertilizer rate, $400 \mathrm{lb} / \mathrm{acre}$ of $18-46-0\left(\mathrm{~N}=72 \mathrm{lb} / \mathrm{acre} ; \mathrm{P}_{2} \mathrm{O}_{5}=184 \mathrm{lb} / \mathrm{acre}\right)$, a significantly higher vegetative cover occurred on tailings without residue than on tailings amended with residue. There were no significant differences in vegetative cover among the 10 , 20,40 and 80 ton/acre residue treatments, where plant cover ranged from 3.3 percent to 7.8 percent.

In July 1992, the vegetative cover of introduced species increased slightly as the level of fertilization increased. The effects of fertilization on plant growth were not very pronounced at this time because of the short time interval between plot establishment and the first estimate of plant cover. The July 1992 results indicate that de-inking residue negatively impacted plant growth during the initial establishment of introduced species on coarse tailings.

\section{JULY 1992 - NATIVE SPECIES}

In July 1992, very low vegetative cover estimates occurred on tailings planted to native species (Table 9). The mean plant cover for treatments ranged from 0 percent to a high of only 4.4 percent cover. The vegetative cover estimates for native species measured in July 1992 are graphically displayed in Figure 18.

There were no significant differences in vegetative cover on tailings treated without fertilizer and with fertilizer applied at $200 \mathrm{lb} /$ acre of 18-46-0, across all residue rates, where cover was less than 2.2 percent on these treatments.

At $400 \mathrm{lb} / \mathrm{acre}$ of fertilizer $\left(\mathrm{N}=72 \mathrm{lb} / \mathrm{acre} ; \mathrm{P}_{2} \mathrm{O}_{5}=184 \mathrm{lb} / \mathrm{acre}\right)$, there were significant differences in vegetative cover among the residue rates, but vegetative cover was less that 4.4 percent. 
There was a short period of time between the time plots were seeded and the first measurement of vegetative cover. During this interval, a limited amount of plant growth would be expected as seed germination occurs and plants become established. Furthermore, the cool and wet conditions during this time may account for some initial slow growth rates.

As shown in Figures 17 and 18, the introduced species had a greater amount of vegetative cover as compared to the native species in July 1992 . Much of the initial growth by native plants is reported to be in the development of its root system. The vegetative cover estimates in July 1992 indicate that, during the initial stages of plant establishment, de-inking residue applied without fertilizer, did not benefit the establishment of introduced or native species on coarse tailings.

\section{SEPTEMBER 1992 - INTRODUCED SPECIES}

The vegetative cover measurements in September 1992 represent plant growth levels at the end of one growing season. There was a response in vegetative cover of introduced species to the main effects of fertilizer and de-inking residue in September 1992. The vegetative cover for each treatment is presented in Table 10 and is graphically illustrated in Figure 19.

Without fertilizer, there were no significant differences in vegetative cover among the five residue levels, which ranged from 0 percent to 5.8 percent cover.

At a fertilizer level of $200 \mathrm{lb} / \mathrm{acre}$ of $18-46-0\left(\mathrm{~N}=36 \mathrm{lb} / \mathrm{acre} ; \mathrm{P}_{2} \mathrm{O}_{5}=92 \mathrm{lb} / \mathrm{acre}\right)$, an increase in vegetative cover was associated with the addition of fertilizer. Although the highest cover occurred on tailings amended with residue at 20 ton/acre at this fertilizer level, this plant cover was not significantly different than the mean cover on tailings amended with residue at 0,10 and 40 ton/acre. Cover was significantly higher on the residue amended tailings at 20 ton/acre than at 80 ton/acre.

At a fertilizer rate of $\mathrm{N}=80 \mathrm{lb} /$ acre and $\mathrm{P}_{2} \mathrm{O}_{5}=180 \mathrm{lb} / \mathrm{acre}$, there were significant differences in vegetative cover among the five residue rates. Vegetative cover ranged from a low of 12.2 percent at a residue rate of 80 ton/acre to a high of 42.2 percent at a residue rate of 20 ton/acre, although these cover estimates were not significantly different at the 0.05 level.

At a fertilizer rate of $400 \mathrm{lb} /$ acre $18-46-0\left(\mathrm{~N}=72 \mathrm{lb} / \mathrm{acre}\right.$ and $\mathrm{P}_{2} \mathrm{O}_{5}=184 \mathrm{lb} /$ acre $)$, the highest vegetative cover, 50.0 percent, occurred at a residue rate of $20 \mathrm{ton} /$ acre, although this cover was not significantly different than the cover on residue amended tailings at 0,10 , and 40 ton/acre. The lowest vegetative cover, 10 percent, occurred on tailings with residue applied at 80 ton/acre, although this cover was not significantly different than the cover on residue amended tailings at 40 ton/acre.

At the highest fertilizer level, $160 \mathrm{lb} / \mathrm{acre} \mathrm{N}$ and $359 \mathrm{lb} / \mathrm{acre}$ of $\mathrm{P}_{2} \mathrm{O}_{5}$, a high vegetative cover, 50 percent, occurred on residue amended tailings at 20 ton/acre, although this cover was not significantly different than cover on residue amended tailings at 0,10 and 40 ton/acre. The lowest vegetative cover, 15.6 percent, occurred on residue amended tailings at 80 ton/acre, although this cover was not significantly different that the cover on residue amended tailings at 40 ton/acre. 
The September 1992 vegetative cover results for introduced species indicate that the highest vegetative cover occurred on coarse tailings fertilized at the two highest levels with residue amended at 20 ton/acre.

\section{SEPTEMBER 1992 - NATIVE SPECIES}

In September 1992, there was a response in vegetative cover by native plant species to the main effect of de-inking residue but not to fertilizer. The percent vegetative cover, presented by fertilizer treatment, is shown in Table 11. The vegetative cover for this time period is graphically illustrated in Figure 20.

Without fertilizer, there were no significant differences among the five residue rates. Vegetative cover ranged from a low of 0.6 percent on residue amended tailings at 40 ton/acre to a high of 3.6 percent on tailings without fertilizer or residue.

At a fertilizer level of $200 \mathrm{lb} /$ acre of 18-46-0 $\left(\mathrm{N}=36 \mathrm{lb} /\right.$ acre and $\mathrm{P}_{2} \mathrm{O}_{5}=92 \mathrm{lb} /$ acre $)$, vegetative cover was highest on tailings with only fertilizer, although this cover was not significantly different than vegetative cover on residue amended tailings at 20 ton/acre. Tailings amended with residue at 40 ton/acre and 80 ton/acre had no vegetative cover.

At the fertilizer level of $80 \mathrm{lb} /$ acre $\mathrm{N}$ and $180 \mathrm{lb} / \mathrm{acre} \mathrm{P}_{2} \mathrm{O}_{5} \mathrm{lb} / \mathrm{acre}$, there were no significant differences in vegetative cover for native species in September 1992 among the five residue treatments. Vegetative cover ranged between 1.1 percent and 5.6 percent cover.

At a fertilizer level of $400 \mathrm{lb} /$ acre $18-46-0\left(\mathrm{~N}=72 \mathrm{lb} /\right.$ acre and $\left.\mathrm{P}_{2} \mathrm{O}_{5}=184 \mathrm{lb} / \mathrm{acre}\right)$, a significantly higher vegetative cover, 14.4 percent, occurred on tailings treated with only fertilizer than on residue amended tailings at 10,20,40 and 80 ton/acre. Vegetative cover ranged from no cover to 3.3 percent on residue amended tailings at this fertilizer level.

At the highest fertilizer level, $160 \mathrm{lb} /$ acre $\mathrm{N}$ and $359 \mathrm{lb} /$ acre $\mathrm{P}_{2} \mathrm{O}_{5}$, the highest vegetative cover, 11.7 percent, occurred on tailings with fertilizer only, although this cover was not significantly different than the cover on residue amended tailings at 10 ton/acre. The vegetative cover on residue amended tailings at 10 ton/acre was not significantly different than the vegetative cover on residue amended tailings at 20,40 and 80 ton/acre.

The September 1992 vegetative cover results for native species generally indicate that the highest vegetative cover occurred on tailings without residue at higher fertilizer levels. Low vegetative covers were expected since much of the plant growth by native species during the first few years is in the development of its root system. As shown in Figures 19 and 20, introduced species had a higher vegetative cover as compared to native species in September 1992.

\section{JULY 1993 - INTRODUCED SPECIES}

In July 1993, there was a response in the vegetative cover of introduced species to the main effects of fertilizer and de-inking residue. The vegetative cover, presented by fertilizer treatment, is shown in Table 12 and Figure 21 for this time period. 
Without fertilizer,there were no significant differences in percent vegetative cover among the five residue treatments, which ranged from bare to a high of 3.9 percent cover.

At a fertilizer level of $200 \mathrm{lb} /$ acre of $18-46-0\left(\mathrm{~N}=36 \mathrm{lb} /\right.$ acre and $\mathrm{P}_{2} \mathrm{O}_{5}=92 \mathrm{lb} /$ acre $)$, there were significant differences in vegetative cover among residue treatments. Vegetative cover was significantly higher on tailings amended with residue at 10,20 and 40 ton/acre than on tailings without residue and on tailings amended with residue at 80 ton/acre. Vegetative cover on tailings amended with residue at 10, 20 and 40 ton/acre ranged from 40.0 percent to 60.0 percent cover. Vegetative cover was 8.9 percent on tailings amended with residue at 80 ton/acre and 18.3 percent on tailings with only fertilizer.

At a fertilizer level of $80 \mathrm{lb} /$ acre $\mathrm{N}$ and $180 \mathrm{lb} /$ acre $\mathrm{P}_{2} \mathrm{O}_{5}$, there were significant differences in vegetative cover among the treatments. The highest vegetative covers occurred on tailings amended with residue at 10,20 and 40 ton/acre, although vegetative cover at 40 ton/acre was not significantly different than vegetative cover on tailings at 0 ton/acre and 80 ton/acre. The lowest vegetative cover, 16.7 percent, occurred on residue amended tailings at 80 ton/acre, although this cover was not significantly different than the cover at 0 ton/acre and 40 ton/acre.

At a fertilizer level of $400 \mathrm{lb} /$ acre $18-46-0\left(\mathrm{~N}=72 \mathrm{lb} /\right.$ acre and $\mathrm{P}_{2} \mathrm{O}_{5}=184 \mathrm{lb} /$ acre $)$, there were significant differences in vegetative cover among the residue treatments. Significantly higher vegetative covers occurred on tailings amended with residue at 10,20, and 40 ton/acre, ranging from 55.6 percent to 65.6 percent. Significantly lower vegetative covers, 21.1 percent and 24.4 percent, occurred on tailings with residue applied at 80 ton/acre and on tailings with only fertilizer.

At the highest fertilizer level, $160 \mathrm{lb} /$ acre $\mathrm{N}$ and $359 \mathrm{lb} /$ acre $\mathrm{P}_{2} \mathrm{O}_{5}$, there were significant differences in vegetative cover among the residue treatments, ranging from a low of 26.7 percent on tailings amended with residue at 80 ton/acre to a high of 67.8 percent on tailings amended with residue at 10 ton/acre. Significantly higher vegetative covers occurred on residue amended tailings at 10, 20 and 40 ton/acre, although cover on tailings amended with residue at 40 ton/acre was not significantly different than vegetative cover on tailings at 0 ton/acre and 80 ton/acre. The lowest vegetative cover, 26.7 percent, occurred on tailings amended with residue at 80 ton/acre, which was not significantly different than the cover on tailings with fertilizer only or on tailings amended with residue at 40 ton/acre.

The vegetative cover estimates for introduced species in July 1993 indicate that the highest vegetative cover estimates occurred on tailings fertilized at the higher levels with residue applied at 10 ton/acre and 20 ton/acre.

\section{JULY 1993 - NATIVE SPECIES}

In July 1993, there was a response in the vegetative cover of native species to the main effects of fertilizer and de-inking residue. The percent vegetative cover, presented by fertilizer treatment, is shown in Table 13 . The percent vegetative cover for this time period is graphically illustrated in Figure 22. 
In July 1993, on plots without fertilizer, there were no significant differences in vegetative cover of native species, which ranged from no cover to a high of 3.3 percent.

At a fertilizer level of $200 \mathrm{lb} /$ acre of $18-46-0\left(\mathrm{~N}=36 \mathrm{lb} /\right.$ acre and $\left.\mathrm{P}_{2} \mathrm{O}_{5}=92 \mathrm{lb} / \mathrm{acre}\right)$, the highest cover, 11.7 percent, occurred on tailings amended with only fertilizer. There were no significant differences in vegetative cover on tailings amended with residue at 20,40 , and 80 ton/acre.

At a fertilizer level of $80 \mathrm{lb} /$ acre $\mathrm{N}$ and $359 \mathrm{lb} /$ acre $\mathrm{P}_{2} \mathrm{O}_{5}$, vegetative cover was significantly higher on tailings amended with residue at 10 ton/acre and on tailings only fertilized, where vegetative cover was 14.4 percent and 13.3 percent, respectively. There were no differences in vegetative cover on tailings amended with residue at 20,40 and 80 ton/acre, where vegetative cover ranged from 0.0 percent to 2.2 percent cover.

At a fertilizer level of $400 \mathrm{lb} /$ acre $18-46-0\left(\mathrm{~N}=72 \mathrm{lb} /\right.$ acre and $\mathrm{P}_{2} \mathrm{O}_{5}=184 \mathrm{lb} /$ acre $)$, a significantly higher vegetative cover, 16.1 percent, occurred on tailings without residue than on tailings amended with residue at 10,20, 40 and 80 ton/acre. Vegetative cover on residue amended tailings ranged from 0.0 percent to 4.4 percent cover.

Maximum vegetative cover was achieved for the native species in July 1993 at the highest fertilizer level, $160 \mathrm{lb} /$ acre $\mathrm{N}$ and $359 \mathrm{lb} /$ acre $\mathrm{P}_{2} \mathrm{O}_{5}$. A significantly higher vegetative cover occurred on tailings without residue and on residue amended tailings at 10 ton/acre and 20 ton/acre, ranging between 14.4 percent cover to 27.8 percent cover. A significantly lower vegetative cover, 1.1 percent, occurred on tailings amended with residue at 40 ton/acre and 80 ton/acre than at 0,10 and 20 ton/acre of residue.

The vegetative cover results for native species in July 1993 generally indicate that the highest vegetative cover occurred on tailings fertilized at the highest level without residue, and to a lesser degree, with residue applied at 10 ton/acre. As shown in Figures 21 and 22, introduced species had higher vegetative covers than native species in July 1993.

\section{SEPTEMBER 1993 - INTRODUCED SPECIES}

The vegetative cover measurements in September 1993 represent ground cover conditions after two growing seasons. The DNR mineland rules specify that a 90 percent ground cover shall occur after three growing seasons.

In September 1993, there was a significant response in vegetative cover of introduced species to the main effects of de-inking residue and fertilizer. The percent vegetative cover for each treatment is shown in Table 14 and is graphically displayed in Figure 23. In general, significant increases in vegetative cover of introduced plant species occurred as the level of fertilization increased. Furthermore, the highest vegetative cover occurred on fertilized tailings with deinking residue applied at 10 ton/acre and 20 ton/acre. 
Without fertilizer, vegetative cover on tailings in September 1993 was very low, ranging from 0.6 percent on tailings amended with residue at 10 ton/acre and 80 ton/acre to a high of 11.7 percent on unamended tailings. Vegetative cover was significantly higher on unamended tailings and on tailings amended with residue at 40 ton/acre, although cover on tailings amended with residue at 40 ton/acre was not significantly different from cover on residue amended tailings at 10,20 , and 80 ton/acre. The results clearly indicate that fertilizer is required for the restoration of coarse tailings with vegetation, with or without de-inking residue.

An increase in vegetative cover was associated with the addition of fertilizer to nutrient poor coarse tailings, as expected. At a fertilizer rate of $200 \mathrm{lb} /$ acre $18-46-0(\mathrm{~N}=36 \mathrm{lb} / \mathrm{acre}$ and $\mathrm{P}_{2} \mathrm{O}_{5}=92 \mathrm{lb} / \mathrm{acre}$ ), vegetative cover ranged from a low of 24.4 percent on residue amended tailings at 80 ton/acre to a high of 60.0 percent cover on tailings amended with residue at 10 ton/acre. Significantly higher vegetative cover occurred on tailings amended with residue at 10 , 20 and 40 ton/acre, although cover on tailings amended with residue at 40 ton/acre was not significantly different than cover on tailings amended with residue at 0 ton/acre and 80 ton/acre. The lowest cover occurred on residue amended tailings at 80 ton/acre, although this cover was not significantly different than cover on tailings amended with residue at 0 ton/acre and 40 ton/acre.

At a fertilizer level of $80 \mathrm{lb} /$ acre $\mathrm{N}$ and $180 \mathrm{lb}$ /acre $\mathrm{P}_{2} \mathrm{O}_{5}$, vegetative cover ranged from a low of 22.2 percent on tailings amended with residue at 80 ton/acre to a high of 75.6 percent on tailings amended with residue at 20 ton/acre. The vegetative cover on tailings at $0,10,20$, and 40 ton/acre were not significantly different, although the cover on residue amended tailings at 20 ton/acre was not significantly higher than cover on tailings at 40 ton/acre. The lowest vegetative cover, on residue amended tailings at 80 ton/acre, was significantly less than all other covers at this fertilizer level.

At a fertilizer rate of $400 \mathrm{lb} /$ acre $18-46-0\left(\mathrm{~N}=72 \mathrm{lb} /\right.$ acre and $\mathrm{P}_{2} \mathrm{O}_{5}=184 \mathrm{lb} /$ acre $)$, vegetative cover ranged from a low of 32.2 percent on residue amended tailings at 80 ton/acre to a high of 75.6 percent on tailings amended with residue at 10 ton/acre. A significantly higher vegetative cover occurred on residue amended tailings at 10 ton/acre and 20 ton/acre, although the cover on residue amended tailings at 20 ton/acre was not significantly different than the cover on residue amended tailings at 40 ton/acre. Vegetative cover on tailings amended with residue at 0 ton/acre and 40 ton/acre were not significantly different. The cover on tailings amended with residue at $0,10,20$ and 40 ton/acre was significantly higher than cover on tailings amended residue at 80 ton/acre.

At the highest fertilizer rate, $160 \mathrm{lb} /$ acre $\mathrm{N}$ and $359 \mathrm{lb} /$ acre $\mathrm{P}_{2} \mathrm{O}_{5}$, vegetative cover was highest for all residue treatments at the end of the second growing season in 1993. At this level of fertilization, cover ranged from a low of 44.4 percent on residue amended tailings at 80 ton/acre to a high of 90.0 percent cover on residue amended tailings at 10 ton/acre. Vegetative cover on tailings amended with residue at $0,10,20$ and 40 ton/acre were not significantly different at this fertilizer level. Vegetative cover on tailings amended with residue at $0,10,20$ and 40 ton/acre were significantly higher than the cover on tailings amended with residue at 80 ton/acre. 
The vegetative cover measurements for introduced species indicate that a 90 percent vegetative cover on coarse tailings was achieved at the end of the second growing season at a fertilizer level of $160 \mathrm{lb} /$ acre of nitrogen and $359 \mathrm{lb} /$ acre of phosphorus with residue applied at a rate at 10 ton/acre. On these tailings, alfalfa appeared to be doing particularly well. Statistically, the highest vegetative cover occurred on residue amended tailings at 10 ton/acre and 20 ton/acre with fertilizer applied at the highest level.

\section{SEPTEMBER 1993 - NATIVE SPECIES}

In September 1993, there was a significant response in vegetative cover of native species to the main effects of fertilizer and de-inking residue. The percent vegetative cover, grouped by fertilizer treatment, is shown in Table 15. Vegetative cover is also shown graphically represented in Figure 24.

Without fertilizer, vegetative cover ranged from a low of 2.2 percent on residue amended tailings at 40 ton/acre and 80 ton/acre to a high of 12.2 percent on tailings without fertilizer or residue. Vegetative cover was not significantly different among the treatments 0,10 and 20 ton/acre, although cover on residue amended tailings at 10 ton/acre and 20 ton/acre were not significantly greater than cover estimates on residue amended tailings at 40 ton/acre and 80 ton/acre.

At a fertilizer rate of $200 \mathrm{lb} /$ acre $18-46-0\left(\mathrm{~N}=36 \mathrm{lb} /\right.$ acre and $\mathrm{P}_{2} \mathrm{O}_{5}=92 \mathrm{lb} /$ acre $)$, vegetative cover ranged from bare on tailings amended with residue at 40 ton/acre to 29.4 percent on tailings amended with only fertilizer. Vegetative cover on tailings with only fertilizer had a significantly higher cover than all residue treatments. There were no significant differences in cover among the four residue rates at this fertilizer level.

At a fertilizer rate of $\mathrm{N}=80 \mathrm{lb} /$ acre and $\mathrm{P}_{2} \mathrm{O}_{5}=180 \mathrm{lb} / \mathrm{acre}$, vegetative cover ranged from a low of 2.2 percent on residue amended tailings at 80 ton/acre to a high of 37.2 percent on tailings with only fertilizer. A significantly higher vegetative cover occurred on fertilized tailings, without residue, and on tailings amended with residue at 10 ton/acre. Significantly lower vegetative covers occurred on tailings amended with residue at 20, 40 and 80 ton/acre.

At a fertilizer rate of $400 \mathrm{lb} /$ acre $18-46-0\left(\mathrm{~N}=72 \mathrm{lb} /\right.$ acre and $\mathrm{P}_{2} \mathrm{O}_{5}=184 \mathrm{lb} /$ acre $)$, a significantly higher cover, 36.1 percent, occurred on fertilized tailings, without residue. No significant differences in cover occurred among residue amended tailings at 10, 20, 40 and 80 ton/acre.

At the highest fertilizer level, $160 \mathrm{lb} /$ acre $\mathrm{N}$ and $359 \mathrm{lb} /$ acre $\mathrm{P}_{2} \mathrm{O}_{5}$, vegetative cover ranged from a low of 2.2 percent on residue amended tailings at 80 ton/acre to a high of 68.9 percent on residue amended tailings at 10 ton/acre. The mean vegetative cover on tailings amended with residue at 0,10 and 20 ton/acre were not significantly different, although cover on tailings amended with residue at 20 ton/acre was not significantly different from the cover at a residue rate 40 ton/acre. 
The vegetative cover for native species at the end of the second growing season in 1993 indicate that a high vegetative cover of 68.9 percent occurred on tailings fertilized with $160 \mathrm{lb} /$ acre of nitrogen and $359 \mathrm{lb} /$ acre phosphorus with residue amended at 10 ton/acre. Although neither vegetative cover or biomass of specific plant species were measured on native treatments, Canada wild rye and Kalm's brome appeared to be the most abundant species present while bush clover was rarely observed. Although little bluestem and big bluestem were present on native plots, the above-ground biomass of these native grasses was minimal during the first two growing seasons. Although introduced species continued to have higher vegetative cover estimates than native species in September 1993, the differences between the two groups were less in September 1993 as compared to previous cover estimates. It appears that the native species were beginning to develop above-ground growth at the end of the second growing season.

\section{VEGETATIVE COVER OVER TIME}

Vegetative cover, grouped by plant species and fertilizer treatment, are shown in Figures 25 to 34 for the period July 1992 through September 1993. These graphs illustrate the changes in vegetative cover that occurred over two growing seasons for both groups of plant species. The vertical scale on Figures 25-34 are the same so that visual comparisons can be made among graphs.

Without fertilizer, the mean plant cover for introduced species and native species are shown in Figures 25 and 26, respectively. A minimal amount of vegetative cover was measured on tailings not fertilized. Vegetative cover was less than 8.0 percent on residue amended tailings without fertilizer. The results clearly indicate that de-inking residue, alone, does not supply the necessary amounts of nutrients required for successful plant growth on coarse tailings.

Vegetative cover on residue amended plots, with fertilizer applied at $200 \mathrm{lb} / \mathrm{acre} 18-46-0$ ( $\mathrm{N}=36$ $\mathrm{lb} /$ acre and $\mathrm{P}_{2} \mathrm{O}_{5}=92 \mathrm{lb} /$ acre), are shown in Figure 27 for introduced species and in Figure 28 for native species. Introduced species had a higher vegetative cover on tailings fertilized with $200 \mathrm{lb} /$ acre 18-46-0 in comparison to the level of vegetative cover on control plots (no fertilizer or residue). At this fertilizer rate, the highest vegetative cover for introduced species, 60 percent cover, occurred in 1993 on residue amended tailings at 20 ton/acre. The lowest cover for introduced species occurred on residue amended tailings at 80 ton/acre in 1993, where plant cover ranged from 4.4 percent to 24.4 percent vegetative cover. For native species, the highest plant cover occurred on tailings fertilized with $200 \mathrm{lb} /$ acre 18-46-0. The lowest native plant cover, less than 1.1 percent, occurred on tailings treated with 40 ton/acre and 80 ton/acre residue at this fertilizer rate.

At a fertilizer rate of $80 \mathrm{lb} /$ acre $\mathrm{N}$ and $180 \mathrm{lb} /$ acre $\mathrm{P}_{2} \mathrm{O}_{5}$, the highest plant cover for introduced species in 1993 occurred on residue amended tailings at 10 ton/acre and 20 ton/acre (Figure 31). The lowest vegetative cover for introduced species, at this fertilizer rate, occurred on tailings amended with residue at 80 ton/acre. For native species in 1993, highest vegetative cover was measured on tailings treated with fertilizer and on tailings amended with residue at 10 ton/acre (Figure 32). Lowest vegetative cover for native species, at this fertilizer rate, occurred on tailings amended with residue at the highest rates, 40 ton/acre and 80 ton/acre. 
At a fertilizer level of $400 \mathrm{lb} / \mathrm{acre} 18-46-0\left(72 \mathrm{lb} / \mathrm{ac} \mathrm{N}\right.$ and $\left.184 \mathrm{lb} / \mathrm{ac} \mathrm{P}_{2} \mathrm{O}_{5}\right)$, vegetative cover for introduced species was highest in 1993 on tailings amended with 10 ton/acre and 20 ton/acre residue (Figure 29). The lowest vegetative cover for introduced species occurred on tailings amended residue at 80 ton/acre at this fertilizer rate, with the exception of July 1992. For native species, the highest plant cover occurred on tailings treated with fertilizer only, with the exception of July 1992 (Figure 30). The lowest vegetative cover for native species, at this fertilizer rate, occurred on tailings amended with residue at 80 ton/acre, with the exception of July 1992.

At the highest fertilizer level, $160 \mathrm{lb} / \mathrm{acre} \mathrm{N}$ and $359 \mathrm{lb} / \mathrm{acre} \mathrm{P}_{2} \mathrm{O}_{5}$, the highest vegetative cover for introduced species occurred in 1993 on residue amended tailings at 10 ton/acre and 20 ton/acre (Figure 33). The lowest vegetative cover for introduced species, at this fertilizer rate, occurred on the residue amended tailings at 80 ton/acre. For native species at this fertilizer rate, the highest plant cover in 1993 occurred on the residue amended tailings at 10 ton/acre residue (Figure 34). The lowest plant cover for native species at this fertilizer rate occurred on the residue amended tailings at 80 ton/acre.

\section{CHEMICAL ANALYSIS OF VEGETATION}

Plant analysis is often used to determine the nutrient composition of plants and the effects of treatments in field experiments. The concentration of elements in plants is determined from vegetation samples collected at a specific stage of plant development. Plant analysis can include either total or soluble (extractable) levels of elements and essential nutrients in specific plant parts. The concentration of plant nutrients and other elements can change substantially over time, depending upon plant species and variety, plant part sampled, stage of growth, and geographic location.

The objectives of plant analysis in this study were to determine 1) the level of nutrients in plants and if these levels were above or below the critical or optimum concentration, and 2) the effects of fertilizer and de-inking residue on nutrient levels in plants.

The critical level of nutrients and other elements in plants has been established for many agricultural, horticultural, and wood fiber crops. The critical level is generally referred to as the concentration below which either plant yields decrease or visible nutrient deficiency symptoms appear. The critical level can be further defined as the level of a plant nutrient that produces a 10 percent reduction in plant growth due to a low supply of plant nutrients (Ulrich, 1976). Because the exact level of nutrients below which yields decrease is difficult to determine, the critical level is typically reported for individual plants, for specific parts of plants sampled at a particular stage of growth.

Published critical levels for alfalfa grown in pure stands, with associated references, are shown in Table 16 for the elements nitrogen, phosphorus, potassium, calcium, magnesium, boron, manganese, iron, zinc, and copper. Although alfalfa was not grown in pure stands at Eveleth Mines, these critical values may provide some relevant information as to the nutritional status of alfalfa. 
The metals cadmium, chromium, nickel, and lead are important because of their potential impacts on plant growth and human health. Cadmium and lead can be toxic to humans and animals while chromium and nickel can be phytotoxic to plants at high concentrations. Suggested toxic or tolerance levels for cadmium, chromium, nickel, and lead levels in plants are presented in Table 16.

\section{OCTOBER 1992}

The chemical analyses for alfalfa and grass samples collected in October 1992, from plots seeded to introduced species, are presented in Table 17. A small number of plant samples were collected and analyzed in 1992 because of the minimal amount of above-ground plant growth that was established at the end of the first growing season.

\section{Alfalfa}

The total nitrogen content of alfalfa indicates that nitrogen was above the critical level of 2.0 $\mathrm{mg} / \mathrm{kg}$ for alfalfa grown in pure stands in October 1992. Total kjeldahl nitrogen (TKN) ranged from 2.9 percent to 3.5 percent. Alfalfa is a legume which typically has the bacteria Rhizobia growing in nodules on roots that fix atmospheric nitrogen. In this study, alfalfa was collected from plots fertilized with nitrogen at $72 \mathrm{lb} /$ acre to $160 \mathrm{lb} /$ acre. These results suggest that in October 1992, nitrogen was probably not limiting the growth of alfalfa, and the amount of nitrogen supplied to alfalfa by nitrogen fixation is not known.

Total phosphorus ranged between $1,359 \mathrm{mg} / \mathrm{kg}$ and $3,061 \mathrm{mg} / \mathrm{kg}$. The deficient level for phosphorus is $1,800 \mathrm{mg} / \mathrm{kg}$ and adequate levels of phosphorus in alfalfa is reported to range between $2,000 \mathrm{mg} / \mathrm{kg}$ and $5,000 \mathrm{mg} / \mathrm{kg}$. Phosphorus in alfalfa was highest on the plot fertilized at a high level without de-inking residue. On the remaining plots tested, the phosphorus content in alfalfa was below the adequate level of $2,000 \mathrm{mg} / \mathrm{kg}$. The results indicate that phosphorus could be limiting the growth of alfalfa on coarse tailings in 1992 .

Total potassium in alfalfa ranged from a low of $14,123 \mathrm{mg} / \mathrm{kg}$ to a high of $30,636 \mathrm{mg} / \mathrm{kg}$. The critical value for potassium is $22,000 \mathrm{mg} / \mathrm{kg}$ and the deficiency level is less than $10,000 \mathrm{mg} / \mathrm{kg}$. The highest potassium levels, $25,505 \mathrm{mg} / \mathrm{kg}$ and $30,636 \mathrm{mg} / \mathrm{kg}$, occurred on fertilized plots without de-inking residue. All plots amended with residue had potassium levels less than the critical level, and as the application rate of residue increased from 10 ton/acre to 80 ton/acre, the level of potassium in alfalfa decreased from approximately $20,000 \mathrm{mg} / \mathrm{kg}$ to $14,000 \mathrm{mg} / \mathrm{kg}$. The results suggest that, in 1992, de-inking residue may have impacted the uptake of potassium by alfalfa.

The levels of calcium and magnesium in alfalfa in 1992 exceeded published critical levels. The critical level for calcium in alfalfa is $18,000 \mathrm{mg} / \mathrm{kg}$. Calcium ranged between 21,180 and $39,289 \mathrm{mg} / \mathrm{kg}$ on the plots sampled in 1992 . The critical level for magnesium in alfalfa is 2,500 $\mathrm{mg} / \mathrm{kg}$ and, on the plots sampled, magnesium ranged between 4,792 and $13,927 \mathrm{mg} / \mathrm{kg}$. Higher levels of calcium in alfalfa typically occurred on residue amended plots at 20, 40 , and 80 ton/acre while higher magnesium levels occurred in alfalfa on plots without de-inking residue. Higher calcium levels in alfalfa on residue amended plots could be attributed to the fairly high 
levels of extractable calcium in residue, a mean extractable calcium content of $69,214.60 \mathrm{mg} / \mathrm{kg}$ (Table 3). In contrast, de-inking residue had a mean concentration of $659.13 \mathrm{mg} / \mathrm{kg}$ of extractable magnesium. The coarse tailings at Eveleth Mines had comparable levels of extractable calcium and magnesium, $8,364.83 \mathrm{mg} / \mathrm{kg}$ and $8,487.05 \mathrm{mg} / \mathrm{kg}$, respectively (Table 2).

Boron in alfalfa ranged from a low of $20.7 \mathrm{mg} / \mathrm{kg}$ on a plot amended with residue at 40 ton/acre to a high of $84.1 \mathrm{mg} / \mathrm{kg}$ on a plot without residue. In alfalfa, all boron levels were above the published critical level for boron, $20 \mathrm{mg} / \mathrm{kg}$. Lower boron levels typically occurred in alfalfa on residue amended plots.

Manganese in alfalfa ranged from a low of $119 \mathrm{mg} / \mathrm{kg}$ on a plot amended with residue at 80 ton/acre to a high of $488 \mathrm{mg} / \mathrm{kg}$ on a plot without residue. All plots had manganese levels in excess of the critical level for alfalfa, $10 \mathrm{mg} / \mathrm{kg}$ to $15 \mathrm{mg} / \mathrm{kg}$. Coarse tailings at Eveleth Mines had relatively high levels of manganese, with a mean manganese level of $3,489 \mathrm{mg} / \mathrm{kg}$ (Table 2). Lower levels of manganese in alfalfa occurred on residue amended plots.

Iron in alfalfa was very high and exceeded the critical level for alfalfa, $40 \mathrm{mg} / \mathrm{kg}$ to $44 \mathrm{mg} / \mathrm{kg}$, for all plots sampled. Iron in alfalfa is high because of dust contamination from nearby unstabilized tailings high in iron. Washing of plant materials is necessary to remove dust particles which contain elevated levels of iron and aluminum that accumulate on plant surfaces (Jones and Case, 1990).

In alfalfa, zinc was below the critical level $(15 \mathrm{mg} / \mathrm{kg}$ to $20 \mathrm{mg} / \mathrm{kg})$ for all plots sampled. Zinc ranged from a low of $6.1 \mathrm{mg} / \mathrm{kg}$ on a plot without residue to a high of $12.1 \mathrm{mg} / \mathrm{kg}$ of a plot with residue applied at 40 ton/acre. Higher zinc levels in alfalfa occurred on residue amended plots. Coarse tailings at Eveleth Mines contained $0.13 \mathrm{mg} / \mathrm{kg}$ of extractable zinc and $12.42 \mathrm{mg} / \mathrm{kg}$ of total zinc while de-inking residue contained $12.07 \mathrm{mg} / \mathrm{kg}$ of extractable zinc and $38.67 \mathrm{mg} / \mathrm{kg}$ of total zinc. The source of zinc in de-inking residue is likely due to inks present in recycled paper.

The level of copper in alfalfa ranged from a low of $3.9 \mathrm{mg} / \mathrm{kg}$ on a residue amended plot at 20 ton/acre to a high of $7.1 \mathrm{mg} / \mathrm{kg}$ on a plot without residue. The critical level for copper, 5 $\mathrm{mg} / \mathrm{kg}$, was exceeded on all but two plots. These two plots were amended with residue at 20 ton/acre.

In alfalfa, the tolerance levels for cadmium, $1 \mathrm{mg} / \mathrm{kg}$, and chromium, $2 \mathrm{mg} / \mathrm{kg}$, were not exceeded. The tolerance level for nickel, $3 \mathrm{mg} / \mathrm{kg}$, was exceeded on a plot without residue. The tolerance level for lead, $10 \mathrm{mg} / \mathrm{kg}$, was also exceeded on a fertilized plot with residue at 40 ton/acre. The results generally indicate that these metals did not accumulate to toxic levels in alfalfa in October 1992.

Chloride is an essential micronutrient required for plant growth. Chloride levels in alfalfa were highest on residue amended plots. Chloride in alfalfa on plots without residue were 1,262 $\mathrm{mg} / \mathrm{kg}$ and $1,314 \mathrm{mg} / \mathrm{kg}$. On residue amended plots, chloride ranged from $3,215 \mathrm{mg} / \mathrm{kg}$ to $4,696 \mathrm{mg} / \mathrm{kg}$. It appears from this limited data set that de-inking residue, which had a mean concentration of $286.7 \mathrm{mg} / \mathrm{kg}$ of chloride, may be providing alfalfa with chloride. 


\section{Grasses}

The results of the chemical analysis for grasses are shown in Table 16. No attempt was made to sample the grasses by species in 1992, although there are differences in nutrient levels for different grasses. The data set for grasses in 1992 is too small to make comparisons in nutrient levels by treatment.

\section{SEPTEMBER 1993}

The chemical analyses for plant samples, collected September 15-20, 1993, from two sub-plots per plot, are presented in this section of the report. The native species encountered within subplots included little and big bluestem, kalm's brome, and Canada wild rye. No attempt was made to distinguish between big and little bluestem because the plants were very small, generally less than 1-2 inches in height, making it difficult to differentiate between the bluestem species at this stage of growth. The introduced plant species sampled from sub-plots included smooth bromegrass, red fescue, perennial rye grass, alfalfa, and buckwheat. Although no attempt was made to determine the diversity of volunteer plant species on plots, the species within sub-plots included Agropyron repens (quackgrass), Artemisia spp (wormwood), Chrysanthemum leucanthemum (ox-eye daisy), Crepis tectorum (smooth hawk's beard), Kochia scoparia (kochia), Polygorum pennsylvanicum (Pennsylvania smartweed), Salix spp (willow), Salsola kali (Russian thistle), and Sonchus spp (sow thistle). Numerous other volunteer plant species were sampled from sub-plots but were not identified because of the small size of plants.

Approximately 600 plant samples were collected, processed, and analyzed in 1993. Although this is a relatively large number of plant samples, treatments by plant type (introduced and native) did not have the same species within sub-plots. Consequently, individual plant species were not consistently encountered within sub-plots by treatment, with the exception of alfalfa and bluestem, which occurred on most plots planted with these two species. Therefore, the statistical analysis of the plant analytical results was limited to alfalfa and bluestem. Two-way analysis of variance using the general linear model in SYSTAT was used to evaluate differences in elemental concentrations in alfalfa and bluestem for the main effects de-inking residue and fertilizer. Differences between means were determined using the Tukey-Kramer HSD multiple comparison test at the 0.05 level of significance. Basic summary statistics for the plant analysis data for buckwheat, fescue, smooth bromegrass, Canada wild rye, kalm's brome, and the volunteer species kochia, Russian thistle, and smooth hawk's beard are presented in the report.

Alfalfa

The plant analysis results for alfalfa are presented in Table 18. The statistical analysis for alfalfa includes only four fertilizer rates because no alfalfa samples were collected from plots not fertilized. There were no significant differences in elemental concentrations in alfalfa due to the main effects of fertilizer rate or to the interaction between fertilizer and de-inking residue rate. There were significant differences, however, in elemental levels in alfalfa due to the main effect of de-inking residue rate for boron, magnesium, and manganese. There were no significant differences in the concentrations of aluminum, calcium, cadmium, chromium, copper, potassium, sodium, nickel, phosphorus, lead, and zinc due to treatment effects. The mean elemental 
concentrations in alfalfa reported in Table 18 were averaged across fertilizer rates for each residue rate, since fertilizer did not significantly effect elemental concentrations in alfalfa.

In alfalfa, mean boron concentrations were significantly different due to the main effect of deinking residue, as shown in Table 18 and Figure 35. The highest mean boron level in alfalfa, $55.8 \mathrm{mg} / \mathrm{kg}$, occurred on plots not amended with de-inking residue, although this boron level was not significantly different than boron levels in alfalfa amended with 10 ton/acre and 80 ton/acre of de-inking residue. The lowest mean boron concentration, $15.8 \mathrm{mg} / \mathrm{kg}$, occurred on plots amended with residue at 40 ton/acre, although this boron level was not significantly different than boron measured in alfalfa grown at other residue rates, which ranged between 17.2 $\mathrm{mg} / \mathrm{kg}$ and $22.4 \mathrm{mg} / \mathrm{kg}$. The critical value for boron in alfalfa grown in pure stands is $20 \mathrm{mg} / \mathrm{kg}$ (Chapman, 1987). Boron levels in alfalfa on residue amended plots ranged between $15.8 \mathrm{mg} / \mathrm{kg}$ and $22.4 \mathrm{mg} / \mathrm{kg}$, slightly below and above the critical level, while the mean boron level on plots without residue, $55.8 \mathrm{mg} / \mathrm{kg}$, was above the critical level. The data suggests that de-inking residue is affecting the level of boron uptake by alfalfa grown on coarse tailings.

The magnesium level in alfalfa was significantly different due to the main effect of de-inking residue, as shown in Table 18 and Figure 36. The highest mean magnesium level in alfalfa, $7,282 \mathrm{mg} / \mathrm{kg}$, occurred on plots not amended with de-inking residue, although this magnesium level was not significantly different than magnesium in alfalfa at 10 ton/acre $(3,513 \mathrm{mg} / \mathrm{kg})$. Significantly lower concentrations of magnesium in alfalfa occurred on residue amended plots at 20,40 , and 80 ton/acre as compared to plots not amended with residue, which ranged between $2,663 \mathrm{mg} / \mathrm{kg}$ and $2,926 \mathrm{mg} / \mathrm{kg}$ of magnesium. There were no significant differences in the level of magnesium in alfalfa among residue amended plots. The mean magnesium concentrations for all residue treatments exceeded the critical value for magnesium in alfalfa grown in pure stands, $2,500 \mathrm{mg} / \mathrm{kg}$ (Chapman, 1987).

In alfalfa, significant differences in manganese occurred due to the main effect of de-inking residue, as shown in Table 18 and Figure 37. The highest mean manganese level in alfalfa, $306.0 \mathrm{mg} / \mathrm{kg}$, occurred on plots not amended with residue, although this manganese level was not significantly different than manganese in alfalfa on plots amended with residue at 10,20 , and 40 ton/acre. The lowest mean manganese concentration, $110.0 \mathrm{mg} / \mathrm{kg}$, occurred on plots amended with residue at 80 ton/acre, although this level was not significantly different than manganese in alfalfa grown on plots amended with residue at 10,20 , and 40 ton/acre. The mean manganese concentrations in alfalfa were all substantially greater than the critical level for manganese, $10 \mathrm{mg} / \mathrm{kg}$ to $15 \mathrm{mg} / \mathrm{kg}$, for alfalfa grown in pure stands (Chapman, 1967). An excessive level of manganese in mature leaf tissue, not specific to alfalfa, is approximately 500 $\mathrm{mg} / \mathrm{kg}$ (Jones, 1972).

Although there were no significant differences in phosphorus in alfalfa due to fertilizer or deinking residue rate, relatively low mean phosphorus levels occurred in alfalfa on coarse tailings. The critical value for phosphorus in alfalfa grown in pure stands is between $1,800 \mathrm{mg} / \mathrm{kg}$ and $2,000 \mathrm{mg} / \mathrm{kg}$ (Chapman, 1967). The highest mean phosphorus content in alfalfa, $2,335 \mathrm{mg} / \mathrm{kg}$, occurred on plots not amended with de-inking residue. On residue amended plots, the mean phosphorus content in alfalfa ranged from $1,222 \mathrm{mg} / \mathrm{kg}$ to $1,591 \mathrm{mg} / \mathrm{kg}$, all below the critical level for alfalfa grown in pure stands, which suggests that de-inking residue may have an effect on phosphorus uptake by alfalfa grown on coarse tailings. 
The mean potassium content in alfalfa ranged from a low of $13,047 \mathrm{mg} / \mathrm{kg}$ on residue amended plots at 20 ton/acre to a high of $25,501 \mathrm{mg} / \mathrm{kg}$ on plots not amended with residue, although these levels were not significantly different at the 0.05 level. The critical value for potassium in alfalfa grown in pure stands is between $10,000 \mathrm{mg} / \mathrm{kg}$ (Bailey, 1983) to 22,000 $\mathrm{mg} / \mathrm{kg}$ (Walker et. al., 1987). Lower mean potassium levels in alfalfa tended to occur on residue amended plots. Although these potassium levels were not significantly different, the data suggests that de-inking residue may impact potassium levels in alfalfa grown on coarse tailings.

Although there were no statistical differences at the 0.05 level in the calcium content in alfalfa, the calcium level is relatively low. The critical value for calcium in alfalfa grown in pure stands is between $18,000 \mathrm{mg} / \mathrm{kg}$ and $22,000 \mathrm{mg} / \mathrm{kg}$ (Nelson \& Berber, 1964). In this study, the mean calcium content in alfalfa ranged from a low of $16,702 \mathrm{mg} / \mathrm{kg}$ on plots amended with residue at 10 ton/acre to a high of $24,633 \mathrm{mg} / \mathrm{kg}$ on plots amended with residue at $80 \mathrm{ton} / \mathrm{acre}$.

Cadmium, chromium, copper, nickel, lead, and zinc in alfalfa were not significantly different at the 0.05 level. Mean cadmium concentrations in alfalfa ranged from a low of $0.18 \mathrm{mg} / \mathrm{kg}$ on plots amended with residue at $10 \mathrm{ton} /$ acre to a high of $0.98 \mathrm{mg} / \mathrm{kg}$ on plots without residue. Mean cadmium levels in alfalfa were all below a concentration of $1 \mathrm{mg} / \mathrm{kg}$ reported to be phytotoxic to plants (Northeast Regional Research Publ., 1985).

The mean concentrations of chromium in alfalfa ranged from a low of $0.82 \mathrm{mg} / \mathrm{kg}$ on residue amended plots at 10 ton/acre and 20 ton/acre to a high of $2.12 \mathrm{mg} / \mathrm{kg}$ on plots without de-inking residue, although these chromium levels were not significantly different at the 0.05 level. A chromium concentration of $2 \mathrm{mg} / \mathrm{kg}$ could be phytotoxic to plants (Northeast Regional Research Publ., 1985).

The mean concentrations of copper in alfalfa ranged from a low of $4.9 \mathrm{mg} / \mathrm{kg}$ on plots amended with de-inking residue at $10 \mathrm{ton} /$ acre to a high of $9.8 \mathrm{mg} / \mathrm{kg}$ on plots without de-inking residue, although copper concentrations were not significantly different at the 0.05 level. The critical value for copper in alfalfa in pure stands is $5 \mathrm{mg} / \mathrm{kg}$ (Chapman, 1967).

In alfalfa, mean nickel concentrations ranged from a low of $2.0 \mathrm{mg} / \mathrm{kg}$ on residue amended plots at $10 \mathrm{ton} /$ acre and $40 \mathrm{ton} /$ acre to a high of $10.1 \mathrm{mg} / \mathrm{kg}$ on plots without de-inking residue, although nickel concentrations in alfalfa were not significantly different at the 0.05 level. Phytotoxic levels of nickel in plants can occur at $3 \mathrm{mg} / \mathrm{kg}$ (Northeast Regional Research Publ., 1985).

The mean lead concentrations in alfalfa ranged from a low of $3.0 \mathrm{mg} / \mathrm{kg}$ on residue amended plots at $20 \mathrm{ton} /$ acre to a high of $13.4 \mathrm{mg} / \mathrm{kg}$ on plots without residue, although lead levels were not significantly different at the 0.05 level. A lead content of $10 \mathrm{mg} / \mathrm{kg}$ could be considered phytotoxic to plants (Northeast Regional Research Publ., 1985).

The mean zinc content in alfalfa ranged from a low of $10.7 \mathrm{mg} / \mathrm{kg}$ on residue amended plots at $10 \mathrm{ton} /$ acre to a high of $16.6 \mathrm{mg} / \mathrm{kg}$ on plots amended with residue at $80 \mathrm{ton} / \mathrm{acre}$, although these zinc levels were not significantly different at the 0.05 level. The critical level for zinc in alfalfa grown in pure stands is between $15 \mathrm{mg} / \mathrm{kg}$ and $20 \mathrm{mg} / \mathrm{kg}$ (Chapman, 1967). The data suggest that zinc could be limiting the growth of alfalfa on coarse tailings. 


\section{Buckwheat}

The analytical results for buckwheat are presented in Table 19. Statistical analysis of the data was not completed because of the small number of buckwheat plant samples collected $(n=52)$ from residue amended plots. Approximately 83 percent of the buckwheat samples were collected from plots not amended with de-inking residue.

\section{Red Fescue}

The plant analysis results for red fescue are presented in Table 20. Statistical analysis of the data was not possible because of the small number of plant samples $(n=81)$ collected from plots. Approximately 81 percent of the red fescue samples were collected from plots not amended with de-inking residue.

\section{Smooth Bromegrass}

The plant analysis results for smooth bromegrass are presented in Table 21 . Statistical analysis of the data was not completed because of the small number of plant samples $(n=62)$ collected from plots. Approximately 87 percent of the smooth bromegrass samples were collected from plots not amended with de-inking residue.

\section{Bluestem Grass}

The statistical analyses for bluestem included the residue rates $0,10,20$, and 40 ton/acre and all fertilizer rates. On plots amended with de-inking residue at 80 ton/acre, a small number $(n=6)$ of bluestem samples were collected for chemical characterization.

There were significant differences at the 0.05 level in the elemental concentrations in bluestem due to the main effects of de-inking residue rate, fertilizer rate, and the interaction between fertilizer and de-inking residue. Significant differences occurred in the concentrations of calcium, magnesium, manganese, and zinc in bluestem due to the effects of de-inking residue. There were significant differences in the levels of potassium, magnesium, and phosphorus in bluestem due to the main effect of fertilizer. The interaction effect between residue and fertilizer was significant for only aluminum and manganese in bluestem. The bluestem analytical results, grouped by de-inking residue rate and averaged across fertilizer levels, are shown in Table 22.

Calcium content was significantly different in bluestem due to the main effect of de-inking residue, as shown in Table 22 and Figure 38. The calcium content in bluestem increased as the amount of de-inking residue increased to 40 ton/acre. The highest mean calcium concentration, $8,012 \mathrm{mg} / \mathrm{kg}$, occurred on residue amended plots at 40 ton/acre, although the calcium level was not significantly higher than calcium in bluestem on plots amended with 20 ton/acre residue, $6,367 \mathrm{mg} / \mathrm{kg}$. The lowest mean calcium level, $4,215 \mathrm{mg} / \mathrm{kg}$, occurred in bluestem on plots without de-inking residue, although this calcium level was not significantly different than bluestem on plots amended with 10 ton/acre of residue, $5,087 \mathrm{mg} / \mathrm{kg}$. Mean calcium contents in bluestem were not significantly different on plots amended with residue at 10 ton/acre and 20 ton/acre. 
The magnesium content in bluestem was significantly different due to the effect of de-inking residue, as shown in Table 22 and Figure 39. The statistics show that the magnesium level in bluestem tended to decrease as the amount of de-inking residue increased. The highest mean magnesium content in bluestem, $3,050 \mathrm{mg} / \mathrm{kg}$, occurred on plots amended with residue at 10 ton/acre, although this magnesium content was not significantly different than plots without residue and with residue applied at 20 ton/acre. The lowest mean magnesium concentration in bluestem, $2,251 \mathrm{mg} / \mathrm{kg}$, occurred on plots amended with residue at 40 ton/acre, although this magnesium level was not significantly different than magnesium in bluestem on plots amended with residue at 20 ton/acre, $2,788 \mathrm{mg} / \mathrm{kg}$.

Manganese level in bluestem was significantly different due to the main effect of de-inking residue, as shown in Table 22 and Figure 40. The interaction effect of de-inking residue and fertilizer rate on manganese levels in bluestem was also significant. The manganese content in bluestem decreased as the level of de-inking residue increased. The highest mean manganese level, $329.7 \mathrm{mg} / \mathrm{kg}$, occurred on plots without residue, although this level was not significantly different that the mean content in bluestem on plots amended with 10 ton/acre residue. The lowest mean manganese level, $173.3 \mathrm{mg} / \mathrm{kg}$, occurred on plots amended with residue at 40 ton/acre, although this was not significantly different than the manganese level on plots amended with residue at 10 ton/acre and 20 ton/acre.

Zinc was significantly different in bluestem due to the effect of de-inking residue, as shown in Table 22 and Figure 41. A high mean zinc content in bluestem, $20.7 \mathrm{mg} / \mathrm{kg}$, occurred on residue amended plots at 20 ton/acre, although this zinc level was not significantly different than other residue amended plots. The lowest mean zinc content in bluestem was $13.9 \mathrm{mg} / \mathrm{kg}$, although this level was not significantly different than zinc in bluestem on plots amended with 40 ton/acre residue. The results generally indicate that zinc in bluestem tended to increase with the application of de-inking residue.

The bluestem plant analysis, grouped by fertilizer rate across de-inking residue treatments, are presented in Table 23 for the elements potassium, magnesium, and phosphorus. The level of potassium in bluestem increased as the level of fertilization increased, even though no potassium fertilizer was applied. The highest mean potassium content in bluestem occurred when 160 lb/acre of nitrogen and $359 \mathrm{lb} /$ acre phosphorus $\left(\mathrm{P}_{2} \mathrm{O}_{5}\right)$ were applied, although this potassium level was not significantly different from other fertilized plots. The lowest potassium level in bluestem, 3,997 mg/kg, occurred on plots without fertilizer and this was significantly lower than all other fertilizer rates. The increase in potassium content in bluestem with fertilization is likely attributed to the synergistic effect with other plant nutrients applied using commercial fertilizer.

The level of magnesium in bluestem increased as the level of fertilization increased (Table 23). As previously discussed, the level of magnesium in bluestem decreased as the level of de-inking residue increased. The highest mean magnesium level in bluestem, 3,419 $\mathrm{mg} / \mathrm{kg}$, occurred at the highest fertilizer rate, although this magnesium level was not significantly higher on plots fertilized with $72 \mathrm{lb} /$ acre and $80 \mathrm{lb} /$ acre of nitrogen. The lowest magnesium level in bluestem, $2,371 \mathrm{mg} / \mathrm{kg}$, occurred on plots fertilized with $36 \mathrm{lb} /$ acre of nitrogen, although this magnesium level was not significantly different from magnesium levels in bluestem on plots without fertilizer and on plots with nitrogen applied at $72 \mathrm{lb} /$ acre and $80 \mathrm{lb} / \mathrm{acre}$. 
Phosphorus levels in bluestem increased as the level of fertilization increased (Table 23). The highest phosphorus level in bluestem, $1,598.8 \mathrm{mg} / \mathrm{kg}$, occurred on plots fertilized with phosphorus at $359 \mathrm{lb} /$ acre of $\mathrm{P}_{2} \mathrm{O}_{5}$, although this phosphorus level was not significantly different from plots fertilized with $180 \mathrm{lb} /$ acre and $184 \mathrm{lb} /$ acre of $\mathrm{P}_{2} \mathrm{O}_{5}$. The lowest phosphorus level, $470.1 \mathrm{mg} / \mathrm{kg}$, occurred on plots without any fertilizer, although this phosphorus level was not significantly different from plots fertilized with $92 \mathrm{lb}$ /acre of $\mathrm{P}_{2} \mathrm{O}_{5}$. There were no significant differences in the phosphorus content in bluestem on plots fertilized with phosphorus at 92 $\mathrm{lb} / \mathrm{acre}, 180 \mathrm{lb} / \mathrm{acre}$, and $184 \mathrm{lb} / \mathrm{acre}$ of $\mathrm{P}_{2} \mathrm{O}_{5}$.

\section{Canada Wild Rye}

The plant analysis results for Canada wild rye are presented in Table 24. Statistical analysis of the data was not possible because of the small number of plant samples $(n=77)$ collected from plots. Approximately 62 percent of the Canada wild rye samples were collected from plots not amended with de-inking residue and 19 percent of the samples were collected from plots amended with residue at 10 ton/acre.

Kalm's Brome

The plant analysis results for kalm's brome are presented in Table 25. Statistical analysis of the data was not possible because of the small number of plant samples $(n=60)$ collected from plots. Approximately 35 percent of the kalm's brome samples were collected from plots not amended with de-inking residue and 48 percent of the samples were collected from plots amended with residue at 10 ton/acre and 20 ton/acre.

\section{Volunteer Species}

The chemical analysis for the volunteer species kochia, Russian thistle, and smooth hawk's beard are presented in Table 26. A statistical analysis of the data was not possible due to the limited number of samples for different treatments and the lack of published literature regarding nutrients in these species.

\section{SUMMARY AND CONCLUSIONS}

De-inking residue amended to coarse taconite tailings appears to have benefited the growth of vegetation after two years at Eveleth Mines, when fertilizer is applied. This two-year study indicates that de-inking residue, amended at 10 ton/acre and 20 ton/acre with fertilizer at a high rate, had a higher vegetative cover than tailings amended with only fertilizer at the end of the second growing season.

The coarse tailings at Eveleth Mines are nutrient deficient and have an alkaline $\mathrm{pH}$, low organic matter content, low carbon content, low cation exchange capacity and a low capacity to supply plants with water during the short growing season in northeast Minnesota. De-inking residue had a high $\mathrm{C}: \mathrm{N}$ ratio, 123:1, indicating that immobilization of nitrogen would be a problem when de-inking reside is applied with inadequate amounts of nitrogen fertilizer. De-inking residue does not provide a significant amount of nitrogen, phosphorus, or sulfur to plants since the levels of 
these nutrients in residue are very low. Metal concentrations in de-inking residue were low and less than 1.0 percent of the ceiling concentrations allowed in municipal sewage sludge to be land applied.

De-inking residue had a minimal effect on the chemical characteristics of tailings, although the highest chloride levels were measured on residue amended plots at high residue rates. The effects of de-inking residue on coarse tailings, fertilized at the high rate, may be influenced more by the effects of commercial fertilizer than by de-inking residue. Chloride levels were higher on residue amended plots, especially at 80 ton/acre. The levels of metals in tailings amended with residue were less than the levels found in typical Minnesota soils.

De-inking residue did not appear to have an effect on the level of boron in sub-surface water at a depth of 4 feet. Boron in sub-surface water did not exceed the drinking water standard. Chloride concentrations in sub-surface water did not exceed the drinking water standard, although chlorides were higher in 1992 shortly after plot establishment as compared to levels in 1993. The results suggest that elevated chloride levels in sub-surface water at a depth of 4 feet could be the result of leaching of chlorides from residue applied at a rate of 80 ton/acre. The nitrate-nitrogen results suggest that de-inking residue, applied at the highest rate, may immobilize nitrogen supplied as fertilizer, which would reduce the amount of nitrate-nitrogen in tailings available for plant uptake and losses by leaching. Although sulfate-sulfur concentrations exceeded the sulfate drinking water standard in sub-surface water on tailings amended with residue at 20 ton/acre, it does not appear that de-inking residue is a significant source of sulfur.

In July 1992, the effects of fertilization on plant growth were minimal because of the short time between plot establishment and the first measurement of vegetative cover. During this interval, a limited amount of plant growth would be expected as seed germination occurs and plants become established. De-inking residue negatively effected plant growth as the introduced species were established, although cool, wet conditions during this time may account for some initial slow growth rates.

The September 1992 vegetative cover estimates for introduced species indicate that the highest vegetative cover occurred on tailings fertilized at the two highest levels with residue amended at 20 ton/acre. Native species generally had the highest cover on tailings without residue at higher fertilizer levels. Low vegetative cover by native species would be expected since much of the plant growth during the first few years is in the development of an extensive root system.

In July 1993, the introduced species had the highest vegetative cover on tailings fertilized at the highest rates with residue applied at 10 ton/acre and 20 ton/acre. For native species, the highest vegetative cover occurred on tailings fertilized at the highest level without residue, and to a lesser degree, with residue applied at 10 ton/acre.

In September 1993, at the end of the second growing season, the introduced species had a 90 percent cover on tailings with fertilizer applied at $160 \mathrm{lb} /$ acre of nitrogen and $359 \mathrm{lb} / \mathrm{acre}$ of phosphorus $\left(\mathrm{P}_{2} \mathrm{O}_{5}\right)$ and with residue applied at 10 ton/acre. Alfalfa appeared to be the most abundant species on plots seeded with introduced species in September 1993. The highest 
vegetative cover occurred on residue amended tailings at 10 ton/acre and 20 ton/acre with fertilizer applied at the highest level. At the end of the second growing season, native species had the highest vegetative cover on tailings fertilized with $160 \mathrm{lb} /$ acre of nitrogen and 359 lb/acre phosphorus $\left(\mathrm{P}_{2} \mathrm{O}_{5}\right)$ and with residue amended at 0 ton/acre and 10 ton/acre. Although neither vegetative cover or biomass of specific plant species were measured on native treatments, Canada wild rye and kalm's brome appeared to be the most abundant species present.

At Eveleth Mines, vegetative cover for introduced species increased from no cover, prior to plot establishment, to 49 percent the first growing to 90 percent at the end of the second growing season on tailings fertilized at the highest level with 10 ton/acre of de-inking residue. At this same fertilizer and residue rate, vegetative cover for native plants increased from no cover before plot establishment, to 7 percent the first growing season to 69 percent at the end of the second growing season. Based upon this two-year study, the highest vegetative cover was achieved after two growing seasons using de-inking residue at 10 ton/acre with fertilizer applied at a high rate of application.

The plant analysis from 1992 was very limited but provided some preliminary information on the nutrient and metal content in alfalfa. In general, alfalfa had lower levels of boron, magnesium, manganese, and potassium on residue amended plots, but higher levels of calcium, zinc, and chloride on residue amended plots in 1992. Cadmium, chromium, nickel, and lead in alfalfa did not accumulate to toxic levels in October 1992.

The plant analysis for alfalfa in 1993 indicate that there were no significant differences in the nutrient and metal content due to fertilizer level (the control was excluded). However, there were significant differences in the levels of boron, magnesium, and manganese in alfalfa on residue amended plots. The levels of boron, magnesium, and manganese were typically lower in alfalfa grown on residue amended plots in 1993, as observed in 1992. Although not significantly different, relatively low mean phosphorus levels in alfalfa occurred on all treatments, but the highest phosphorus levels occurred on plots not amended with residue. Lower potassium levels in alfalfa occurred on residue amended plots, although not significant at the 0.05 level. The levels of cadmium, chromium, copper, nickel, lead, and zinc in alfalfa were not significantly different, which indicate that alfalfa did not accumulate these metals to toxic levels due to de-inking residue.

In bluestem, there were significant differences in the concentration of nutrients and metals in 1993 due to de-inking residue and fertilizer treatments. Significant differences in the levels of calcium, magnesium, manganese, and zinc in bluestem occurred due to de-inking residue. The calcium content in bluestem increased as the amount of residue applied increased to 40 ton/acre. Zinc levels in bluestem tended to increase with up to 20 ton/acre of de-inking residue. The levels of magnesium and manganese tended to decrease as the rate of de-inking residue increased up to 40 ton/acre. Cadmium, chromium, nickel, and lead in bluestem did not accumulate to toxic levels in September 1993. There were significant differences in the levels of potassium, magnesium, and phosphorus in bluestem due to fertilizer treatments. The potassium content in bluestem increased as the level of fertilization increased, probably due to synergistic effects of other nutrients applied using commercial fertilizer. The levels of magnesium and phosphorus in bluestem increased as the level of fertilization increased to the highest fertilizer rate. 


\section{RECOMMENDATIONS}

A continuation of monitoring the mineland reclamation research plots is recommended so that the third-year effects of de-inking residue on vegetation cover could be determined since the mineland rules specify a 90 percent ground cover be established on tailings after three growing seasons. The monitoring plan should include both an evaluation of vegetative cover and plant biomass on individual plots. The impacts of de-inking residue on the restoration of coarse tailings by native species may not be fully realized for 5 to 10 years.

Since a surrogate de-inking residue was used in this project, an evaluation of the SRFI residue should be made. The SRFI residue could be evaluated on larger plots, perhaps at rates of 10 ton/acre and 20 ton/acre, with commercial fertilizer or other nutrient source. The evaluation of SRFI residue should be done at two or more locations on the Iron Range. 


\section{LITERATURE CITED}

Dewar, S.W. 1987. Taconite tailing basins as a site for growing vegetation. In Proceedings 1987 Society of American Foresters Meeting (Minneapolis, Minnesota). Society of American Foresters.

Bailey, L.D. 1983. Effects of potassium fertilizer and fall harvests on alfalfa grown on the eastern Canada prairies. Can. J. Soil Sci. 63:211-218.

Chapman, H.D. 1967. Plant analysis values suggestive of nutrient status of selected crops. p. 77-92. In Soil testing and plant analysis. Part 2. SSSA Spec. Publ. 2. ASA, CSSA, and SSSA, Madison, WI.

Cornforth, J.S., and A.G. Sinclair. 1982. Fertilizer and lime recommendations for pastures and crops in New Zealand. Ministry Agric./Fisheries, Wellington, NZ.

Dewar, S.W. and E.R. Berglund. 1983. First year survival and growth of willow and poplar cuttings on taconite tailings in Minnesota. p. 141-148. In Proceedings of 1983 Symposium on Surface Mining, Hydrology, Sedimentology, and Reclamation (Lexington, Kentucky, November 28 - December 2, 1983). University of Kentucky. Lexington, Kentucky. 554 p.

Environmental Protection Agency. 1993. Standards for the use or disposal of sewage sludge: final rules. 40 CFR Parts 257,403 and 503. Federal Register/Vol 58, No.32/Friday, February 19, 1993. p 9248-9415.

Jones, J. B., Jr. 1972. Plant tissue analysis for micronutrients. p. 319-346. In Micronutrients in Agriculture. SSSA Publ. Madison, WI.

Jones, J. B., Jr. and V. W. Case. 1990. Sampling, handling, and analyzing plant tissue samples. p. 389-427. In R.L. Westerman (ed.) Soil testing and plant analysis. SSSA. Madison, WI.

Melchert, G.D., A.P. Eger, Z. Kassa, and S.W. Dewar. 1994. Reclaiming coarse taconite tailings with municipal solid waste compost. p. 175-183. In Proceedings 1994 International Land Reclamation and Mine Drainage Conference and the Third International Conference on the Abatement of Acidic Drainage, Pittsburgh, Pennsylvania, April 24-29, 1994.

Minnesota Department of Health. 1991. In Recommended allowable limits for drinking water contaminants. Release No. 3. p1-19

Minnesota Department of Natural Resources. 1980. Mineland Reclamation. Chapter 6130.0100-6130.6300. p 5694-5717.

Nelson, D.W. and L.E. Sommers. 1982. Total Carbon, Organic Carbon, and Organic Matter. p 539-579. In A.L. Page (ed.) Methods of Soil Analysis. Part 2. Amer. Soc. Agron., Madison, Wisconsin. 1159 p.

Nelson, W.L. and S.A. Barber. 1964. Nutrient deficiencies in legumes for grain and forage. p. 143-180. In H.B. Sprague (ed.) Hunger signs in crops. Davis McKey Co., New York. 
Norland, M.R. 1993. The effect of organic residues on the stabilization of coarse iron ore tailing materials. International Journal of Environmental Issues in Minerals and Energy Industry(1993):23-35.

Norland, M.R., D.L. Veith, and S.W. Dewar. 1991. Initial vegetative cover on coarse taconite tailing using organic amendments on Minnesota's Mesabi Iron Range. p. 263-277. In Proceedings 1991 National Meeting of the American Society for Surface Mining and Reclamation (Durango, Colorado, May 14-17, 1991). American Society for Surface Mining and Reclamation, Princeton, West Virginia. $721 \mathrm{p}$.

Norland, M.R., D.L. Veith, and S.W. Dewar. 1993. Standing crop biomass and cover on amended coarse taconite iron ore tailing. In Proceedings 1993 National Meeting of the American Society for Surface Mining and Reclamation (Spokane, Washington, May 16-19, 1993). American Society for Surface Mining and Reclamation, Spokane, Washington. p 385415.

Northeast Regional Research Publication. 1985. Criteria and recommendations for land application of sludges in the Northeast. Pennsylvania Agric. Exp. Stn. Bull. 851. Pierce, F.J. 1980. The content and distribution of $\mathrm{Cd}, \mathrm{Cr}, \mathrm{Cu}, \mathrm{Ni}, \mathrm{Pb}$, and $\mathrm{Zn}$ in 16 selected Minnesota soil series. M.S. Thesis. University of Minnesota, St. Paul, MN. 140 p.

Rehm,G., M.Schmitt, and R. Munter. 1993. Fertilizer recommendations for agronomic crops in Minnesota. Minnesota Extension Service, University of Minnesota. AG-BU6240.

Shetron,S.G. and R. Duffeck. 1970. Establishing vegetation on iron mine tailings. Journal of Soil and Water Conservation 25: 227-230.

Ulrich, A. 1976. Plant tissue analysis, plant analysis as a guide in fertilizing crops. p. 1-4. In H.M. Reisenauer (ed.) Soil and plant-tissue testing in California. Univ. of California Bull. 1879.

Van Lierop, W., Y.A. Martel, and M.P. Cescas. 1980. Optimal soil pH and sufficiency concentrations of $\mathrm{N}, \mathrm{P}$, and $\mathrm{K}$ for maximum alfalfa and onion yields on acid organic soils. Can. J. Soil Sci. 60:107-117.

Walker, W.M., D.W. Graffis, and C.D. Faulkner. 1987. Effect of potassium and boron upon yield and nutrient concentration of alfalfa. J. Plant Nutr. 10:2169-2180. 
Table 1.--Plant species and seeding rates used in the establishment of mineland reclamation plots at Eveleth Mines in May 1992.

\begin{tabular}{|c|c|c|c|}
\hline \multirow{2}{*}{$\begin{array}{l}\text { Plant Mix } \\
\text { Category }\end{array}$} & \multirow[b]{2}{*}{ Common and Scientific Names } & \multicolumn{2}{|c|}{ Seeding Rates } \\
\hline & & $\begin{array}{l}\text { lb/acre } \\
\text { of seed }\end{array}$ & $\begin{array}{c}\text { grams/plot of } \\
\text { PLS }\end{array}$ \\
\hline \multirow{5}{*}{$\begin{array}{l}\text { Native } \\
\text { species }\end{array}$} & $\begin{array}{l}\text { Big bluestem } \\
\text { (Andropogon gerardii) }\end{array}$ & 8 & 15.64 \\
\hline & $\begin{array}{l}\text { Little bluestem } \\
\text { (Schizachyrium scoparium) }\end{array}$ & 8 & 20.73 \\
\hline & $\begin{array}{l}\text { Kalm's brome } \\
\text { (Bromus kalmii) }\end{array}$ & 4 & 5.97 \\
\hline & $\begin{array}{l}\text { Canada wild rye } \\
\text { (Elymus canadensis) }\end{array}$ & 4 & 12.80 \\
\hline & $\begin{array}{l}\text { Bush clover } \\
\text { (Lespedeza capitata) }\end{array}$ & 3 & 4.31 \\
\hline \multirow{5}{*}{$\begin{array}{l}\text { Introduced } \\
\text { species }\end{array}$} & $\begin{array}{l}\text { Smooth bromegrass } \\
\text { (Bromus inermis) }\end{array}$ & 13 & 18.48 \\
\hline & $\begin{array}{l}\text { Red fescue } \\
\text { (Festuca rubra) }\end{array}$ & 7 & 8.98 \\
\hline & $\begin{array}{l}\text { Perennial ryegrass } \\
\text { (Lolium perenne) }\end{array}$ & 6 & 8.27 \\
\hline & $\begin{array}{l}\text { Alfalfa } \\
\text { (Medicago sativa) }\end{array}$ & 7 & 8.58 \\
\hline & $\begin{array}{l}\text { Buckwheat } \\
\text { (Fagopyrum esculentum) }\end{array}$ & 18 & 22.00 \\
\hline
\end{tabular}

${ }^{1}$ PLS $=$ Pure Live Seed or the weight of pure live seed contained in a seed lot. The Pure Live Seed is determined as follows: PLS $=$ (Germination Rate $\mathrm{X}$ Purity)/100. The dimensions of the "original" plots, before additional fertilizer was applied to the south half of each previously fertilized plot, was 2.5 by 4.0 meter. 
Table 2.--Mean chemical characteristics of coarse taconite tailings prior to the application of de-inking residue and fertilizer ${ }^{1}$.

\begin{tabular}{|l|c|c|}
\hline \multicolumn{1}{|c|}{ Properties, Unit } & Mean & Standard Deviation \\
\hline \hline Moisture, \% & 0.4 & 0.2 \\
\hline pH & 8.7 & 0.1 \\
\hline Conductivity, mmhos/cm & 0.5 & 0.3 \\
\hline Total Organic Carbon, \% & 0.98 & 0.05 \\
\hline Total Carbonate, \% & NA & NA \\
\hline Total Sulfur, \% & 0.04 & 0.02 \\
\hline Total Kjeldahl Nitrogen, \% & 0.01 & 0.00 \\
\hline Nitrate-Nitrogen, mg/kg & 0.6 & 0.3 \\
\hline Ammonium-Nitrogen, mg/kg & 6.4 & 2.6 \\
\hline C:N Ratio & 97.6 & 5.3 \\
\hline Organic Matter, \% & 0.96 & 0.11 \\
\hline CEC, meq/100 g & 2.0 & 0.1 \\
\hline Extractable & & \\
\hline Phosphorus, Olsen-P, ppm & 1.4 & 0.5 \\
\hline Chloride, ppm & NA & NA \\
\hline Sulfate-sulfur, ppm & 13 & 10 \\
\hline Iron, DTPA-ppm & 62.74 & 3.30 \\
\hline Copper, DTPA-ppm & 0.14 & 0.06 \\
\hline Zinc, DTPA-ppm & 0.13 & 0.06 \\
\hline Manganese, DTPA-ppm & 16.11 & 1.64 \\
\hline Boron, ppm & 0.1 & 0.00 \\
\hline Cadmium, DTPA-ppm & $<0.02$ & 0.24 \\
\hline Chromium, DTPA-ppm & 0.01 & 0.12 \\
\hline Nickel, DTPA-ppm & 0.45 & \\
\hline Lead, DTPA-ppm & & \\
\hline
\end{tabular}


Table 2.--Continued

\begin{tabular}{|c|c|c|}
\hline Properties, Unit & Mean & Standard Deviation \\
\hline \multicolumn{3}{|l|}{ Total (ppm) } \\
\hline Phosphorus & 228.11 & 32.77 \\
\hline Potassium & 537.67 & 36.92 \\
\hline Calcium & 8364.83 & 1161.95 \\
\hline Magnesium & 8487.05 & 645.03 \\
\hline Sodium & 93.71 & 39.01 \\
\hline Aluminum & 1456.18 & 82.67 \\
\hline Iron & 71186.85 & 7106.09 \\
\hline Manganese & 3489.04 & 469.74 \\
\hline Zinc & 12.42 & 1.51 \\
\hline Copper & 4.05 & 0.54 \\
\hline Boron & 17.99 & 1.33 \\
\hline Lead & 25.90 & 2.89 \\
\hline Nickel & 8.88 & 1.22 \\
\hline Chromium & 8.74 & 0.49 \\
\hline Cadmium & 7.86 & 0.75 \\
\hline
\end{tabular}

${ }^{1}$ Sample size $\mathrm{n}=5$ 
Table 3.--Mean chemical characteristics of de-inking residue ${ }^{1}$.

\begin{tabular}{|c|c|c|}
\hline Properties, Unit & Mean & Standard Deviation \\
\hline Moisture, \% & 67.3 & 0.3 \\
\hline $\mathrm{pH}$ & 8.2 & 0.2 \\
\hline Conductivity, mmhos/cm & 0.4 & 0.0 \\
\hline Total Organic Carbon, $\%$ & 25.84 & 1.27 \\
\hline Total Carbonate, $\%$ & 18.1 & 0.4 \\
\hline Total Sulfur, \% & 0.07 & 0.00 \\
\hline Total Kjeldahl Nitrogen, $\%$ & 0.21 & 0.03 \\
\hline Nitrate-Nitrogen, mg/kg & 1.4 & 0.2 \\
\hline Ammonium-Nitrogen, $\mathrm{mg} / \mathrm{kg}$ & NA & NA \\
\hline C:N Ratio & 123.0 & 17.6 \\
\hline Organic Matter ${ }^{2}, \%$ & 44.50 & 2.20 \\
\hline CEC, meq/100 g & 8.3 & 1.2 \\
\hline \multicolumn{3}{|l|}{ Extractable } \\
\hline Phosphorus, Olsen-P, ppm & 13.4 & 2.1 \\
\hline Chloride, ppm & 287.6 & 22.0 \\
\hline Sulfate-sulfur, ppm & 24.8 & 4.6 \\
\hline Iron, DTPA-ppm & 20.15 & 2.09 \\
\hline Copper, DTPA-ppm & 1.39 & 0.22 \\
\hline Zinc, DTPA-ppm & 12.07 & 1.68 \\
\hline Manganese, DTPA-ppm & 1.43 & 0.26 \\
\hline Boron, ppm & NA & NA \\
\hline Cadmium, DTPA-ppm & 0.22 & 0.11 \\
\hline Chromium, DTPA-ppm & 0.17 & 0.03 \\
\hline Nickel, DTPA-ppm & 0.48 & 0.07 \\
\hline Lead, DTPA-ppm & 1.87 & 1.00 \\
\hline
\end{tabular}


Table 3.--Continued

\begin{tabular}{|c|c|c|}
\hline Properties, Unit & Mean & Standard Deviation \\
\hline \multicolumn{3}{|l|}{ Total (ppm) } \\
\hline Phosphorus & 225.70 & 12.81 \\
\hline Potassium & 47.73 & 12.47 \\
\hline Calcium & 69214.60 & 5432.69 \\
\hline Magnesium & 659.13 & 31.37 \\
\hline Sodium & 132.18 & 12.27 \\
\hline Aluminum & 4451.18 & 263.31 \\
\hline Iron & 185.69 & 8.85 \\
\hline Manganese & 9.49 & 0.62 \\
\hline Zinc & 38.67 & 11.23 \\
\hline Copper & 3.12 & 0.23 \\
\hline Boron & 1.56 & 0.08 \\
\hline Lead & 2.84 & 0.96 \\
\hline Nickel & 1.28 & 0.67 \\
\hline Chromium & 4.89 & 0.27 \\
\hline Cadmium & 0.20 & 0.11 \\
\hline
\end{tabular}

${ }^{1}$ Sample size $\mathrm{n}=5$

${ }^{2}$ The percent organic matter was determined by multiplying total organic carbon by the Van Bemmelin factor of 1.724 
Table 4.--Chemical properties of coarse tailings amended with de-inking residue without commercial fertilizer where introduced species were planted in May 1992.

\begin{tabular}{|c|c|c|c|c|c|c|c|c|c|c|}
\hline & Col & & 10 tor & /acre & 20 ton & s/acre & 40 tor & s/acre & 80 tor & s/acre \\
\hline Units & 1992 & 1993 & 1992 & 1993 & 1992 & 1993 & 1992 & 1993 & 1992 & 1993 \\
\hline $\mathrm{pH}$ & 8.2 & 8.5 & 8.4 & 8.4 & 8.5 & 8.5 & 8.3 & 8.5 & 8.3 & 8.5 \\
\hline EC $1: 1, \mathrm{mmhos} / \mathrm{cm}$ & 0.1 & 0.1 & 0.1 & 0.1 & 0.1 & 0.1 & 0.1 & 0.1 & 0.1 & 0.1 \\
\hline Tot.Org. $N, \%$ & 0.00 & 0.01 & 0.01 & 0.01 & 0.01 & 0.01 & 0.01 & 0.01 & 0.01 & 0.01 \\
\hline Nitrate- $\mathrm{N}, \mathrm{mg} / \mathrm{kg}$ & 0.4 & 0.3 & 0.4 & 0.1 & 0.4 & 0.1 & 0.9 & 0.1 & 1.0 & 0.1 \\
\hline Ammonium- $\mathrm{N}, \mathrm{mg} / \mathrm{kg}$ & 0.1 & 0.1 & 0.1 & 0.1 & 0.1 & 0.1 & 3.2 & 0.1 & 0.2 & 0.1 \\
\hline Tot.Org.C, \% & 1.21 & 1.07 & 1.06 & 1.24 & 1.05 & 1.19 & 1.20 & 1.10 & 1.31 & 1.11 \\
\hline C:N Ratio & 403 & 107 & 212 & 124 & 175 & 119 & 100 & 110 & 187 & 111 \\
\hline Org. Matter, \% & 1.0 & 1.1 & 1.1 & 1.1 & 1.1 & 1.0 & 1.0 & 1.0 & 1.1 & 0.9 \\
\hline CEC, meq $/ 100 \mathrm{~g}$ & 1.9 & 1.8 & 1.9 & 1.7 & 1.9 & 1.8 & 1.9 & 1.7 & 1.8 & 1.7 \\
\hline Chloride, $\mathrm{mg} / \mathrm{kg}$ & 0.9 & 0.7 & 1.3 & 0.4 & 2.1 & 0.4 & 6.3 & 0.8 & 2.9 & 0.8 \\
\hline Extractable (mg/kg) & & & & & & & & & & \\
\hline Phosphorus & 2 & 1 & 2 & 1 & 2 & 1 & 8 & 1 & 2 & 1 \\
\hline Sulfate-S & 5 & 1 & 1 & 1 & 1 & 1 & 1 & 1 & 1 & 1 \\
\hline Iron & 59.01 & 55.45 & 50.33 & 56.78 & 50.09 & 46.81 & 37.82 & 38.28 & 41.57 & 41.07 \\
\hline Manganese & 14.89 & 13.37 & 13.09 & 12.45 & 14.98 & 12.40 & 8.00 & 7.45 & 9.90 & 8.59 \\
\hline Copper & 0.16 & 0.14 & 0.12 & 0.13 & 0.12 & 0.15 & 0.13 & 0.15 & 0.12 & 0.16 \\
\hline Zinc & 0.28 & 0.03 & 0.27 & 0.07 & 0.37 & 0.05 & 0.82 & 0.10 & 0.59 & 0.09 \\
\hline Cadmium & 0.03 & 0.01 & 0.02 & 0.01 & 0.02 & 0.01 & 0.02 & 0.01 & 0.02 & 0.01 \\
\hline Chromium & 0.08 & 0.03 & 0.05 & 0.03 & 0.05 & 0.03 & 0.05 & 0.03 & 0.04 & 0.03 \\
\hline Nickel & 0.09 & 0.04 & 0.09 & 0.04 & 0.09 & 0.04 & 0.29 & 0.04 & 0.09 & 0.04 \\
\hline Lead & 0.22 & 0.17 & 0.22 & 0.17 & 0.22 & 0.17 & 0.22 & 0.17 & 0.67 & 0.17 \\
\hline
\end{tabular}

${ }^{1}$ Control values represent the mean of two observations per year 
Table 5.--Chemical properties of coarse tailings amended with de-inking residue without commercial fertilizer where native species were planted in May 1992.

\begin{tabular}{|c|c|c|c|c|c|c|c|c|c|c|}
\hline \multirow[b]{2}{*}{ Units } & \multicolumn{2}{|c|}{ Control $^{1}$} & \multicolumn{2}{|c|}{10 tons/acre } & \multicolumn{2}{|c|}{20 tons/acre } & \multicolumn{2}{|c|}{40 tons/acre } & \multicolumn{2}{|c|}{80 tons/acre } \\
\hline & 1992 & 1993 & 1992 & 1993 & 1992 & 1993 & 1992 & 1993 & 1992 & 1993 \\
\hline $\mathrm{pH}$ & 8.3 & 8.6 & 8.2 & 8.5 & 8.3 & 8.5 & 8.3 & 8.5 & 8.2 & 8.5 \\
\hline $\mathrm{EC} 1: 1, \mathrm{mmhos} / \mathrm{cm}$ & 0.1 & 0.1 & 0.1 & 0.1 & 0.1 & 0.1 & 0.1 & 0.1 & 0.2 & 0.1 \\
\hline Tot.Org.N, \% & 0.00 & 0.01 & 0.01 & 0.01 & 0.00 & 0.01 & 0.01 & 0.01 & 0.04 & 0.01 \\
\hline Nitrate-N, mg/kg & 2.3 & 0.2 & 0.4 & 0.1 & 0.4 & 0.1 & 0.7 & 0.1 & 4.2 & 0.1 \\
\hline Ammonium- $\mathrm{N}, \mathrm{mg} / \mathrm{kg}$ & 0.1 & 0.3 & 1.1 & 0.3 & 0.1 & 0.2 & 0.1 & 0.2 & 0.1 & 0.3 \\
\hline Tot.Org.C, \% & 1.11 & 1.04 & 1.06 & 0.99 & 1.19 & 1.14 & 1.47 & 1.18 & 3.06 & 1.28 \\
\hline C:N Ratio & 247 & 104 & 177 & 99 & 397 & 114 & 294 & 118 & 75 & 128 \\
\hline Org. Matter, \% & 0.9 & 1.1 & 0.9 & 0.8 & 0.9 & 1.0 & 1.0 & 0.9 & 6.2 & 1.1 \\
\hline $\mathrm{CEC}, \mathrm{meq} / 100 \mathrm{~g}$ & 2.0 & 1.8 & 1.9 & 1.6 & 2.0 & 1.6 & 2.1 & 1.7 & 2.1 & 1.5 . \\
\hline Chloride, $\mathrm{mg} / \mathrm{kg}$ & 3.2 & 0.5 & 1.7 & 0.9 & 4.4 & 0.7 & 1.2 & 0.8 & 13.2 & 1.5 \\
\hline \multicolumn{11}{|l|}{ Extractable (mg/kg) } \\
\hline Phosphorus & 2 & 2 & 12 & 2 & 2 & 1 & 4 & 1 & 8 & 2 \\
\hline Sulfate-S & 4 & 1 & 1 & 1 & 1 & 1 & 1 & 1 & 24 & 1 \\
\hline Iron & 59.72 & 55.46 & 42.79 & 47.00 & 50.80 & 54.74 & 44.95 & 50.92 & 99.13 & 43.60 \\
\hline Manganese & 14.71 & 13.65 & 9.61 & 9.92 & 12.02 & 12.70 & 12.66 & 13.57 & 23.96 & 10.30 \\
\hline Copper & 0.18 & 0.21 & 0.14 & 0.23 & 0.17 & 0.25 & 0.16 & 0.12 & 0.60 & 0.24 \\
\hline Zinc & 0.64 & 0.04 & 0.36 & 0.12 & 0.19 & 0.08 & 0.32 & 0.08 & 45.78 & 0.20 \\
\hline Cadmium & 0.03 & 0.01 & 0.05 & 0.01 & 0.02 & 0.01 & 0.04 & 0.01 & 0.06 & 0.01 \\
\hline Chromium & 0.04 & 0.03 & 0.07 & 0.03 & 0.08 & 0.03 & 0.04 & 0.03 & 0.05 & 0.03 \\
\hline Nickel & 0.09 & 0.05 & 0.09 & 0.04 & 0.09 & 0.04 & 0.09 & 0.04 & 0.09 & 0.04 \\
\hline Lead & 0.68 & 0.17 & 1.23 & 0.17 & 0.84 & 0.17 & 0.26 & 0.17 & 0.26 & 0.17 \\
\hline
\end{tabular}

${ }^{1}$ Control values represent the mean of two observations per year 
Table 6.--Chemical properties of coarse tailings amended with de-inking residue with commercial fertilizer $\left(\mathrm{N}=160 \mathrm{lb} /\right.$ acre, $\left.\mathrm{P}_{2} \mathrm{O}_{5}=359 \mathrm{lb} / \mathrm{acre}\right)$ where introduced species were planted in May 1992.

\begin{tabular}{|c|c|c|c|c|c|c|c|c|c|c|}
\hline \multirow[b]{2}{*}{ Units } & \multirow{2}{*}{\multicolumn{2}{|c|}{ Fert. Control ${ }^{1}$}} & \multicolumn{2}{|c|}{10 tons/acre } & \multicolumn{2}{|c|}{20 tons/acre } & \multicolumn{2}{|c|}{40 tons/acre } & \multicolumn{2}{|c|}{80 tons/acre } \\
\hline & & & 1992 & 1993 & 1992 & 1993 & 1992 & 1993 & 1992 & 1993 \\
\hline $\mathrm{pH}$ & 8.2 & 8.4 & 8.3 & 8.3 & 8.2 & 8.2 & 8.1 & 8.3 & 8.1 & 8.3 \\
\hline EC $1: 1, \mathrm{mmhos} / \mathrm{cm}$ & 0.2 & 0.1 & 0.2 & 0.2 & 0.1 & 0.3 & 0.1 & 0.2 & 0.2 & 0.1 \\
\hline Tot.Org. N, \% & 0.00 & 0.01 & 0.01 & 0.01 & 0.01 & 0.01 & 0.01 & 0.01 & 0.03 & 0.01 \\
\hline Nitrate-N, mg/kg & 0.4 & 0.1 & 0.4 & 2.2 & 0.4 & 4.2 & 0.4 & 0.1 & 0.4 & 0.1 \\
\hline Ammonium- $\mathrm{N}, \mathrm{mg} / \mathrm{kg}$ & 0.5 & 0.1 & 0.9 & 0.3 & 1.7 & 0.6 & 0.7 & 0.6 & 0.4 & 0.3 \\
\hline Tot.Org.C, \% & 1.06 & 1.74 & 1.01 & 0.82 & 1.01 & 1.20 & 1.18 & 1.16 & 3.08 & 1.21 \\
\hline C:N Ratio & 236 & 174 & 112 & 82 & 72 & 120 & 107 & 116 & 99 & 121 \\
\hline Org. Matter, \% & 1.0 & 1.0 & 0.7 & 0.8 & 1.1 & 0.8 & 1.4 & 0.8 & 2.0 & 1.2 \\
\hline CEC, meq $/ 100 \mathrm{~g}$ & 1.8 & 1.9 & 1.7 & 1.9 & 1.9 & 1.9 & 1.9 & 2.1 & 1.9 & 2.0 \\
\hline Chloride, $\mathrm{mg} / \mathrm{kg}$ & 1.0 & 1.5 & 0.7 & 0.1 & 2.3 & 1.1 & 2.8 & 2.1 & 10.1 & 3.7 \\
\hline \multicolumn{11}{|l|}{ Extractable (mg/kg) } \\
\hline Phosphorus & 14 & 3 & 21 & 15 & 35 & 17 & 19 & 10 & 17 & 6 \\
\hline Sulfate-S & 8 & 1 & 2 & 10 & 2 & 4 & 1 & 3 & 16 & 1 \\
\hline Iron & 47.64 & 53.35 & 40.62 & 40.40 & 35.31 & 34.69 & 36.80 & 33.87 & 66.49 & 32.16 \\
\hline Manganese & 11.85 & 13.22 & 9.91 & 8.75 & 8.89 & 6.71 & 8.84 & 6.61 & 13.04 & 6.31 \\
\hline Copper & 0.16 & 0.13 & 0.18 & 0.13 & 0.15 & 0.13 & 0.16 & 0.15 & 0.34 & 0.21 \\
\hline Zinc & 0.20 & 0.10 & 0.27 & 0.11 & 0.40 & 0.18 & 0.42 & 0.33 & 7.85 & 0.57 \\
\hline Cadmium & 0.02 & 0.01 & 0.02 & 0.01 & 0.02 & 0.01 & 0.02 & 0.01 & 0.02 & 0.01 \\
\hline Chromium & 0.05 & 0.03 & 0.02 & 0.03 & 0.03 & 0.03 & 0.03 & 0.03 & 0.06 & 0.03 \\
\hline Nickel & 0.10 & 0.05 & 0.12 & 0.06 & 0.14 & 0.06 & 0.10 & 0.05 & 0.22 & 0.04 \\
\hline Lead & 0.61 & 0.17 & 0.39 & 0.17 & 0.39 & 0.17 & 0.64 & 0.17 & 1.16 & 0.17 \\
\hline
\end{tabular}

${ }^{1}$ Control values represent the mean of two observations per year 
Table 7.--Chemical properties of coarse tailings amended with de-inking residue with commercial fertilizer $\left(\mathrm{N}=160 \mathrm{lb} /\right.$ acre, $\mathrm{P}_{2} \mathrm{O}_{5}=359 \mathrm{lb} /$ acre $)$ where native species were planted in May 1992.

\begin{tabular}{|c|c|c|c|c|c|c|c|c|c|c|}
\hline \multirow[b]{2}{*}{ Units } & \multirow{2}{*}{\multicolumn{2}{|c|}{$\begin{array}{cc}\text { Fert. } & \text { Control }^{1} \\
1992 & 1993\end{array}$}} & \multicolumn{2}{|c|}{10 tons/acre } & \multicolumn{2}{|c|}{20 tons/acre } & \multicolumn{2}{|c|}{40 tons/acre } & \multicolumn{2}{|c|}{80 tons/acre } \\
\hline & & & 1992 & 1993 & 1992 & 1993 & 1992 & 1993 & 1992 & 1993 \\
\hline $\mathrm{pH}$ & 8.4 & 8.3 & 8.2 & 8.4 & 8.3 & 8.3 & 8.4 & 8.3 & 8.4 & 8.4 \\
\hline EC $1: 1, \mathrm{mmhos} / \mathrm{cm}$ & 0.1 & 0.1 & 0.1 & 0.1 & 0.1 & 0.1 & 0.1 & 0.1 & 0.2 & 0.1 \\
\hline Tot.Org.N, \% & 0.00 & 0.01 & 0.01 & 0.01 & 0.01 & 0.01 & 0.01 & 0.01 & 0.05 & 0.01 \\
\hline Nitrate-N, mg/kg & 0.4 & 0.1 & 0.4 & 0.4 & 0.4 & 0.2 & 0.4 & 0.1 & 0.4 & 0.1 \\
\hline Ammonium-N, mg/kg & 0.1 & 0.1 & 0.5 & 0.1 & 0.9 & 0.1 & 0.9 & 0.5 & 2.2 & 0.1 \\
\hline Tot.Org.C, \% & 1.13 & 1.06 & 1.29 & 1.20 & 1.08 & 1.50 & 0.90 & 1.15 & 3.11 & 1.11 \\
\hline C:N Ratio & 452 & 106 & 258 & 120 & 135 & 150 & 113 & 115 & 69 & 111 \\
\hline Org. Matter, \% & 0.9 & 1.0 & 0.8 & 1.0 & 0.7 & 0.8 & 0.7 & 0.8 & 4.5 & 1.0 \\
\hline $\mathrm{CEC}, \mathrm{meq} / 100 \mathrm{~g}$ & 1.9 & 1.9 & 2.0 & 2.0 & 2.1 & 2.1 & 1.9 & 2.0 & 2.3 & 1.8 \\
\hline Chloride, $\mathrm{mg} / \mathrm{kg}$ & 2.7 & 0.3 & 0.2 & 0.5 & 0.7 & 0.6 & 1.1 & 1.2 & 11.6 & 1.1 \\
\hline \multicolumn{11}{|l|}{ Extractable (mg/kg) } \\
\hline Phosphorus & 21 & 4 & 25 & 6 & 21 & 13 & 14 & 14 & 32 & 3 \\
\hline Sulfate-S & 4 & 1 & 1 & 3 & 1 & 3 & 1 & 3 & 22 & 3 \\
\hline Iron & 48.86 & 51.97 & 48.13 & 51.93 & 38.54 & 37.26 & 37.03 & 28.69 & 781.90 & 38.32 \\
\hline Manganese & 11.22 & 13.09 & 10.69 & 11.84 & 7.72 & 7.24 & 8.35 & 5.23 & 44.74 & 7.91 \\
\hline Copper & 0.14 & 0.12 & 0.15 & 0.11 & 0.16 & 0.11 & 0.12 & 0.15 & 0.67 & 0.11 \\
\hline Zinc & 0.20 & 0.04 & 0.61 & 0.88 & 0.50 & 0.18 & 0.38 & 0.46 & 12.53 & 0.22 \\
\hline Cadmium & 0.03 & 0.01 & 0.02 & 0.01 & 0.02 & 0.01 & 0.06 & 0.01 & 0.06 & 0.01 \\
\hline Chromium & 0.03 & 0.03 & 0.02 & 0.03 & 0.02 & 0.03 & 0.02 & 0.03 & 0.02 & 0.03 \\
\hline Nickel & 0.10 & 0.05 & 0.09 & 0.04 & 0.11 & 0.04 & 0.09 & 0.04 & 0.51 & 0.04 \\
\hline Lead & 0.35 & 0.17 & 0.22 & 0.17 & 0.22 & 0.17 & 0.22 & 0.17 & 1.37 & 0.17 \\
\hline
\end{tabular}

${ }^{1}$ Control values represent the mean of two observations per year 
Table 8.--The mean percent vegetative cover of introduced plant species measured in July 1992 at Eveleth Mines ${ }^{1}$.

\begin{tabular}{|c|c|c|c|c|c|}
\hline \multirow{2}{*}{$\begin{array}{l}\text { Fertilizer Rate } \\
\text { (lb/acre) }\end{array}$} & \multicolumn{5}{|c|}{$\begin{array}{l}\text { De-inking Residue Rate } \\
\text { (dry tons/acre) }\end{array}$} \\
\hline & 0 & 10 & 20 & 40 & 80 \\
\hline No fertilizer & $\begin{array}{l}11.1 \mathrm{a} \\
\pm 1.7\end{array}$ & $\begin{array}{l}4.4 \mathrm{~b} \\
\pm 7.7\end{array}$ & $\begin{array}{l}5.6 \mathrm{~b} \\
\pm 1.9\end{array}$ & $\begin{array}{l}7.8 \mathrm{ab} \\
\pm 6.9\end{array}$ & $\begin{array}{l}3.3 \mathrm{~b} \\
\pm 3.3\end{array}$ \\
\hline $\begin{array}{l}200 \mathrm{lb} / \text { acre } 18-46-0 \\
\mathrm{~N}=36 \quad \mathrm{P}_{2} \mathrm{O}_{5}=92\end{array}$ & $\begin{array}{r}17.2 \mathrm{a} \\
\pm 6.8 \\
\end{array}$ & $\begin{array}{l}14.4 b \\
\pm 9.6 \\
\end{array}$ & $\begin{array}{l}4.4 b \\
\pm 5.1 \\
\end{array}$ & $\begin{array}{l}10.0 \mathrm{ab} \\
\pm 3.3\end{array}$ & $\begin{array}{l}4.4 b \\
\pm 5.1 \\
\end{array}$ \\
\hline $\begin{array}{l}400 \mathrm{lb} / \mathrm{acre} 18-46-0 \\
\mathrm{~N}=72 \cdot \mathrm{P}_{2} \mathrm{O}_{5}=184\end{array}$ & $\begin{array}{r}18.3 \mathrm{a} \\
\pm 6.2 \\
\end{array}$ & $\begin{array}{l}3.3 \mathrm{~b} \\
\pm 5.8 \\
\end{array}$ & $\begin{array}{l}3.3 \mathrm{~b} \\
\pm 3.3 \\
\end{array}$ & $\begin{array}{l}7.8 \mathrm{~b} \\
\pm 5.1 \\
\end{array}$ & $\begin{array}{l}5.6 \mathrm{~b} \\
\pm 3.8 \\
\end{array}$ \\
\hline
\end{tabular}

${ }^{1}$ Mean percent vegetative cover \pm standard deviation. Sample sizes are as follows: control, with no residue or fertilizer $n=12$; treatments with residue only, no fertilizer $n=6$; treatments with fertilizer only, no residue $n=6$; treatments with residue and fertilizer $n=3$. Means within the same row followed by the same letter are not significantly different at the 0.05 level:

Table 9.--The mean percent vegetative cover of native plant species measured in $\underline{\text { uly }}$ 1992 at Eveleth Mines ${ }^{1}$.

\begin{tabular}{|l|c|c|c|c|c|}
\hline \multirow{2}{*}{$\begin{array}{l}\text { Fertilizer Rate } \\
\text { (lb/acre) }\end{array}$} & \multicolumn{5}{|c|}{$\begin{array}{c}\text { De-inking Residue Rate } \\
\text { (dry tons/acre) }\end{array}$} \\
\cline { 2 - 6 } & 0 & 10 & 20 & 40 & 80 \\
\hline \hline No fertilizer & $\begin{array}{c}1.7 \mathrm{a} \\
\pm 2.8\end{array}$ & $0.0 \mathrm{a}$ & $\begin{array}{c}1.1 \mathrm{a} \\
\pm 1.9\end{array}$ & $\begin{array}{c}1.1 \mathrm{a} \\
\pm 1.9\end{array}$ & $\begin{array}{c}2.2 \mathrm{a} \\
\pm 3.8\end{array}$ \\
\hline $200 \mathrm{lb} /$ acre $18-46-0$ & $\begin{array}{c}1.7 \mathrm{a} \\
\pm 1.8\end{array}$ & $0.0 \mathrm{a}$ & $0.0 \mathrm{a}$ & $0.0 \mathrm{a}$ & $\begin{array}{c}1.1 \mathrm{a} \\
\pm 1.9\end{array}$ \\
$\mathrm{~N}=36 \mathrm{P}_{2} \mathrm{O}_{5}=92$ & $\begin{array}{c}1.1 \mathrm{a} \\
\pm 1.7\end{array}$ & $\begin{array}{c}3.3 \mathrm{~b} \\
\pm 3.3\end{array}$ & $\begin{array}{c}2.2 \mathrm{ab} \\
\pm 3.8\end{array}$ & $\begin{array}{c}1.1 \mathrm{ab} \\
\pm 1.9\end{array}$ & $\begin{array}{c}4.4 \mathrm{bc} \\
\pm 3.8\end{array}$ \\
\hline $400 \mathrm{lb} / \mathrm{acre} 18-46-0$ & & &
\end{tabular}

${ }^{1}$ Mean percent vegetative cover \pm standard deviation. Sample sizes are as follows: control, with no residue or fertilizer $n=12$; treatments with residue only, no fertilizer $n=6$; treatments with fertilizer only, no residue $n=6$; treatments with residue and fertilizer $n=3$. Means within the same row followed by the same letter are not significantly different at the 0.05 level. 
Table 10.--The mean percent vegetative cover of introduced plant species measured in September 1992 at Eveleth Mines ${ }^{1}$.

\begin{tabular}{|c|c|c|c|c|c|}
\hline \multirow{2}{*}{$\begin{array}{l}\text { Fertilizer Rate } \\
\text { (lb/acre) }\end{array}$} & \multicolumn{5}{|c|}{$\begin{array}{l}\text { De-inking Residue Rate } \\
\text { (dry tons/acre) }\end{array}$} \\
\hline & 0 & 10 & 20 & 40 & 80 \\
\hline No fertilizer & $\begin{array}{l}5.8 \mathrm{a} \\
\pm 4.1 \\
\end{array}$ & $0.0 \mathrm{a}$ & $\begin{array}{l}2.2 \mathrm{a} \\
\pm 1.7 \\
\end{array}$ & $\begin{array}{l}1.7 \mathrm{a} \\
\pm 1.8 \\
\end{array}$ & $\begin{array}{l}3.9 \mathrm{a} \\
\pm 2.5 \\
\end{array}$ \\
\hline $\begin{array}{l}200 \mathrm{lb} / \text { acre } 18-46-0 \\
\mathrm{~N}=36 \quad \mathrm{P}_{2} \mathrm{O}_{5}=92\end{array}$ & $\begin{array}{r}21.1 \mathrm{a} \\
\pm 7.5 \\
\end{array}$ & $\begin{array}{r}26.7 \mathrm{a} \\
\pm 8.8 \\
\end{array}$ & $\begin{array}{l}30.0 \mathrm{ab} \\
\pm 11.5 \\
\end{array}$ & $\begin{array}{r}24.4 \mathrm{a} \\
\pm 1.9 \\
\end{array}$ & $\begin{array}{l}6.7 \mathrm{ac} \\
\pm 0.0 \\
\end{array}$ \\
\hline $\mathrm{N}=80 \quad \mathrm{P}_{2} \mathrm{O}_{5}=180$ & $\begin{array}{l}37.8 \mathrm{a} \\
\pm 14.6 \\
\end{array}$ & $\begin{array}{l}25.6 \mathrm{ab} \\
\pm 15.0 \\
\end{array}$ & $\begin{array}{l}42.2 \mathrm{ab} \\
\pm 15.8 \\
\end{array}$ & $\begin{array}{c}20.0 \mathrm{abc} \\
\pm 5.8 \\
\end{array}$ & $\begin{array}{r}12.2 \mathrm{bc} \\
\pm 10.2 \\
\end{array}$ \\
\hline $\begin{array}{l}400 \mathrm{lb} / \text { acre } 18-46-0 \\
\mathrm{~N}=72 \quad \mathrm{P}_{2} \mathrm{O}_{5}=184\end{array}$ & $\begin{array}{c}33.9 \mathrm{a} \\
\pm 11.0 \\
\end{array}$ & $\begin{array}{r}48.9 \mathrm{a} \\
\pm 20.1 \\
\end{array}$ & $\begin{array}{r}50.0 \mathrm{a} \\
\pm 28.5 \\
\end{array}$ & $\begin{array}{r}30.0 \mathrm{ab} \\
\pm 20.8 \\
\end{array}$ & $\begin{array}{l}10.0 \mathrm{~b} \\
\pm 8.8 \\
\end{array}$ \\
\hline $\mathrm{N}=160 \quad \mathrm{P}_{2} \mathrm{O}_{5}=359$ & $\begin{array}{c}49.4 \mathrm{a} \\
\pm 13.4\end{array}$ & $\begin{array}{l}48.9 \mathrm{a} \\
\pm 5.1\end{array}$ & $\begin{array}{l}50.0 \mathrm{a} \\
\pm 5.8\end{array}$ & $\begin{array}{l}34.4 \mathrm{ab} \\
\pm 20.1\end{array}$ & $\begin{array}{l}15.6 \mathrm{~b} \\
\pm 8.4\end{array}$ \\
\hline
\end{tabular}

${ }^{1}$ Mean percent vegetative cover \pm standard deviation. Sample sizes are as follows: control, with no residue or fertilizer $n=12$; treatments with residue only, no fertilizer $n=6$; treatments with fertilizer only, no residue $n=6$; treatments with residue and fertilizer $n=3$. Means within the same row followed by the same letter are not significantly different at the 0.05 level. 
Table 11.--The mean percent vegetative cover of native plant species measured in September 1992 at Eveleth Mines ${ }^{1}$.

\begin{tabular}{|c|c|c|c|c|c|}
\hline \multirow{2}{*}{$\begin{array}{l}\text { Fertilizer Rate } \\
\text { (lb/acre) }\end{array}$} & \multicolumn{5}{|c|}{$\begin{array}{l}\text { De-inking Residue Rate } \\
\text { (dry tons/acre) }\end{array}$} \\
\hline & 0 & 10 & 20 & 40 & 80 \\
\hline No fertilizer & $\begin{array}{l}3.6 \mathrm{a} \\
\pm 3.3\end{array}$ & $\begin{array}{l}1.7 \mathrm{a} \\
\pm 1.8\end{array}$ & $\begin{array}{l}1.1 \mathrm{a} \\
\pm 1.7 \\
\end{array}$ & $\begin{array}{r}0.6 \mathrm{a} \\
\pm 1.4 \\
\end{array}$ & $\begin{array}{l}1.1 \mathrm{a} \\
\pm 1.7 \\
\end{array}$ \\
\hline $\begin{array}{l}200 \mathrm{lb} / \mathrm{acre} 18-46-0 \\
\mathrm{~N}=36 \quad \mathrm{P}_{2} \mathrm{O}_{5}=92\end{array}$ & $\begin{array}{l}10.0 \mathrm{a} \\
\pm 3.7 \\
\end{array}$ & $\begin{array}{l}1.1 \mathrm{~b} \\
\pm 1.9 \\
\end{array}$ & $\begin{array}{l}2.2 \mathrm{ab} \\
\pm 1.9 \\
\end{array}$ & $0.0 \mathrm{~b}$ & $0.0 \mathrm{~b}$ \\
\hline $\mathrm{N}=80 \quad \mathrm{P}_{2} \mathrm{O}_{5}=180$ & $\begin{array}{c}5.6 \mathrm{a} \\
\pm 6.2 \\
\end{array}$ & $\begin{array}{l}1.1 \mathrm{a} \\
\pm 1.9 \\
\end{array}$ & $\begin{array}{l}1.1 \mathrm{a} \\
\pm 1.9 \\
\end{array}$ & $\begin{array}{l}1.1 \mathrm{a} \\
\pm 1.9 \\
\end{array}$ & $\begin{array}{r}1.1 \mathrm{a} \\
\pm 1.9 \\
\end{array}$ \\
\hline $\begin{array}{l}400 \mathrm{lb} / \mathrm{acre} 18-46-0 \\
\mathrm{~N}=72 \quad \mathrm{P}_{2} \mathrm{O}_{5}=184\end{array}$ & $\begin{array}{r}14.4 \mathrm{a} \\
\pm 11.7 \\
\end{array}$ & $\begin{array}{l}1.1 \mathrm{~b} \\
\pm 1.9 \\
\end{array}$ & $\begin{array}{r}3.3 \mathrm{~b} \\
\pm 3.3 \\
\end{array}$ & $\begin{array}{l}2.2 \mathrm{~b} \\
\pm 1.9 \\
\end{array}$ & $0.0 \mathrm{~b}$ \\
\hline $\mathrm{N}=160 \quad \mathrm{P}_{2} \mathrm{O}_{5}=359$ & $\begin{array}{l}11.7 \mathrm{a} \\
\pm 12.4\end{array}$ & $\begin{array}{l}6.7 \mathrm{ab} \\
\pm 8.8\end{array}$ & $\begin{array}{l}1.1 \mathrm{~b} \\
\pm 1.9\end{array}$ & $\begin{array}{l}1.1 \mathrm{~b} \\
\pm 1.9\end{array}$ & $0.0 \mathrm{~b}$ \\
\hline
\end{tabular}

${ }^{1}$ Mean percent vegetative cover \pm standard deviation. Sample sizes are as follows: control, with no residue or fertilizer $n=12$; treatments with residue only, no fertilizer $n=6$; treatments with fertilizer only, no residue $n=6$; treatments with residue and fertilizer $n=3$. Means within the same row followed by the same letter are not significantly different at the 0.05 level. 
Table 12.--The mean percent vegetative cover of introduced plant species measured in July 1993 at Eveleth Mines ${ }^{1}$.

\begin{tabular}{|c|c|c|c|c|c|}
\hline \multirow{2}{*}{$\begin{array}{l}\text { Fertilizer Rate } \\
\text { (lb/acre) }\end{array}$} & \multicolumn{5}{|c|}{$\begin{array}{l}\text { De-inking Residue Rate } \\
\text { (dry tons/acre) }\end{array}$} \\
\hline & 0 & 10 & 20 & 40 & 80 \\
\hline No fertilizer & $\begin{array}{l}3.9 \mathrm{a} \\
\pm 3.7\end{array}$ & $0.0 \mathrm{a}$ & $\begin{array}{l}1.7 \mathrm{a} \\
\pm 1.8\end{array}$ & $\begin{array}{l}1.1 \mathrm{a} \\
\pm 2.7\end{array}$ & $\begin{array}{l}0.6 \mathrm{a} \\
\pm 1.4\end{array}$ \\
\hline $\begin{array}{l}200 \mathrm{lb} / \mathrm{acre} 18-46-0 \\
\mathrm{~N}=36 \quad \mathrm{P}_{2} \mathrm{O}_{5}=92\end{array}$ & $\begin{array}{r}18.3 \mathrm{a} \\
\pm 7.8\end{array}$ & $\begin{array}{l}60.0 \mathrm{~b} \\
\pm 8.8\end{array}$ & $\begin{array}{l}53.3 \mathrm{~b} \\
\pm 5.8\end{array}$ & $\begin{array}{l}40.0 \mathrm{~b} \\
\pm 15.3\end{array}$ & $\begin{array}{l}8.9 \mathrm{a} \\
\pm 6.9\end{array}$ \\
\hline $\mathrm{N}=80 \quad \mathrm{P}_{2} \mathrm{O}_{5}=180$ & $\begin{array}{l}27.2 \mathrm{a} \\
\pm 16.5 \\
\end{array}$ & $\begin{array}{r}48.9 \mathrm{~b} \\
\pm 16.4 \\
\end{array}$ & $\begin{array}{r}55.6 \mathrm{~b} \\
\pm 10.2 \\
\end{array}$ & $\begin{array}{l}44.4 \mathrm{ab} \\
\pm 12.6 \\
\end{array}$ & $\begin{array}{r}16.7 \mathrm{ac} \\
\pm 8.8 \\
\end{array}$ \\
\hline $\begin{array}{l}400 \text { lb/acre } 18-46-0 \\
\mathrm{~N}=72 \quad \mathrm{P}_{2} \mathrm{O}_{5}=184\end{array}$ & $\begin{array}{l}24.4 \mathrm{a} \\
\pm 8.1\end{array}$ & $\begin{array}{l}65.6 \mathrm{~b} \\
\pm 8.4\end{array}$ & $\begin{array}{l}61.1 \mathrm{~b} \\
\pm 18.4\end{array}$ & $\begin{array}{l}55.6 \mathrm{~b} \\
\pm 30.1\end{array}$ & $\begin{array}{l}21.1 \mathrm{a} \\
\pm 13.5\end{array}$ \\
\hline $\mathrm{N}=160 \quad \mathrm{P}_{2} \mathrm{O}_{5}=359$ & $\begin{array}{c}40.6 \mathrm{a} \\
\pm 17.3\end{array}$ & $\begin{array}{l}67.8 \mathrm{~b} \\
\pm 5.1\end{array}$ & $\begin{array}{l}60.0 \mathrm{~b} \\
\pm 11.5\end{array}$ & $\begin{array}{l}55.6 \mathrm{ab} \\
\pm 20.1 \\
\end{array}$ & $\begin{array}{l}26.7 \mathrm{ac} \\
\pm 18.6\end{array}$ \\
\hline
\end{tabular}

${ }^{1}$ Mean percent vegetative cover \pm standard deviation. Sample sizes are as follows: control, with no residue or fertilizer $n=12$; treatments with residue only, no fertilizer $n=6$; treatments with fertilizer only, no residue $n=6$; treatments with residue and fertilizer $n=3$. Means within the same row followed by the same letter are not significantly different at the 0.05 level. 
Table 13.--The mean percent vegetative cover of native plant species measured in July 1993 at Eveleth Mines'.

\begin{tabular}{|l|c|c|c|c|c|}
\hline \multirow{2}{*}{$\begin{array}{l}\text { Fertilizer Rate } \\
\text { (lb/acre) }\end{array}$} & \multicolumn{5}{|c|}{$\begin{array}{c}\text { De-inking Residue Rate } \\
\text { (dry tons/acre) }\end{array}$} \\
\cline { 2 - 6 } & 0 & 10 & 20 & 40 & 80 \\
\hline \hline & $\begin{array}{c}3.3 \mathrm{a} \\
\pm 4.7\end{array}$ & $0.0 \mathrm{a}$ & $\begin{array}{c}0.6 \mathrm{a} \\
\pm 1.4\end{array}$ & $\begin{array}{c}1.1 \mathrm{a} \\
\pm 1.7\end{array}$ & $\begin{array}{c}0.6 \mathrm{a} \\
\pm 1.4\end{array}$ \\
\hline No fertilizer & $\begin{array}{c}11.7 \mathrm{a} \\
\pm 11.3\end{array}$ & $\begin{array}{c}1.1 \mathrm{ac} \\
\pm 1.9\end{array}$ & $0.0 \mathrm{bc}$ & $0.0 \mathrm{bc}$ & $0.0 \mathrm{bc}$ \\
$\mathrm{N}=36 \quad \mathrm{P}_{2} \mathrm{O}_{5}=92$ & $\begin{array}{c}13.3 \mathrm{a} \\
\pm 13.5\end{array}$ & $\begin{array}{c}14.4 \mathrm{a} \\
\pm 1.9\end{array}$ & $\begin{array}{c}1.1 \mathrm{~b} \\
\pm 1.9\end{array}$ & $0.0 \mathrm{~b}$ & $\begin{array}{c}2.2 \mathrm{~b} \\
\pm 3.8\end{array}$ \\
\hline $\mathrm{N}=80 \mathrm{P}_{2} \mathrm{O}_{5}=180$ & $\begin{array}{c}16.1 \mathrm{a} \\
\pm 12.5\end{array}$ & $\begin{array}{c}4.4 \mathrm{~b} \\
\pm 7.7\end{array}$ & $\begin{array}{c}3.3 \mathrm{~b} \\
\pm 5.8\end{array}$ & $0.0 \mathrm{~b}$ & $\begin{array}{c}1.1 \mathrm{~b} \\
\pm 1.9\end{array}$ \\
\hline $400 \mathrm{lb} / \mathrm{acre} 18-46-0$ & $\begin{array}{c}22.8 \mathrm{a} \\
\pm 7.7\end{array}$ & $\begin{array}{c}27.8 \mathrm{ab} \\
\pm 17.1\end{array}$ & $\begin{array}{c}14.4 \mathrm{ac} \\
\pm 13.5\end{array}$ & $\begin{array}{c}1.1 \mathrm{~d} \\
\pm 1.9\end{array}$ & $\begin{array}{c}1.1 \mathrm{~d} \\
\pm 1.9\end{array}$ \\
\hline
\end{tabular}

${ }^{1}$ Mean percent vegetative cover \pm standard deviation. Sample sizes are as follows: control, with no residue or fertilizer $n=12$; treatments with residue only, no fertilizer $n=6$; treatments with fertilizer only, no residue $n=6$; treatments with residue and fertilizer $n=3$. Means within the same row followed by the same letter are not significantly different at the 0.05 level. 
Table 14.--The mean percent vegetative cover of introduced plant species measured in September 1993 at Eveleth Mines'

\begin{tabular}{|l|c|c|c|c|c|}
\hline \multirow{2}{*}{$\begin{array}{l}\text { Fertilizer Rate } \\
\text { (lb/acre) }\end{array}$} & \multicolumn{5}{|c|}{$\begin{array}{c}\text { De-inking Residue Rate } \\
\text { (dry tons/acre) }\end{array}$} \\
\cline { 2 - 7 } & 0 & 10 & 20 & 40 & 80 \\
\hline & $\begin{array}{c}11.7 \mathrm{a} \\
\text { No fertilizer }\end{array}$ & $\begin{array}{c}0.6 \mathrm{~b} \\
\pm 5.6\end{array}$ & $\begin{array}{c}1.1 \mathrm{~b} \\
\pm 1.4\end{array}$ & $\begin{array}{c}4.4 \mathrm{ab} \\
\pm 1.7\end{array}$ & $\begin{array}{c}0.6 \mathrm{~b} \\
\pm 9.3\end{array}$ \\
\hline $200 \mathrm{lb} /$ acre $18-46-0$ & $32.8 \mathrm{a}$ & $60.0 \mathrm{~b}$ & $54.4 \mathrm{~b}$ & $46.7 \mathrm{ab}$ & $\begin{array}{c}24.4 \mathrm{ac} \\
\pm 5.3\end{array}$ \\
$\mathrm{~N}=36 \quad \mathrm{P}_{2} \mathrm{O}_{5}=92$ & \pm 5.3 & \pm 6.7 & \pm 1.9 & \pm 15.3 & \pm 5.1 \\
\hline & $61.1 \mathrm{a}$ & $65.6 \mathrm{a}$ & $75.6 \mathrm{ab}$ & $53.3 \mathrm{ac}$ & $\begin{array}{c}22.2 \mathrm{~d} \\
\pm 6.9\end{array}$ \\
$\mathrm{~N}=80 \quad \mathrm{P}_{2} \mathrm{O}_{5}=180$ & \pm 12.4 & \pm 1.9 & \pm 6.9 & \pm 16.7 & \pm 6.9 \\
\hline $400 \mathrm{lb} / \mathrm{acre} 18-46-0$ & $49.4 \mathrm{a}$ & $75.6 \mathrm{~b}$ & $67.8 \mathrm{bc}$ & $56.7 \mathrm{ac}$ & $32.2 \mathrm{~d}$ \\
$\mathrm{~N}=72 \mathrm{P}_{2} \mathrm{O}_{5}=184$ & \pm 9.3 & \pm 8.4 & \pm 24.6 & \pm 15.3 & \pm 15.4 \\
\hline & $77.2 \mathrm{a}$ & $90.0 \mathrm{a}$ & $86.7 \mathrm{a}$ & $75.6 \mathrm{a}$ & $44.4 \mathrm{~b}$ \\
$\mathrm{~N}=160 \quad \mathrm{P}_{2} \mathrm{O}_{5}=359$ & \pm 17.2 & \pm 5.8 & \pm 11.5 & \pm 9.6 & \pm 15.0 \\
\hline
\end{tabular}

${ }^{1}$ Mean percent vegetative cover \pm standard deviation. Sample sizes are as follows: control, with no residue or fertilizer $n=12$; treatments with residue only, no fertilizer $n=6$; treatments with fertilizer only, no residue $n=6$; treatments with residue and fertilizer $n=3$. Means within the same row followed by the same letter are not significantly different at the 0.05 level. 
Table 15.--The mean percent vegetative cover of native plant species measured in September 1993 at Eveleth Mines ${ }^{1}$.

\begin{tabular}{|c|c|c|c|c|c|}
\hline \multirow{2}{*}{$\begin{array}{l}\text { Fertilizer Rate } \\
\text { (lb/acre) }\end{array}$} & \multicolumn{5}{|c|}{$\begin{array}{l}\text { De-inking Residue Rate } \\
\text { (dry tons/acre) }\end{array}$} \\
\hline & 0 & 10 & 20 & 40 & 80 \\
\hline No fertilizer & $\begin{array}{l}12.2 \mathrm{a} \\
\pm 8.2\end{array}$ & $\begin{array}{l}7.8 \mathrm{ab} \\
\pm 6.2\end{array}$ & $\begin{array}{l}5.0 \mathrm{ab} \\
\pm 6.2\end{array}$ & $\begin{array}{l}2.2 \mathrm{~b} \\
\pm 1.7\end{array}$ & $\begin{array}{l}2.2 \mathrm{~b} \\
\pm 2.7\end{array}$ \\
\hline $\begin{array}{l}200 \mathrm{lb} / \text { acre } 18-46-0 \\
\mathrm{~N}=36 \quad \mathrm{P}_{2} \mathrm{O}_{5}=92\end{array}$ & $\begin{array}{l}29.4 \mathrm{a} \\
\pm 13.7\end{array}$ & $\begin{array}{l}6.7 \mathrm{~b} \\
\pm 5.8\end{array}$ & $\begin{array}{l}5.6 \mathrm{~b} \\
\pm 6.9\end{array}$ & $0.0 \mathrm{~b}$ & $\begin{array}{l}1.1 \mathrm{~b} \\
\pm 1.9\end{array}$ \\
\hline $\mathrm{N}=80 \quad \mathrm{P}_{2} \mathrm{O}_{5}=180$ & $\begin{array}{l}37.2 \mathrm{a} \\
\pm 18.9 \\
\end{array}$ & $\begin{array}{l}36.7 \mathrm{a} \\
\pm 5.8 \\
\end{array}$ & $\begin{array}{c}12.2 \mathrm{~b} \\
\pm 12.6 \\
\end{array}$ & $\begin{array}{l}4.4 \mathrm{~b} \\
\pm 5.1 \\
\end{array}$ & $\begin{array}{l}2.2 \mathrm{~b} \\
\pm 1.9 \\
\end{array}$ \\
\hline $\begin{array}{l}400 \text { lb/acre } 18-46-0 \\
\mathrm{~N}=72 \quad \mathrm{P}_{2} \mathrm{O}_{5}=184\end{array}$ & $\begin{array}{l}36.1 \mathrm{a} \\
\pm 16.5 \\
\end{array}$ & $\begin{array}{l}20.0 \mathrm{~b} \\
\pm 20.8 \\
\end{array}$ & $\begin{array}{l}18.9 b \\
\pm 24.1 \\
\end{array}$ & $\begin{array}{l}5.6 \mathrm{~b} \\
\pm 1.9\end{array}$ & $\begin{array}{l}2.2 \mathrm{~b} \\
\pm 1.9\end{array}$ \\
\hline $\mathrm{N}=160 \quad \mathrm{P}_{2} \mathrm{O}_{5}=359$ & $\begin{array}{l}54.4 \mathrm{a} \\
\pm 12.4\end{array}$ & $\begin{array}{l}68.9 \mathrm{a} \\
\pm 11.7\end{array}$ & $\begin{array}{l}41.1 \mathrm{ab} \\
\pm 20.4\end{array}$ & $\begin{array}{l}32.2 \mathrm{bc} \\
\pm 11.7\end{array}$ & $\begin{array}{l}2.2 \mathrm{~d} \\
\pm 1.9\end{array}$ \\
\hline
\end{tabular}

${ }^{1}$ Mean percent vegetative cover \pm standard deviation. Sample sizes are as follows: control, with no residue or fertilizer $n=12$; treatments with residue only, no fertilizer $n=6$; treatments with fertilizer only, no residue $n=6$; treatments with residue and fertilizer $n=3$. Means within the same row followed by the same letter are not significantly different at the 0.05 level. 
Table 16.--Published critical values for alfalfa grown in pure stands for whole plants and phytotoxic levels of cadmium, chromium, nickel, and lead that can occur in plants.

\begin{tabular}{|c|c|c|c|c|c|}
\hline \multirow{2}{*}{$\begin{array}{l}\text { Chemical } \\
\text { Fraction }\end{array}$} & \multicolumn{4}{|c|}{ Critical and Toxic Levels } & \multirow[b]{2}{*}{ Reference } \\
\hline & Deficient & Critical & Adequate & High/Toxic & \\
\hline $\begin{array}{l}\text { Total Kjeldahl } \\
\text { Nitrogen (\%) }\end{array}$ & - & 2.0 & - & - & $\begin{array}{l}\text { Van Lierop et al., } \\
1980\end{array}$ \\
\hline \multicolumn{6}{|l|}{ Total $\mathrm{mg} / \mathrm{kg}$} \\
\hline Phosphorus & 1,800 & - & $\begin{array}{c}2,000 \\
5,000\end{array}$ & & Chapman, 1967 \\
\hline Potassium & $<10,000$ & 22,000 & - & - & $\begin{array}{l}\text { Bailey, } 1983 \\
\text { Walker et al., } 1987\end{array}$ \\
\hline Calcium & - & 18,000 & 22,000 & - & $\begin{array}{l}\text { Nelson \& Berber, } \\
1964\end{array}$ \\
\hline Magnesium & $<2,000$ & 2,500 & - & - & Chapman, 1967 \\
\hline Boron & $<15$ & 20 & $>20$ & - & Chapman, 1967 \\
\hline Manganese & $<10$ & - & $>15$ & - & Chapman, 1967 \\
\hline Iron & $<40$ & $40-44$ & $45-60$ & $>60$ & $\begin{array}{l}\text { Cornforth \& Sinclair, } \\
1982\end{array}$ \\
\hline Zinc & $<15$ & - & $20-50$ & - & Chapman, 1967 \\
\hline Copper & $<5$ & - & $5-16$ & - & Chapman, 1967 \\
\hline Cadmium & - & - & - & $>1$ & $\begin{array}{l}\text { Northeast Regional } \\
\text { Research Publ., } 1985\end{array}$ \\
\hline Chromium & - & - & - & $>2$ & $\begin{array}{l}\text { Northeast Regional } \\
\text { Research Publ., } 1985\end{array}$ \\
\hline Nickel & - & - & - & $>3$ & $\begin{array}{l}\text { Northeast Regional } \\
\text { Research Publ., } 1985\end{array}$ \\
\hline Lead & - & - & - & $>10$ & $\begin{array}{l}\text { Northeast Regional } \\
\text { Research Publ., } 1985\end{array}$ \\
\hline
\end{tabular}




\begin{tabular}{|c|c|c|c|c|c|c|c|c|c|c|c|c|c|c|c|c|c|c|c|c|}
\hline \multicolumn{3}{|c|}{ Treatments } & \multicolumn{18}{|c|}{ Chemical Analyses } \\
\hline Residue & $\mathrm{N}$ & $\mathrm{P}_{2} \mathrm{O}_{5}$ & $\mathrm{TKN}$ & $\mathrm{Cl}$ & $\mathrm{NO}_{3}$ & $\mathrm{Ca}$ & $\mathrm{Mg}$ & $\mathrm{Na}$ & $\mathrm{K}$ & $\mathbf{P}$ & $\mathrm{Fe}$ & $\mathrm{Al}$ & $\mathrm{Mn}$ & $\mathrm{Cu}$ & $\mathrm{Zn}$ & B & $\mathrm{Cd}$ & $\mathrm{Cr}$ & $\mathrm{Ni}$ & $\mathrm{Pb}$ \\
\hline tons/ac & $\mathrm{Ib} / \mathrm{ac}$ & $\mathrm{lb} / \mathrm{ac}$ & $\%$ & $\mathrm{ppm}$ & $\mathrm{ppm}$ & $\mathrm{ppm}$ & $\mathrm{ppm}$ & $\mathrm{ppm}$ & $\mathrm{ppm}$ & $\mathrm{ppm}$ & $\mathrm{ppm}$ & $\mathrm{ppm}$ & $\mathrm{ppm}$ & $\mathrm{ppm}$ & $\mathrm{ppm}$ & $\mathrm{ppm}$ & $\mathrm{ppm}$ & $\mathrm{ppm}$ & $\mathrm{ppm}$ & $\mathrm{ppm}$ \\
\hline 0 & 72 & 184 & 3.1 & 1262 & 21 & 27479 & 13927 & 286 & 25505 & 1898 & 833 & 101 & 488 & 5.9 & 6.1 & 84.1 & 0.33 & 1.3 & 3.0 & 5.1 \\
\hline 0 & 160 & 359 & 3.4 & 1314 & 167 & 21180 & 10559 & 300 & 30636 & 3061 & 813 & 90 & 467 & 7.1 & 6.8 & 63.4 & 0.68 & 1.5 & 4.9 & 6.3 \\
\hline 10 & 72 & 184 & 2.9 & 4045 & 27 & 26895 & 5874 & 325 & 20732 & 1393 & 446 & 75 & 211 & 5.2 & 8.5 & 24.7 & 0.30 & 1.3 & 2.1 & 5.0 \\
\hline 10 & 160 & 359 & 3.1 & 4061 & 36 & 25317 & 6799 & 279 & 19030 & 1770 & 546 & 91 & 232 & 5.4 & 9.7 & 31.4 & 0.36 & 1.6 & 2.2 & 6.4 \\
\hline 20 & 72 & 184 & 3.1 & 4553 & 24 & 32631 & 5585 & 353 & 17474 & 1661 & 423 & 63 & 161 & 3.9 & 11.3 & 23.9 & $<0.12$ & 0.7 & 1.3 & 2.0 \\
\hline 20 & 160 & 359 & 3.3 & 4509 & 27 & 28273 & 5337 & 320 & 18789 & 1635 & 489 & 75 & 159 & 4.5 & 9.4 & 26.3 & 0.16 & 1.0 & 1.3 & 3.6 \\
\hline 40 & 72 & 184 & 3.3 & 3994 & 24 & 32186 & 5409 & 361 & 15569 & 1608 & 495 & 82 & 143 & 5.9 & 11.9 & 23.7 & 0.22 & 1.2 & 1.9 & 6.4 \\
\hline 40 & 160 & 359 & 3.5 & 4696 & 33 & 33842 & 4792 & 263 & 15818 & 1808 & 538 & 90 & 135 & 5.4 & 12.1 & 20.7 & 0.21 & 1.3 & 2.6 & 11.2 \\
\hline 80 & 72 & 184 & 3.0 & 3215 & 30 & 39289 & 5051 & 319 & 14338 & 1359 & 543 & 95 & 129 & 6.1 & 11.5 & 32.9 & 0.25 & 1.4 & $2 . \ddot{4}$ & 4.4 \\
\hline 80 & 160 & 359 & 3.1 & 4120 & 33 & 33045 & 5186 & 252 & 14123 & 1605 & 550 & 94 & 119 & 6.0 & 11.3 & 30.2 & 0.20 & 1.3 & 1.5 & 4.0 \\
\hline
\end{tabular}

\begin{tabular}{|c|c|c|c|c|c|c|c|c|c|c|c|c|c|c|c|c|c|c|c|c|}
\hline \multicolumn{3}{|c|}{ Treatments } & \multicolumn{18}{|c|}{ Chemical Analyses } \\
\hline Residue & $\mathrm{N}$ & $\mathrm{P}_{2} \mathrm{O}_{5}$ & $\mathrm{TKN}$ & $\mathrm{Cl}$ & $\mathrm{NO}_{3}$ & $\mathrm{Ca}$ & $\mathrm{Mg}$ & $\mathrm{Na}$ & $\mathrm{K}$ & $P$ & $\mathrm{Fe}$ & $\mathrm{Al}$ & $\mathrm{Mn}$ & $\mathrm{Cu}$ & $\mathrm{Zn}$ & $\mathrm{B}$ & $\mathrm{Cd}$ & $\mathrm{Cr}$ & $\mathrm{Ni}$ & $\mathrm{Pb}$ \\
\hline tons/ac & $\mathrm{lb} / \mathrm{ac}$ & $\mathrm{lb} / \mathrm{ac}$ & $\%$ & $\mathrm{ppm}$ & $\mathrm{ppm}$ & $\mathrm{ppm}$ & $\mathrm{ppm}$ & $\mathrm{ppm}$ & $\mathrm{ppm}$ & $\mathrm{ppm}$ & $\mathrm{ppm}$ & $\mathrm{ppm}$ & $\mathrm{ppm}$ & $\mathrm{ppm}$ & $\mathrm{ppm}$ & $\mathrm{ppm}$ & $\mathrm{ppm}$ & $\mathrm{ppm}$ & $\mathrm{ppm}$ & $\mathrm{ppm}$ \\
\hline 0 & 72 & 184 & 1.7 & 1151 & 4 & 4654 & 5247 & 64 & 19706 & 2240 & 488 & 52 & 446 & 8.1 & 7.7 & 21.2 & 0.29 & 1.2 & 3.6 & 4.9 \\
\hline 0 & 160 & 359 & 3.0 & 1171 & 560 & 4699 & 6389 & 79 & 22158 & 3574 & 627 & 60 & 451 & 11.2 & 7.0 & 24.8 & 0.38 & 1.4 & 2.5 & 5.6 \\
\hline 10 & 72 & 184 & 2.1 & 8716 & 1 & 4100 & 4029 & 125 & 27134 & 3053 & 264 & 54 & 267 & 7.0 & 9.3 & 25.8 & 0.55 & 1.8 & 3.7 & 9.8 \\
\hline 10 & 160 & 359 & 3.5 & 3314 & 152 & 5466 & 5240 & 93 & 26066 & 3982 & 498 & 61 & 205 & 11.0 & 9.0 & 24.1 & 0.48 & 1.7 & 3.2 & 8.0 \\
\hline 20 & 160 & 359 & 2.8 & 3215 & 95 & 5371 & 4386 & 117 & 28582 & 4565 & 598 & 62 & 234 & 8.4 & 9.8 & 24.7 & 0.39 & 1.4 & 3.4 & 7.8 \\
\hline
\end{tabular}

\footnotetext{
y ${ }^{1}$ Sample size $=1$
} 
Table 18.--Plant analysis of Medicago sativa (alfalfa) at Eveleth Mines, fall $1993^{1}$, grouped by de-inking residue rate.

\begin{tabular}{|c|c|c|c|c|c|}
\hline \multirow{3}{*}{$\begin{array}{c}\text { Chemical Element } \\
(\mathrm{mg} / \mathrm{kg})\end{array}$} & \multicolumn{5}{|c|}{ De-inking Residue Rate (dry ton/acre) } \\
\hline & 0 & 10 & 20 & 40 & 80 \\
\hline & $N=26$ & $\mathrm{~N}=17$ & $\mathrm{~N}=22$ & $N=23$ & $\mathrm{~N}=24$ \\
\hline Aluminum & $\begin{array}{l}94.3 \mathrm{a} \\
\pm 11.2 \\
\end{array}$ & $\begin{array}{l}77.1 \mathrm{a} \\
\pm 13.8 \\
\end{array}$ & $\begin{array}{l}77.4 \mathrm{a} \\
\pm 11.8 \\
\end{array}$ & $\begin{array}{l}76.2 \mathrm{a} \\
\pm 11.6 \\
\end{array}$ & $\begin{array}{l}75.5 \mathrm{a} \\
\pm 11.5 \\
\end{array}$ \\
\hline Boron & $\begin{array}{r}55.8 \mathrm{a} \\
\pm 8.9 \\
\end{array}$ & $\begin{array}{l}22.4 \mathrm{ac} \\
\pm 10.9 \\
\end{array}$ & $\begin{array}{l}17.2 \mathrm{bc} \\
\pm 9.4 \\
\end{array}$ & $\begin{array}{l}15.8 \mathrm{bc} \\
\pm 9.2 \\
\end{array}$ & $\begin{array}{l}22.3 \mathrm{ac} \\
\pm 9.2 \\
\end{array}$ \\
\hline Calcium & $\begin{array}{l}24,146 \mathrm{a} \\
\pm 3,941 \\
\end{array}$ & $\begin{array}{l}16,702 \mathrm{a} \\
\pm 4,826 \\
\end{array}$ & $\begin{array}{l}17,097 \mathrm{a} \\
\pm 4,133 \\
\end{array}$ & $\begin{array}{l}20,042 \mathrm{a} \\
\pm 4,065 \\
\end{array}$ & $\begin{array}{l}24,633 \mathrm{a} \\
\pm 4,045 \\
\end{array}$ \\
\hline Cadmium & $\begin{array}{l}0.98 \mathrm{a} \\
\pm 0.26 \\
\end{array}$ & $\begin{array}{l}0.18 \mathrm{a} \\
\pm 0.31 \\
\end{array}$ & $\begin{array}{l}0.32 \mathrm{a} \\
\pm 0.27 \\
\end{array}$ & $\begin{array}{l}0.32 \mathrm{a} \\
\pm 0.26 \\
\end{array}$ & $\begin{array}{l}0.49 \mathrm{a} \\
\pm 0.26 \\
\end{array}$ \\
\hline Chromium & $\begin{array}{l}2.12 \mathrm{a} \\
\pm 0.56 \\
\end{array}$ & $\begin{array}{l}0.82 \mathrm{a} \\
\pm 0.68 \\
\end{array}$ & $\begin{array}{l}0.82 \mathrm{a} \\
\pm 0.58 \\
\end{array}$ & $\begin{array}{l}0.83 \mathrm{a} \\
\pm 0.57 \\
\end{array}$ & $\begin{array}{l}1.40 \mathrm{a} \\
\pm 0.57 \\
\end{array}$ \\
\hline Copper & $\begin{array}{l}9.8 \mathrm{a} \\
\pm 1.5 \\
\end{array}$ & $\begin{array}{l}4.9 \mathrm{a} \\
\pm 1.8 \\
\end{array}$ & $\begin{array}{l}5.3 \mathrm{a} \\
\pm 1.5 \\
\end{array}$ & $\begin{array}{l}5.4 \mathrm{a} \\
\pm 1.5 \\
\end{array}$ & $\begin{array}{l}6.3 \mathrm{a} \\
\pm 1.5 \\
\end{array}$ \\
\hline Potassium & $\begin{array}{l}25,501 \mathrm{a} \\
\pm 3,687 \\
\end{array}$ & $\begin{array}{l}13,267 \mathrm{a} \\
\pm 4,516 \\
\end{array}$ & $\begin{array}{l}13,047 \mathrm{a} \\
\pm 3,867 \\
\end{array}$ & $\begin{array}{l}15,121 \mathrm{a} \\
\pm 3,804 \\
\end{array}$ & $\begin{array}{l}14,089 \mathrm{a} \\
\pm 3,785 \\
\end{array}$ \\
\hline Magnesium & $\begin{array}{l}7,282 \mathrm{a} \\
\pm 968 \\
\end{array}$ & $\begin{array}{l}3,513 \mathrm{ab} \\
\pm 1,186 \\
\end{array}$ & $\begin{array}{l}2,926 \mathrm{~b} \\
\pm 1,015 \\
\end{array}$ & $\begin{array}{l}2,663 b \\
\pm 999 \\
\end{array}$ & $\begin{array}{l}2,774 b \\
\pm 994 \\
\end{array}$ \\
\hline Manganese & $\begin{array}{r}306.0 \mathrm{a} \\
\pm 48.4 \\
\end{array}$ & $\begin{array}{c}166.4 \mathrm{ab} \\
\pm 59.2 \\
\end{array}$ & $\begin{array}{c}147.6 \mathrm{ab} \\
\pm 50.7 \\
\end{array}$ & $\begin{array}{r}131.4 \mathrm{ab} \\
\pm 49.9 \\
\end{array}$ & $\begin{array}{l}110.0 \mathrm{bc} \\
\pm 49.6 \\
\end{array}$ \\
\hline Sodium & $\begin{array}{r}173.9 \mathrm{a} \\
\pm 43.6 \\
\end{array}$ & $\begin{array}{r}153.6 \mathrm{a} \\
\pm 53.3 \\
\end{array}$ & $\begin{array}{r}117.4 \mathrm{a} \\
\pm 45.7 \\
\end{array}$ & $\begin{array}{l}97.3 \mathrm{a} \\
\pm 44.9 \\
\end{array}$ & $\begin{array}{r}122.8 \mathrm{a} \\
\pm 44.7 \\
\end{array}$ \\
\hline Nickel & $\begin{array}{l}10.1 \mathrm{a} \\
\pm 2.5 \\
\end{array}$ & $\begin{array}{l}2.0 \mathrm{a} \\
\pm 3.1 \\
\end{array}$ & $\begin{array}{l}2.1 \mathrm{a} \\
\pm 2.7 \\
\end{array}$ & $\begin{array}{l}2.0 \mathrm{a} \\
\pm 2.6 \\
\end{array}$ & $\begin{array}{l}3.0 \mathrm{a} \\
\pm 2.6 \\
\end{array}$ \\
\hline Phosphorus & $\begin{array}{c}2,335 a \\
\pm 327 \\
\end{array}$ & $\begin{array}{l}1,222 a \\
\pm 401 \\
\end{array}$ & $\begin{array}{r}1,284 \mathrm{a} \\
\pm 343 \\
\end{array}$ & $\begin{array}{r}1,591 \mathrm{a} \\
\pm 337 \\
\end{array}$ & $\begin{array}{r}1,430 \mathrm{a} \\
\pm 336 \\
\end{array}$ \\
\hline Lead & $\begin{array}{l}13.5 \mathrm{a} \\
\pm 3.4 \\
\end{array}$ & $\begin{array}{l}3.3 \mathrm{a} \\
\pm 4.2 \\
\end{array}$ & $\begin{array}{l}3.0 \mathrm{a} \\
\pm 3.6 \\
\end{array}$ & $\begin{array}{l}3.3 \mathrm{a} \\
\pm 3.5 \\
\end{array}$ & $\begin{array}{l}7.6 \mathrm{a} \\
\pm 3.5 \\
\end{array}$ \\
\hline Zinc & $\begin{array}{l}11.5 \mathrm{a} \\
\pm 1.8 \\
\end{array}$ & $\begin{array}{l}10.7 \mathrm{a} \\
\pm 2.3 \\
\end{array}$ & $\begin{array}{l}11.9 \mathrm{a} \\
\pm 1.9 \\
\end{array}$ & $\begin{array}{l}15.6 \mathrm{a} \\
\pm 1.9 \\
\end{array}$ & $\begin{array}{l}16.6 \mathrm{a} \\
\pm 1.9 \\
\end{array}$ \\
\hline
\end{tabular}

${ }^{1}$ Mean values \pm standard error, which includes all fertilizer levels for each residue rate, except the control (no fertilizer). No alfalfa plant samples were collected on the fertilizer control plots. $\mathrm{N}=$ the number of plant samples for each de-inking residue application rate. Means within the same row followed by the same letter are not significantly different at the 0.05 level. 
Table 19.--Plant analysis of Fagopyrum esculentum (buckwheat) at Eveleth Mines, fall 1993.

\begin{tabular}{|c|c|c|c|c|c|c|c|c|c|c|c|c|c|c|c|c|c|}
\hline \multicolumn{3}{|c|}{ Treatments } & \multirow{3}{*}{$\begin{array}{c}\text { Number } \\
\text { of } \\
\text { Samples }\end{array}$} & \multicolumn{14}{|c|}{ Chemical Analyses } \\
\hline Residue & $\mathrm{N}$ & $\mathrm{P}_{2} \mathrm{O}_{5}$ & & $\mathrm{Al}$ & B & $\mathrm{Ca}$ & $\mathrm{Cd}$ & $\mathrm{Cr}_{\mathrm{r}}$ & $\mathrm{Cu}$ & $\mathrm{K}$ & $\mathrm{Mg}$ & $\mathrm{Mn}$ & $\mathrm{Na}$ & $\mathrm{Ni}$ & $\mathrm{P}$ & $\mathrm{Pb}$ & $\mathrm{Zn}$ \\
\hline tons/ac & $\mathrm{lb} / \mathrm{ac}$ & $\mathrm{lb} / \mathrm{ac}$ & & $\mathrm{ppm}$ & $\mathrm{ppm}$ & $\mathrm{ppm}$ & $\mathrm{ppm}$ & $\mathrm{ppm}$ & $\mathrm{ppm}$ & $\mathrm{ppm}$ & $\mathrm{ppm}$ & $\mathrm{ppm}$ & $\mathrm{ppm}$ & $\mathrm{ppm}$ & $\mathrm{ppm}$ & $\mathrm{ppm}$ & $\mathrm{ppm}$ \\
\hline 0 & 0 & 0 & 13 & 112 & 28 & 15081 & 1.2 & 4.1 & 6.0 & 15965 & 9700 & 437 & 228 & 6.1 & 1338 & 11 & 25 \\
\hline 0 & 36 & 36 & 5 & 98 & 27 & 9879 & 1.2 & 4.9 & 7.0 & 16851 & 5815 & 284 & 274 & 6.7 & 4677 & 18 & 34 \\
\hline 0 & 80 & 180 & 11 & 56 & 18 & 6228 & 0.79 & 1.2 & 3.7 & 14290 & 5020 & 136 & 88 & 4.7 & 5295 & 11 & 22 \\
\hline 0 & 72 & 184 & 3 & 86 & 22 & 9177 & 0.81 & 3.9 & 3.6 & 19986 & 7925 & 193 & 187 & 4.8 & 7065 & 14 & 27 \\
\hline 0 & 160 & 359 & 11 & 48 & 20 & 5864 & 0.48 & 1.3 & 3.7 & 15865 & 5881 & 148 & 80 & 3.4 & 5973 & 8.1 & 22 \\
\hline 10 & 0 & 0 & 1 & 48 & 27 & 17783 & 61 & 2.1 & 5.0 & 31957 & 7916 & 134 & 27 & 3.6 & 3439 & 13 & 50 \\
\hline 10 & 36 & 36 & 1 & 38 & 29 & 15554 & 0.24 & 0.87 & 7.3 & 24710 & 7053 & 73 & 39 & 3.8 & 5234 & 13 & 40 \\
\hline 10 & 80 & 180 & 1 & 66 & 43 & 16545 & 0.57 & 5.2 & 17 & 18578 & 10312 & 107 & 762 & 2.4 & 7289 & 10 & 51 \\
\hline 20 & 36 & 36 & 2 & 183 & 38 & 18187 & 1.9 & 4.6 & 18 & 31605 & 8654 & 110 & 541 & 9.4 & 11940 & 27 & 58 \\
\hline 40 & 0 & 0 & 1 & 215 & 28 & 18161 & 7.2 & 17 & 31 & 16376 & 5339 & 53 & 216 & 26 & 3854 & 101 & 53 \\
\hline 80 & 72 & 184 & 2 & 44 & 50 & 14187 & 0.36 & 1.3 & 7.2 & 20734 & 5691 & 106 & 37 & 11 & 5215 & 31 & 38 \\
\hline 80 & 160 & 359 & 1 & 65 & 32 & 13127 & 0.49 & 2.2 & 6.5 & 28262 & 6616 & 137 & 28 & 2.2 & 6131 & 6.8 & 31 \\
\hline
\end{tabular}


Table 20.--Plant analysis of Festuca rubra (red fescue) at Eveleth Mines, fall 1993.

\begin{tabular}{|c|c|c|c|c|c|c|c|c|c|c|c|c|c|c|c|c|c|}
\hline \multicolumn{3}{|c|}{ Treatments } & \multirow{3}{*}{$\begin{array}{l}\text { Number } \\
\text { of } \\
\text { Samples }\end{array}$} & \multicolumn{14}{|c|}{ Chemical Analyses } \\
\hline Residue & $\mathrm{N}$ & $\mathrm{P}_{2} \mathrm{O}_{5}$ & & $\mathrm{Al}$ & $\mathrm{B}$ & $\mathrm{Ca}$ & $\mathrm{Cd}$ & $\mathrm{Cr}$ & $\mathrm{Cu}$ & $\mathrm{K}$ & $\mathrm{Mg}$ & $\mathrm{Mn}$ & $\mathrm{Na}$ & $\mathrm{Ni}$ & $\mathrm{P}$ & $\mathrm{Pb}$ & $\mathrm{Zn}$ \\
\hline tons/ac & $\mathrm{lb} / \mathrm{ac}$ & $\mathrm{lb} / \mathrm{ac}$ & & $\mathrm{ppm}$ & ppm & $\mathrm{ppm}$ & $\mathrm{ppm}$ & $\mathrm{ppm}$ & $\mathrm{ppm}$ & $\mathrm{ppm}$ & $\mathrm{ppm}$ & $\mathrm{ppm}$ & $\mathrm{ppm}$ & $\mathrm{ppm}$ & $\mathrm{ppm}$ & $\mathrm{ppm}$ & $\mathrm{ppm}$ \\
\hline 0 & 0 & 0 & 22 & 81 & 13 & 4660 & 1.4 & 3.1 & 4.7 & 5334 & 2631 & 645 & 255 & 7.5 & 361 & 8.6 & 16.9 \\
\hline 0 & 36 & 92 & 11 & 37 & 12 & 5276 & 0.73 & 0.68 & 1.9 & 9646 & 3724 & 659 & 101 & 3.4 & 1217 & 3.5 & 9.8 \\
\hline 0 & 80 & 180 & 11 & 46 & 8.2 & 4361 & 1.4 & 0.58 & 2.2 & 11880 & 3635 & 532 & 62 & 4.6 & 1664 & 7.5 & 8.3 \\
\hline 0 & 72 & 184 & 12 & 30 & 7.6 & 4404 & 1.2 & 0.89 & 1.5 & 8674 & 3346 & 588 & 54 & 3.2 & 1258 & 5.1 & 6.9 \\
\hline 0 & 160 & 359 & 10 & 189 & 7.1 & 3822 & 0.25 & 1.3 & 10 & 13322 & 3378 & 529 & 49 & 5.1 & 2012 & 208 & 11 \\
\hline 10 & 36 & 92 & 1 & 84 & 25 & 6397 & 0.33 & 1.1 & 5.9 & 40463 & 2886 & 191 & 64 & 4.9 & 3453 & 5.1 & 20 \\
\hline 10 & 80 & 180 & 3 & 31 & 17 & 5260 & 0.32 & 0.83 & 3.9 & 24555 & 3334 & 286 & 27 & 3.1 & 2873 & 3.8 & 15 \\
\hline 10 & 72 & 184 & 1 & 438 & 14 & 7223 & 2.1 & 4.2 & 97 & 31027 & 2395 & 229 & 1479 & 5.5 & 2497 & 18 & 67 \\
\hline 10 & 160 & 359 & 2 & 58 & 9.2 & 6191 & 0.22 & 0.76 & 4.6 & 24856 & 2896 & 244 & 134 & 3.4 & 3454 & 2.7 & 21 \\
\hline 20 & 80 & 180 & 1 & 390 & 31 & 6075 & 1.8 & 4.2 & 14 & 40088 & 2920 & 181 & 1012 & 23 & 5620 & 25 & $4 \dot{9}$ \\
\hline 20 & 160 & 359 & 3 & 65 & 13 & 6716 & 0.60 & 0.85 & 4.7 & 29237 & 2781 & 200 & 159 & 6.0 & 3331 & 6.1 & 18 \\
\hline 40 & 0 & 0 & 1 & 124 & 5.5 & 4456 & 0.36 & 0.83 & 3.6 & 5331 & 2699 & 839 & 544 & 5.8 & 326 & 5.0 & 23 \\
\hline 80 & 72 & 184 & 2 & 39 & 17 & 4704 & 0.17 & 0.70 & 4.6 & 31036 & 2597 & 231 & 57 & 3.5 & 3134 & 6.4 & 18 \\
\hline 80 & 160 & 359 & 1 & 64 & 31 & 6522 & 0.21 & 0.89 & 4.3 & 25823 & 3554 & 395 & 26 & 4.0 & 4888 & 2.7 & 19 \\
\hline
\end{tabular}


Table 21.--Plant analysis of Bromus inermis (smooth bromegrass) at Eveleth Mines, fall 1993.

\begin{tabular}{|c|c|c|c|c|c|c|c|c|c|c|c|c|c|c|c|c|c|}
\hline \multicolumn{3}{|c|}{ Treatments } & \multirow{3}{*}{$\begin{array}{l}\text { Number } \\
\text { of } \\
\text { Samples }\end{array}$} & \multicolumn{14}{|c|}{ Chemical Analyses } \\
\hline Residue & $\mathrm{N}$ & $\mathrm{P}_{2} \mathrm{O}_{5}$ & & $\mathrm{Al}$ & B & $\mathrm{Ca}$ & $\mathrm{Cd}$ & $\mathrm{Cr}$ & $\mathrm{Cu}$ & $\mathrm{K}$ & $\mathrm{Mg}$ & $\mathrm{Mn}$ & $\mathrm{Na}$ & $\mathrm{Ni}$ & $\mathrm{P}$ & $\mathrm{Pb}$ & $\mathrm{Zn}$ \\
\hline tons/ac & $\mathrm{lb} / \mathrm{ac}$ & $\mathrm{lb} / \mathrm{ac}$ & & $\mathrm{ppm}$ & $\mathrm{ppm}$ & $\mathrm{ppm}$ & $\mathrm{ppm}$ & $\mathrm{ppm}$ & $\mathrm{ppm}$ & $\mathrm{ppm}$ & $\mathrm{ppm}$ & $\mathrm{ppm}$ & $\mathrm{ppm}$ & $\mathrm{ppm}$ & $\mathrm{ppm}$ & $\mathrm{ppm}$ & $\mathrm{ppm}$ \\
\hline 0 & 0 & 0 & 11 & 192 & 21 & 4647 & 1.5 & 12 & 9.6 & 7172 & 2868 & 624 & 345 & 11 & 461 & 24 & 29 \\
\hline 0 & 36 & 92 & 9 & 68 & 15 & 5117 & 0.50 & 1.7 & 4.9 & 10113 & 3595 & 481 & 227 & 4.3 & 924 & 11 & 13 \\
\hline 0 & 80 & 180 & 14 & 58 & 11 & 4312 & 0.60 & 1.6 & 3.7 & 7848 & 2965 & 411 & 82 & 2.5 & 1062 & 5.8 & 8.5 \\
\hline 0 & 72 & 184 & 10 & 65 & 12 & 5044 & 0.41 & 1.9 & 2.8 & 8148 & 2952 & 509 & 139 & 3.0 & 1025 & 6.0 & 8.9 \\
\hline 0 & 160 & 359 & 10 & 66 & 11 & 4191 & 0.41 & 1.1 & 2.9 & 8154 & 2902 & 473 & 143 & 1.9 & 1454 & 3.8 & 7.0 \\
\hline 10 & 80 & 180 & 1 & 56 & 15 & 6233 & 0.78 & 1.0 & 7.2 & 19954 & 5535 & 348 & 143 & 2.5 & 2827 & 4.2 & 13 \\
\hline 10 & 160 & 359 & 2 & 50 & 16 & 25359 & 1.8 & 0.68 & 3.6 & 18553 & 3427 & 246 & 143 & 2.2 & 2545 & 7.2 & 13 \\
\hline 20 & 80 & 180 & 1 & 35 & 11 & 6204 & 0.57 & 0.72 & 5.7 & 24356 & 3319 & 321 & 23 & 2.0 & 2809 & 3.1 & 19 \\
\hline 20 & 72 & 184 & 1 & 46 & 14 & 6934 & 0.34 & 0.85 & 6.9 & 36425 & 2685 & 153 & 284 & 4.7 & 4863 & 19 & 35 \\
\hline 20 & 160 & 359 & 2 & 46 & 9.2 & 4881 & 0.14 & 0.65 & 3.9 & 25771 & 2771 & 210 & 40 & 1.3 & 2898 & 2.9 & 13 \\
\hline 80 & 160 & 359 & 1 & 162 & 35 & 5322 & 0.42 & 1.8 & 7.1 & 12746 & 2919 & 346 & 34 & 4.2 & 2405 & 8.2 & 13 \\
\hline
\end{tabular}


Table 22.--Plant analysis of Andropogon gerardii and Schizachyrium scoparium (big and little bluestem) at Eveleth Mines, fall $1993^{1}$, grouped by de-inking residue rate.

\begin{tabular}{|c|c|c|c|c|}
\hline \multirow{3}{*}{$\begin{array}{l}\text { Chemical } \\
\text { Element } \\
(\mathrm{mg} / \mathrm{kg})\end{array}$} & \multicolumn{4}{|c|}{ De-inking Residue Rate (dry ton/acre) } \\
\hline & 0 & 10 & 20 & 40 \\
\hline & $\mathrm{N}=47$ & $N=27$ & $N=20$ & $N=16$ \\
\hline Aluminum & $\begin{array}{r}138.2 \mathrm{a} \\
\pm 20.4 \\
\end{array}$ & $\begin{array}{r}170.3 \mathrm{a} \\
\pm 26.4 \\
\end{array}$ & $\begin{array}{r}187.6 \mathrm{a} \\
\pm 33.7 \\
\end{array}$ & $\begin{array}{r}241.3 \mathrm{a} \\
\pm 35.1 \\
\end{array}$ \\
\hline Boron & $\begin{array}{l}27.4 \mathrm{a} \\
\pm 4.3 \\
\end{array}$ & $\begin{array}{l}20.5 \mathrm{a} \\
\pm 5.6 \\
\end{array}$ & $\begin{array}{l}13.5 \mathrm{a} \\
\pm 7.1 \\
\end{array}$ & $\begin{array}{l}14.9 \mathrm{a} \\
\pm 7.4 \\
\end{array}$ \\
\hline Calcium & $\begin{array}{l}4,215 a \\
\pm 415 \\
\end{array}$ & $\begin{array}{l}5,087 \mathrm{ab} \\
\pm 536\end{array}$ & $\begin{array}{c}6,367 \mathrm{bc} \\
\pm 685 \\
\end{array}$ & $\begin{array}{r}8,012 \mathrm{c} \\
\pm 714 \\
\end{array}$ \\
\hline Cadmium & $\begin{array}{l}2.03 \mathrm{a} \\
\pm 0.64 \\
\end{array}$ & $\begin{array}{l}1.63 \mathrm{a} \\
\pm 0.83 \\
\end{array}$ & $\begin{array}{l}2.80 \mathrm{a} \\
\pm 1.05 \\
\end{array}$ & $\begin{array}{l}1.05 \mathrm{a} \\
\pm 1.10 \\
\end{array}$ \\
\hline Chromium & $\begin{array}{l}6.8 \mathrm{a} \\
\pm 1.0 \\
\end{array}$ & $\begin{array}{l}6.7 \mathrm{a} \\
\pm 1.3 \\
\end{array}$ & $\begin{array}{l}4.9 \mathrm{a} \\
\pm 1.7 \\
\end{array}$ & $\begin{array}{l}3.8 \mathrm{a} \\
\pm 1.8 \\
\end{array}$ \\
\hline Copper & $\begin{array}{l}5.56 a \\
\pm 0.70 \\
\end{array}$ & $\begin{array}{l}6.66 \mathrm{a} \\
\pm 0.90 \\
\end{array}$ & $\begin{array}{l}6.53 \mathrm{a} \\
\pm 1.16 \\
\end{array}$ & $\begin{array}{l}5.53 \mathrm{a} \\
\pm 1.20 \\
\end{array}$ \\
\hline Potassium & $\begin{array}{l}5,783 a \\
\pm 292 \\
\end{array}$ & $\begin{array}{l}6,455 a \\
\pm 378 \\
\end{array}$ & $\begin{array}{l}6,753 a \\
\pm 483 \\
\end{array}$ & $\begin{array}{l}6,749 a \\
\pm 503 \\
\end{array}$ \\
\hline Magnesium & $\begin{array}{l}2,915 a \\
\pm 122 \\
\end{array}$ & $\begin{array}{l}3,050 \mathrm{a} \\
\pm 158 \\
\end{array}$ & $\begin{array}{l}2,788 \mathrm{ab} \\
\pm 202 \\
\end{array}$ & $\begin{array}{l}2,251 \mathrm{~b} \\
\pm 211 \\
\end{array}$ \\
\hline Manganese & $\begin{array}{l}329.7 \mathrm{a} \\
\pm 17.7 \\
\end{array}$ & $\begin{array}{r}267.2 \mathrm{ac} \\
\pm 22.9 \\
\end{array}$ & $\begin{array}{l}229.0 \mathrm{bc} \\
\pm 29.3 \\
\end{array}$ & $\begin{array}{l}173.3 b c \\
\pm 30.5 \\
\end{array}$ \\
\hline Sodium & $\begin{array}{r}348.3 \mathrm{a} \\
\pm \quad 35.9 \\
\end{array}$ & $\begin{array}{r}359.8 \mathrm{a} \\
\pm 46.4 \\
\end{array}$ & $\begin{array}{r}234.5 \mathrm{a} \\
\pm 59.3 \\
\end{array}$ & $\begin{array}{r}315.9 \mathrm{a} \\
\pm 61.8 \\
\end{array}$ \\
\hline Nickel & $\begin{array}{l}7.3 \mathrm{a} \\
\pm 1.6 \\
\end{array}$ & $\begin{array}{r}10.3 \mathrm{a} \\
\pm 2.1 \\
\end{array}$ & $\begin{array}{l}7.6 \mathrm{a} \\
\pm 2.6 \\
\end{array}$ & $\begin{array}{l}5.5 \mathrm{a} \\
\pm 2.7 \\
\end{array}$ \\
\hline Phosphorus & $\begin{array}{l}879.8 \mathrm{a} \\
\pm 62.8 \\
\end{array}$ & $\begin{array}{c}1,095.8 \mathrm{a} \\
\pm 81.1 \\
\end{array}$ & $\begin{array}{l}1,070.3 \mathrm{a} \\
\pm 103.6 \\
\end{array}$ & $\begin{array}{l}1,075.5 \mathrm{a} \\
\pm 108.0 \\
\end{array}$ \\
\hline Lead & $\begin{array}{r}17.2 \mathrm{a} \\
\pm 2.7 \\
\end{array}$ & $\begin{array}{r}20.3 \mathrm{a} \\
\pm 3.5 \\
\end{array}$ & $\begin{array}{r}19.4 \mathrm{a} \\
\pm 4.5 \\
\end{array}$ & $\begin{array}{r}18.1 \mathrm{a} \\
\pm 4.7 \\
\end{array}$ \\
\hline Zinc & $\begin{array}{r}13.9 \mathrm{a} \\
\pm 1.3 \\
\end{array}$ & $\begin{array}{r}19.6 b c \\
\pm 1.7 \\
\end{array}$ & $\begin{array}{r}20.7 b c \\
\pm 2.2 \\
\end{array}$ & $\begin{array}{c}18.8 \mathrm{ac} \\
\pm 2.3 \\
\end{array}$ \\
\hline
\end{tabular}

${ }^{1}$ Mean values \pm standard error, which includes all fertilizer levels for each residue rate. Since an inadequate number of bluestem plant samples (6) were collected from plots amended with 80 ton/acre, this residue rate was not included in the statistical analysis. $N=$ the number of plant samples for each de-inking residue application rate. Means within the same row followed by the same letter are not significantly different at the 0.05 level. 
Table 23.--Plant analysis of Andropogon gerardii and Schizachyrium scoparium (big and little bluestem) at Eveleth Mines, fall $1993^{1}$, grouped by fertilizer rate.

\begin{tabular}{|c|c|c|c|c|c|}
\hline \multirow{3}{*}{$\begin{array}{l}\text { Chemical } \\
\text { Element } \\
(\mathrm{mg} / \mathrm{kg})\end{array}$} & \multicolumn{5}{|c|}{ Fertilizer Rate (lb/acre) } \\
\hline & No Fertilizer & $\begin{array}{c}\mathrm{N}=36 \\
\mathrm{P}_{2} \mathrm{O}_{5}=92\end{array}$ & $\begin{array}{c}\mathrm{N}=80 \\
\mathrm{P}_{2} \mathrm{O}_{5}=180\end{array}$ & $\begin{array}{c}\mathrm{N}=72 \\
\mathrm{P}_{2} \mathrm{O}_{5}=184\end{array}$ & $\begin{array}{c}\mathrm{N}=160 \\
\mathrm{P}_{2} \mathrm{O}_{5}=359\end{array}$ \\
\hline & $N=32$ & $N=19$ & $N=21$ & $\mathrm{~N}=17$ & $N=21$ \\
\hline Potassium & $\begin{array}{l}3,997 a \\
\pm 376 \\
\end{array}$ & $\begin{array}{l}6,003 b \\
\pm 545 \\
\end{array}$ & $\begin{array}{l}6,788 b \\
\pm 456 \\
\end{array}$ & $\begin{array}{c}7,129 b \\
\pm 523 \\
\end{array}$ & $\begin{array}{l}8,258 \mathrm{bc} \\
\pm 442 \\
\end{array}$ \\
\hline Magnesium & $\begin{array}{l}2,450 \mathrm{a} \\
\pm 158 \\
\end{array}$ & $\begin{array}{l}2,371 a \\
\pm 228 \\
\end{array}$ & $\begin{array}{l}2,827 \mathrm{ab} \\
\pm 191 \\
\end{array}$ & $\begin{array}{l}2,689 \mathrm{ab} \\
\pm 219 \\
\end{array}$ & $\begin{array}{l}3,419 b \\
\pm 185 \\
\end{array}$ \\
\hline Phosphorus & $\begin{array}{l}470.1 \mathrm{a} \\
\pm 80.8\end{array}$ & $\begin{array}{l}769.5 \mathrm{ac} \\
\pm 117.0\end{array}$ & $\begin{array}{c}1,098.7 \mathrm{bc} \\
\pm 97.9\end{array}$ & $\begin{array}{c}1,214.7 b c \\
\pm 112.2\end{array}$ & $\begin{array}{c}1,598.8 \mathrm{bd} \\
\pm 95.0\end{array}$ \\
\hline
\end{tabular}

${ }^{1}$ Mean values \pm standard error, which includes all de-inking residue rates except 80 dry ton/acre. An inadequate number of bluestem plant samples (6) were collected from plots amended with 80 ton/acre to be included with this statistical analysis.

$\mathrm{N}=$ the number of plant samples for each fertilizer application rate. Means within the same row followed by the same letter are not significantly different at the 0.05 level. 
Table 24.--Plant analysis of Elymus canadensis (Canada wild rye) at Eveleth Mines, fall 1993.

\begin{tabular}{|c|c|c|c|c|c|c|c|c|c|c|c|c|c|c|c|c|c|}
\hline \multicolumn{3}{|c|}{ Treatments } & \multirow{3}{*}{$\begin{array}{c}\text { Number } \\
\text { of } \\
\text { Samples }\end{array}$} & \multicolumn{14}{|c|}{ Chemical Analyses } \\
\hline Residue & $\mathrm{N}$ & $\mathrm{P}_{2} \mathrm{O}_{5}$ & & $\mathrm{Al}$ & $\mathrm{B}$ & $\mathrm{Ca}$ & $\mathrm{Cd}$ & $\mathrm{Cr}$ & $\mathrm{Cu}$ & K & $\mathrm{Mg}$ & $\mathrm{Mn}$ & $\mathrm{Na}$ & $\mathrm{Ni}$ & $\mathrm{P}$ & $\mathrm{Pb}$ & $\mathrm{Zn}$ \\
\hline tons/ac & $\mathrm{lb} / \mathrm{ac}$ & $\mathrm{lb} / \mathrm{ac}$ & & ppm & ppm & $\mathrm{ppm}$ & ppm & ppm & $\mathrm{ppm}$ & ppm & ppm & ppm & $\mathrm{ppm}$ & ppm & ppm & ppm & ppm \\
\hline 0 & 0 & 0 & 10 & 133 & 21 & 6097 & 0.54 & 4.6 & 5.5 & 8145 & 2840 & 530 & 174 & 31 & 951 & 13 & 28.6 \\
\hline 0 & 36 & 92 & 11 & 54 & 9.4 & 4452 & 0.92 & 0.89 & 4.2 & 5089 & 2468 & 268 & 68 & 8.3 & 1166 & 22 & 5.1 \\
\hline 0 & 80 & 180 & 6 & 83 & 9.6 & 3302 & 0.71 & 1.8 & 4.8 & 8331 & 2325 & 212 & 142 & 3.4 & 1482 & 9.3 & 7.4 \\
\hline 0 & 72 & 184 & 12 & 53 & 20 & 3999 & 0.50 & 6.7 & 3.6 & 4659 & 2262 & 218 & 131 & 5.7 & 1115 & 13 & 6.1 \\
\hline 0 & 160 & 359 & 9 & 67 & 12 & 3272 & 0.75 & 2.2 & 4.5 & 7680 & 2075 & 238 & 100 & 5.2 & 1972 & 9.8 & 21 \\
\hline 10 & 0 & 0 & 1 & 121 & 13 & 5428 & 1.9 & 1.1 & 5.5 & 10940 & 2978 & 132 & 132 & 4.4 & 1616 & 6.3 & 24 \\
\hline 10 & 36 & 92 & 3 & 93 & 6.0 & 4700 & 0.51 & 4.2 & 5.8 & 13755 & 2702 & 204 & 379 & 2.2 & 2379 & 7.1 & 13 \\
\hline 10 & 80 & 180 & 4 & 38 & 5.3 & 4071 & 0.14 & 0.58 & 1.9 & 7815 & 2365 & 129 & 10 & 1.3 & 1793 & 4.3 & 11 \\
\hline 10 & 72 & 184 & 6 & 79 & 7.4 & 3963 & 1.1 & 2.5 & 6.1 & 10398 & 2581 & 142 & 159 & 4.5 & 2183 & 11 & 27 \\
\hline 10 & 160 & 359 & 1 & 31 & 7.3 & 3465 & 0.30 & 0.52 & 1.6 & 4850 & 1981 & 111 & 7.3 & 1.2 & 1234 & 8.4 & 5.2 \\
\hline 20 & 36 & 92 & 1 & 34 & 2.7 & 5358 & 0.39 & 0.54 & 1.7 & 6500 & 1928 & 204 & 6.0 & 0.86 & 1469 & 2.9 & 16 \\
\hline 20 & 80 & 180 & 3 & 46 & 6.3 & 5068 & 2.7 & 0.44 & 3.5 & 14528 & 1987 & 137 & 43 & 2.0 & 2377 & 6.0 & 12 \\
\hline 20 & 72 & 184 & 1 & 22 & 4.0 & 5198 & 0.56 & 0.57 & 3.4 & 21026 & 2663 & 40 & 8.0 & 0.89 & 4069 & 4.4 & 12 \\
\hline 20 & 160 & 359 & 3 & 34 & 4.0 & 3575 & 0.41 & 0.99 & 2.2 & 9208 & 1782 & 88 & 44 & 1.0 & 2133 & 2.8 & 12 \\
\hline 40 & 80 & 180 & 2 & 81 & 4.1 & 5763 & 2.2 & 1.7 & 4.4 & 15680 & 1632 & 61 & 260 & 3.3 & 3042 & 13 & 18 \\
\hline 40 & 72 & 184 & 2 & 400 & 8.9 & 8043 & 0.84 & 2.9 & 5.7 & 11211 & 2127 & 143 & 131 & 11 & 2467 & 17 & 16 \\
\hline 40 & 160 & 359 & 1 & 121 & 17 & 5170 & 0.39 & 0.71 & 4.2 & 21381 & 1857 & 48 & 41 & 2.3 & 3715 & 4.1 & 17 \\
\hline 80 & 160 & 359 & 1 & 221 & 9.1 & 5675 & 0.66 & 1.5 & 6.5 & 15099 & 1287 & 68 & 460 & 3.7 & 3785 & 9.2 & 31 \\
\hline
\end{tabular}


Table 25.--Plant analysis of Bromus kalmii (kalm's brome) at Eveleth Mines, fall 1993.

\begin{tabular}{|c|c|c|c|c|c|c|c|c|c|c|c|c|c|c|c|c|c|}
\hline \multicolumn{3}{|c|}{ Treatments } & \multirow{3}{*}{$\begin{array}{c}\text { Number } \\
\text { of } \\
\text { Samples }\end{array}$} & \multicolumn{14}{|c|}{ Chemical Analyses } \\
\hline Residue & $N$ & $\mathrm{P}_{2} \mathrm{O}_{5}$ & & $\mathrm{Al}$ & B & $\mathrm{Ca}$ & $\mathrm{Cd}$ & $\mathrm{Cr}$ & $\mathrm{Cu}$ & $\mathrm{K}$ & $\mathrm{Mg}$ & Mn & $\mathrm{Na}$ & $\mathrm{Ni}$ & $\mathrm{P}$ & $\mathrm{Pb}$ & $\mathrm{Zn}$ \\
\hline tons/ac & $\mathrm{Ib} / \mathrm{ac}$ & $\mathrm{lb} / \mathrm{ac}$ & & $\mathrm{ppm}$ & $\mathrm{ppm}$ & $\mathrm{ppm}$ & ppm & ppm & ppm & ppm & $\mathrm{ppm}$ & $\mathrm{ppm}$ & $\mathrm{ppm}$ & $\mathrm{ppm}$ & ppm & $\mathrm{ppm}$ & ppm \\
\hline 0 & 0 & 0 & 5 & 122 & 13 & 5741 & 1.4 & 8.8 & 6.2 & 4211 & 2531 & 300 & 213 & 5.3 & 396 & 19 & 21 \\
\hline 0 & 36 & 92 & 5 & 162 & 13 & 7101 & 1.4 & 17 & 6.9 & 7454 & 3223 & 414 & 355 & 12 & 827 & 17 & 14 \\
\hline 0 & 80 & 180 & 5 & 157 & 22 & 7498 & 1.4 & 5.2 & 7.1 & 8791 & 3795 & 430 & 244 & 6.1 & 1100 & 16 & 27 \\
\hline 0 & 72 & 184 & 5 & 114 & 33 & 6383 & 9.4 & 10 & 9.3 & 6994 & 3823 & 332 & 376 & 25 & 928 & 85 & 13 \\
\hline 0 & 160 & 359 & 1 & 250 & 13 & 10743 & 3.0 & 8.5 & 13 & 3670 & 2599 & 443 & 263 & 13 & 1250 & 42 & 22 \\
\hline 10 & 36 & 92 & 4 & 169 & 8.2 & 5405 & 1.7 & 2.8 & 7.0 & 14495 & 3004 & 174 & 108 & 6.0 & 1180 & 20 & 11 \\
\hline 10 & 80 & 180 & 4 & 70 & 7.8 & 5226 & 0.48 & 0.84 & 3.7 & 15506 & 3648 & 87 & 91 & 2.5 & 1484 & 8.7 & 9.7 \\
\hline 10 & 72 & 184 & 1 & 123 & 9.8 & 6254 & 1.6 & 14 & 27 & 14516 & 4219 & 208 & 1992 & 11 & 1399 & 23 & 41 \\
\hline 10 & 160 & 359 & 5 & 75 & 23 & 6015 & 0.78 & 1.1 & 4.0 & 15966 & 3999 & 134 & 56 & 2.9 & 1547 & 10 & 9.8 \\
\hline 20 & 0 & 0 & 3 & 267 & 12 & 5590 & 2.4 & 11 & 11 & 5207 & 2238 & 202 & 159 & 9.0 & 368 & 33 & 18 \\
\hline 20 & 36 & 92 & 2 & 48 & 7.9 & 4816 & 2.7 & 0.83 & 3.1 & 16187 & 3914 & 90 & 67 & 2.8 & 1681 & 5.5 & 15 \\
\hline 20 & 80 & 180 & 4 & 143 & 8.6 & 5322 & 6.4 & 1.2 & 6.8 & 21165 & 2691 & 79 & 358 & 3.4 & 1935 & 5.7 & 20 \\
\hline 20 & 72 & 184 & 2 & 98 & 11 & 8338 & 1.2 & 5.7 & 6.3 & 20127 & 3212 & 205 & 164 & 4.6 & 2936 & 17 & 21 \\
\hline 20 & 160 & 359 & 4 & 85 & 30 & 5738 & 1.6 & 4.0 & 8.5 & 18404 & 3097 & 129 & 269 & 7.4 & 1766 & 27 & 14 \\
\hline 40 & 80 & 180 & 2 & 117 & 9.2 & 10084 & 1.5 & 3.9 & 9.6 & 27731 & 2870 & 246 & 538 & 6.4 & 3552 & 21 & 27 \\
\hline 40 & 72 & 184 & 2 & 212 & 9.8 & 7740 & 1.5 & 4.6 & 6.7 & 15330 & 2654 & 132 & 336 & 5.7 & 1640 & 21 & 20 \\
\hline 40 & 160 & 359 & 5 & 82 & 22 & 6359 & 3.3 & 1.5 & 6.3 & 22464 & 2627 & 72 & 343 & 3.5 & 2378 & 5.6 & 23 \\
\hline 80 & 160 & 359 & 1 & 482 & 14 & 8497 & 3.6 & 8.4 & 17 & 20982 & 1988 & 50 & 640 & 13 & 3546 & 50 & 30 \\
\hline
\end{tabular}




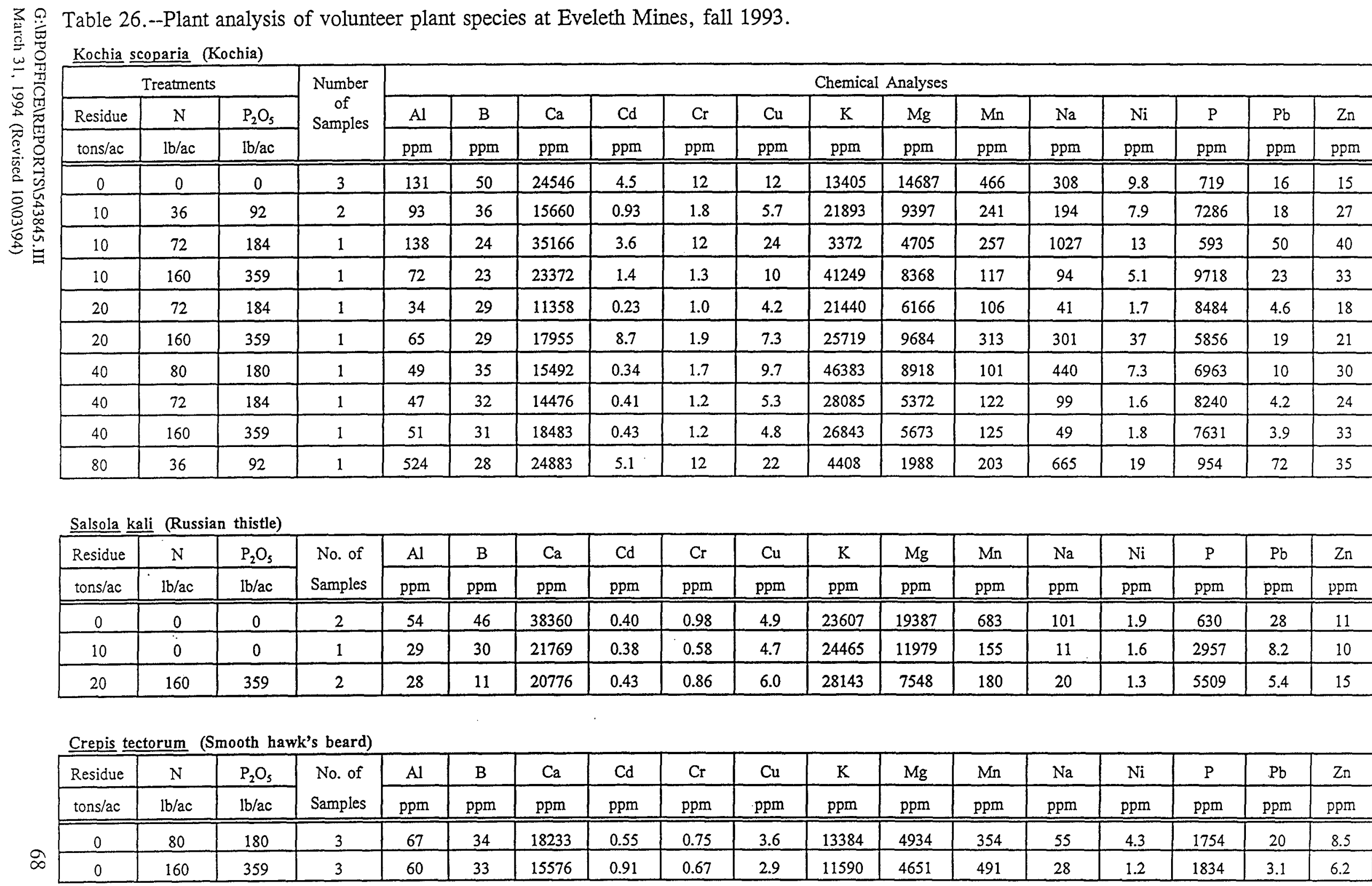




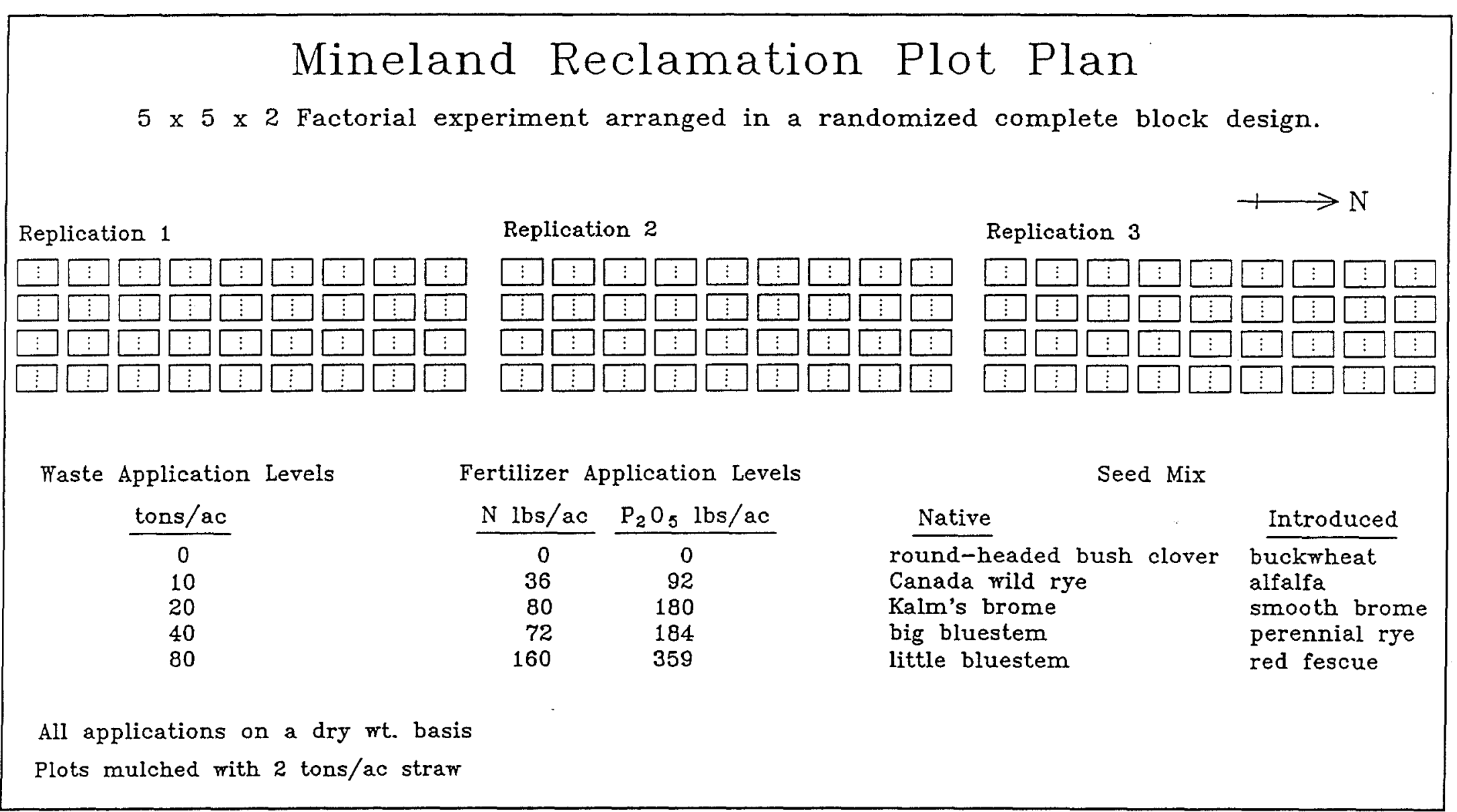

Figure 1.--Mineland reclamation plot plan at Eveleth Mines. 


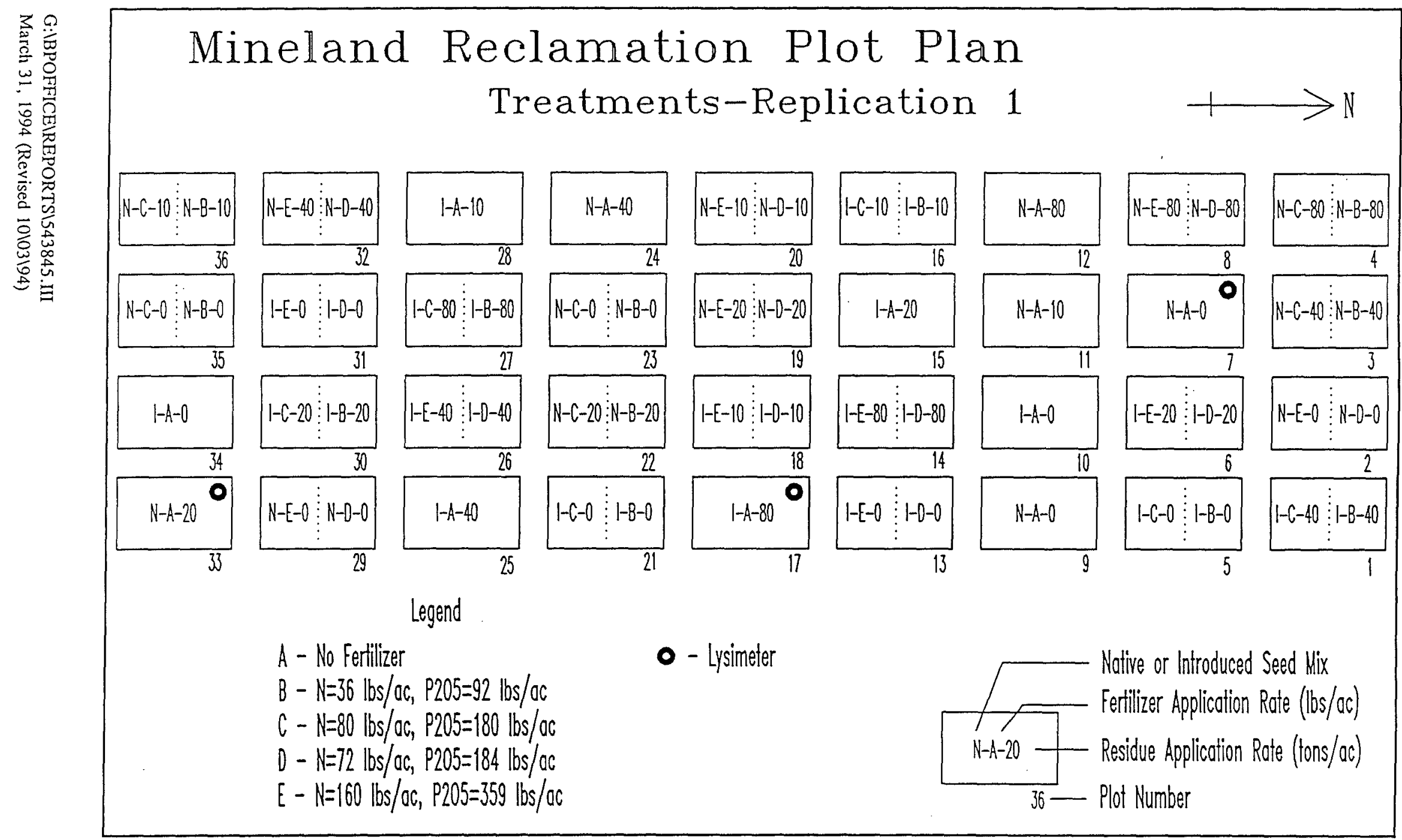

Figure 2.--Mineland reclamation plot plan for replication 1 at Eveleth Mines. 


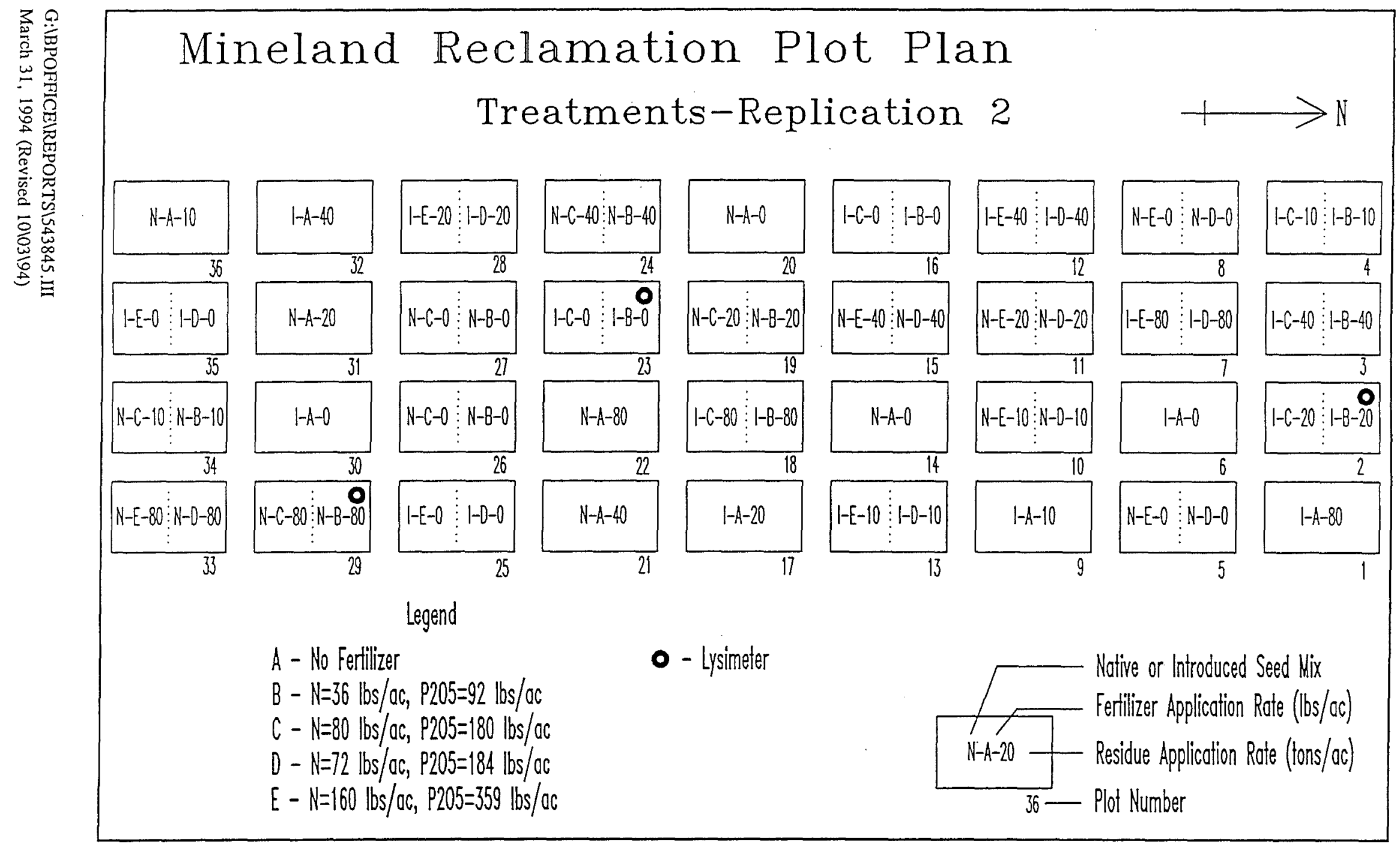

Figure 3.--Mineland reclamation plot plan for replication 2 at Eveleth Mines. 


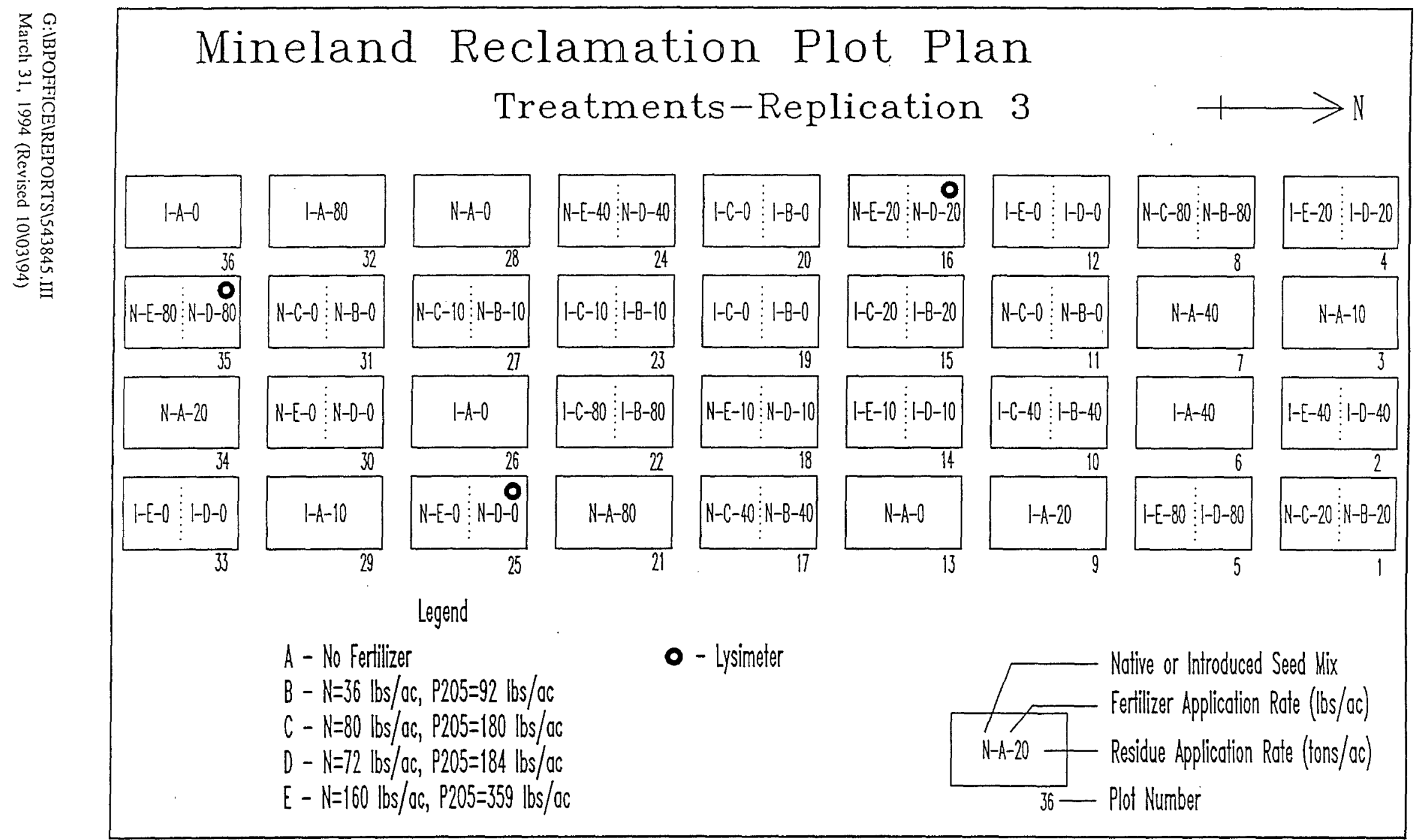

Figure 4.--Mineland reclamation plot plan for replication 3 at Eveleth Mines. 


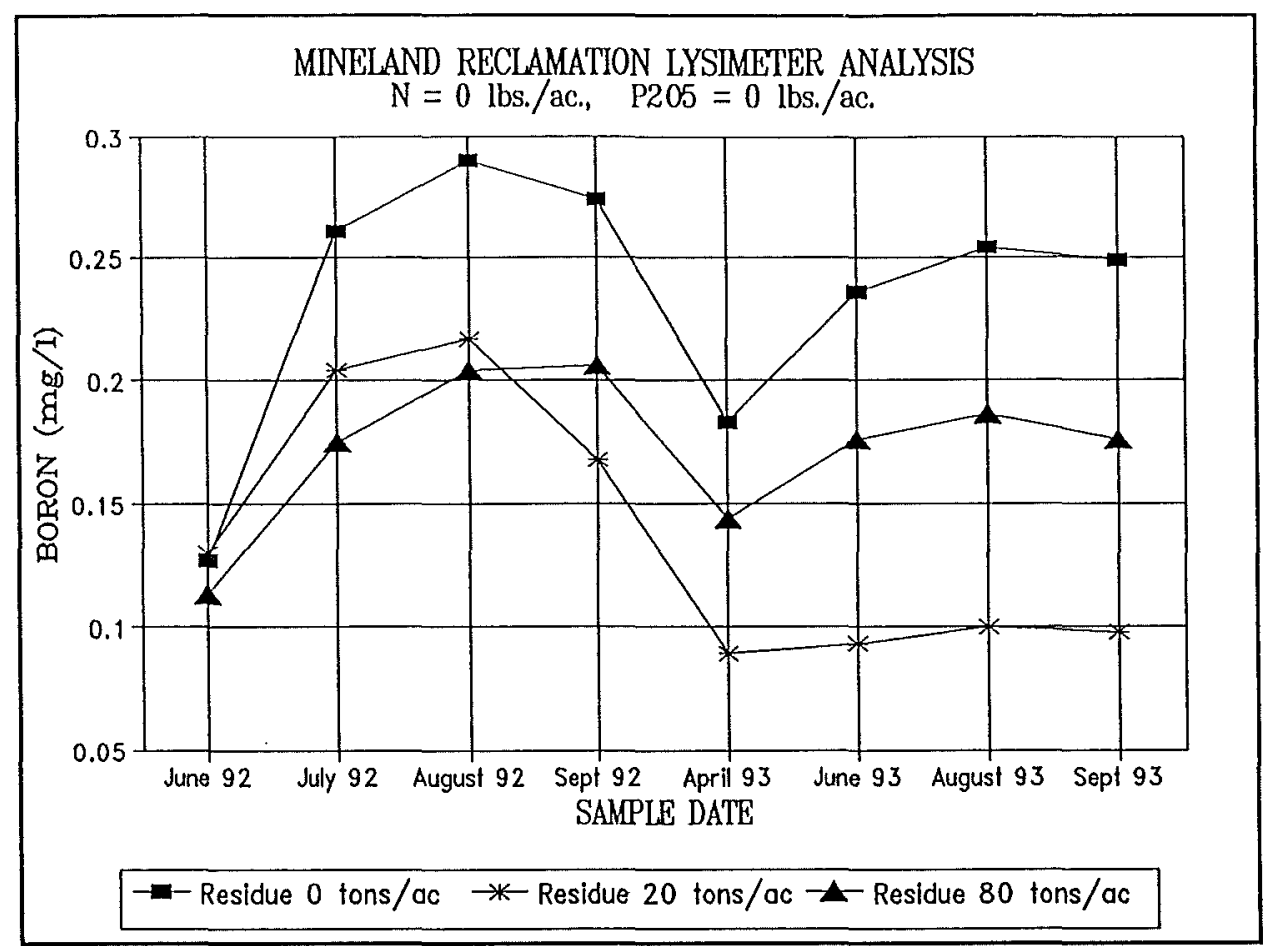

Figure 5.--Lysimeter analysis for boron on tailings amended with residue at 0,20 and 80 ton/acre without fertilizer.

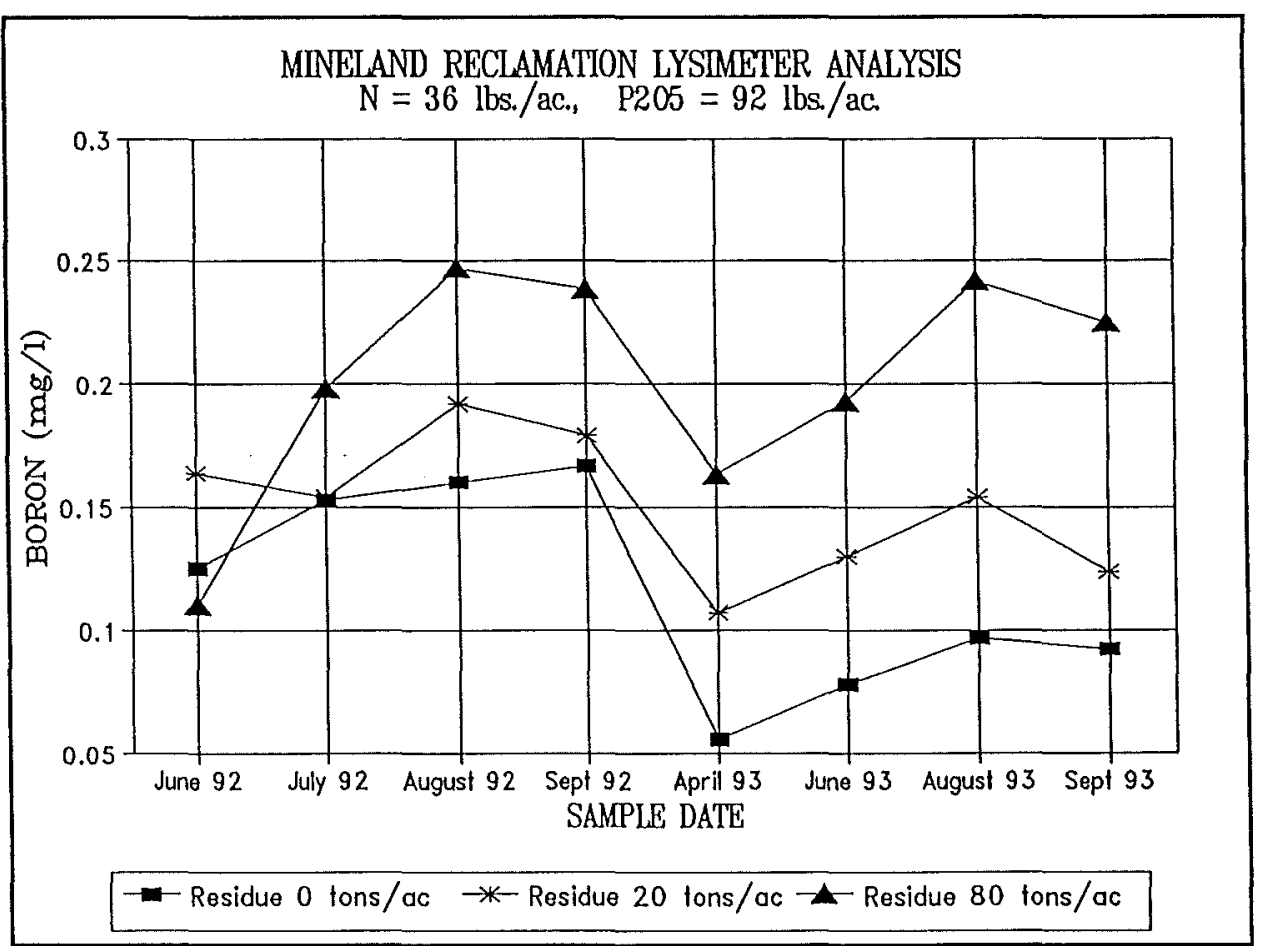

Figure 6.--Lysimeter analysis for boron on tailings amended with residue at 0,20 and $80 \mathrm{ton} / \mathrm{acre}$ and $200 \mathrm{lb} / \mathrm{acre} 18-46-0$. 


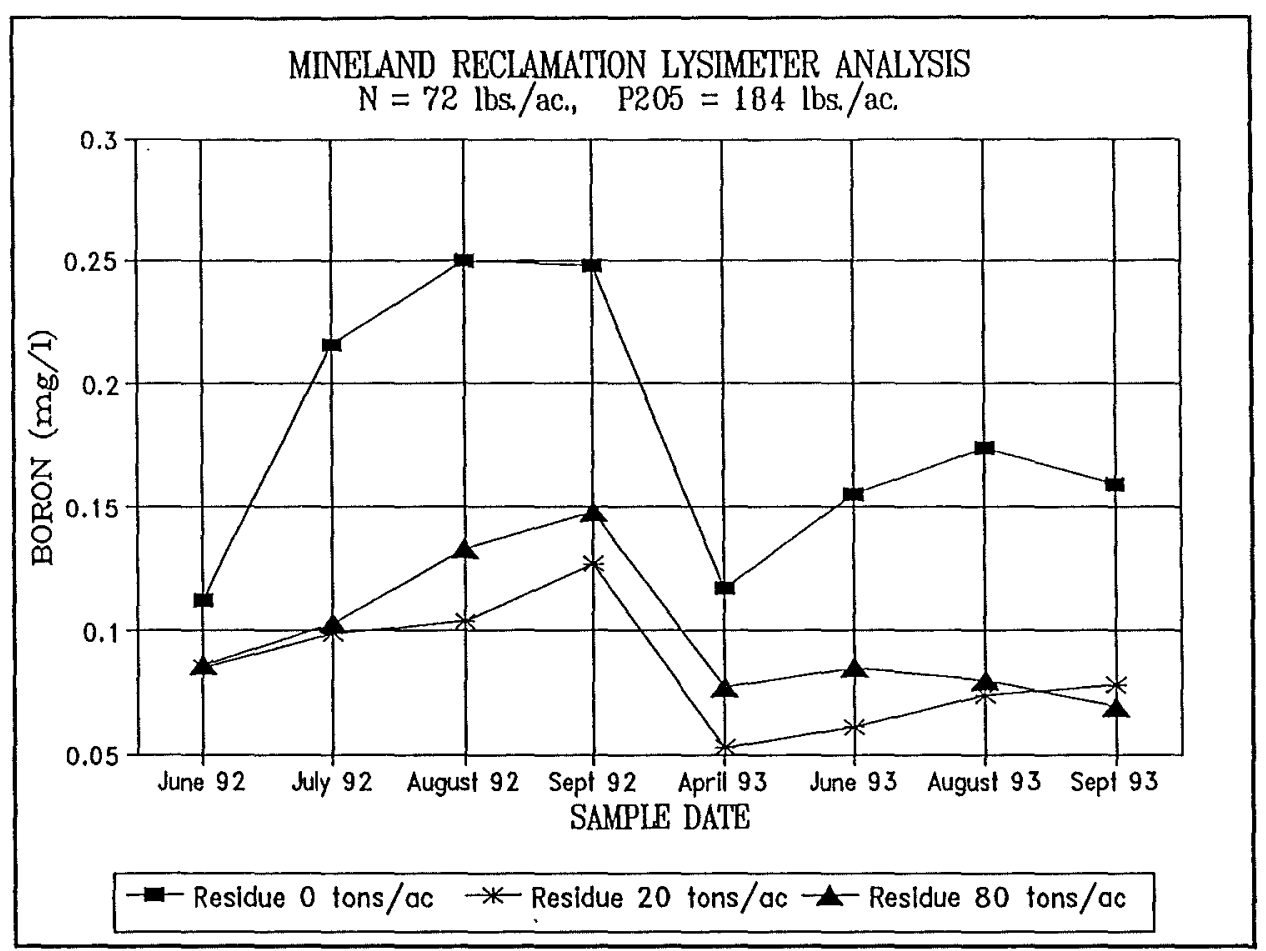

Figure 7.--Lysimeter analysis for boron on tailings amended with residue at 0,20 and 80 ton/acre and $400 \mathrm{lb} /$ acre $18-46-0$.

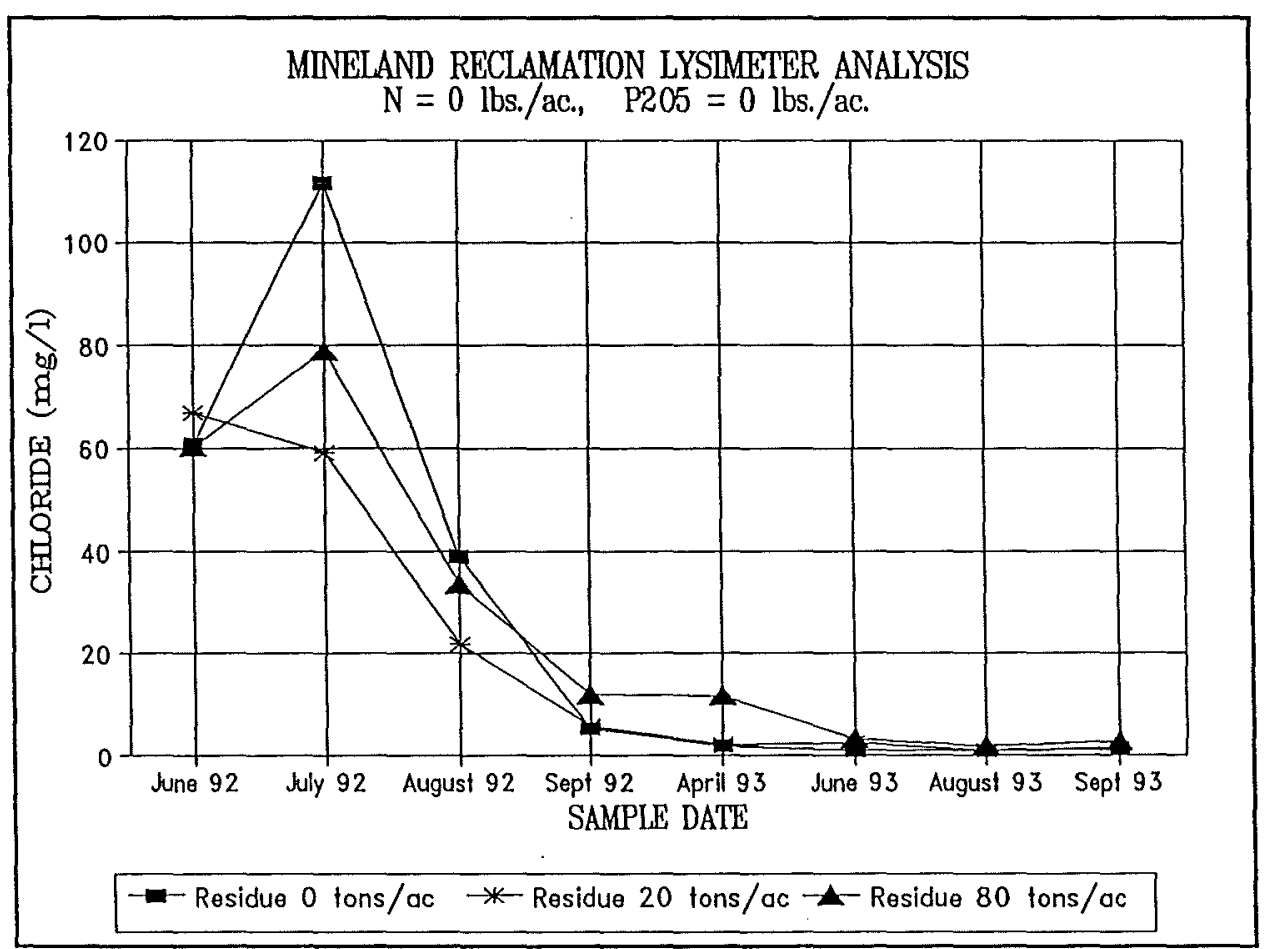

Figure 8.--Lysimeter analysis for chloride on tailings amended with residue at 0,20 and 80 ton/acre without fertilizer. 


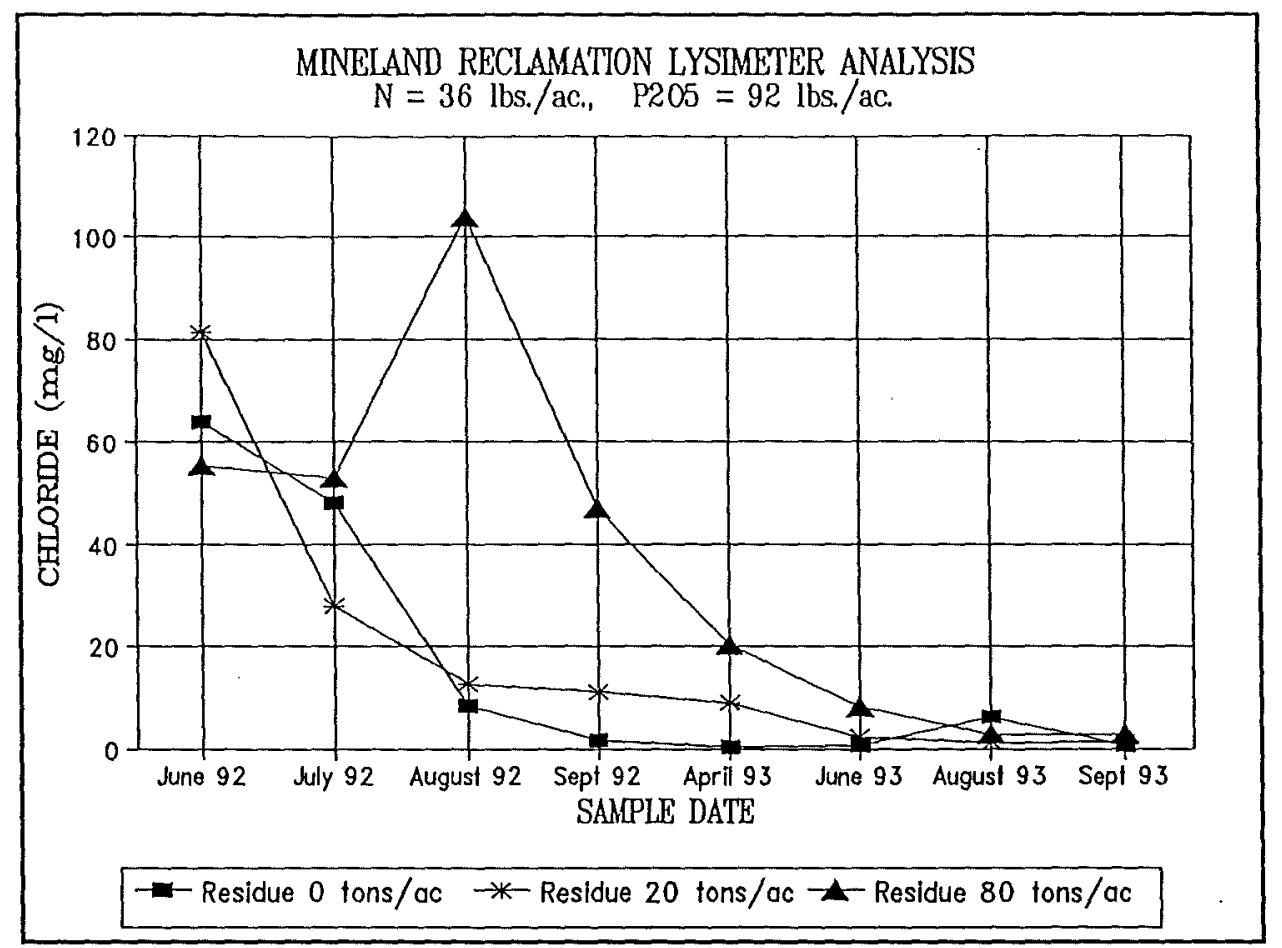

Figure 9.--Lysimeter analysis for chloride on tailings amended with residue at 0,20 and 80 ton/acre and $200 \mathrm{lb} / \mathrm{acre} 18-46-0$.

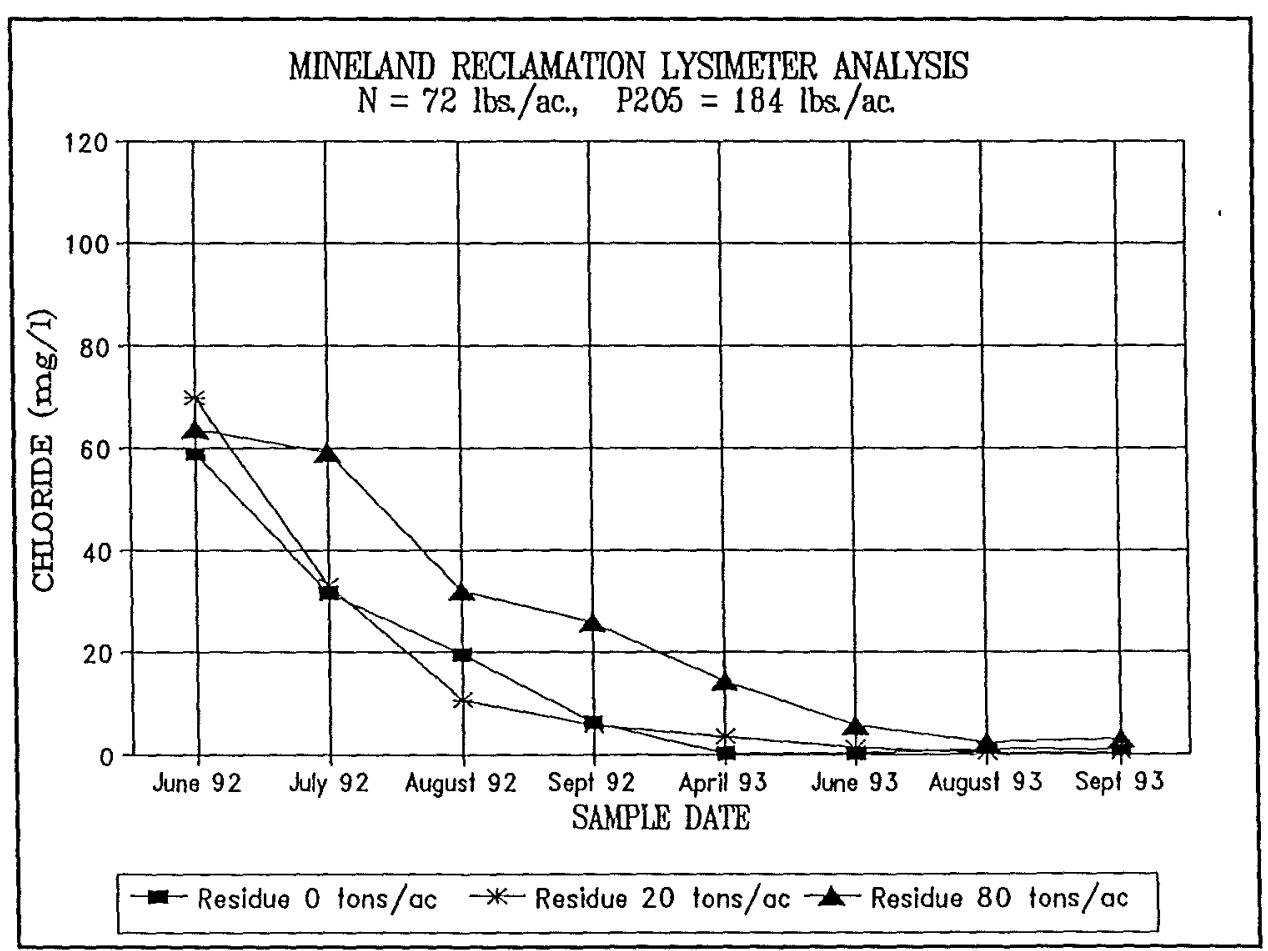

Figure 10.--Lysimeter analysis for chloride on tailings amended with residue at 0,20 and 80 ton/acre and $400 \mathrm{lb} / \mathrm{acre} 18-46-0$. 


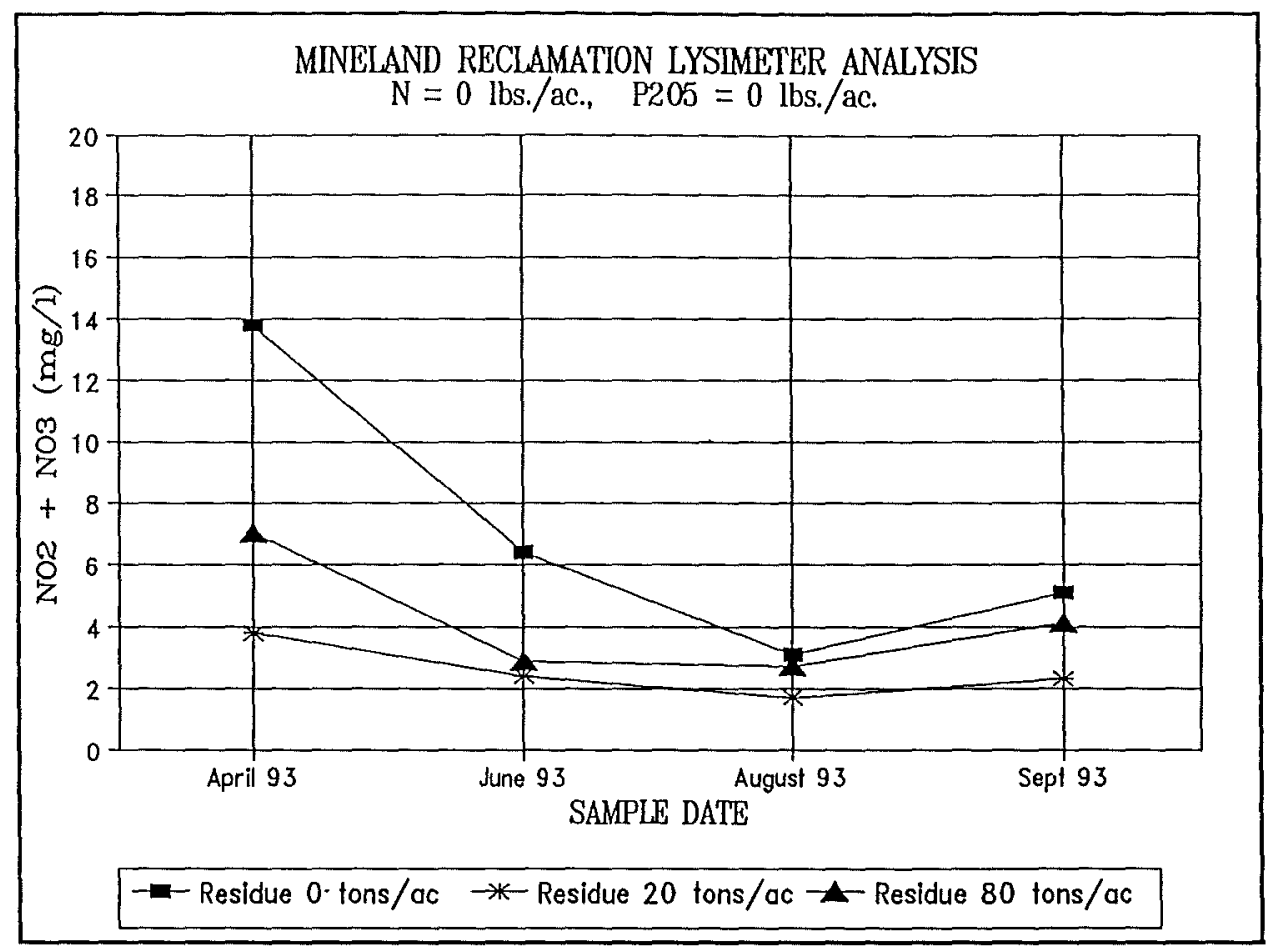

Figure 11.--Lysimeter analysis for nitrate-nitrogen on tailings amended with residue at 0,20 and 80 ton/acre without fertilizer.

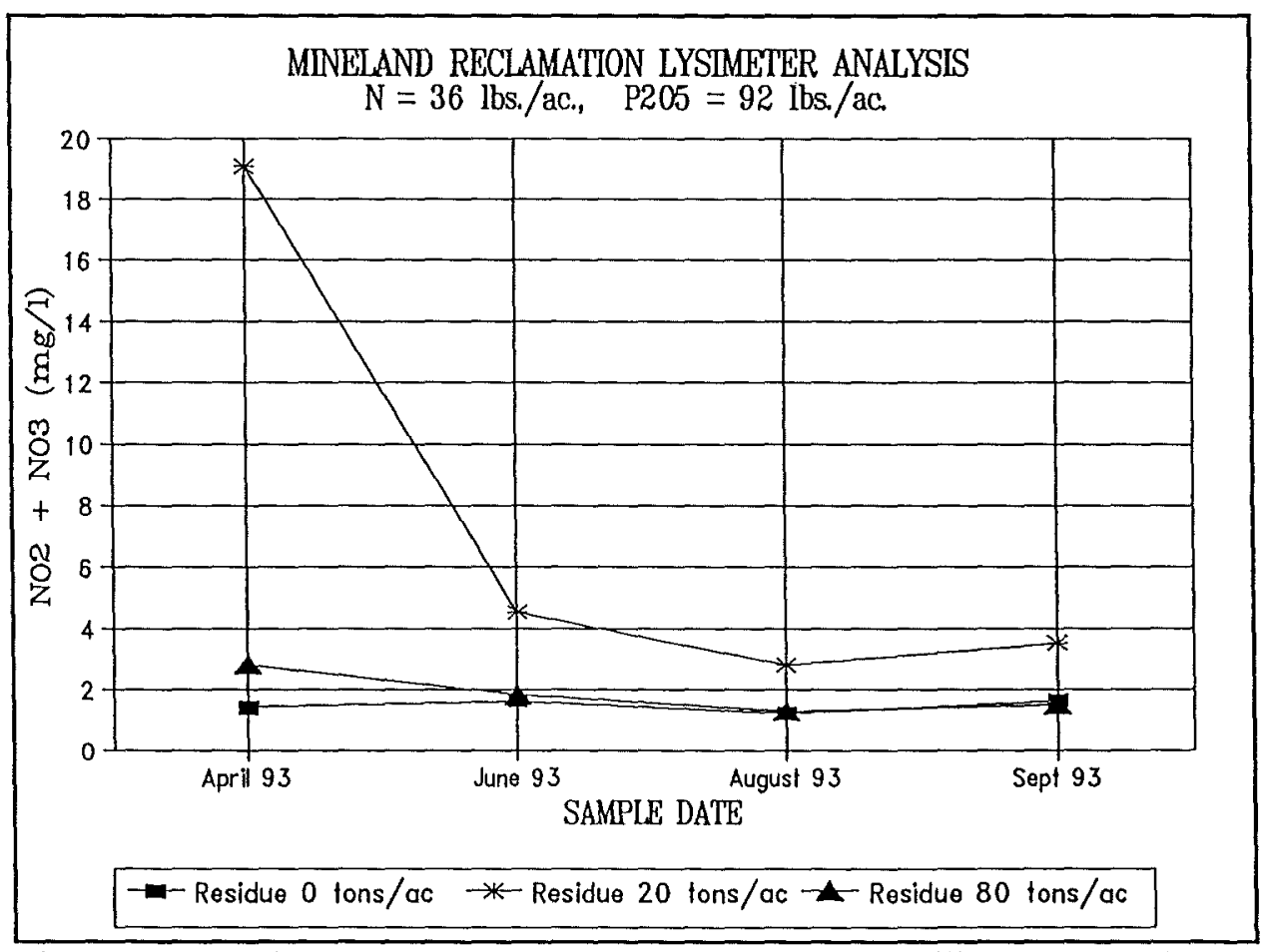

Figure 12.--Lysimeter analysis for nitrate-nitrogen on tailings amended with residue at 0,20 and 80 ton/acre and $200 \mathrm{lb} /$ acre $18-46-0$. 


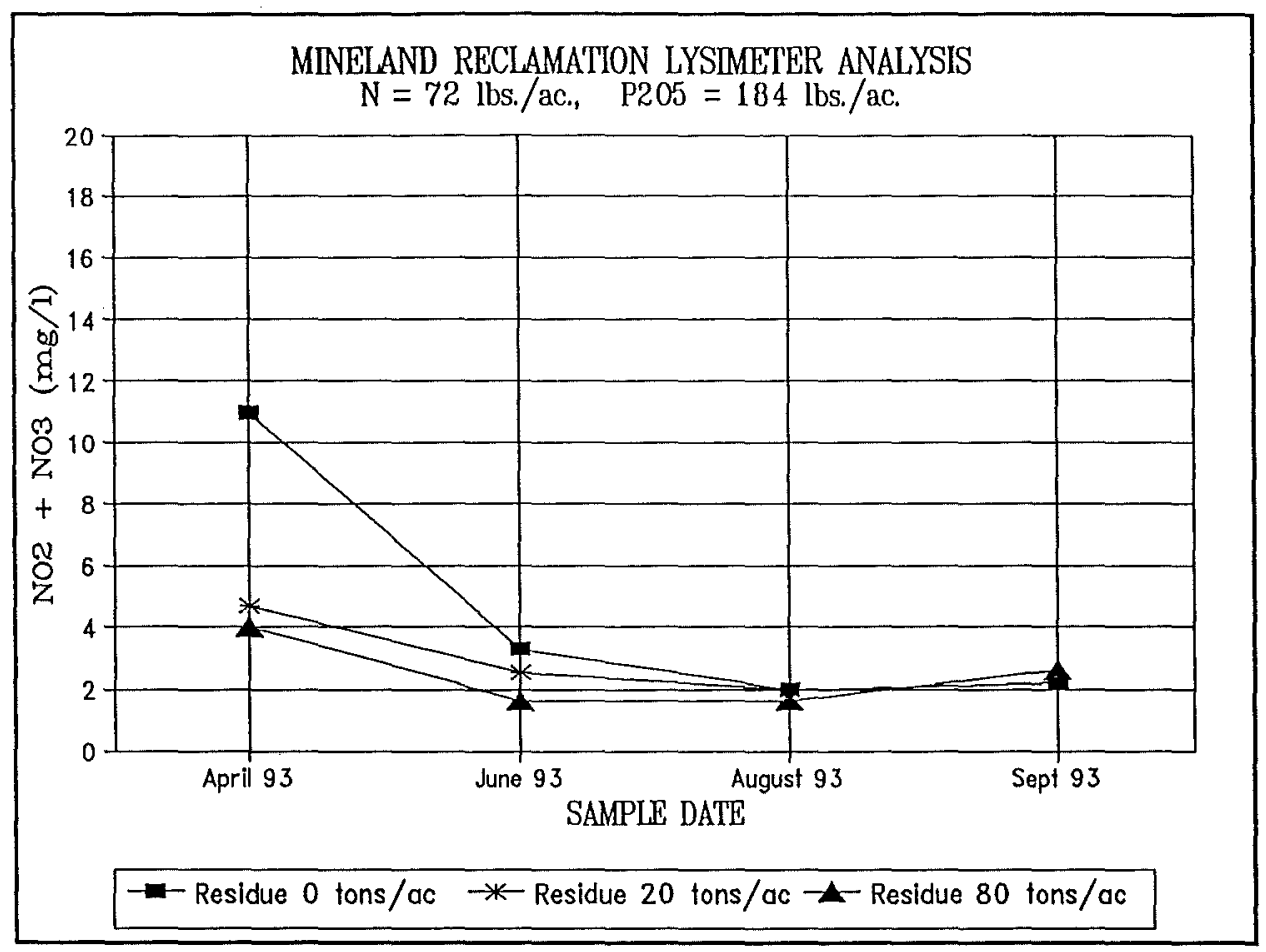

Figure 13.--Lysimeter analysis for nitrate-nitrogen on tailings amended with residue at 0,20 and $80 \mathrm{ton} / \mathrm{acre}$ and $400 \mathrm{lb} / \mathrm{acre} 18-46-0$.

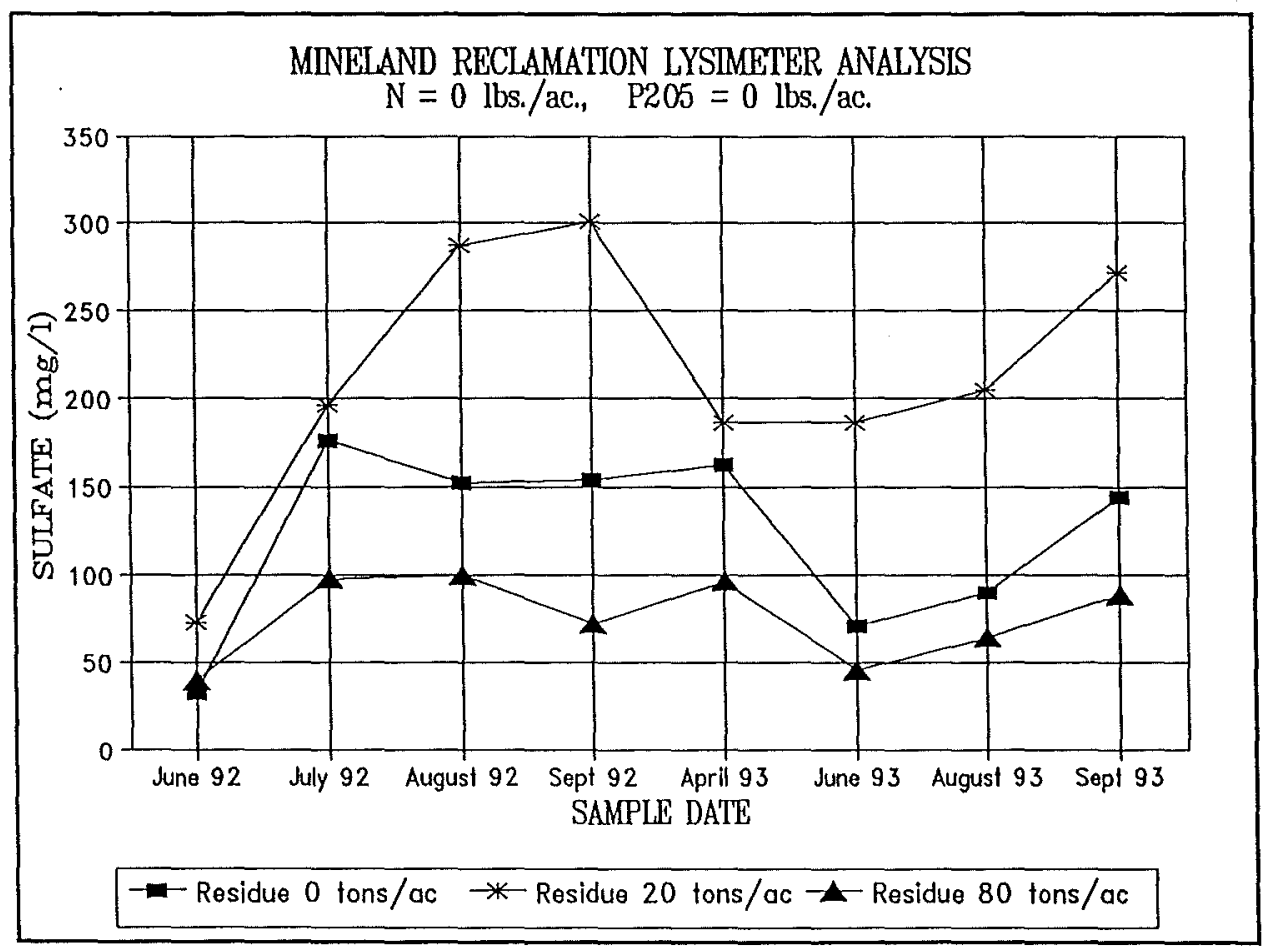

Figure 14.--Lysimeter analysis for sulfate-sulfur on tailings amended with residue at 0,20 and 80 ton/ac without fertilizer. 


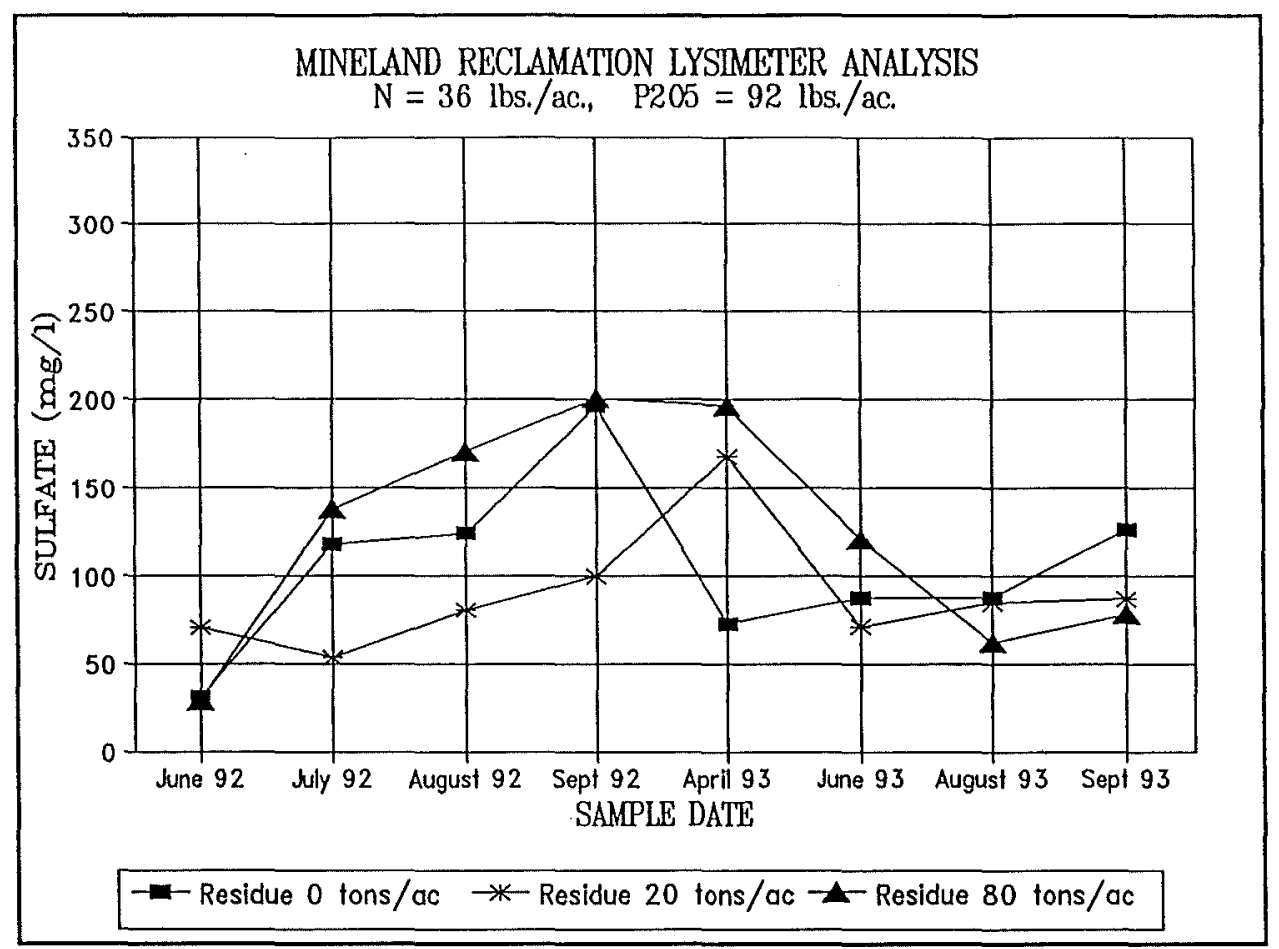

Figure 15.-Lysimeter analysis for sulfate-sulfur on tailings amended with residue at 0,20 and 80 ton/acre and $200 \mathrm{lb} /$ acre $18-46-0$.

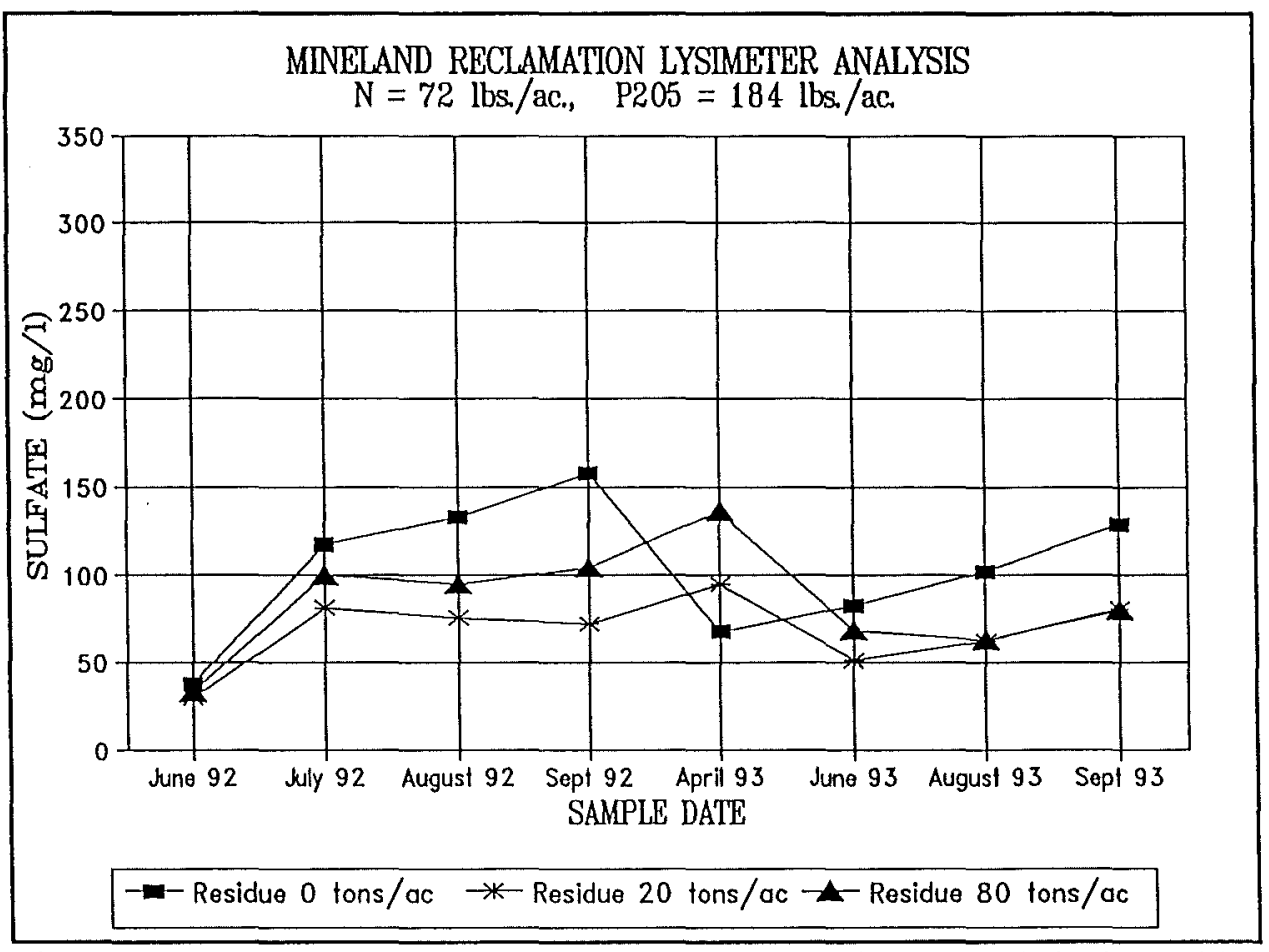

Figure 16.--Lysimeter analysis for sulfate-sulfur on tailings amended with residue at 0,20 and 80 ton/acre and $400 \mathrm{lb} / \mathrm{acre} 18-46-0$. 


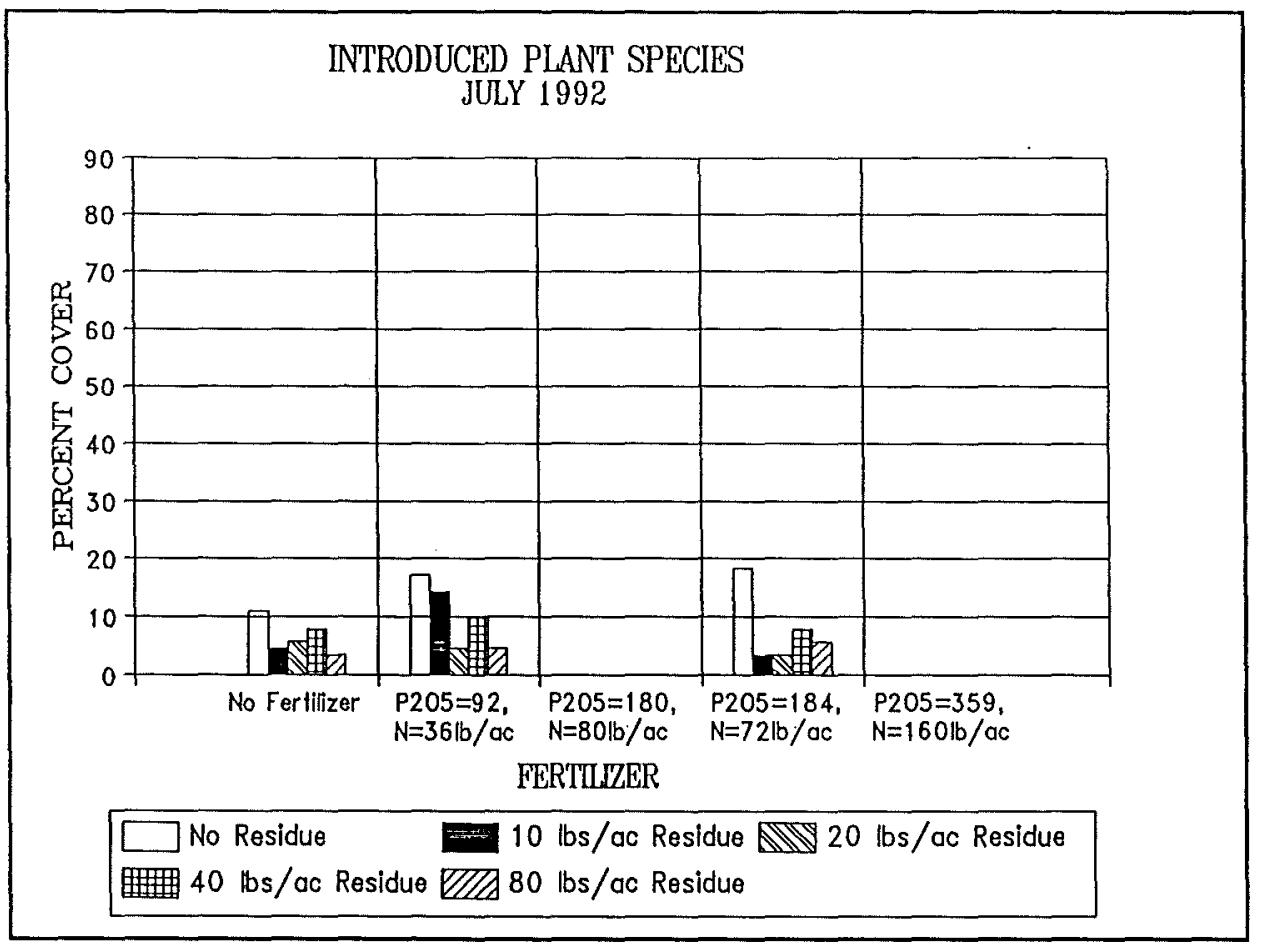

Figure 17.--The mean percent vegetative cover for introduced plant species measured in July 1992 by fertilizer treatment.

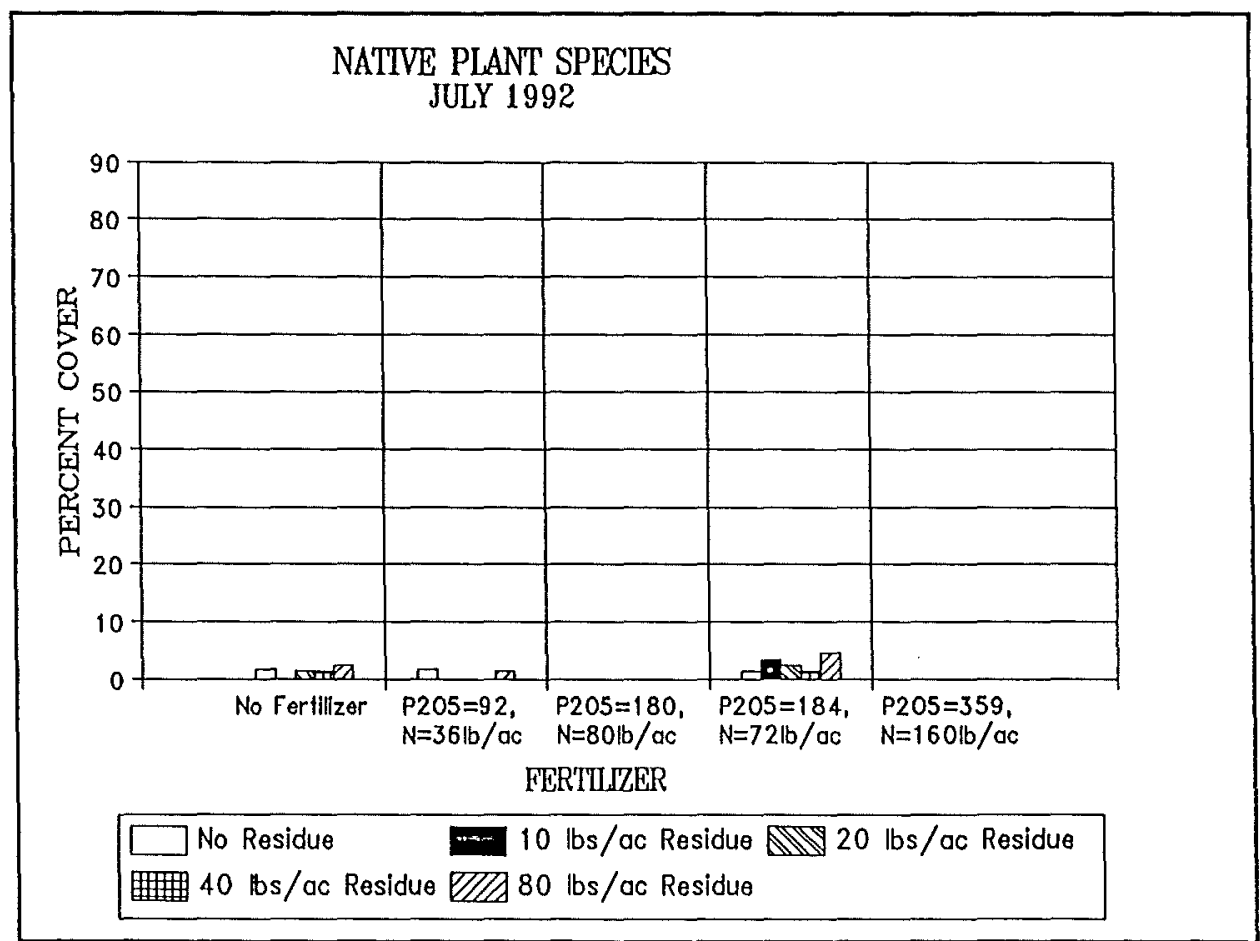

Figure 18.--The mean percent vegetative cover for native plant species measured in July 1992 by fertilizer treatment. 


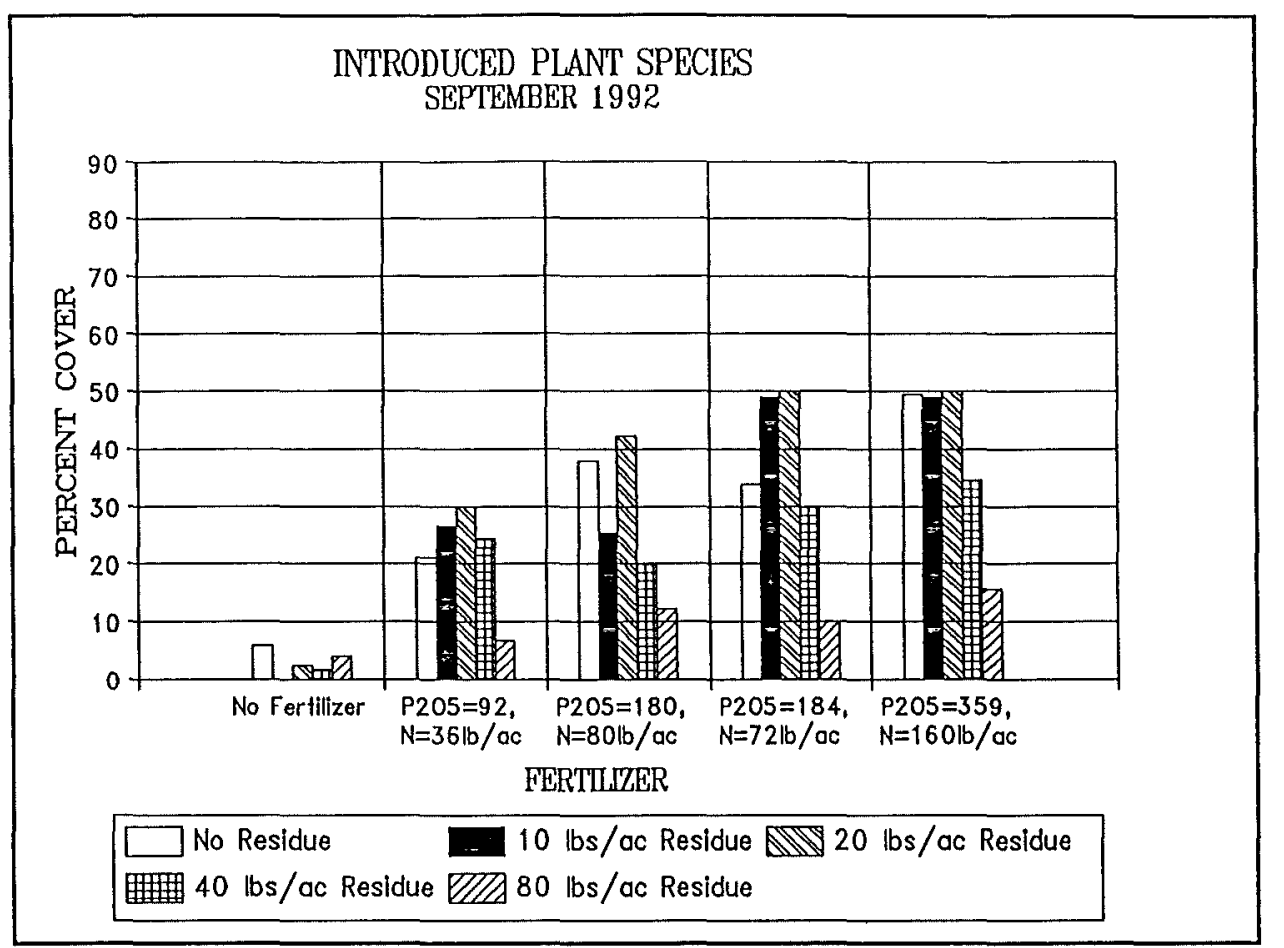

Figure 19.--The mean percent vegetative cover for introduced plant species measured in September 1992 by fertilizer treatment.

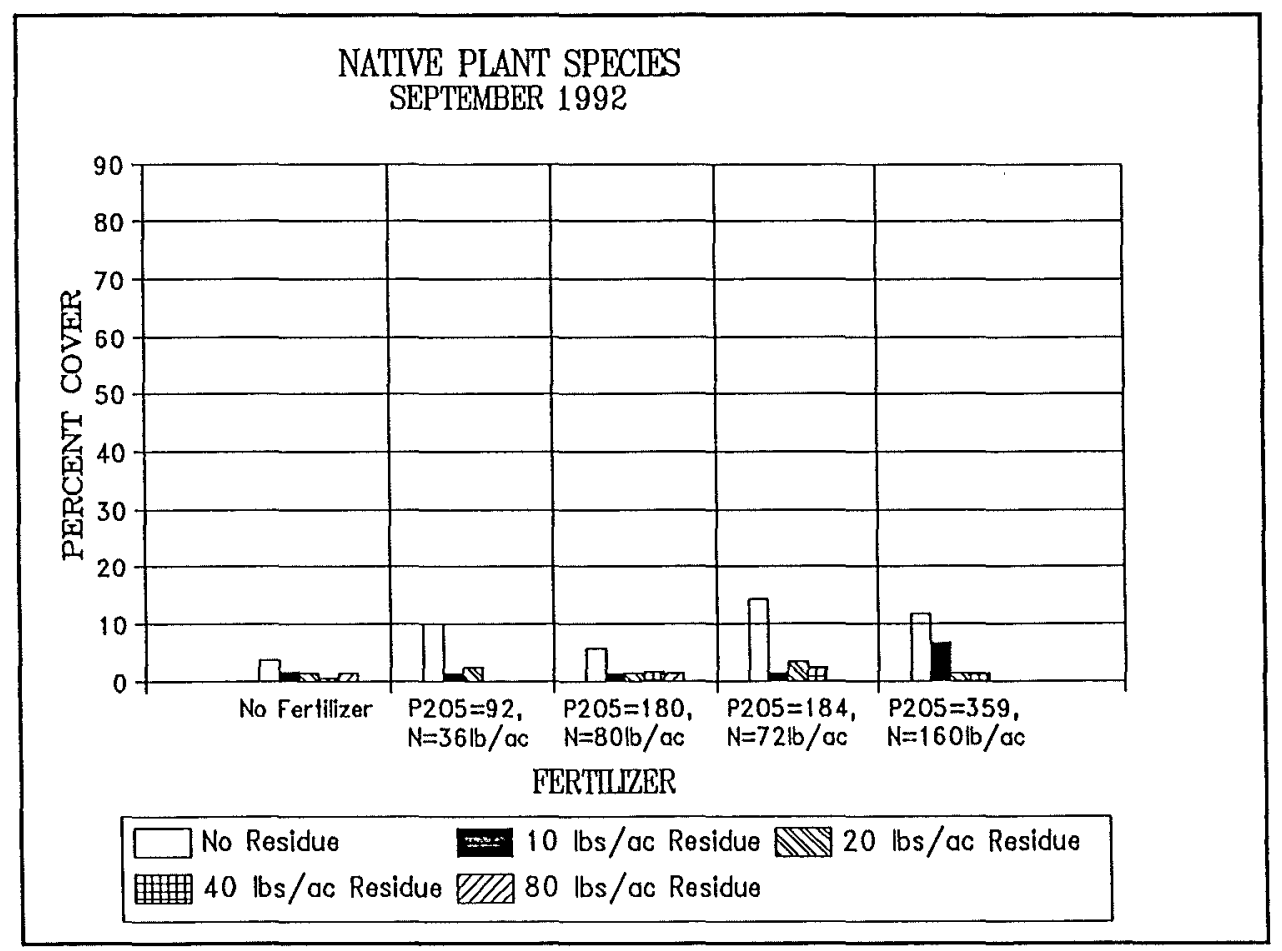

Figure 20.--The mean percent vegetative cover for native plant species measured in September 1992 by fertilizer treatment. 


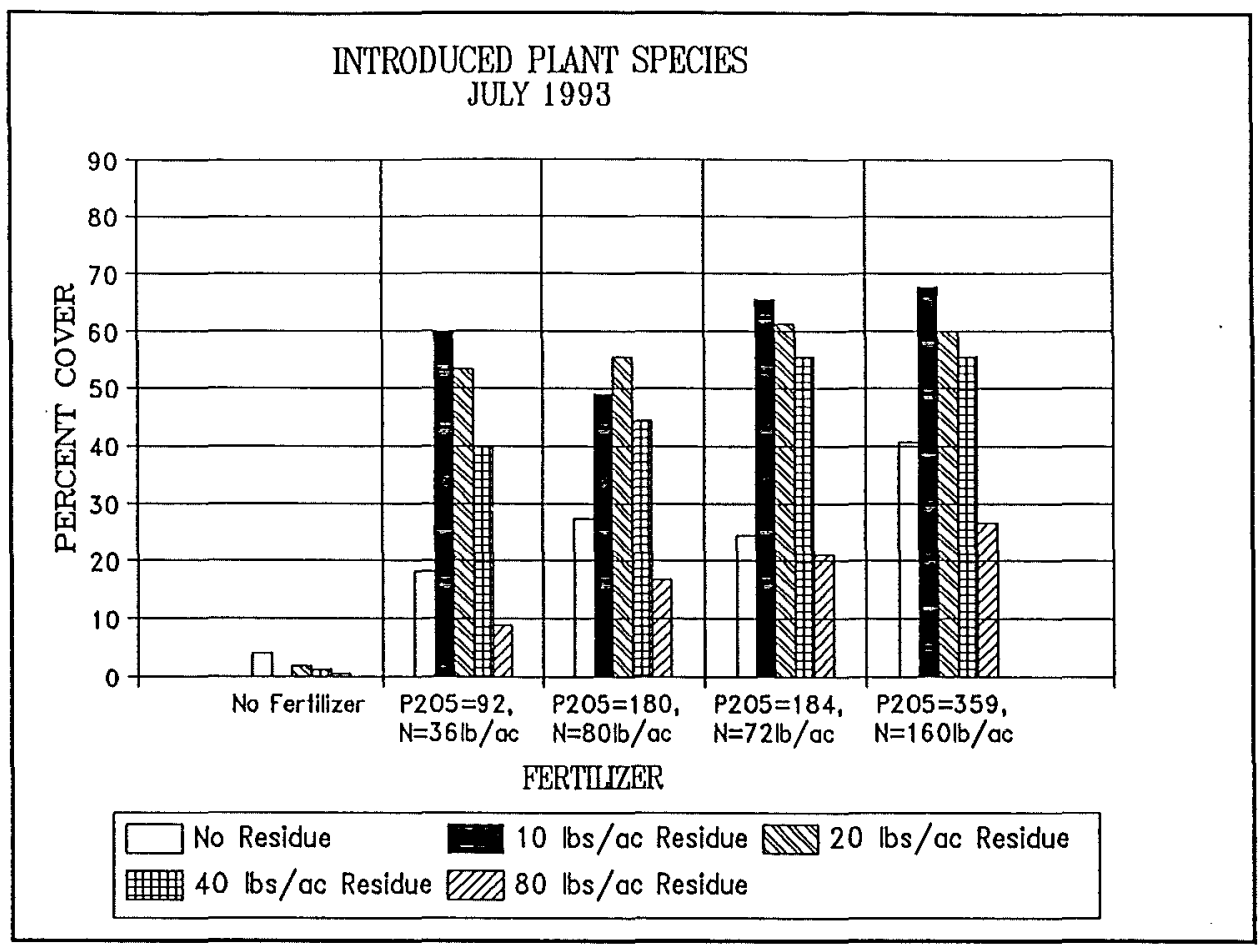

Figure 21.--The mean percent vegetative cover for introduced plant species measured in July 1993 by fertilizer treatment.

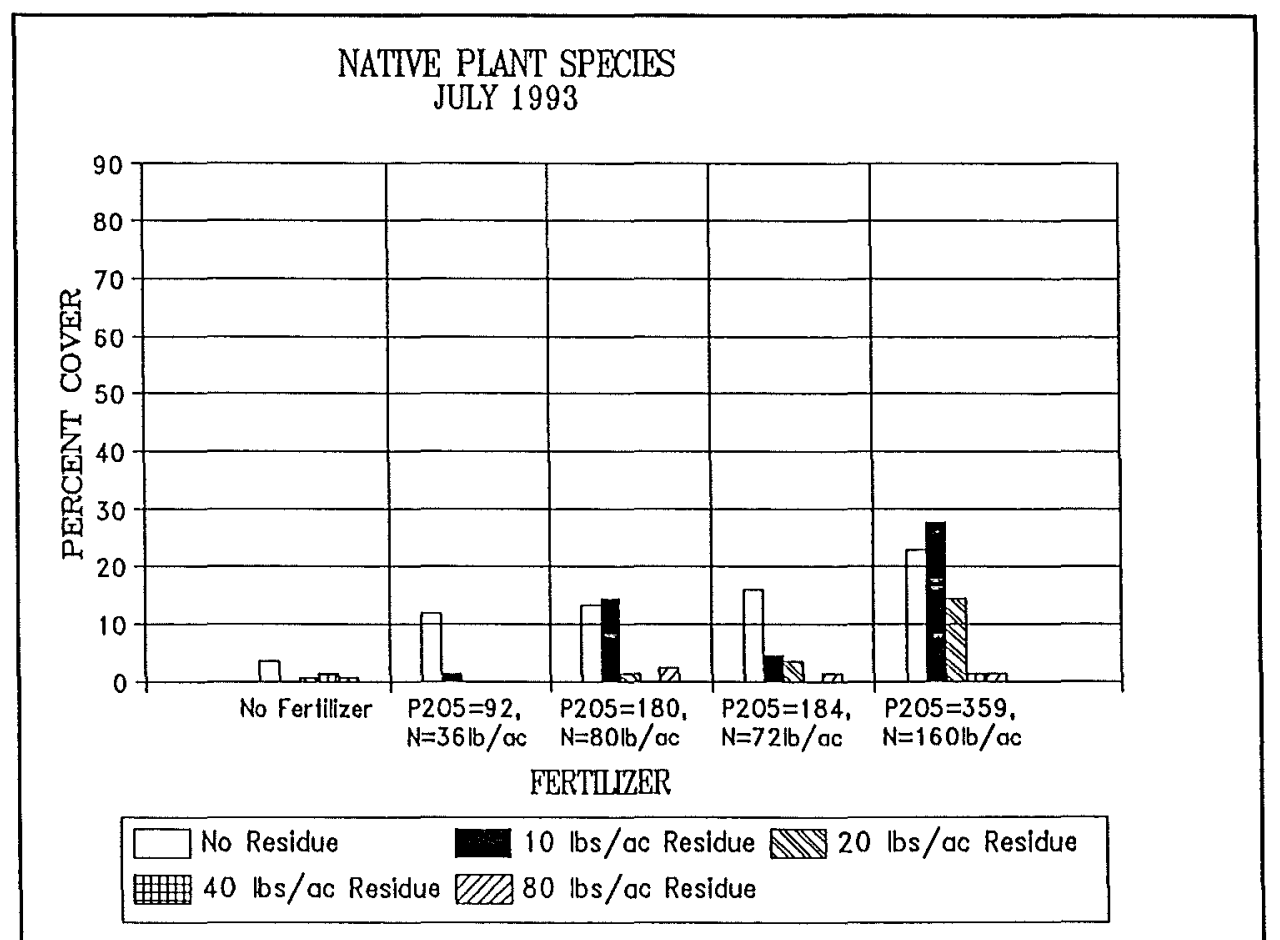

Figure 22.--The mean percent vegetative cover for native plant species measured in July 1993 by fertilizer treatment. 


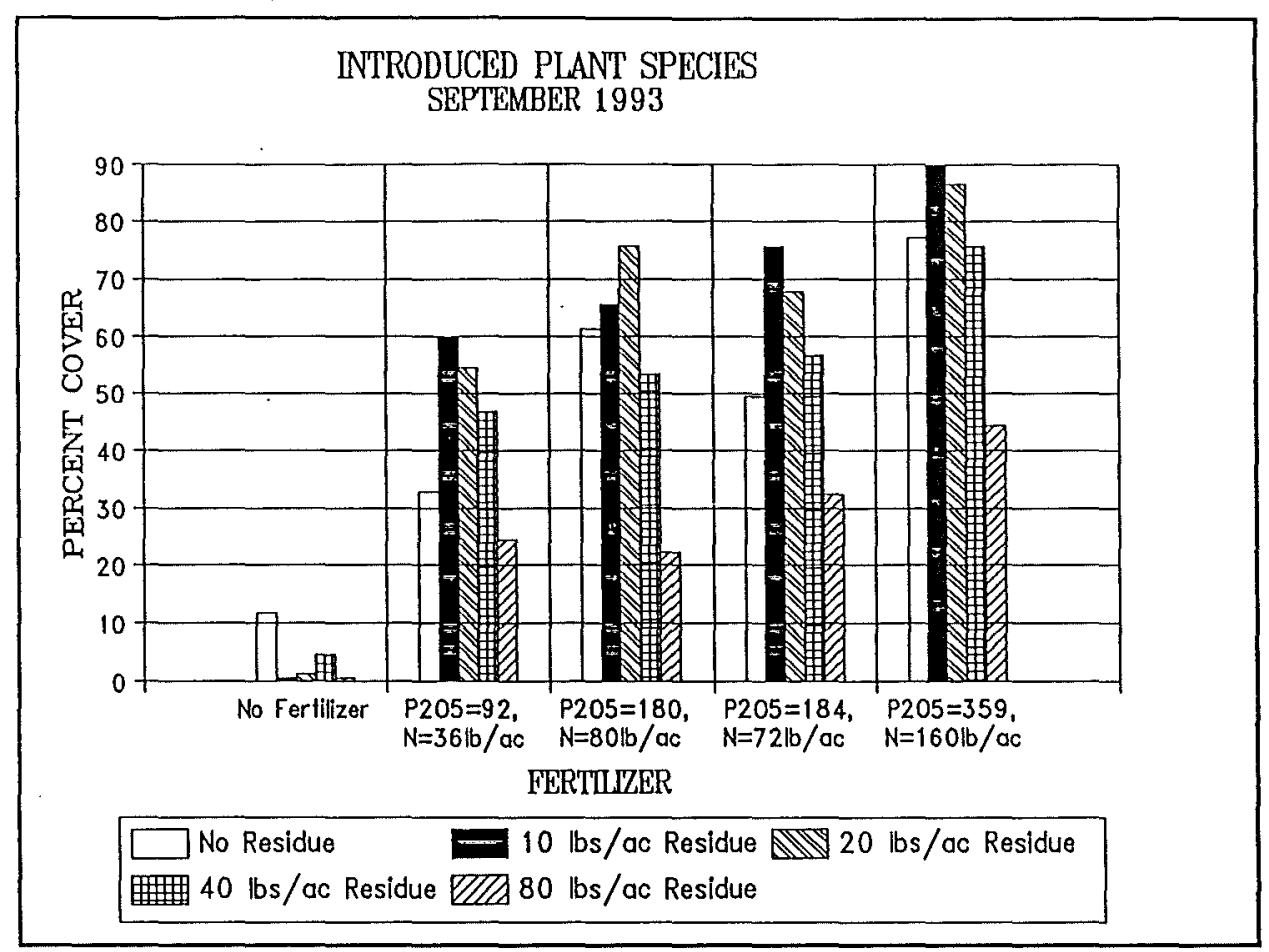

Figure 23.--The mean percent vegetative cover for introduced plant species measured in September 1993 by fertilizer treatment.

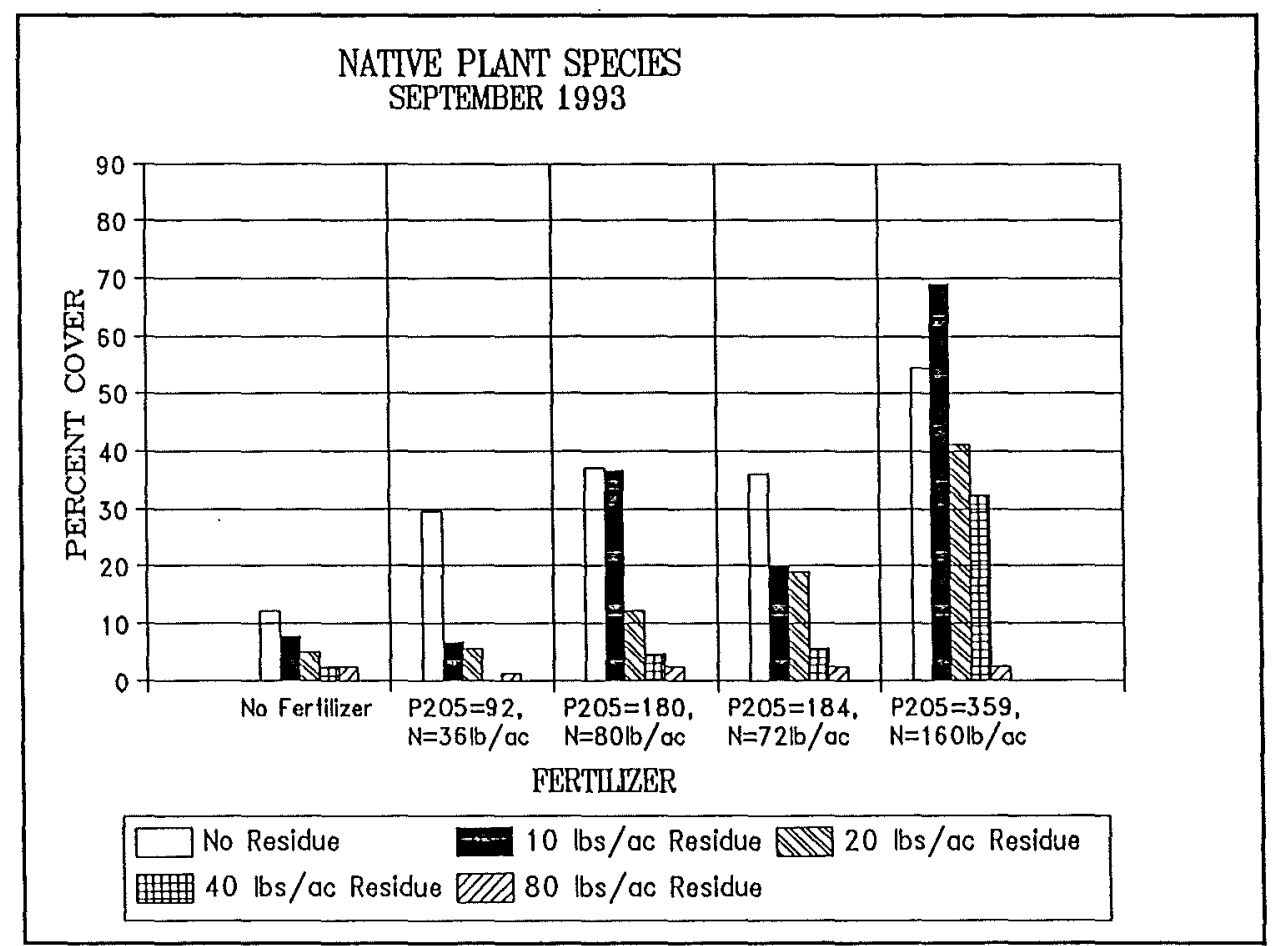

Figure 24.--The mean percent vegetative cover for native plant species measured in September 1993 by fertilizer treatment. 


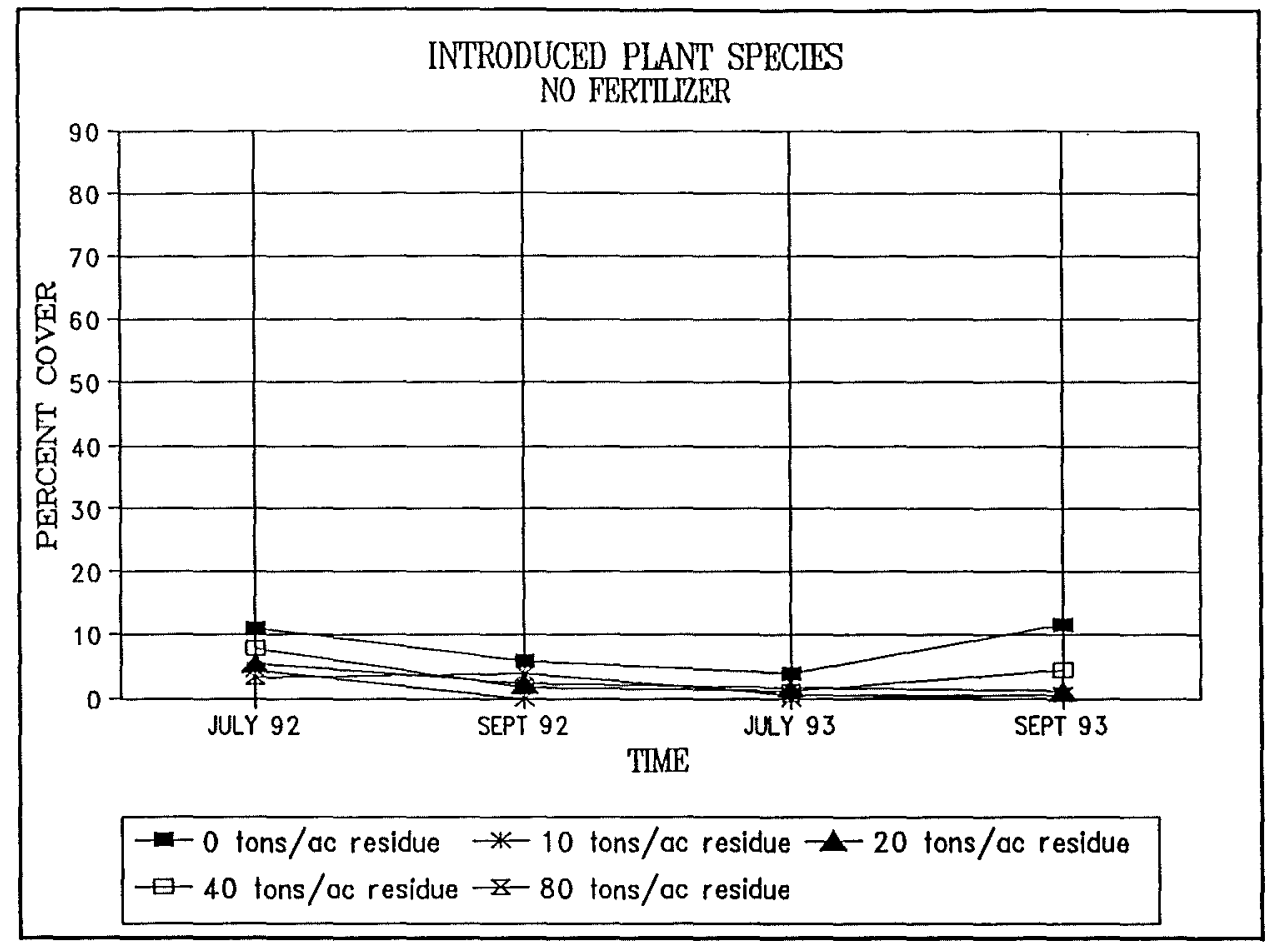

Figure 25.--The mean percent cover, over time, for introduced species treated with de-inking residue and no commercial fertilizer.

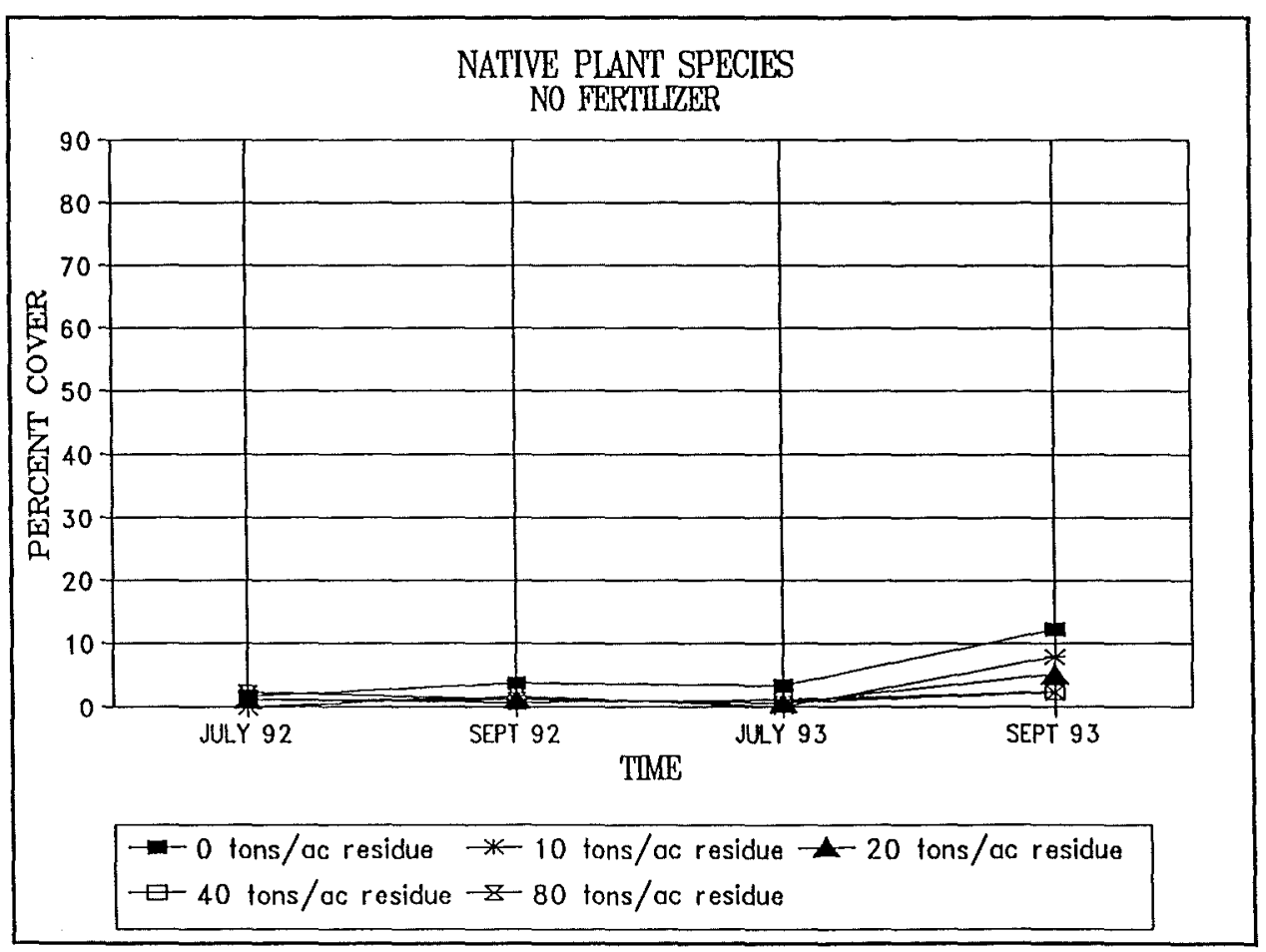

Figure 26.--The mean percent cover, over time, for native species treated with de-inking residue and no commercial fertilizer. 


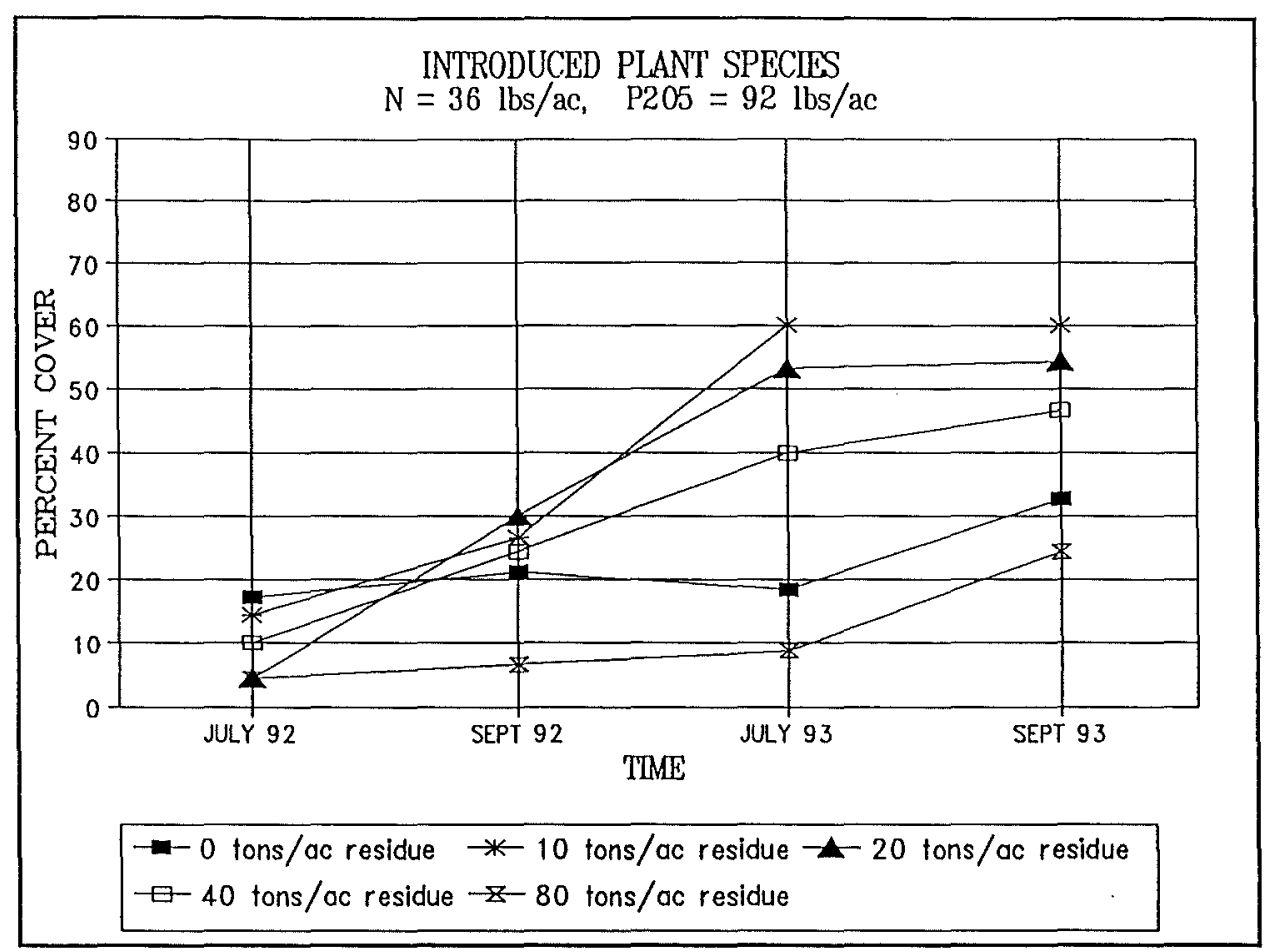

Figure 27.--The mean percent cover, over time, for introduced species treated with de-inking residue and commercial fertilizer at $\mathrm{N}=36 \mathrm{lbs} / \mathrm{ac}$ and $\mathrm{P}_{2} \mathrm{O}_{5}=92$ lbs/ac.

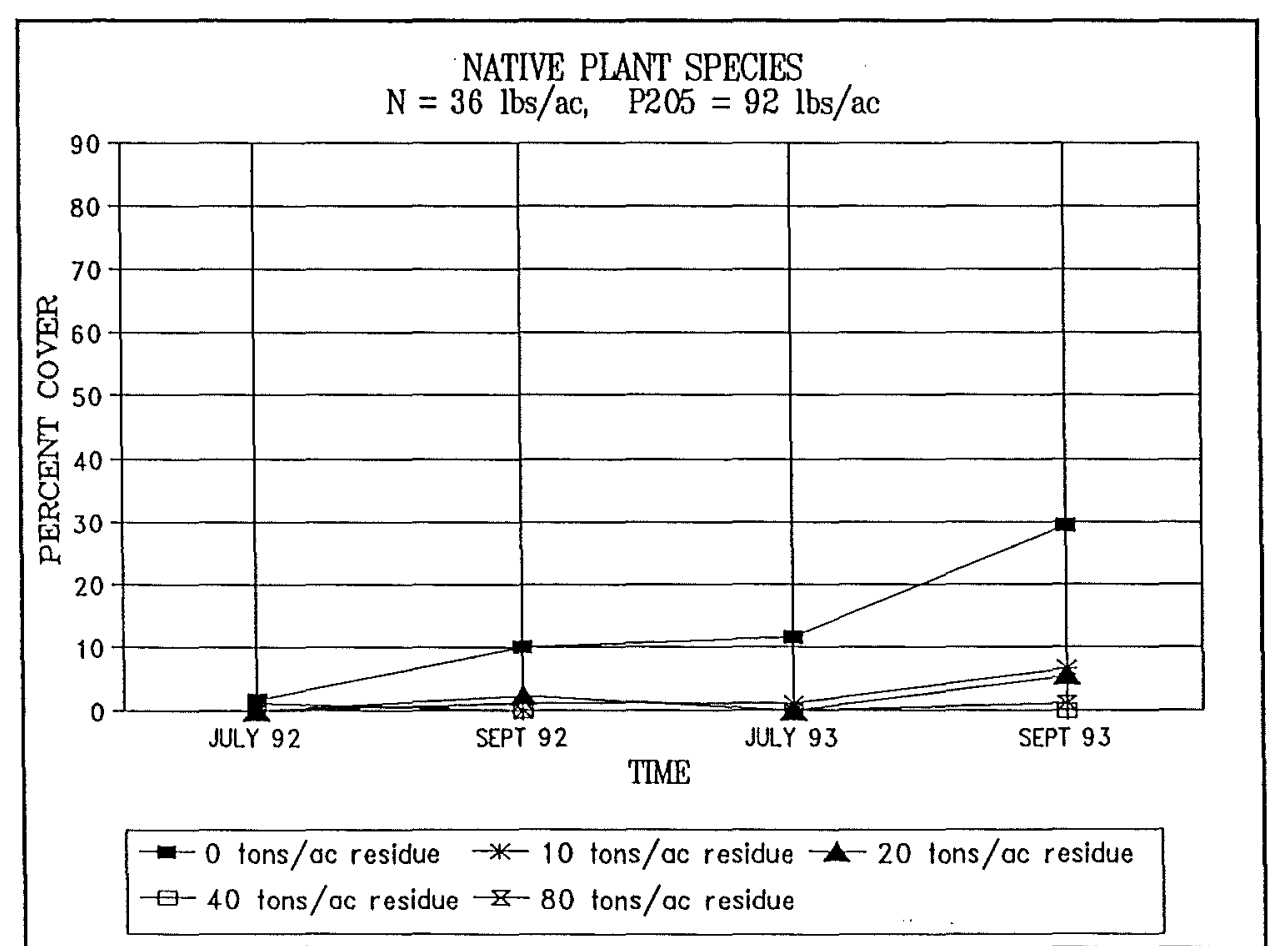

Figure 28.--The mean percent cover, over time, for native species treated with de-inking residue and commercial fertilizer at $\mathrm{N}=36 \mathrm{lbs} / \mathrm{ac}$ and $\mathrm{P}_{2} \mathrm{O}_{5}=92 \mathrm{lbs} / \mathrm{ac}$. 


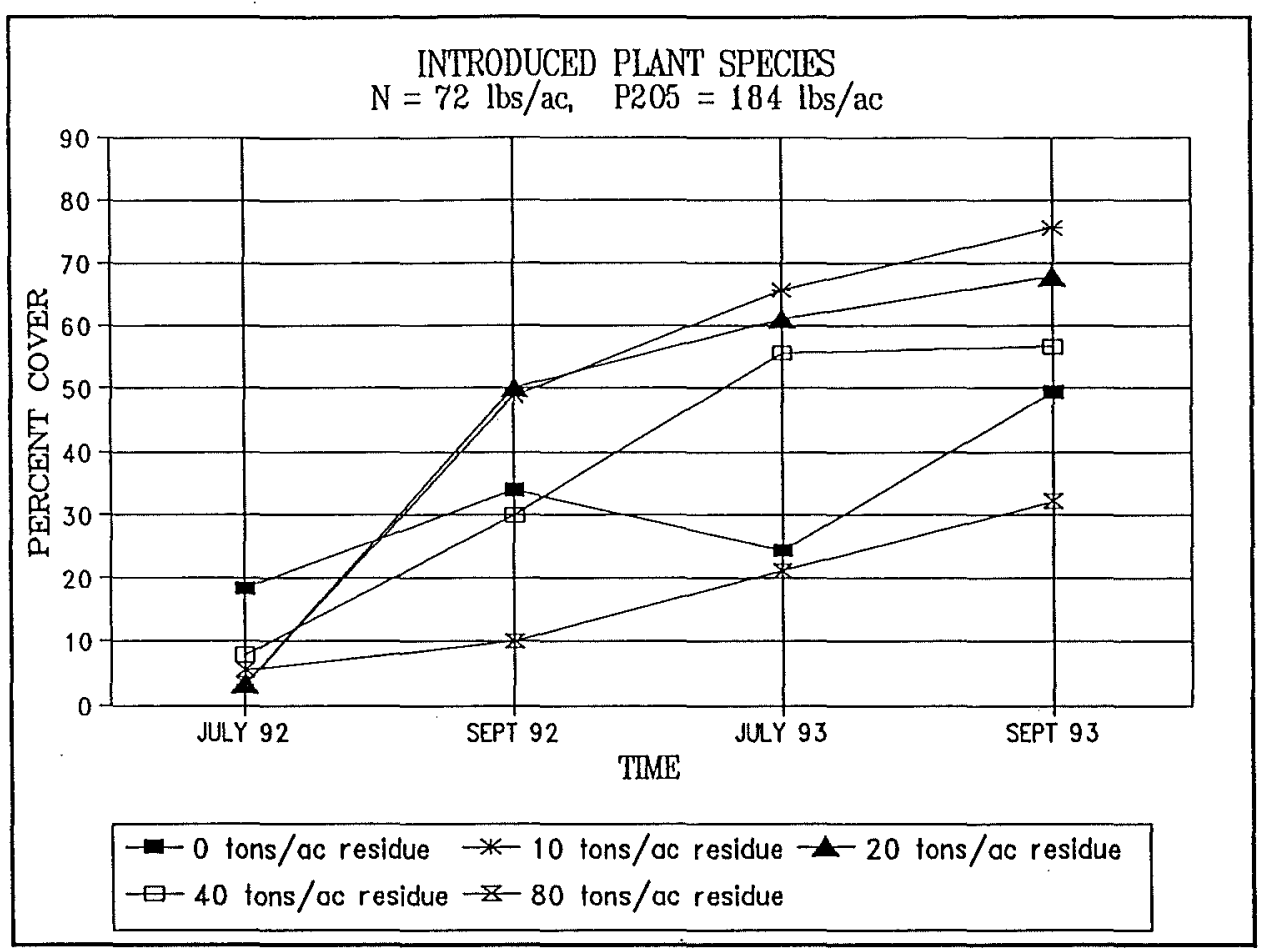

Figure 29.--The mean percent cover, over time, for introduced species treated with de-inking residue and commercial fertilizer at $\mathrm{N}=72 \mathrm{lb} / \mathrm{acre}$ and $\mathrm{P}_{2} \mathrm{O}_{5}=184$ $\mathrm{lb} / \mathrm{acre}$.

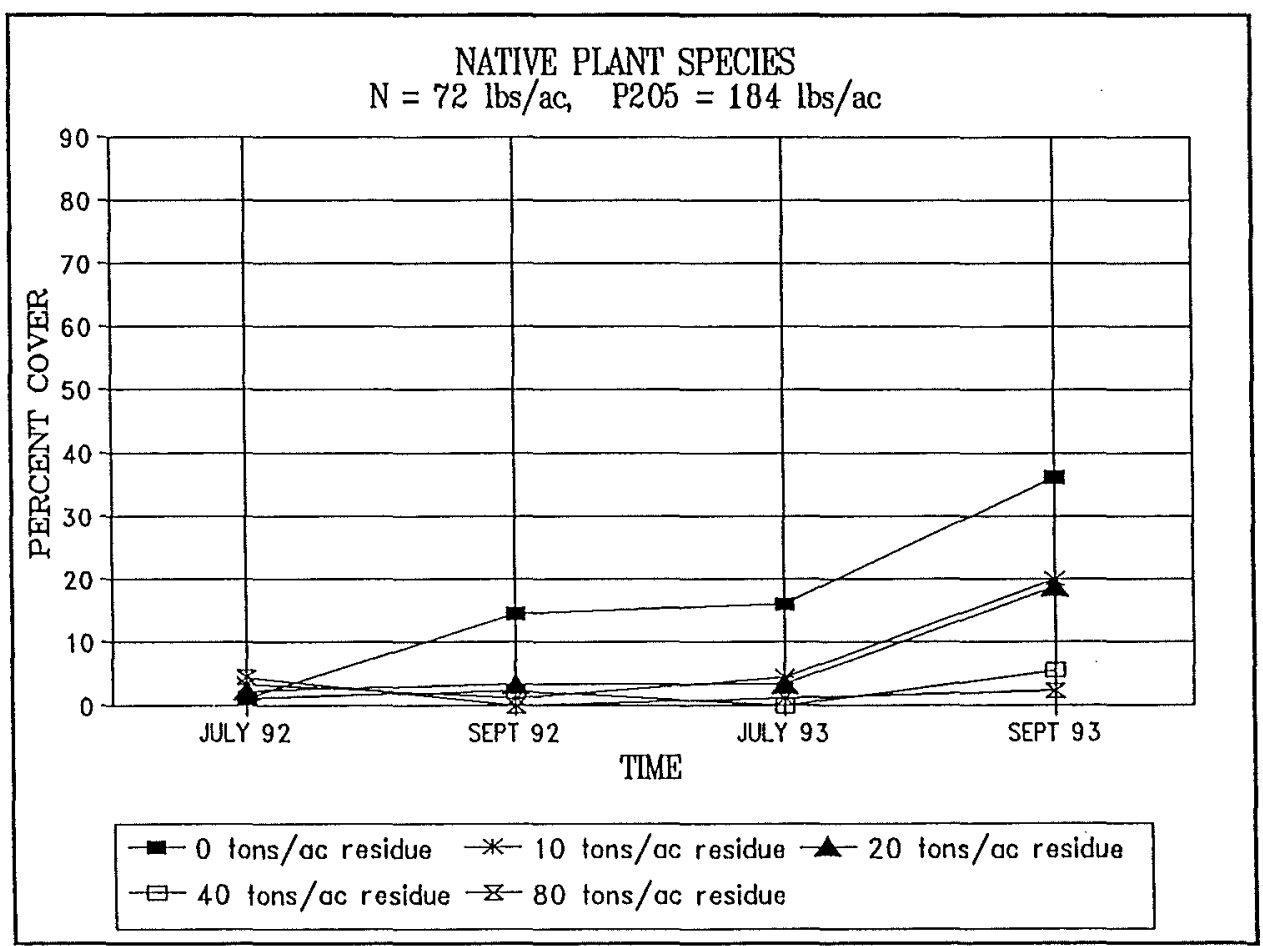

Figure 30.--The mean percent cover, over time, for native species treated with de-inking residue and commercial fertilizer at $\mathrm{N}=72$ and $\mathrm{P}_{2} \mathrm{O}_{5}=184 \mathrm{lb} / \mathrm{acre}$. 


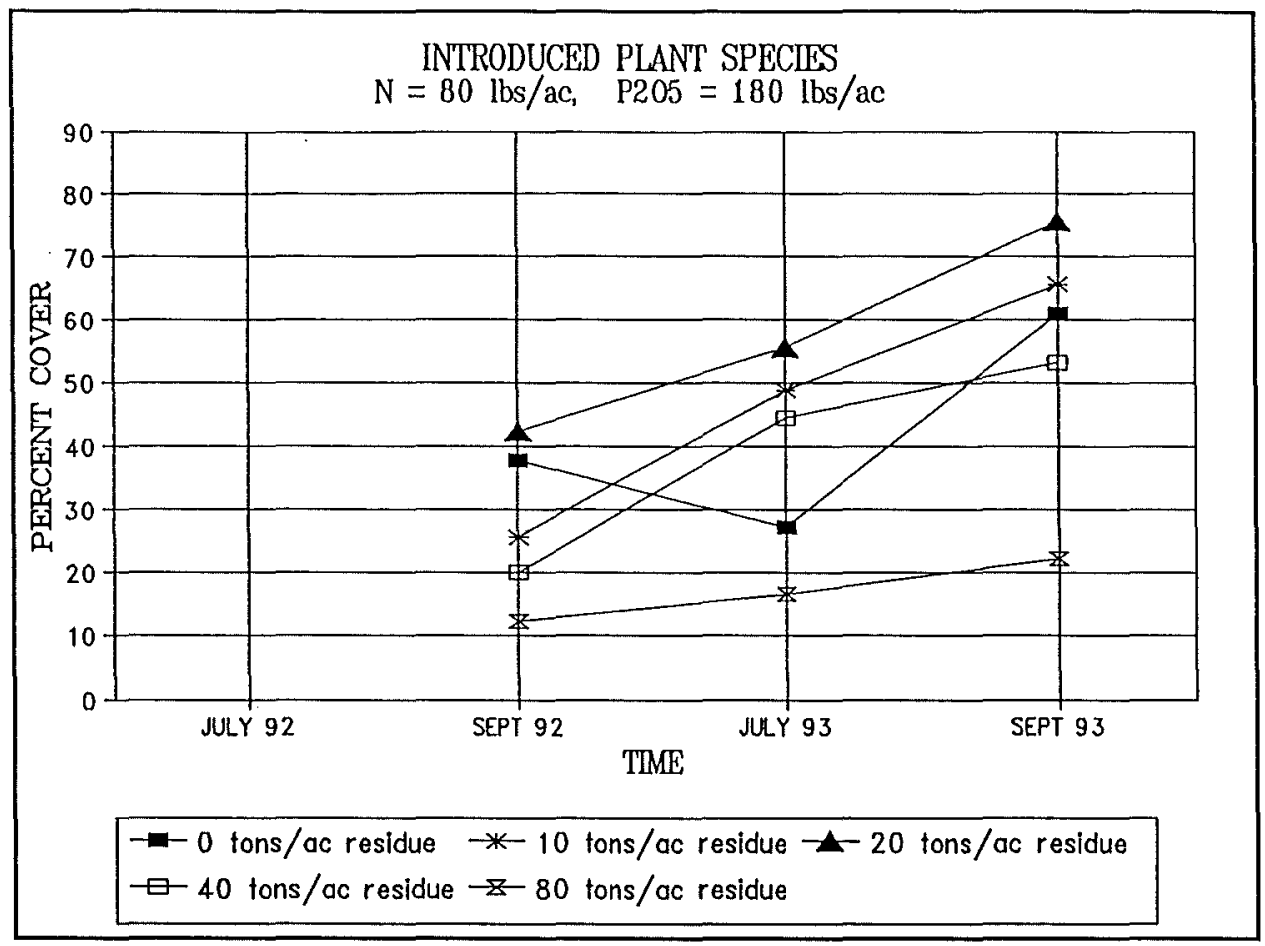

Figure 31.--The mean percent cover, over time, for introduced species treated with de-inking residue and commercial fertilizer at $\mathrm{N}=80 \mathrm{lb} /$ acre and $\mathrm{P}_{2} \mathrm{O}_{5}=180$ lb/acre.

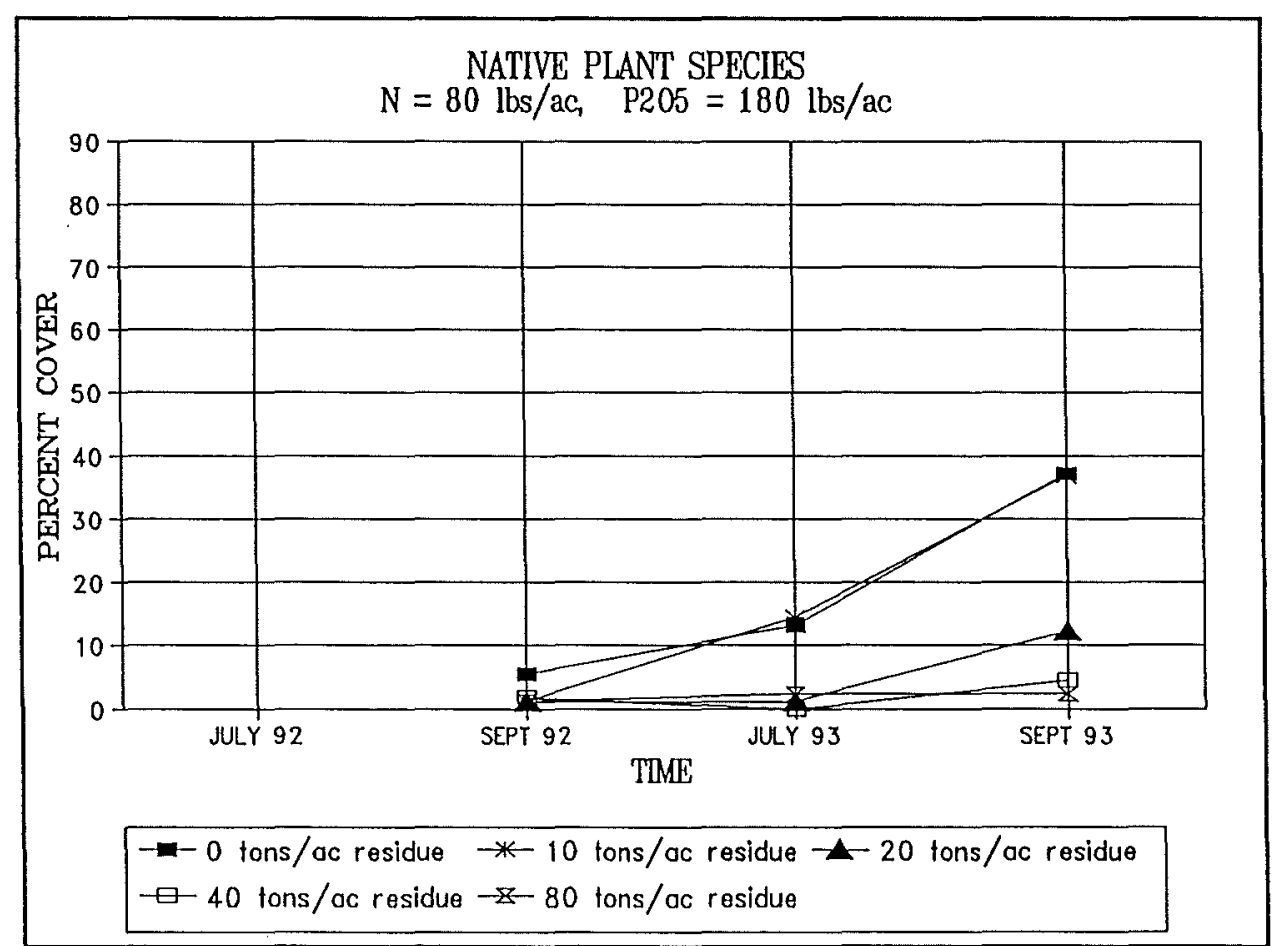

Figure 32.--The mean percent cover, over time, for native species treated with de-inking residue and commercial fertilizer at $\mathrm{N}=80 \mathrm{lb} / \mathrm{acre}$ and $\mathrm{P}_{2} \mathrm{O}_{5}=180$ lb/acre. 


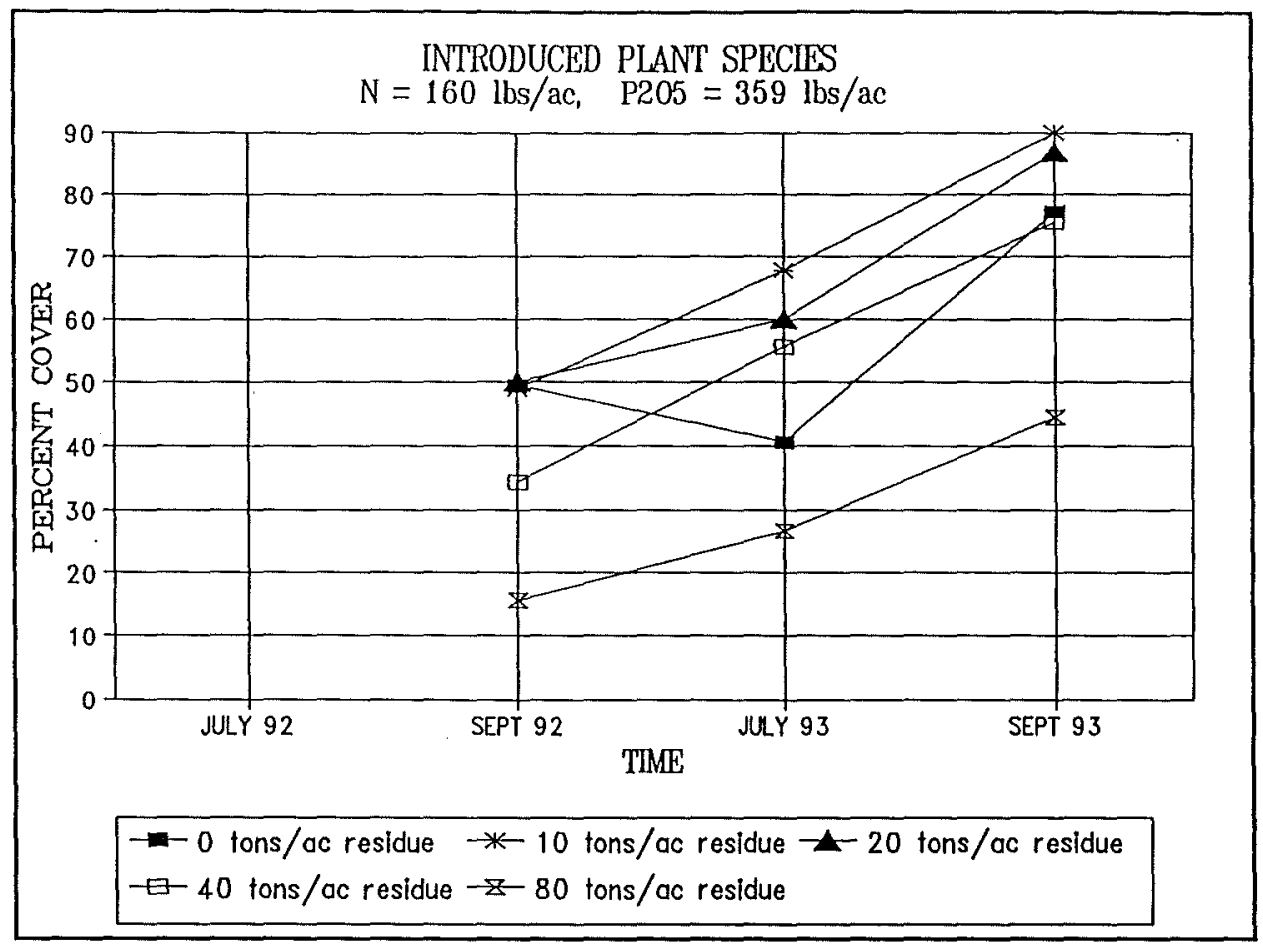

Figure 33.--The mean percent cover, over time, for introduced species treated with de-inking residue and commercial fertilizer at $\mathrm{N}=160 \mathrm{lb} / \mathrm{acre}$ and $\mathrm{P}_{2} \mathrm{O}_{5}=359$ lb/acre.

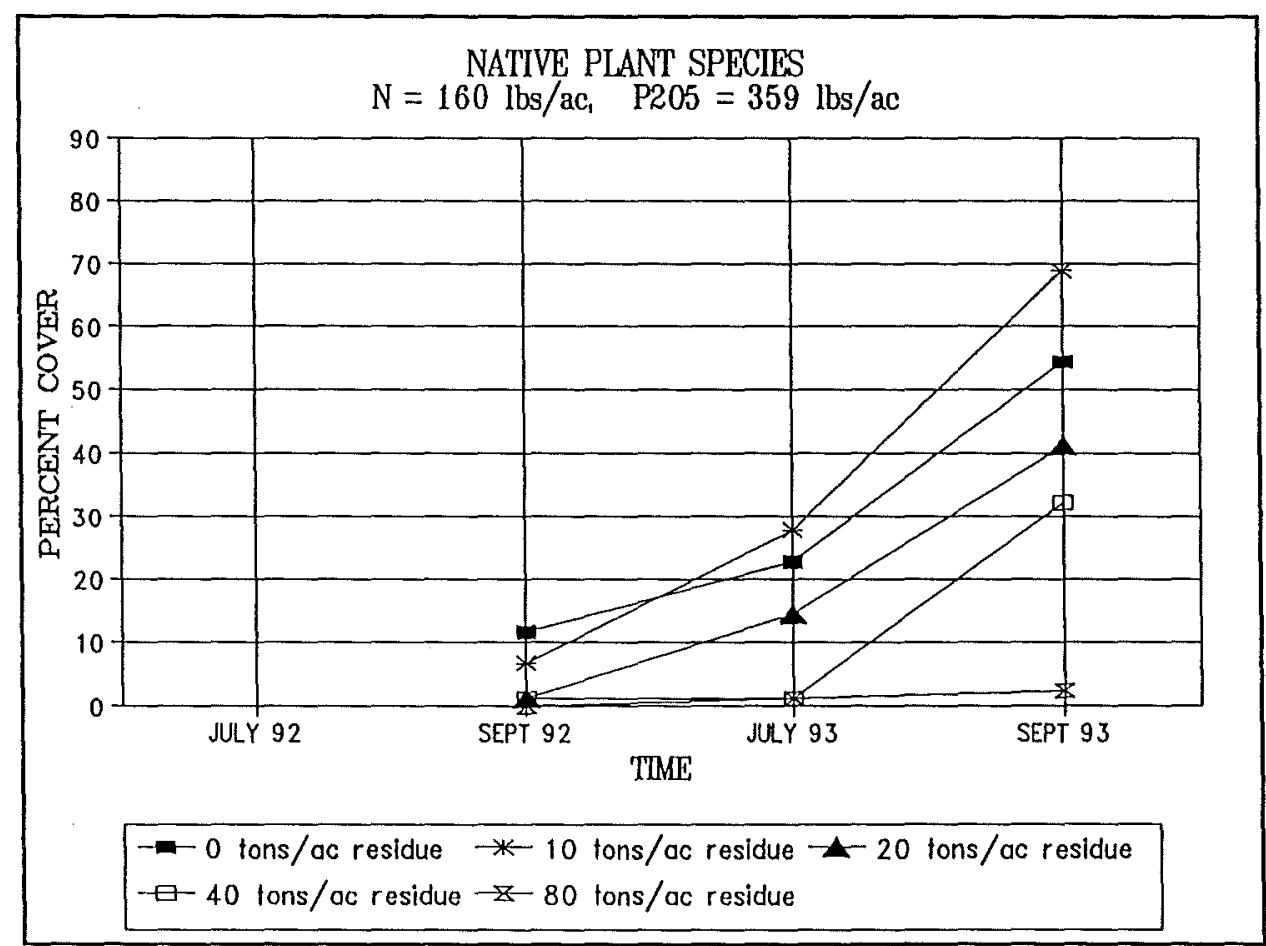

Figure 34.--The mean percent cover, over time, for native species treated with de-inking residue and commercial fertilizer at $\mathrm{N}=160 \mathrm{lb} / \mathrm{acre}$ and $\mathrm{P}_{2} \mathrm{O}_{5}=359$ lb/acre. 


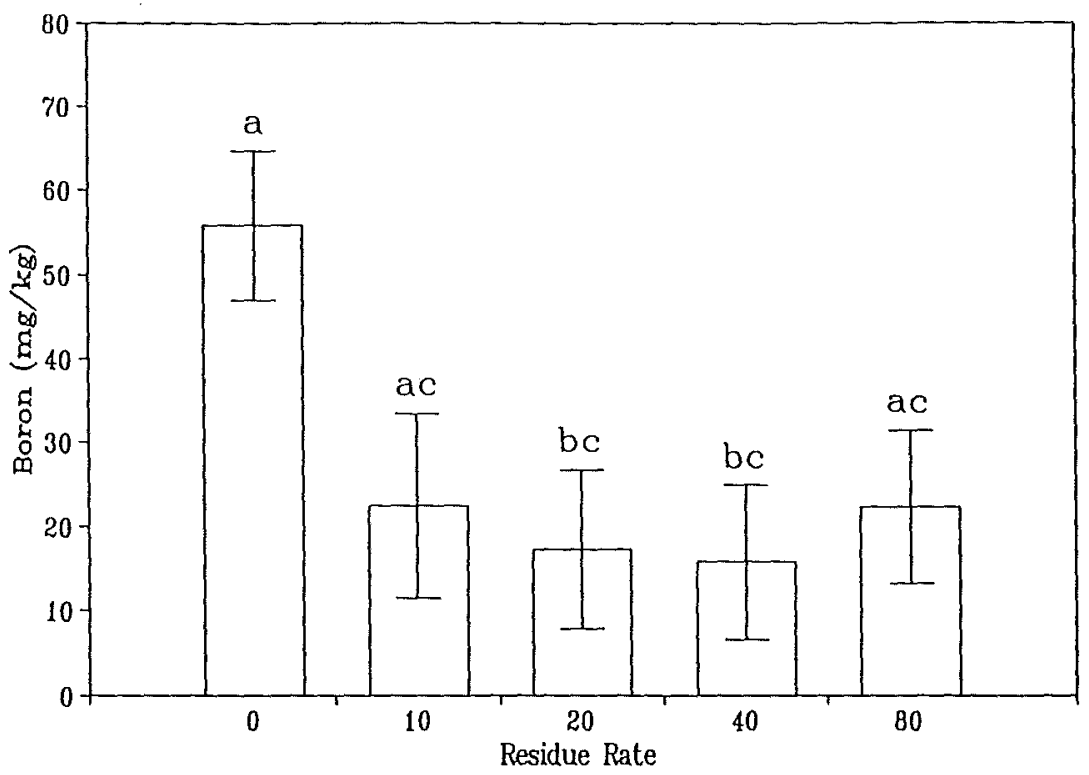

Figure 35.--The mean level of boron in alfalfa (with standard error bars), across fertilizer treatments by residue rate. Means with the same letter above the error bar are not significantly different.

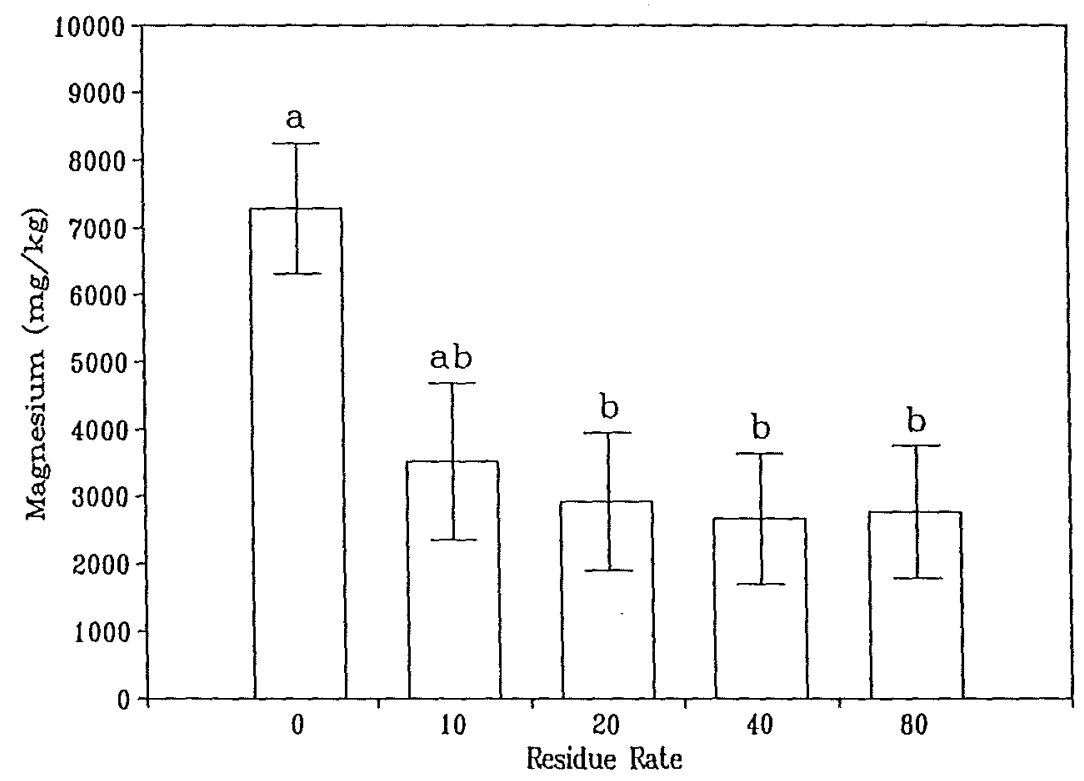

Figure 36.--The mean level of magnesium in alfalfa (with standard error bars), across fertilizer treatments by residue rate. Means with the same letter above the error bar are not significantly different. 


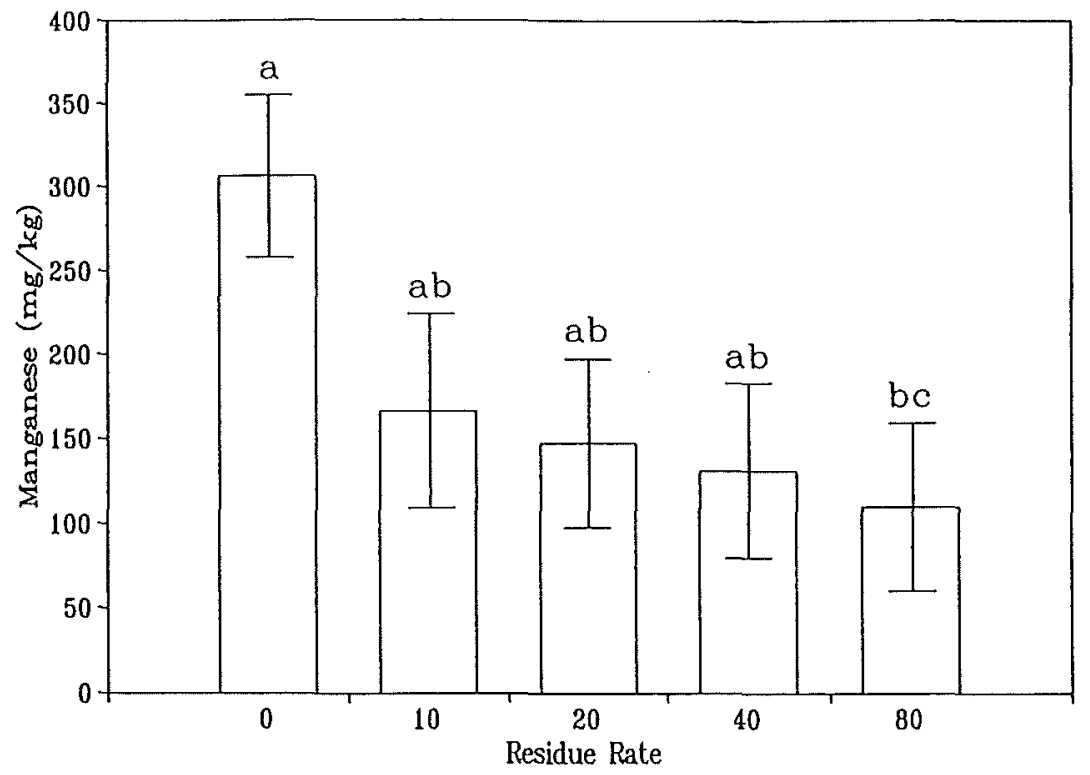

Figure 37.--The mean level of manganese in alfalfa (with standard error bars), across fertilizer treatments by residue rate. Means with the same letter above the error bar are not significantly different. 


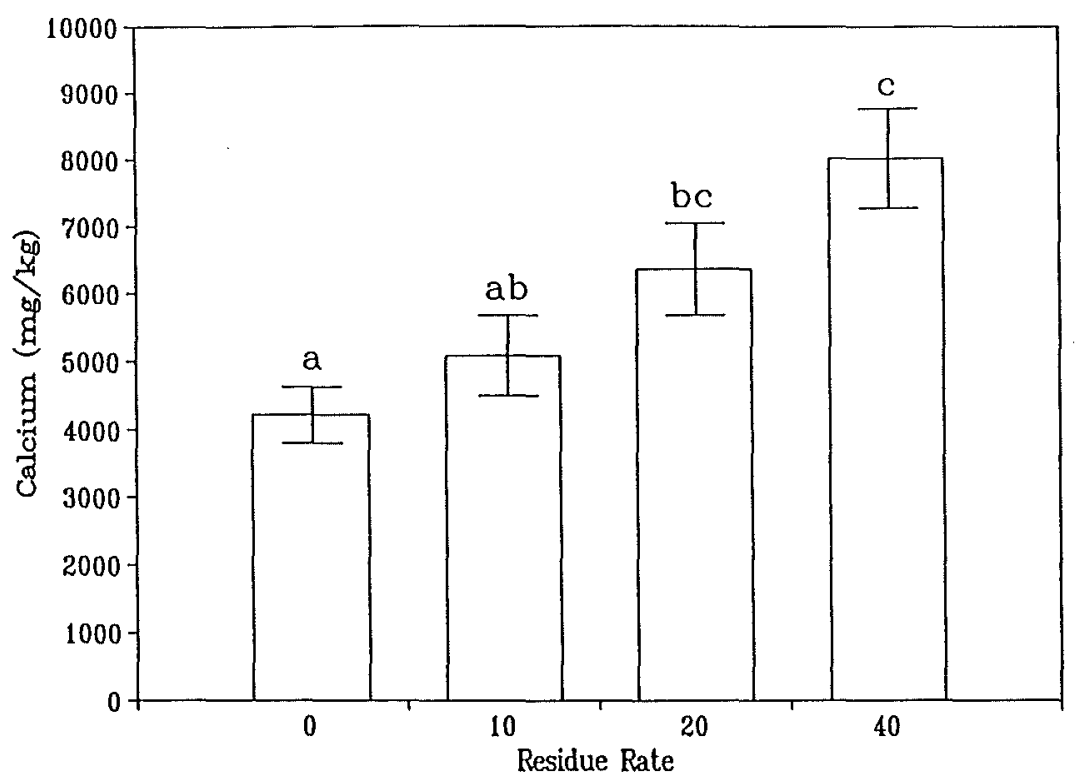

Figure 38.--The mean level of calcium in bluestem (with standard error bars), across fertilizer treatments by residue rate. Means with the same letter above the error bar are not significantly different.

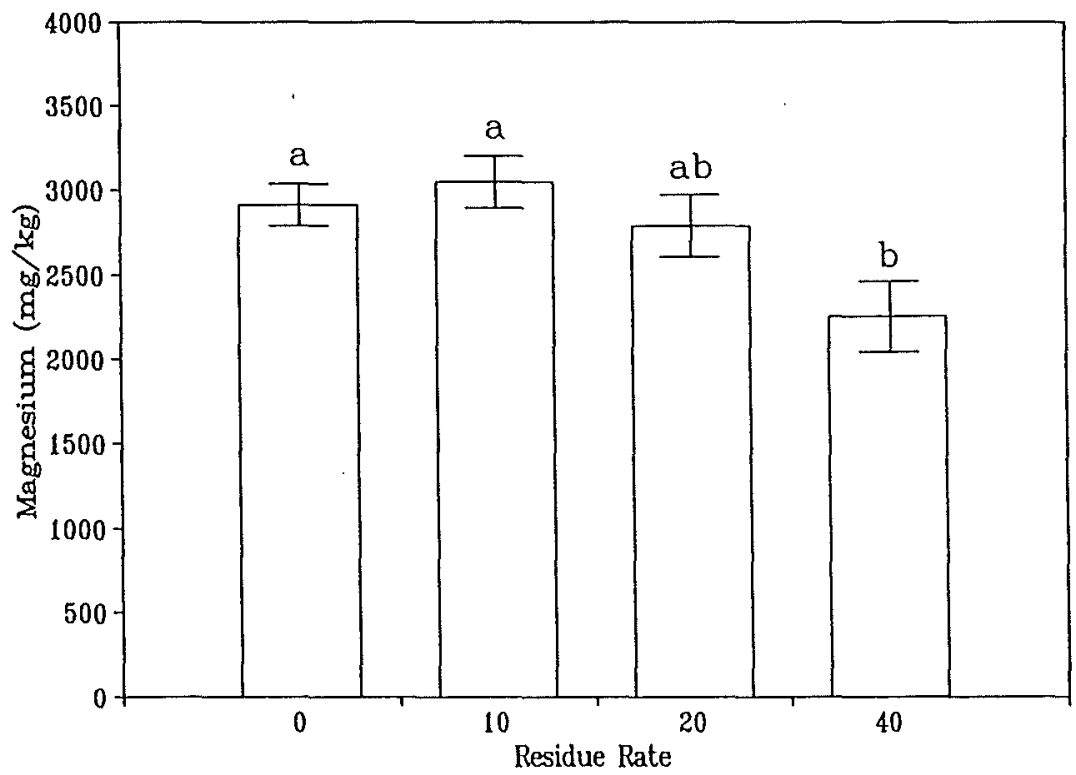

Figure 39.--The mean level of magnesium in bluestem (with standard error bars), across fertilizer treatments by residue rate. Means with the same letter above the error bar are not significantly different. 


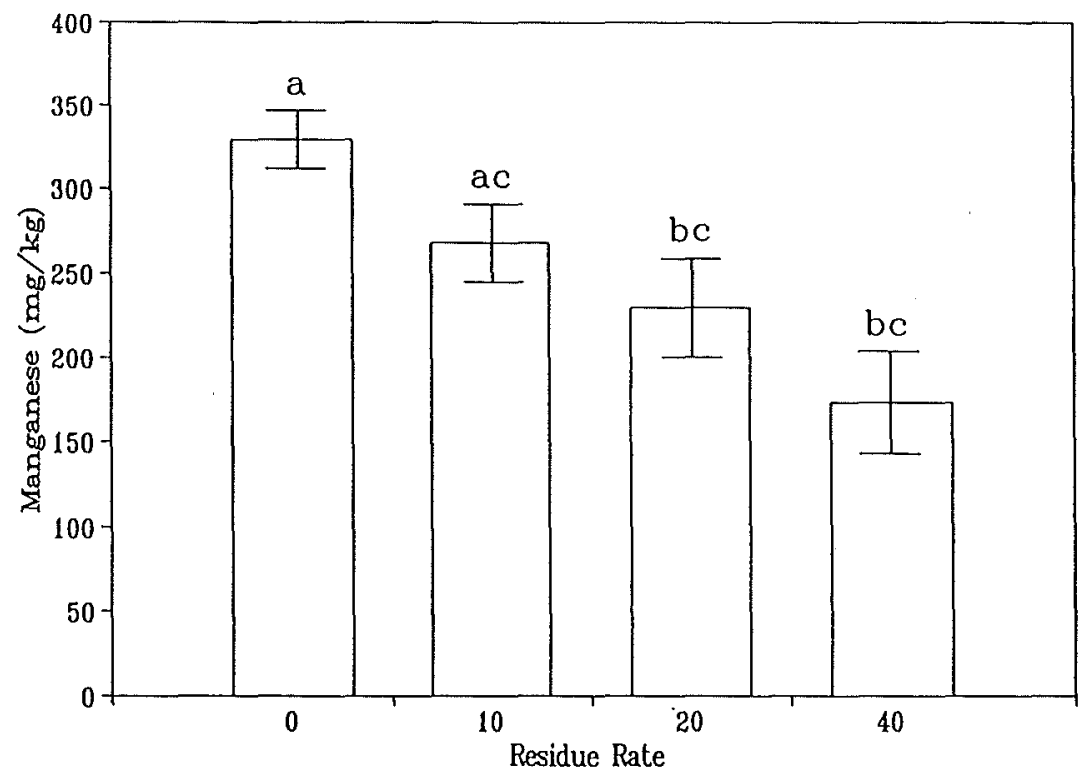

Figure 40.--The mean level of manganese in bluestem (with standard error bars), across fertilizer treatments by residue rate. Means with the same letter above the error bar are not significantly different.

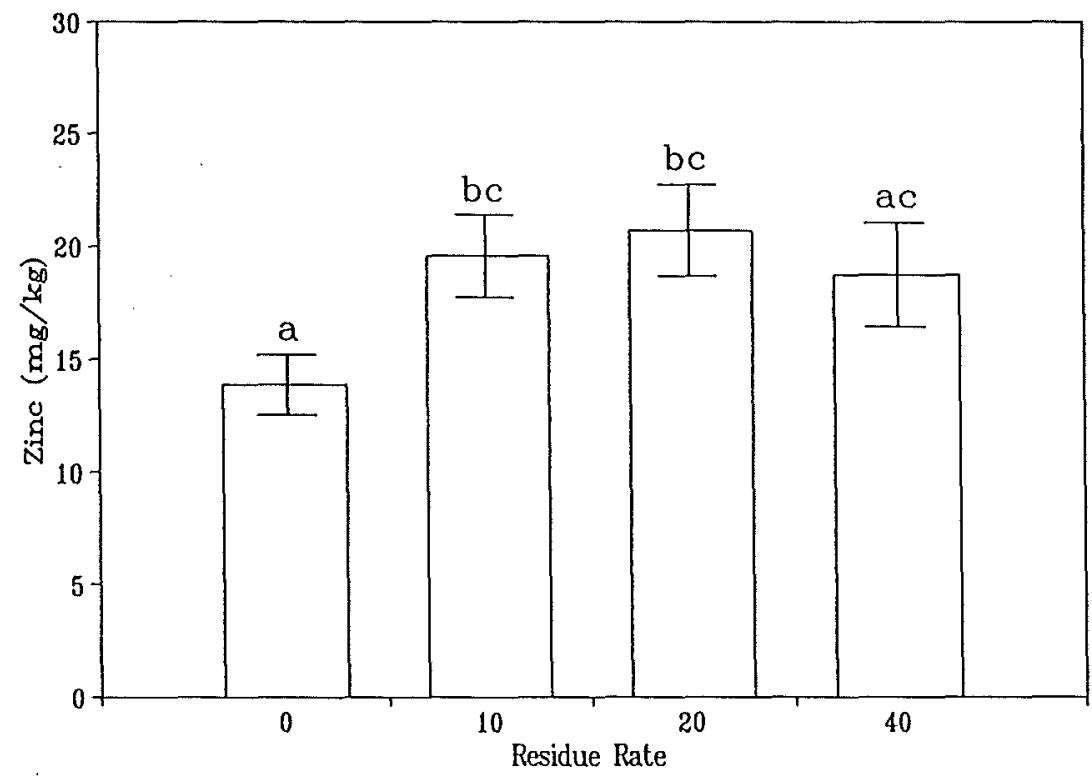

Figure 41.--The mean level of zinc in bluestem (with standard error bars), across fertilizer treatments by residue rate. Means with the same letter above the error bar are not significantly different. 


\section{APPENDIX A}

The chemical analyses for coarse tailings/residue mixtures sampled four times in 1992 through 1993 after plot establishment. 
A-1.--Nutrient analysis of coarse tailings/residue mixture, spring 1992.

\begin{tabular}{|c|c|c|c|c|c|c|c|c|c|c|c|c|c|c|c|c|c|c|c|c|c|c|c|c|c|c|}
\hline 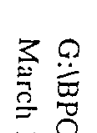 & $\begin{array}{l}\text { Pint } \\
\text { Type }\end{array}$ & $\begin{array}{l}\mathrm{N} \\
\mathrm{db} / \\
\mathrm{ac}\end{array}$ & $\begin{array}{l}\text { P205 } \\
\text { Ib/ } \\
\text { ac }\end{array}$ & $\begin{array}{l}\text { Res } \\
\mathrm{En} / \\
\mathrm{ac}\end{array}$ & $\begin{array}{l}\text { Mo1s } \\
t\end{array}$ & $\begin{array}{l}\mathrm{NO} \\
-\mathrm{N} \\
\mathrm{pPm}\end{array}$ & $\begin{array}{l}\mathrm{NEA} \\
-\mathrm{N} \\
\mathrm{ppm}\end{array}$ & $\begin{array}{l}\text { org } \\
\text { Mat } \\
t\end{array}$ & $\mathrm{PH}$ & $\begin{array}{l}\mathrm{ECl}: 1 \\
\text { minhos } \\
/ \mathrm{ctn}\end{array}$ & $\begin{array}{l}\mathrm{so4} \\
-\mathrm{s} \\
\mathrm{ppm}\end{array}$ & $\begin{array}{l}\text { Ols } \\
-P \\
\text { ppm }\end{array}$ & $\begin{array}{l}\mathrm{CEC} \\
\mathrm{meq} / \\
100 \mathrm{~g}\end{array}$ & $\begin{array}{l}\mathrm{Cl} \\
\mathrm{ppm}\end{array}$ & $\begin{array}{l}\text { TOt } \\
N \\
t\end{array}$ & $\begin{array}{l}\text { TOC } \\
z\end{array}$ & $\begin{array}{l}\mathrm{Fe} \\
\mathrm{ppm}\end{array}$ & $\begin{array}{l}\mathrm{Mn} \\
\mathrm{ppm}\end{array}$ & $\begin{array}{l}\mathrm{zn} \\
\mathrm{ppm}\end{array}$ & $\begin{array}{l}\mathrm{Cu} \\
\mathrm{ppm}\end{array}$ & $\begin{array}{l}\mathrm{Pb} \\
\mathrm{Ppm}\end{array}$ & $\mathrm{N1}$ & $\begin{array}{l}\mathrm{cd} \\
\mathrm{ppm}\end{array}$ & $\begin{array}{l}\mathrm{cr} \\
\mathrm{ppm}\end{array}$ & $\begin{array}{l}\mathrm{P} \\
\mathrm{ppm}\end{array}$ & $\begin{array}{l}\mathrm{C}: \mathrm{N} \\
\mathrm{Rat}\end{array}$ \\
\hline & $N$ & 0 & 0 & 0 & 1.0 & 5.9 & 1.5 & 1.0 & 8.5 & 0.3 & 2 & 1 & 2.1 & 8.2 & 0.01 & 1.06 & 58.47 & 16.58 & 0.09 & 0.09 & 0.36 & 0.09 & 0.02 & 0.02 & 257 & 106 \\
\hline & s & 0 & 0 & 10 & 2.1 & 2.4 & 3.5 & 1.1 & 8.6 & 0.3 & 2 & 2 & 2.0 & 15.0 & 0.01 & 0.74 & 52.37 & 14.35 & 0.18 & 0.09 & 0.22 & 0.15 & 0.02 & 0.02 & 323 & 74 \\
\hline$=g$ & $N$ & 0 & 0 & 20 & 5.9 & 0.1 & 0.1 & 1.7 & 8.7 & 0.3 & 3 & 1 & 2.1 & 18.1 & 0.02 & 1.21 & 56.26 & 14.08 & 0.16 & 0.08 & 0.22 & 0.12 & 0.06 & 0.02 & 390 & 57 \\
\hline & $\mathrm{N}$ & 0 & 0 & 40 & 8.2 & 0.1 & 0.2 & 1.3 & 8.7 & 0.2 & 2 & 1 & 1.9 & 9.6 & 0.02 & 0.75 & 47.25 & 16.86 & 0.24 & 0.17 & 0.25 & 0.13 & 0.02 & 0.02 & 235 & 75 \\
\hline$\widetilde{3}$ & $N$ & 0 & 0 & 80 & 40.2 & 0.1 & 0.7 & 2.9 & 8.7 & 0.5 & 6 & 2 & 2.1 & 27.9 & 0.02 & 1.87 & 28.19 & 6.58 & 1.42 & 0.22 & 0.41 & 0.15 & 0.02 & 0.02 & 221 & 94 \\
\hline 5 & $N$ & 0 & 0 & 0 & 1.0 & 10.4 & 0.2 & 1.2 & 8.4 & 0.7 & 1 & 1 & 2.0 & 21.5 & 0.01 & 0.97 & 59.02 & 15.94 & 0.11 & 0.05 & 0.30 & 0.09 & 0.02 & 0.02 & 210 & 97 \\
\hline 0 & $N$ & 36 & 92 & 0 & 0.9 & 7.4 & 16.0 & 0.9 & 8.4 & 0.5 & 3 & 24 & 2.2 & 23.3 & 0.01 & 0.86 & 45.68 & 10.55 & 0.20 & 0.13 & 0.25 & 0.10 & 0.02 & 0.02 & 245 & 86 \\
\hline$f$ & * & 36 & 92 & 10 & 3.6 & 0.1 & 1.7 & 0.8 & 8.2 & 0.3 & 2 & 28 & 1.9 & 18.6 & 0.01 & 0.67 & 38.21 & 9.76 & 0.25 & 0.13 & 0.76 & 0.13 & 0.03 & 0.02 & 265 & 57 \\
\hline$\Xi$ & $N$ & 35 & 92 & 20 & 4.2 & 0.1 & 3.5 & 1.0 & 8.2 & 0.3 & 1 & 20 & 2.0 & 22.5 & 0.01 & 1.06 & 39.41 & 11.36 & 0.30 & 0.15 & 0.46 & 0.09 & 0.02 & 0.02 & 206 & 106 \\
\hline & $N$ & 36 & 92 & 40 & 12.6 & 0.1 & 1.0 & 1.5 & 8.4 & 0.2 & 1 & 10 & 2.0 & 13.7 & 0.01 & 1.39 & 40.74 & 13.73 & 0.24 & 0.11 & 0.22 & 0.14 & 0.02 & 0.02 & 253 & 139 \\
\hline & $\mathrm{N}$ & 35 & 92 & 80 & 41.2 & 0.1 & 0.5 & 1.6 & 8.5 & 0.3 & 2 & 8 & 2.1 & 49.3 & 0.01 & 1.37 & 33.78 & 8.38 & 1.92 & 0.11 & 0.47 & 0.26 & 0.02 & 0.02 & 242 & 237 \\
\hline & $\mathrm{N}$ & 36 & 92 & 0 & 1.4 & 15.3 & 3.3 & 0.9 & 7.9 & 0.4 & 3 & 25 & 2.0 & 17.0 & 0.01 & 0.85 & 40.79 & 11.01 & 0.20 & 0.07 & 0.38 & 0.19 & 0.02 & 0.02 & 224 & 85 \\
\hline & $N$ & 72 & 184 & 0 & 1.4 & 8.2 & 17.1 & 1.0 & 8.2 & 0.4 & 1 & 31 & 1.9 & 14.0 & 0.01 & 1.04 & 47.25 & 15.59 & 0.07 & 0.12 & 0.38 & 0.26 & 0.02 & 0.02 & 263 & 104 \\
\hline & $N$ & 72 & 284 & 10 & 2.4 & 1.2 & 5.2 & 1.3 & 7.9 & 0.3 & 2 & 36 & 2.1 & 20.4 & 0.02 & 0.97 & 37.51 & 11.56 & 0.27 & 0.09 & 0.52 & 0.12 & 0.02 & 0.02 & 275 & 49 \\
\hline & $N$ & 72 & 184 & 20 & 3.2 & 1.2 & 2.6 & 1.2 & 7.7 & 0.3 & 1 & 30 & 2.3 & 15.6 & 0.02 & 0.92 & 39.53 & 10.52 & 0.18 & 0.12 & 0.22 & 0.19 & 0.02 & 0.02 & 293 & 46 \\
\hline & $\mathrm{N}$ & 72 & 184 & 40 & 17.5 & 0.2 & 0.9 & 1.0 & 7.8 & 0.3 & 3 & 37 & 2.0 & 21.4 & 0.02 & 2.13 & 29.80 & 7.68 & 0.55 & 0.14 & 0.22 & 0.09 & 0.02 & 0.02 & 273 & 57 \\
\hline & $N$ & 72 & 184 & 80 & 30.2 & 0.1 & 0.3 & 3.7 & 8.2 & 0.4 & 6 & 17 & 2.1 & 27.4 & 0.02 & 2.29 & 32.46 & 8.01 & 1.12 & 0.26 & 0.22 & 0.11 & 0.02 & 0.02 & 277 & 115 \\
\hline & $N$ & 72 & 284 & 0 & 2.2 & 16.5 & 3.6 & 1.0 & 8.1 & 0.4 & 2 & 25 & 2.2 & 17.3 & 0.01 & 0.99 & 49.00, & 11.60 & 0.11 & 0.17 & 0.33 & 0.09 & 0.02 & 0.02 & 254 & 99 \\
\hline & $I$ & 0 & 0 & 0 & 1.0 & 3.2 & 2.2 & 1.1 & 8.6 & 0.3 & 1 & 2 & 2.0 & 16.5 & 0.02 & 1.00 & 61.29 & 17.58 & 0.05 & 0.22 & 0.22 & 0.21 & 0.02 & 0.02 & 242 & 100 \\
\hline & $I$ & 0 & 0 & 10 & 3.3 & 0.1 & 0.3 & 1.1 & 8.5 & 0.3 & 2 & 2 & 1.8 & 17.5 & 0.01 & 0.99 & 52.64 & 15.01 & 0.13 & 0.09 & 0.57 & 0.09 & 0.02 & 0.02 & 290 & 99 \\
\hline & I & 0 & 0 & 20 & 3.2 & 0.1 & 1.3 & 1.2 & 8.6 & 0.2 & 1 & 1 & $1 . .8$ & 11.1 & 0.01 & 1.15 & 54.34 & 17.33 & 0.13 & 0.12 & 0.90 & 0.09 & 0.02 & 0.02 & 230 & 115 \\
\hline & I & 0 & 0 & 40 & 12.4 & 0.2 & 0.1 & 1.2 & 8.7 & 0.2 & 2 & 1 & 2.0 & 23.6 & 0.01 & 1.10 & 38.89 & 9.19 & 0.30 & 0.07 & 0.75 & 0.09 & 0.02 & 0.02 & 225 & 110 \\
\hline & I & 0 & 0 & 80 & 32.9 & 0.3 & 0.1 & 1.3 & 8.6 & 0.3 & 2 & 3 & 2.0 & 23.2 & 0.02 & 2.60 & 30.93 & 7.75 & 0.70 & 0.25 & 0.38 & 0.09 & 0.02 & 0.02 & 238 & 80 \\
\hline & I & 0 & 0 & 0 & 1.1 & 12.8 & 0.9 & 1.2 & 8.3 & 0.4 & 2 & 2 & 1.9 & 16.1 & 0.01 & 1.13 & 55.67 & 15.47 & 0.14 & 0.13 & 0.90 & 0.28 & 0.02 & 0.04 & 177 & 213 \\
\hline & : & 36 & 92 & 0 & 1.4 & 17.0 & 4.1 & 1.0 & 7.8 & 0.6 & 3 & 27 & 2.1 & 26.6 & 0.01 & 1.09 & 11.94 & 12.47 & 0.06 & 0.12 & 0.22 & 0.24 & 0.02 & 0.02 & 301 & 109 \\
\hline & $I$ & 36 & 92 & 10 & 2.3 & 3.2 & 12.8 & 0.9 & 7.8 & 0.3 & 1 & 43 & 2.1 & 17.8 & 0.02 & 1.14 & 36.55 & 21.10 & 0.14 & 0.07 & 0.28 & 0.19 & 0.02 & 0.02 & 298 & $5 ?$ \\
\hline & I & 36 & 92 & 20 & 6.8 & 0.1 & 4.8 & 1.0 & 8.2 & 0.2 & 2 & 21 & 1.9 & 14.8 & 0.02 & 1.14 & 36.86 & 11.41 & 0.38 & 0.10 & 0.22 & 0.16 & 0.02 & 0.02 & 224 & 57 \\
\hline & I & 36 & 92 & 40 & 8.9 & 0.1 & 0.8 & 1.1 & 8.1 & 0.2 & 1 & 21 & 2.0 & 11.9 & 0.01 & 1.22 & 34.12 & 9.68 & 1.85 & 0.11 & 0.24 & 0.24 & 0.02 & 0.02 & 249 & 122 \\
\hline & $I$ & 36 & 92 & 80 & 35.7 & 0.2 & 0.3 & 1.7 & 8.2 & 0.2 & 2 & 27 & 1.9 & 22.8 & 0.02 & 1.80 & 31.39 & 7.64 & 0.90 & 0.17 & 0.28 & 0.09 & 0.02 & 0.02 & 288 & 90 \\
\hline & I & 36 & 92 & 0 & 1.2 & 19.0 & 9.7 & 1.1 & 8.0 & 0.4 & 1 & 23 & 1.9 & 12.2 & 0.02 & 1.12 & 45.93 & 11.85 & 0.20 & 0.09 & 0.23 & 0.25 & 0.02 & 0.03 & 251 & 55 \\
\hline & \pm & 72 & 284 & 0 & 1.2 & 21.6 & 13.8 & 1.0 & 8.0 & 0.5 & 3 & 30 & 1.9 & 21.0 & 0.02 & 0.82 & 44.52 & 12.27 & 0.13 & 0.10 & 0.22 & 0.23 & 0.02 & 0.02 & 252 & 42 \\
\hline & z & 72 & 184 & 10 & 3.4 & 0.5 & 1.0 & 1.2 & 7.9 & 0.3 & 2 & 28 & 1.8 & 24.3 & 0.02 & 0.78 & 37.22 & 9.93 & 0.14 & 0.05 & 0.22 & 0.17 & 0.02 & 0.02 & 317 & 39 \\
\hline & $I$ & 72 & 284 & 20 & 6.9 & 0.1 & 3.3 & 1.0 & 8.0 & 0.2 & 1 & 24 & 2.0 & 11.9 & 0.02 & 0.91 & 36.61 & 21.02 & 0.22 & 0.07 & 0.22 & 0.22 & 0.02 & 0.03 & 251 & 46 \\
\hline & I & 72 & 184 & 40 & 9.7 & 0.1 & 0.8 & 1.2 & 7.8 & 0.3 & 3 & 29 & 1.9 & 19.9 & 0.02 & 1.09 & 33.97 & 10.20 & 0.39 & 0.11 & 0.22 & 0.23 & 0.02 & 0.05 & 221 & 55 \\
\hline & \pm & 72 & 184 & 80 & 26.0 & 0.2 & 1.1 & 1.5 & 7.8 & 0.4 & 3 & 40 & 2.1 & 21.7 & 0.02 & 2.40 & 32.08 & 8.22 & 0.57 & 0.14 & 0.23 & 0.21 & 0.02 & 0.04 & 283 & 70 \\
\hline & $I$ & 72 & 184 & 0 & 0.9 & 8.2 & 28.6 & 0.8 & 7.9 & 0.5 & 3 & 48 & 2.0 & 19.9 & 0.02 & 1.23 & 39.48 & 10.29 & 0.12 & 0.09 & 0.22 & 0.28 & 0.02 & 0.05 & 342 & 62 \\
\hline
\end{tabular}


A-2.--Continued

\begin{tabular}{|c|c|c|c|c|c|c|c|c|c|c|c|c|c|c|c|c|c|c|c|c|c|c|c|c|c|c|}
\hline \multirow{11}{*}{ 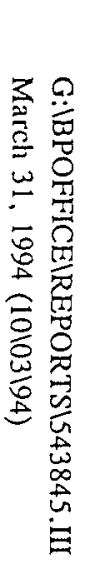 } & $\begin{array}{l}\text { Plnt } \\
\text { Type }\end{array}$ & $\begin{array}{l}\mathrm{N} \\
\mathrm{Ib} / \\
\mathrm{ac}\end{array}$ & $\begin{array}{l}8205 \\
10 / \\
a c\end{array}$ & $\begin{array}{l}\text { Res } \\
\mathrm{en} / \\
\mathrm{ac}\end{array}$ & $\begin{array}{l}\text { Mols } \\
t\end{array}$ & $\begin{array}{l}\mathrm{NO3} \\
-\mathrm{N} \\
\mathrm{ppm}\end{array}$ & $\begin{array}{l}\mathrm{NHA} \\
-\mathrm{N} \\
\mathrm{ppm}\end{array}$ & $\begin{array}{l}\text { Org } \\
\text { Mat } \\
t\end{array}$ & $\mathrm{pH}$ & $\begin{array}{l}\mathrm{EC1}: 1 \\
\text { mmhos } \\
/ \mathrm{cm}\end{array}$ & $\begin{array}{l}\text { so4 } \\
-\mathrm{s} \\
\mathrm{ppm}\end{array}$ & $\begin{array}{l}018 \\
-P \\
\text { ppm }\end{array}$ & $\begin{array}{l}C B C \\
\text { meq/ } \\
100 \mathrm{~g}\end{array}$ & $\begin{array}{l}\mathrm{Cl} \\
\mathrm{ppm}\end{array}$ & $\begin{array}{l}\text { Tot } \\
\text { N } \\
t\end{array}$ & $\begin{array}{l}\text { TOC } \\
:\end{array}$ & $\begin{array}{l}\mathrm{Fe} \\
\mathrm{ppm}\end{array}$ & $\begin{array}{l}\mathrm{Mn} \\
\mathrm{ppm}\end{array}$ & $\begin{array}{l}\mathrm{2n} \\
\mathrm{ppm}\end{array}$ & $\begin{array}{l}\text { cu } \\
\text { ppm }\end{array}$ & $\begin{array}{l}\mathrm{Pb} \\
\mathrm{PPm}\end{array}$ & $\begin{array}{l}\mathrm{N} 1 \\
\mathrm{ppm}\end{array}$ & $\begin{array}{l}\mathrm{Cd} \\
\mathrm{ppm}\end{array}$ & $\begin{array}{l}c r \\
\mathrm{ppm}\end{array}$ & $\begin{array}{l}\mathrm{P} \\
\mathrm{ppm}\end{array}$ & $\begin{array}{l}C: N \\
\text { Rat }\end{array}$ \\
\hline & $\mathrm{s}$ & 0 & 0 & 0 & 1.8 & 0.4 & 0.2 & 0.7 & 8.2 & 0.1 & 1 & 3 & 1.9 & 3.4 & 0.01 & 1.10 & 66.39 & 17.20 & 0.14 & 0.14 & 0.27 & 0.09 & 0.02 & 0.02 & 231 & 220 \\
\hline & $N$ & 0 & 0 & 10 & 2.3 & 0.4 & 0.1 & 0.8 & 8.5 & 0.1 & 2 & 2 & 1.8 & 0.7 & 0.01 & 1.15 & 53.79 & 12.87 & 0.25 & 0.13 & 0.22 & 0.09 & 0.02 & 0.02 & 179 & 192 \\
\hline & $\mathrm{N}$ & 0 & 0 & 20 & 3.2 & 0.4 & 0.1 & 0.9 & 8.5 & 0.1 & 1 & 2 & 1.7 & 0.7 & 0.01 & 1.13 & 47.10 & 11.05 & 0.22 & 0.13 & 0.22 & 0.09 & 0.02 & 0.02 & 137 & 288 \\
\hline & $\mathrm{N}$ & 0 & 0 & 40 & 5.7 & 0.5 & 0.1 & 1.2 & 8.4 & 0.1 & 1 & 2 & 1.5 & 7.1 & 0.01 & 1.02 & 44.76 & 12.71 & 0.34 & 0.15 & 0.22 & 0.17 & 0.03 & 0.02 & 166 & 246 \\
\hline & $\mathrm{N}$ & 0 & 0 & 80 & 8.6 & 2.6 & 0.6 & 1.6 & 8.2 & 0.2 & 1 & 7 & 2.1 & 12.7 & 0.01 & 6.71 & 43.51 & 7.72 & 2.13 & 1.13 & 0.43 & 0.28 & 0.04 & 0.04 & 280 & 526 \\
\hline & $\mathrm{N}$ & 0 & 0 & 0 & 1.8 & 0.4 & 0.1 & 0.9 & 8.4 & 0.1 & 2 & 2 & 1.7 & 0.1 & 0.00 & 2.08 & 53.52 & 12.54 & 0.61 & 0.15 & 0.62 & 0.13 & 0.04 & 0.03 & 120 & 360 \\
\hline & $\mathrm{N}$ & 80 & 180 & 0 & 1.7 & 0.4 & 0.1 & 0.9 & 8.3 & 0.1 & 1 & 10 & 1.8 & 0.6 & 0.00 & 0.98 & 48.12 & 10.27 & 1.07 & 0.15 & 0.22 & 0.21 & 0.04 & 0.02 & 182 & 492 \\
\hline & $\mathrm{N}$ & 80 & 180 & 10 & 2.6 & 0.4 & 0.1 & 1.0 & 8.4 & 0.2 & 1 & 14 & 1.8 & 6.6 & 0.00 & 1.21 & 42.86 & 8.87 & 0.26 & 0.13 & 0.22 & 0.09 & 0.02 & 0.02 & 151 & 370 \\
\hline & $N$ & 80 & 180 & 20 & 3.8 & 0.4 & 1.0 & 0.9 & 8.0 & 0.1 & 1 & 39 & 2.9 & 2.0 & 0.01 & 2.14 & 36.24 & 8.57 & 0.39 & 0.17 & 0.22 & 0.09 & 0.02 & 0.02 & 203 & 190 \\
\hline & $N$ & 80 & 180 & 40 & 6.9 & 1.7 & 0.9 & 0.8 & 8.0 & 0.1 & 12 & 7 & 1.8 & 3.2 & 0.01 & 1.08 & 39.29 & 10.06 & 0.50 & 0.14 & 0.22 & 0.09 & 0.02 & 0.02 & 158 & 135 \\
\hline & $\mathrm{N}$ & 80 & 180 & 80 & 21.1 & 3.2 & 3.3 & 2.3 & 8.1 & 0.2 & 28 & 18 & 2.1 & 19.9 & 0.03 & 2.24 & 53.99 & 9.15 & 2.18 & 0.27 & 0.27 & 0.15 & 0.02 & 0.02 & 197 & 72 \\
\hline & $N$ & 80 & 180 & 0 & 1.6 & 1.2 & 0.1 & 0.8 & 8.3 & 0.1 & 4 & 22 & 1.7 & 0.2 & 0.00 & 0.95 & 46.05 & 20.54 & 0.13 & 0.16 & 0.22 & 0.09 & 0.02 & 0.02 & 175 & 318 \\
\hline & $N$ & 160 & 359 & 0 & 1.5 & 0.4 & 0.1 & 0.8 & 8.3 & 0.1 & 4 & 26 & 1.8 & 3.1 & 0.00 & 0.99 & 45.97 & 10.98 & 0.17 & 0.13 & 0.22 & 0.09 & 0.03 & 0.04 & 186 & 495 \\
\hline & $\mathrm{N}$ & 260 & 359 & 10 & 2.7 & 0.4 & 0.5 & 0.8 & 8.2 & 0.1 & 1 & 25 & 2.0 & 0.2 & 0.01 & 1.29 & 48.13 & 10.69 & 0.61 & 0.15 & 0.22 & 0.09 & 0.02 & 0.02 & 187 & 258 \\
\hline & $\mathrm{N}$ & 160 & 359 & 20 & 4.1 & 0.4 & 0.9 & 0.7 & 8.3 & 0.1 & 1 & 21 & 2.1 & 0.7 & 0.01 & 1.08 & 38.54 & 7.72 & 0.50 & 0.16 & 0.22 & 0.11 & 0.02 & 0.02 & 210 & 235 \\
\hline & $\mathrm{N}$ & 160 & 359 & 40 & 5.8 & 0.4 & 0.9 & 0.7 & 8.4 & 0.1 & 1 & 14 & 1.9 & 1.1 & 0.01 & 0.90 & 37.03 & 8.35 & 0.38 & 0.12 & 0.22 & 0.09 & 0.06 & 0.02 & 250 & 213 \\
\hline & $N$ & 260 & 359 & 80 & 64.8 & 0.4 & 2.2 & 4.5 & 8.1 & 0.2 & 22 & 32 & 2.3 & 21.6 & 0.05 & 3.11 & 781.9 & 44.74 & 22.5 & 0.67 & 2.37 & 0.51 & 0.05 & 0.02 & 2216 & 69 \\
\hline & $\mathrm{N}$ & 160 & 359 & 0 & 2.8 & 0.4 & 0.1 & 1.0 & 8.4 & 0.1 & 3 & 16 & 1.9 & 2.3 & 0.00 & 1.27 & 51.75 & 11.46 & 0.22 & 0.24 & 0.48 & 0.11 & 0.03 & 0.02 & 262 & 423 \\
\hline & I & 0 & 0 & 0 & 1.6 & 0.4 & 0.1 & 1.1 & 8.6 & 0.1 & 3 & 2 & 1.7 & 0.4 & 0.02 & 1.08 & 58.52 & 15.26 & 0.11 & 0.17 & 0.22 & 0.17 & 0.02 & 0.02 & 223 & 180 \\
\hline & $I$ & 0 & 0 & 10 & 2.4 & 0.4 & 0.1 & 1.1 & 8.4 & 0.1 & 3 & 1 & 1.7 & 1.8 & 0.02 & 1.09 & 53.41 & 12.54 & 0.25 & 0.16 & 0.68 & 0.13 & 0.02 & 0.02 & 212 & 218 \\
\hline & I & 0 & 0 & 20 & 3.0 & 0.4 & 0.1 & 1.3 & 8.4 & 0.1 & 3 & 1 & 1.8 & 0.4 & 0.00 & 1.27 & 49.29 & 12.50 & 0.25 & 0.15 & 1.16 & 0.09 & 0.02 & 0.02 & 243 & 318 \\
\hline & $I$ & 0 & 0 & 40 & 5.0 & 0.5 & 0.8 & 1.0 & 8.5 & 0.1 & 2 & 1 & 1.7 & 1.9 & 0.01 & 1.01 & 12.10 & 9.71 & 0.45 & 0.13 & 0.58 & 0.09 & 0.02 & 0.02 & 166 & 202 \\
\hline & I & 0 & 0 & 80 & 5.7 & 0.5 & 0.1 & 0.9 & 8.5 & 0.1 & 1 & 1 & 1.8 & 0.6 & 0.01 & 1.08 & 46.66 & 21.11 & 0.45 & 0.14 & 0.58 & 0.09 & 0.02 & 0.04 & 292 & 280 \\
\hline & $\mathrm{I}$ & 0 & 0 & 0 & 2.8 & 2.4 & 0.1 & 1.0 & 8.5 & 0.1 & 4 & 1 & 1.8 & 0.1 & 0.00 & 0.77 & 56.60 & 13.53 & 0.20 & 0.14 & 0.26 & 0.09 & 0.02 & 0.04 & 212 & 384 \\
\hline & I & 80 & 180 & 0 & 2.6 & 0.4 & 0.1 & 1.1 & 8.4 & 0.1 & 2 & 10 & 2.7 & 0.1 & 0.00 & 1.04 & 45.22 & 10.14 & 0.17 & 0.13 & 0.84 & 0.20 & 0.02 & 0.06 & 220 & 260 \\
\hline & I & 80 & 180 & 10 & 1.0 & 0.4 & 0.1 & 1.3 & 8.4 & 0.1 & 1 & 10 & 1.8 & 0.7 & 0.02 & 0.85 & 13.29 & 10.30 & 0.21 & 0.13 & 0.39 & 0.09 & 0.02 & 0.02 & 236 & 242 \\
\hline & I & 80 & 180 & 20 & 1.9 & 0.4 & 1.2 & 1.2 & 8.3 & 0.1 & 1 & 23 & 1.9 & 2.6 & 0.01 & 1.16 & 34.97 & 7.73 & 0.32 & 0.12 & 0.84 & 0.12 & 0.02 & 0.02 & 270 & 126 \\
\hline & \pm & 80 & 180 & 40 & 4.1 & 0.4 & 0.9 & 1.1 & 8.3 & 0.1 & 2 & 14 & 2.5 & 3.6 & 0.01 & 0.96 & 35.17 & 8.17 & 0.37 & 0.14 & 0.32 & 0.09 & 0.02 & 0.02 & 235 & 96 \\
\hline & $I$ & 80 & 180 & 80 & 10.2 & 0.4 & 0.1 & 2.4 & 8.3 & 0.2 & 2 & 12 & 2.2 & 8.2 & 0.03 & 1.59 & 78.77 & 20.81 & 2.14 & 0.34 & 0.58 & 0.27 & 0.02 & 0.08 & 232 & 50 \\
\hline & I & 80 & 180 & 0 & 1.6 & 0.4 & 0.1 & 1.4 & 8.4 & 0.1 & 1 & 5 & 2.0 & 0.1 & 0.00 & 0.96 & 52.69 & 12.27 & 0.19 & 0.16 & 0.58 & 0.09 & 0.02 & 0.02 & 221 & 329 \\
\hline & 1 & 150 & 359 & 0 & 1.2 & 0.4 & 0.8 & 1.0 & 8.1 & 0.3 & 15 & 13 & 1.8 & 0.1 & 0.00 & 1.06 & 46.77 & 11.35 & 0.15 & 0.17 & 0.45 & 0.09 & 0.02 & 0.06 & 364 & 265 \\
\hline & $\mathrm{I}$ & 160 & 359 & 10 & 0.8 & 0.4 & 0.9 & 0.7 & 8.3 & 0.2 & 2 & 21 & 1.7 & 0.7 & 0.01 & 1.01 & 10.52 & 9.91 & 0.27 & 0.18 & 0.39 & 0.12 & 0.02 & 0.02 & 276 & 122 \\
\hline & $I$ & 160 & 359 & 20 & 1.6 & 0.4 & 1.7 & 1.1 & 8.2 & 0.1 & 2 & 35 & 1.9 & 2.3 & 0.01 & 1.01 & 35.31 & 8.89 & 0.40 & 0.15 & 0.39 & 0.14 & 0.02 & 0.03 & 247 & 72 \\
\hline & I & 150 & 359 & 40 & 4.2 & 0.4 & 0.7 & 1.4 & 8.1 & 0.1 & 1 & 19 & 1.9 & 2.8 & 0.01 & 1.18 & 36.80 & 8.84 & 0.42 & 0.16 & 0.54 & 0.10 & 0.02 & 0.03 & 282 & 107 \\
\hline & $I$ & 160 & 359 & 80 & 25.6 & 0.4 & 0.4 & 2.0 & 8.1 & 0.2 & 16 & 17 & 1.9 & 10.2 & 0.03 & 3.08 & 66.49 & 13.04 & 7.85 & 0.34 & 1.16 & 0.22 & 0.02 & 0.06 & 226 & 99 \\
\hline u & $I$ & 160 & 359 & 0 & 1.4 & 0.4 & 0.1 & 0.9 & 8.2 & 0.1 & 1 & 14 & 1.8 & 1.9 & 0.01 & 1.06 & 48.50 & 12.34 & 0.24 & 0.15 & 0.77 & 0.10 & 0.02 & 0.04 & 258 & 212 \\
\hline
\end{tabular}



A-3.--Continued

\begin{tabular}{|c|c|c|c|c|c|c|c|c|c|c|c|c|c|c|c|c|c|c|c|c|c|c|c|c|c|}
\hline Plat & $N$ & P205 & Res & Mois & No3 & $\mathrm{NH4}$ & oxg & $\mathrm{pH}$ & $E C 1: 1$ & 504 & $01 s$ & $C E C$ & $\mathrm{Cl}$ & Tot & TOC & $\mathrm{Fe}$ & $\mathrm{Mn}$ & $\mathrm{zn}$ & $\mathrm{cu}$ & $\mathrm{Pb}$ & $\mathrm{Ni}$ & $c d$ & $c r$ & P & $C: N$ \\
\hline Type & $\begin{array}{l}1 \mathrm{~b} / \\
\mathrm{ac}\end{array}$ & $\begin{array}{l}1 \mathrm{D} / \\
\mathrm{ac}\end{array}$ & $\begin{array}{l}\mathrm{cn} / \\
\mathrm{ac}\end{array}$ & $t$ & $\begin{array}{l}-\mathrm{N} \\
\mathrm{ppm}\end{array}$ & $\begin{array}{l}-\mathrm{N} \\
\mathrm{ppm}\end{array}$ & $\begin{array}{l}\text { Mat } \\
+\end{array}$ & & $\begin{array}{l}\text { manhos } \\
/ \mathrm{cm}\end{array}$ & $\begin{array}{l}-s \\
\mathrm{ppm}\end{array}$ & -P & $\begin{array}{l}\text { meq/ } \\
100 \mathrm{~g}\end{array}$ & $\mathrm{ppm}$ & N & $t$ & $\mathrm{ppm}$ & $\mathrm{ppm}$ & $\mathrm{ppm}$ & $\mathrm{ppm}$ & ppm & $\mathrm{ppm}$ & $\mathrm{ppm}$ & ppm & $\mathrm{ppm}$ & RAL \\
\hline $\mathrm{N}$ & 0 & 0 & 0 & 3.8 & 0.6 & 0.1 & 1.1 & 8.1 & 0.1 & 1 & 2 & 1.9 & 0.6 & 0.02 & 0.60 & 57.00 & 15.92 & 0.07 & 0.23 & 0.17 & 0.06 & 0.02 & 0.03 & 189 & 60 \\
\hline N & 0 & 0 & 10 & 4.7 & 0.3 & 0.2 & 1.1 & 8.5 & 0.1 & 1 & 2 & 2.1 & 1.3 & 0.01 & 0.70 & 41.73 & 21.17 & 0.10 & 0.21 & 0.17 & 0.04 & 0.01 & 0.03 & 216 & 70 \\
\hline $\mathrm{N}$ & 0 & 0 & 20 & 4.9 & 0.2 & 0.1 & 1.0 & 8.4 & 0.1 & 1 & 2 & 1.8 & 3.3 & 0.01 & 0.60 & 39.40 & 9.21 & 0.16 & 0.27 & 0.17 & 0.04 & 0.01 & 0.03 & 168 & 60 \\
\hline$N$ & 0 & 0 & 40 & 5.3 & 0.6 & 0.1 & 1.4 & 8.5 & 0.1 & $I$ & 2 & 1.9 & 13.2 & 0.02 & 0.84 & 38.81 & 10.91 & 0.30 & 0.26 & 0.17 & 0.04 & 0.01 & 0.03 & 295 & 32 \\
\hline $\mathrm{N}$ & 0 & 0 & 80 & 7.3 & 0.1 & 0.1 & 2.8 & 8.3 & 0.1 & 1 & 2 & 2.2 & 2.0 & 0.01 & 1.40 & 38.47 & 8.57 & 0.78 & 0.27 & 0.17 & 0.04 & 0.02 & 0.03 & 211 & 240 \\
\hline $\mathrm{s}$ & 0 & 0 & 0 & 3.8 & 0.5 & 0.1 & 2.6 & 8.4 & 0.1 & 2 & 1 & 2.0 & 2.7 & 0.01 & 0.52 & 57.01 & 14.07 & 0.02 & 0.32 & 0.27 & 0.05 & 0.01 & 0.03 & 199 & 52 \\
\hline $\mathrm{N}$ & Bo & 280 & 0 & 3.8 & 1.6 & 0.1 & 2.7 & 8.1 & 0.1 & 1 & 24 & 1.8 & 3.3 & 0.01 & 0.61 & 43.32 & 10.76 & 0.01 & 0.22 & 0.17 & 0.05 & 0.01 & 0.03 & 197 & 61 \\
\hline$N$ & 80 & 180 & 10 & 4.5 & 1.5 & 1.2 & 2.2 & 8.2 & 0.2 & 1 & 22 & 1.8 & 1.1 & 0.01 & 0.54 & 33.00 & 7.53 & 0.21 & 0.16 & 0.17 & 0.07 & 0.01 & 0.03 & 249 & 54 \\
\hline $\mathrm{N}$ & 80 & 180 & 20 & 5.1 & 1.4 & 2.0 & 1.3 & 8.2 & 0.1 & 1 & 15 & 2.0 & 0.5 & 0.01 & 0.51 & 36.59 & 8.65 & 0.29 & 0.46 & 0.17 & 0.04 & 0.01 & 0.03 & 235 & 51 \\
\hline$N$ & 80 & 180 & 40 & 7.9 & 0.6 & 3.3 & 2.6 & 8.3 & 0.1 & 1 & 15 & 1.9 & 8.8 & 0.02 & 1.00 & 30.33 & 7.53 & 1.14 & 0.21 & 0.17 & 0.05 & 0.01 & 0.03 & 284 & 50 \\
\hline $\mathrm{N}$ & 80 & 180 & 80 & 22.8 & 0.5 & 2.7 & 3.8 & 7.6 & 0.3 & 6 & 42 & 2.2 & 12.2 & 0.04 & 1.82 & 32.69 & 17.68 & 2.11 & 0.55 & 0.17 & 0.11 & 0.01 & 0.03 & 367 & 46 \\
\hline $\mathrm{N}$ & 80 & 180 & 0 & 1.2 & 2.5 & 0.3 & 1.1 & 8.0 & 0.1 & 1 & 30 & 2.9 & 2.6 & 0.01 & 0.41 & 42.85 & 9.72 & 0.01 & 0.19 & 0.17 & 0.06 & 0.01 & 0.03 & 273 & 42 \\
\hline $\mathrm{N}$ & 160 & 359 & 0 & 4.3 & 4.0 & 2.4 & 1.4 & 7.9 & 0.1 & 1 & 39 & 2.0 & 5.8 & 0.01 & 0.58 & 44.59 & 11.49 & 0.01 & 0.22 & 0.17 & 0.05 & 0.01 & 0.03 & 328 & 58 \\
\hline $\mathrm{N}$ & 160 & 359 & 10 & 5.2 & 10.5 & 3.2 & 2.4 & 7.8 & 0.2 & 1 & 58 & 2.0 & 0.5 & 0.02 & 0.64 & 29.75 & 7.82 & 0.28 & 0.14 & 0.17 & 0.07 & 0.02 & 0.03 & 310 & 32 \\
\hline N & 160 & 359 & 20 & 6.2 & 3.3 & 4.4 & 0.8 & 8.0 & 0.2 & 1 & 51 & 1.9 & 3.1 & 0.02 & 0.59 & 28.46 & 7.04 & 0.45 & 0.15 & 0.17 & 0.06 & 0.01 & 0.03 & 424 & 30 \\
\hline $\mathrm{N}$ & 160 & 359 & 40 & 9.8 & 0.4 & 4.3 & 1.0 & 7.9 & 0.2 & 1 & 49 & 1.8 & 3.3 & 0.03 & 0.87 & 22.73 & 5.59 & 1.23 & 0.30 & 0.17 & 0.06 & 0.01 & 0.03 & 325 & 29 \\
\hline N & 160 & 359 & 80 & 21.7 & 0.6 & 3.0 & 1.2 & 8.0 & 0.2 & 1 & 24 & 1.9 & 11.7 & 0.03 & 1.19 & 30.55 & 9.69 & 1.68 & 0.39 & 0.17 & 0.05 & 0.01 & 0.03 & 254 & 40 \\
\hline $\mathrm{N}$ & 260 & 359 & 0 & 4.0 & 5.2 & 0.9 & 0.6 & 8.0 & 0.1 & 1 & 30 & 1.9 & 0.5 & 0.01 & 0.54 & 44.89 & 11.00 & 0.01 & 0.31 & 0.17 & 0.05 & 0.01 & 0.03 & 253 & 54 \\
\hline I & 0 & 0 & 0 & 3.9 & 2.1 & 0.1 & 0.8 & 8.5 & 0.1 & 1 & 2 & 1.8 & 0.5 & 0.01 & 0.58 & 59.83 & 16.32 & 0.04 & 0.25 & 0.17 & 0.05 & 0.02 & 0.03 & 288 & 58 \\
\hline$I$ & 0 & 0 & 10 & 4.5 & 0.5 & 0.5 & 1.0 & 8.2 & 0.1 & 1 & 1 & 1.7 & 0.5 & 0.01 & 0.76 & 53.35 & 13.16 & 0.05 & 0.21 & 0.17 & 0.05 & 0.01 & 0.03 & 192 & 76 \\
\hline I & 0 & 0 & 20 & 4.3 & 0.5 & 0.2 & 1.1 & 8.5 & 0.2 & 1 & 1 & 1.7 & 0.5 & 0.01 & 0.51 & 46.69 & 13.09 & 0.06 & 0.24 & 0.17 & 0.04 & 0.01 & 0.03 & 156 & 51 \\
\hline I & 0 & 0 & 40 & 7.2 & 0.8 & 2.2 & 1.6 & 8.2 & 0.1 & 1 & 6 & 1.7 & 5.1 & 0.01 & 0.75 & 32.45 & 6.76 & 0.45 & 0.17 & 0.17 & 0.04 & 0.01 & 0.03 & 217 & 75 \\
\hline I & 0 & 0 & 80 & 6.2 & 0.2 & 0.3 & 0.8 & 8.3 & 0.1 & 1 & 4 & 1.5 & 3.5 & 0.01 & 0.70 & 29.66 & 6.44 & 0.65 & 0.33 & 0.17 & 0.04 & 0.02 & 0.03 & 247 & 70 \\
\hline I & 0 & 0 & 0 & 4.1 & 0.9 & 0.7 & 0.7 & 8.3 & 0.1 & 3 & 1 & 1.7 & 0.5 & 0.02 & 0.42 & 54.00 & 13.58 & 0.38 & 0.21 & 0.17 & 0.05 & 0.01 & 0.03 & 187 & 42 \\
\hline$I$ & 80 & 280 & 0 & 4.1 & 5.3 & 0.7 & 0.8 & 8.2 & 0.1 & 1 & 11 & 1.8 & 2.0 & 0.02 & 0.58 & 10.72 & 10.21 & 0.13 & 0.27 & 0.17 & 0.05 & 0.01 & 0.03 & 210 & 58 \\
\hline I & 80 & 280 & 10 & 4.8 & 3.2 & 1.7 & 0.7 & 8.2 & 0.1 & 1 & 21 & 1.9 & 0.6 & 0.01 & 0.89 & 35.88 & 7.61 & 0.15 & 0.21 & 0.17 & 0.06 & 0.01 & 0.03 & 234 & 89 \\
\hline I & 80 & 280 & 20 & 5.2 & 1.8 & 2.4 & 0.7 & 8.1 & 0.2 & 1 & 16 & 1.7 & 2.6 & 0.01 & 0.63 & 30.42 & 7.09 & 0.31 & 0.19 & 0.17 & 0.06 & 0.01 & 0.03 & 216 & 63 \\
\hline I & 80 & 280 & 40 & 7.4 & 0.5 & 3.4 & 1.0 & 8.1 & 0.2 & 1 & 34 & 2.0 & 10.8 & 0.02 & 0.97 & 31.06 & 8.39 & 0.82 & 0.23 & 0.17 & 0.05 & 0.01 & 0.03 & 335 & 49 \\
\hline I & 80 & 180 & 80 & 14.9 & 0.4 & 2.8 & 1.7 & 8.0 & 0.2 & 7 & 20 & 1.9 & 8.5 & 0.02 & 1.59 & 28.30 & 8.78 & 2.12 & 0.47 & 0.17 & 0.06 & 0.01 & 0.03 & 232 & 80 \\
\hline : & 80 & 280 & 0 & 4.1 & 2.1 & 0.7 & 0.8 & 8.0 & 0.1 & 1 & 16 & 1.9 & 3.2 & 0.01 & 0.76 & 46.70 & 11.74 & 0.05 & 0.24 & 0.17 & 0.05 & 0.01 & 0.03 & 256 & 75 \\
\hline I & 160 & 359 & 0 & 4.2 & 7.5 & 1.7 & 1.1 & 7.7 & 0.2 & 1 & 29 & 1.9 & 1.5 & 0.03 & 0.64 & 43.31 & 12.16 & 0.05 & 0.25 & 0.17 & 0.05 & 0.01 & 0.03 & 278 & 21 \\
\hline I & 260 & 359 & 10 & 5.1 & 12.0 & 2.7 & 1.1 & 7.7 & 0.2 & 1 & 36 & 1.9 & 1.9 & 0.03 & 0.62 & 32.45 & 9.30 & 0.25 & 0.14 & 0.17 & 0.07 & 0.01 & 0.03 & 291 & 21 \\
\hline I & 160 & 359 & 20 & 5.7 & 24.0 & 1.9 & 1.0 & 7.6 & 0.2 & 1 & 40 & 1.9 & 1.6 & 0.01 & 0.56 & 32.30 & 7.85 & 0.26 & 0.19 & 0.17 & 0.07 & 0.01 & 0.03 & 342 & 56 \\
\hline I & 160 & 359 & 40 & 7.0 & 0.8 & 6.8 & 2.2 & 7.8 & 0.1 & 1 & 41 & 2.0 & 3.3 & 0.02 & 0.84 & 28.18 & 7.97 & 0.89 & 0.22 & 0.17 & 0.05 & 0.01 & 0.03. & 280 & 42 \\
\hline I & 160 & 359 & 80 & 9.1 & 1.4 & 3.4 & 1.2 & 8.0 & 0.2 & 3 & 17 & 1.9 & 7.2 & 0.02 & 1.00 & 34.98 & 12.28 & 1.01 & 0.29 & 0.17 & 0.04 & 0.01 & 0.03 & 220 & 50 \\
\hline I & 160 & 359 & 0 & 4.3 & 4.4 & 1.0 & 1.0 & 7.9 & 0.1 & 3 & 25 & 2.9 & 1.6 & 0.01 & 0.47 & 43.96 & 11.62 & 0.01 & 0.27 & 0.17 & 0.04 & 0.01 & 0.03 & 279 & 47 \\
\hline
\end{tabular}


A-4.--Nutrient analysis of coarse tailings/residue mixture, fall 1993.

\begin{tabular}{|c|c|c|c|c|c|c|c|c|c|c|c|c|c|c|c|c|c|c|c|c|c|c|c|c|c|}
\hline $\begin{array}{l}\text { Plat } \\
\text { Type }\end{array}$ & $\begin{array}{l}\text { N } \\
1 \mathrm{~b} / \\
\mathrm{ac}\end{array}$ & $\begin{array}{l}9205 \\
1 \mathrm{~b} / \\
\mathrm{ac}\end{array}$ & $\begin{array}{l}\text { Res } \\
\mathrm{En} / \\
\mathrm{ac}\end{array}$ & $\begin{array}{l}\text { Mols } \\
t\end{array}$ & $\begin{array}{l}\mathrm{NO3} \\
-\mathrm{N} \\
\mathrm{pPm}\end{array}$ & $\begin{array}{l}\mathrm{NH} 4 \\
-\mathrm{N} \\
\mathrm{ppm}\end{array}$ & $\begin{array}{l}\text { org } \\
\text { Mat } \\
t\end{array}$ & $\mathrm{pH}$ & $\begin{array}{l}\mathrm{BC} 1: 1 \\
\text { mahos } \\
/ \mathrm{cm}\end{array}$ & $\begin{array}{l}\mathrm{SO4} \\
-\mathrm{s} \\
\mathrm{ppm}\end{array}$ & $\begin{array}{l}\text { Ols } \\
-P \\
\text { ppm }\end{array}$ & $\begin{array}{l}\text { CEC } \\
\text { meq/ } \\
2009\end{array}$ & $\begin{array}{l}\mathrm{Cl} \\
\mathrm{ppm}\end{array}$ & $\begin{array}{l}\text { Tot } \\
\text { N } \\
t\end{array}$ & $\begin{array}{l}\text { TOC } \\
\text { : }\end{array}$ & $\begin{array}{l}\mathrm{Fe} \\
\mathrm{ppm}\end{array}$ & $\begin{array}{l}\mathrm{Mn} \\
\mathrm{ppm}\end{array}$ & $\begin{array}{l}\text { 2n } \\
\mathrm{ppm}\end{array}$ & $\begin{array}{l}\mathrm{Cu} \\
\mathrm{ppm}\end{array}$ & $\begin{array}{l}\mathrm{Pb} \\
\mathrm{ppm}\end{array}$ & $\begin{array}{l}\mathrm{N} 1 \\
\mathrm{PPm}\end{array}$ & $\begin{array}{l}\text { cd } \\
\text { pprn }\end{array}$ & $\begin{array}{l}\mathrm{Cr} \\
\mathrm{ppm}\end{array}$ & $\begin{array}{l}\mathrm{P} \\
\mathrm{ppm}\end{array}$ & $\begin{array}{l}\mathrm{C}: \mathrm{N} \\
\mathrm{Ra}=\end{array}$ \\
\hline $\mathrm{N}$ & 0 & 0 & 0 & 3.0 & 0.2 & 0.3 & 1.2 & 8.5 & 0.1 & 1 & 2 & 2.0 & 0.4 & 0.01 & 1.07 & 55.76 & 14.10 & 0.06 & 0.23 & 0.17 & 0.05 & 0.01 & 0.03 & 275 & 107 \\
\hline$N$ & 0 & 0 & 10 & 4.3 & 0.1 & 0.3 & 0.8 & 8.5 & 0.1 & 1 & 2 & 1.6 & 0.9 & 0.01 & 0.99 & 47.00 & 9.92 & 0.12 & 0.23 & 0.17 & 0.04 & 0.01 & 0.03 & 169 & 99 \\
\hline $\mathrm{N}$ & 0 & 0 & 20 & 6.1 & 0.2 & 0.2 & 1.0 & 8.5 & 0.2 & 1 & 1 & 2.6 & 0.7 & 0.02 & 1.14 & 54.74 & 12.70 & 0.08 & 0.25 & 0.17 & 0.04 & 0.01 & 0.03 & 174 & 214 \\
\hline$N$ & 0 & 0 & 40 & 6.8 & 0.1 & 0.2 & 0.9 & 8.5 & 0.1 & 1 & 1 & 1.7 & 0.8 & 0.01 & 1.18 & 50.92 & 13.57 & 0.08 & 0.12 & 0.17 & 0.04 & 0.02 & 0.03 & 163 & 118 \\
\hline $\mathrm{N}$ & 0 & 0 & 80 & 11.8 & 0.2 & 0.3 & 1.1 & 8.5 & 0.1 & 1 & 2 & 1.5 & 2.5 & 0.01 & 1.28 & 43.60 & 10.30 & 0.20 & 0.24 & 0.17 & 0.04 & 0.01 & 0.03 & 224 & 228 \\
\hline $\mathrm{N}$ & 0 & 0 & 0 & 3.4 & 0.2 & 0.3 & 0.9 & 8.6 & 0.1 & 1 & 1 & 1.5 & 0.5 & 0.01 & 1.01 & 55.16 & 13.21 & 0.03 & 0.18 & 0.17 & 0.06 & 0.01 & 0.03 & 146 & 101 \\
\hline $\mathrm{N}$ & 36 & 92 & 0 & 3.3 & 0.1 & 0.3 & 0.9 & 8.4 & 0.1 & 1 & 6 & 1.6 & 0.3 & 0.01 & 0.92 & 48.82 & 11.68 & 0.04 & 0.13 & 0.17 & 0.05 & 0.01 & 0.03 & 179 & 92 \\
\hline$N$ & 36 & 92 & 10 & 4.3 & 0.1 & 0.3 & 0.8 & 8.3 & 0.2 & 8 & 23 & 1.5 & 0.6 & 0.01 & 0.91 & 35.89 & 6.65 & 0.17 & 0.17 & 0.27 & 0.07 & 0.01 & 0.03 & 169 & 91 \\
\hline$N$ & 36 & 92 & 20 & 4.3 & 1.4 & 0.3 & 0.9 & 8.4 & 0.2 & 1 & 5 & 1.8 & 0.9 & 0.01 & 1.10 & 38.50 & 7.40 & 0.17 & 0.16 & 0.17 & 0.07 & 0.01 & 0.03 & 200 & 110 \\
\hline$N$ & 36 & 92 & 40 & 9.7 & 0.1 & 0.5 & 1.4 & 8.5 & 0.1 & 1 & 4 & 1.6 & 1.6 & 0.01 & 1.65 & 37.64 & 10.22 & 0.43 & 0.54 & 0.17 & 0.04 & 0.01 & 0.03 & 256 & 265 \\
\hline $\mathrm{N}$ & 36 & 92 & 80 & 11.8 & 0.1 & 0.3 & 1.1 & 8.5 & 0.2 & 1 & 2 & 1.5 & 1.2 & 0.01 & 1.30 & 38.23 & 8.89 & 0.14 & 0.16 & 0.17 & 0.05 & 0.01 & 0.03 & 168 & 230 \\
\hline $\mathrm{N}$ & 36 & 92 & 0 & 3.2 & 0.1 & 0.2 & 0.8 & 8.4 & 0.1 & 1 & 3 & 1.5 & 0.3 & 0.01 & 1.04 & 46.86 & 12.05 & 0.03 & 0.19 & 0.17 & 0.05 & 0.01 & 0.03 & 196 & 104 \\
\hline N & 72 & 184 & 0 & 4.1 & 0.1 & 0.1 & 1.1 & 8.3 & 0.2 & 6 & 13 & 1.2 & 0.4 & 0.01 & 1.13 & 44.18 & 12.47 & 0.03 & 0.15 & 0.17 & 0.04 & 0.01 & 0.03 & 189 & 113 \\
\hline$x$ & 72 & 284 & 20 & 3.9 & 0.1 & 0.2 & 1.0 & 8.3 & 0.2 & 5 & 15 & 1.9 & 0.2 & 0.01 & 1.29 & 42.35 & $8.06^{\circ}$ & 0.11 & 0.24 & 0.17 & 0.05 & 0.01 & 0.03 & 260 & 129 \\
\hline N & 72 & 284 & 20 & 4.1 & 1.4 & 0.3 & 1.0 & 8.3 & 0.2 & 1 & 17 & 2.3 & 0.8 & 0.01 & 1.13 & 39.10 & 8.40 & 0.12 & 0.20 & 0.17 & 0.04 & 0.01 & 0.03 & 261 & 123 \\
\hline$N$ & 72 & 184 & 40 & 6.0 & 0.7 & 0.1 & 0.9 & 8.3 & 0.1 & $I$ & 6 & 1.7 & 1.3 & 0.01 & 1.10 & 33.14 & 5.88 & 0.24 & 0.16 & 0.17 & 0.04 & 0.01 & 0.03 & 190 & 110 \\
\hline $\mathrm{N}$ & 72 & 184 & 80 & 7.0 & 1.4 & 0.3 & 1.1 & 8.3 & 0.1 & 1 & 7 & 1.9 & 2.3 & 0.01 & 1.24 & 40.13 & 8.62 & 0.14 & 0.14 & 0.17 & 0.04 & 0.02 & 0.03 & 194 & 224 \\
\hline N & 72 & 284 & 0 & 3.7 & 0.1 & 0.1 & 1.2 & 8.0 & 0.2 & 20 & 15 & 2.0 & 0.6 & 0.01 & 1.09 & 47.09 & 8.64 & 0.04 & 0.11 & 0.17 & 0.04 & 0.01 & 0.03 & 256 & 109 \\
\hline I & 0 & 0 & 0 & 3.1 & 0.3 & 0.2 & 1.2 & 8.6 & 0.1 & 1 & 1 & 1.8 & 0.9 & 0.01 & 1.03 & 60.84 & 14.36 & 0.04 & 0.17 & 0.17 & 0.05 & 0.01 & 0.03 & 178 & 103 \\
\hline$I$ & 0 & 0 & 10 & 3.9 & 0.1 & 0.1 & 1.1 & 8.4 & 0.1 & 1 & 1 & 2.7 & 0.4 & 0.01 & 1.24 & 56.78 & 12.45 & 0.07 & 0.13 & 0.17 & 0.04 & 0.01 & 0.03 & 196 & 124 \\
\hline I & 0 & 0 & 20 & 5.5 & 0.1 & 0.1 & 1.0 & 8.5 & 0.1 & 1 & 1 & 1.8 & 0.4 & 0.01 & 1.19 & 46.81 & 12.40 & 0.05 & 0.15 & 0.17 & 0.04 & 0.01 & 0.03 & 152 & 119 \\
\hline$I$ & 0 & 0 & 40 & 6.2 & 0.1 & 0.1 & 1.0 & 8.5 & 0.1 & 1 & 1 & 2.7 & 0.8 & 0.01 & 1.10 & 38.28 & 7.45 & 0.20 & 0.15 & 0.17 & 0.04 & 0.01 & 0.03 & 168 & 210 \\
\hline$I$ & 0 & 0 & 80 & 8.4 & 0.1 & 0.1 & 0.9 & 8.5 & 0.1 & 2 & 1 & 1.7 & 0.8 & 0.01 & 1.11 & 41.07 & 8.59 & 0.09 & 0.26 & 0.17 & 0.04 & 0.01 & 0.03 & 130 & 111 \\
\hline I & 0 & 0 & 0 & 3.5 & 0.3 & 0.1 & 1.0 & 8.3 & 0.1 & 2 & 1 & 1.8 & 0.4 & 0.01 & 1.11 & 50.06 & 12.38 & 0.03 & 0.12 & 0.17 & 0.04 & 0.02 & 0.03 & 130 & 211 \\
\hline : & 36 & 92 & 0 & 5.0 & 0.1 & 0.1 & 2.1 & 8.4 & 0.1 & 1 & 4 & 1.8 & 0.4 & 0.02 & 1.12 & 45.16 & 10.15 & 0.04 & 0.14 & 0.17 & 0.04 & 0.01 & 0.03 & 190 & 112 \\
\hline I & 36 & 92 & 10 & 4.8 & 2.0 & 0.3 & 0.7 & 8.3 & 0.2 & 8 & 4 & 2.0 & 0.6 & 0.01 & 1.16 & 43.20 & 9.19 & 0.27 & 0.13 & 0.17 & 0.04 & 0.01 & 0.03 & 172 & 126 \\
\hline 1 & 36 & 92 & 20 & 5.1 & 1.6 & 0.6 & 0.8 & 8.1 & 0.5 & 25 & 7 & 2.8 & 2.2 & 0.01 & 0.93 & 35.05 & 7.26 & 0.15 & 0.14 & 0.17 & 0.06 & 0.01 & 0.03 & 174 & 93 \\
\hline I & 36 & 92 & 40 & 5.8 & 0.1 & 0.6 & 0.8 & 8.3 & 0.2 & 40 & 8 & 2.0 & 2.7 & 0.01 & 1.13 & 34.41 & 3.16 & 0.21 & 0.12 & 0.17 & 0.04 & 0.01 & 0.03 & 162 & 113 \\
\hline I & 36 & 92 & 80 & 23.5 & 0.1 & 0.1 & 0.8 & 8.4 & 0.1 & 1 & 4 & 2.6 & 1.4 & 0.01 & 1.12 & 37.27 & 9.31 & 0.22 & 0.13 & 0.17 & 0.04 & 0.01 & 0.03 & 168 & 112 \\
\hline 1 & 36 & 92 & 0 & 4.2 & 0.1 & 0.1 & 0.8 & 8.5 & 0.1 & 8 & 4 & 1.9 & 0.8 & 0.01 & 1.06 & 54.75 & 13.57 & 0.04 & 0.15 & 0.17 & 0.04 & 0.01 & 0.03 & 179 & 206 \\
\hline 2 & 72 & 184 & 0 & 3.9 & 0.1 & 0.1 & 1.1 & 8.4 & 0.2 & 1 & 8 & 1.8 & 1.4 & 0.01 & 1.24 & 53.29 & 13.67 & 0.05 & 0.11 & 0.17 & 0.04 & 0.01 & 0.03 & 218 & 214 \\
\hline I & 72 & 184 & 10 & 3.2 & 5.2 & 0.4 & 0.8 & 8.1 & 0.3 & 12 & 20 & 1.9 & 1.0 & 0.01 & 1.20 & 36.30 & 7.16 & 0.15 & 0.16 & 0.17 & 0.05 & 0.01 & 0.03 & 229 & 120 \\
\hline I & 72 & 184 & 20 & 3.7 & 3.2 & 0.7 & 0.8 & 8.1 & 0.3 & 21 & 13 & 2.0 & 1.2 & 0.01 & 0.98 & 35.57 & 6.94 & 0.11 & 0.13 & 0.17 & 0.06 & 0.01 & 0.03 & 140 & 98 \\
\hline 2 & 72 & 184 & 40 & 4.6 & 3.9 & 0.8 & 0.8 & 8.1 & 0.2 & 2 & 13 & 1.9 & 2.9 & 0.01 & 1.02 & 32.19 & 5.99 & 0.27 & 0.14 & 0.17 & 0.05 & 0.01 & 0.03 & 179 & 102 \\
\hline I & 72 & 184 & 80 & 9.0 & 0.2 & 1.0 & 1.0 & 8.3 & 0.1 & 1 & 7 & 2.2 & 4.1 & 0.01 & 1.06 & 36.80 & 7.72 & 0.28 & 0.24 & 0.17 & 0.04 & 0.01 & 0.03 & 194 & 105 \\
\hline$I$ & 72 & 184 & 0 & 2.7 & 0.1 & 0.1 & 0.9 & 8.2 & 0.1 & 3 & 24 & 1.9 & 0.4 & 0.01 & 1.22 & 42.36 & 10.00 & 0.04 & 0.10 & 0.17 & 0.05 & 0.01 & 0.03 & 256 & 122 \\
\hline
\end{tabular}


A-4.--Continued

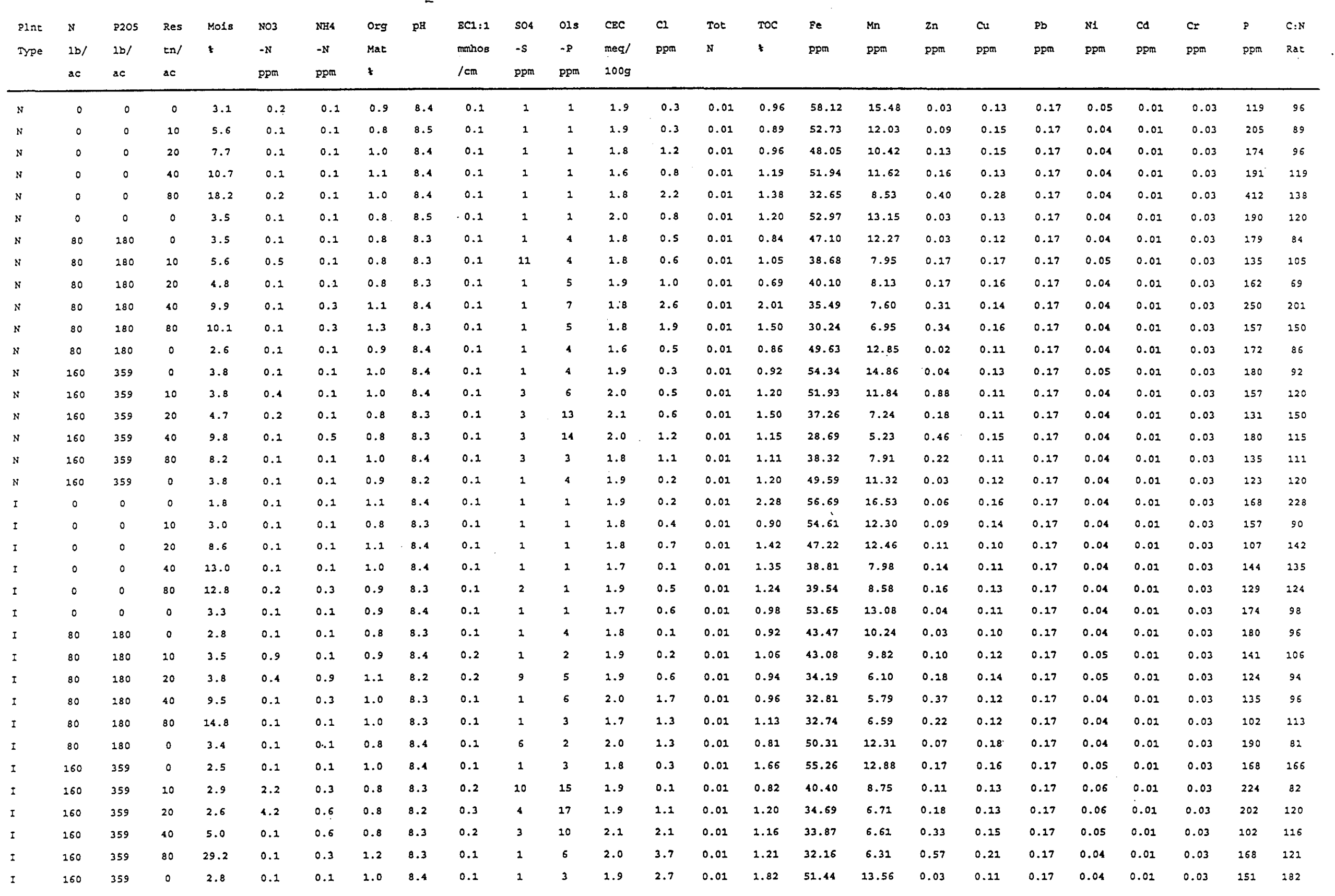




\section{APPENDIX B}

The chemical analyses for lysimeters sampled eight times in 1992 and 1993. 
B-1.--Lysimeter water analysis for June 1992.

\begin{tabular}{|c|c|c|c|c|c|c|c|c|c|}
\hline \multirow[b]{2}{*}{$\begin{array}{c}\text { Elements } \\
(\mathrm{mg} / \mathrm{l})\end{array}$} & \multicolumn{3}{|c|}{$0 \mathrm{1bs} / \mathrm{ac} \quad 18-46-0$} & \multicolumn{3}{|c|}{$2001 \mathrm{bs} / \mathrm{ac} \quad 18-46-0$} & \multicolumn{3}{|c|}{$4001 \mathrm{bs} / \mathrm{ac} \quad 18-46-0$} \\
\hline & $\begin{array}{c}0 \\
\text { tons/ac }\end{array}$ & $\begin{array}{c}20 \\
\text { tons } / \mathrm{ac} \\
\end{array}$ & $\begin{array}{c}80 \\
\text { tons/ac }\end{array}$ & $\begin{array}{c}0 \\
\text { tons } / \mathrm{ac}\end{array}$ & $\begin{array}{c}20 \\
\text { tons } / \mathrm{ac}\end{array}$ & $\begin{array}{c}80 \\
\text { tons/ac }\end{array}$ & $\begin{array}{c}0 \\
\text { tons } / \mathrm{ac}\end{array}$ & $\begin{array}{c}20 \\
\text { tons } / \mathrm{ac}\end{array}$ & $\begin{array}{c}80 \\
\text { tons/ac }\end{array}$ \\
\hline Aluminum & $<0.192$ & $<0.192$ & $<0.192$ & $<0.192$ & $<0.192$ & $<0.192$ & $<0.192$ & $<0.192$ & $<0.192$ \\
\hline Arsenic & 0.071 & 0.054 & 0.055 & 0.064 & 0.080 & 0.070 & 0.089 & 0.069 & 0.069 \\
\hline Barium & 0.024 & 0.117 & 0.023 & 0.025 & 0.033 & 0.018 & 0.015 & 0.011 & 0.012 \\
\hline Beryllium & $<0.002$ & $<0.002$ & $<0.002$ & $<0.002$ & $<0.002$ & $<0.002$ & $<0.002$ & $<0.002$ & $<0.002$ \\
\hline Boron & 0.127 & 0.130 & 0.113 & 0.125 & 0.164 & 0.110 & 0.112 & 0.085 & 0.086 \\
\hline Cadmium & $<0.006$ & $<0.006$ & $<0.006$ & $<0.006$ & $<0.006$ & $<0.006$ & $<0.006$ & $<0.006$ & $<0.006$ \\
\hline Calcium & 96.559 & 138.613 & 108.548 & 88.042 & 95.439 & 90.823 & 75.950 & 64.989 & 77.057 \\
\hline Chloride & 60.75 & 66.99 & 60.29 & 63.99 & 81.33 & 55.26 & 58.82 & 69.71 & 63.58 \\
\hline Chromium & $<0.015$ & $<0.015$ & $<0.015$ & $<0.015$ & 0.019 & $<0.015$ & $<0.015$ & $<0.015$ & $<0.015$ \\
\hline Cobalt & $<0.013$ & 0.020 & $<0.014$ & $<0.013$ & $<0.014$ & 0.015 & $<0.013$ & $<0.013$ & $<0.013$ \\
\hline Copper & $<0.028$ & $<0.028$ & $<0.028$ & $<0.028$ & $<0.028$ & $<0.028$ & $<0.028$ & $<0.028$ & $<0.028$ \\
\hline Iron & $<0.018$ & 0.055 & $<0.018$ & $<0.018$ & 0.019 & $<0.018$ & $<0.018$ & $<0.018$ & $<0.018$ \\
\hline Lead & $<0.090$ & $<0.090$ & $<0.090$ & $<0.090$ & $<0.090$ & $<0.090$ & $<0.090$ & $<0.090$ & $<0.090$ \\
\hline Lithium & 0.108 & 0.101 & 0.095 & 0.103 & 0.064 & 0.092 & 0.107 & 0.104 & 0.113 \\
\hline Magnesium & 40.246 & 57.975 & 41.585 & 33.296 & 119.335 & 37.810 & 47.525 & 29.240 & 36.697 \\
\hline Manganese & 0.586 & 1.669 & 0.326 & 0.401 & 0.565 & 0.428 & 0.149 & 0.091 & 0.061 \\
\hline Molybdenum & 0.034 & 0.043 & 0.036 & 0.037 & 0.032 & 0.032 & 0.060 & 0.042 & 0.050 \\
\hline Nickel & $<0.022$ & 0.066 & 0.036 & 0.038 & 0.044 & 0.027 & $<0.024$ & 0.029 & $<0.024$ \\
\hline Phosphorus & 0.317 & 0.464 & 0.317 & 0.261 & 0.209 & 0.257 & 0.375 & 0.321 & 0.341 \\
\hline Potassium & 18.896 & 31.537 & 11.348 & 23.030 & 13.697 & 11.472 & 11.792 & 11.906 & 11.767 \\
\hline Rubidium & $<2.836$ & $<2.836$ & $<2.836$ & $<2.836$ & $<2.836$ & $<2.836$ & $<2.836$ & $<2.836$ & $<2.836$ \\
\hline Silicon & 41.575 & 44.805 & 42.006 & 43.402 & 38.222 & 40.699 & 41.151 & 42.596 & 40.583 \\
\hline Sodium & 38.722 & 83.169 & 34.878 & 39.898 & $56.958^{\circ}$ & 33.017 & 48.107 & 41.151 & 36.457 \\
\hline strontium & 0.696 & 1.096 & 0.667 & 0.702 & 0.558 & 0.586 & 0.623 & 0.509 & 0.579 \\
\hline Sulfate & 32.58 & 72.65 & 39.98 & 30.78 & 70.16 & 29.18 & 37.32 & 29.44 & 33.59 \\
\hline Sulfur & 30.848 & 68.845 & 38.490 & 28.774 & 64.719 & 28.041 & 35.105 & 27.961 & 32.647 \\
\hline Titanium & $<0.016$ & $<0.016$ & $<0.016$ & $<0.016$ & $<0.016$ & $<0.016$ & $<0.016$ & $<0.016$ & $<0.016$ \\
\hline vanadium & 0.439 & 0.311 & 0.316 & 0.303 & 0.410 & 0.319 & 0.550 & 0.388 & 0.652 \\
\hline Zinc & 0.010 & 0.015 & 0.010 & 0.012 & 0.015 & 0.018 & 0.011 & $<0.007$ & 0.025 \\
\hline
\end{tabular}


B-2.--Lysimeter water analysis for July 1992.

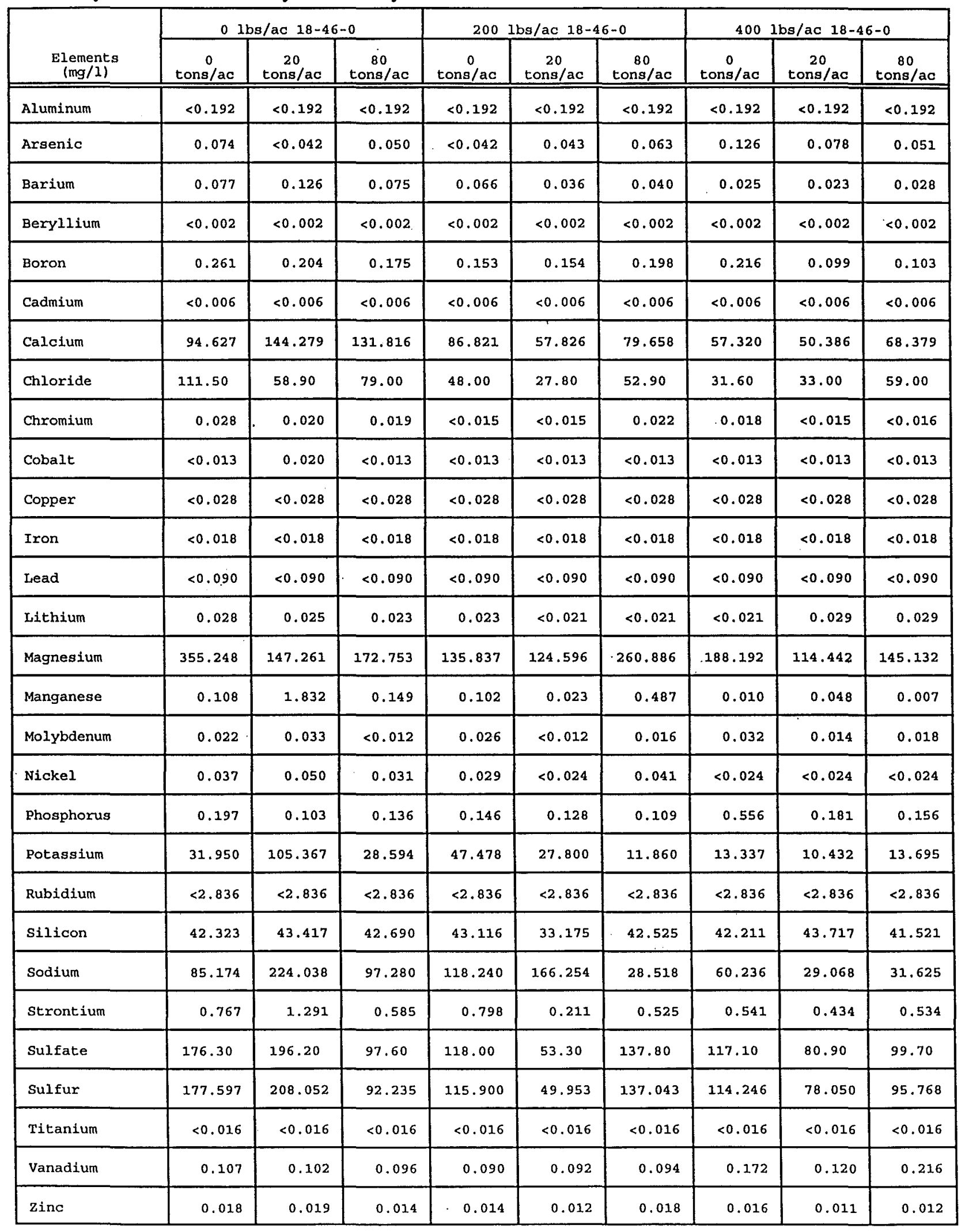


B-3.--Lysimeter water analysis for August 1992.

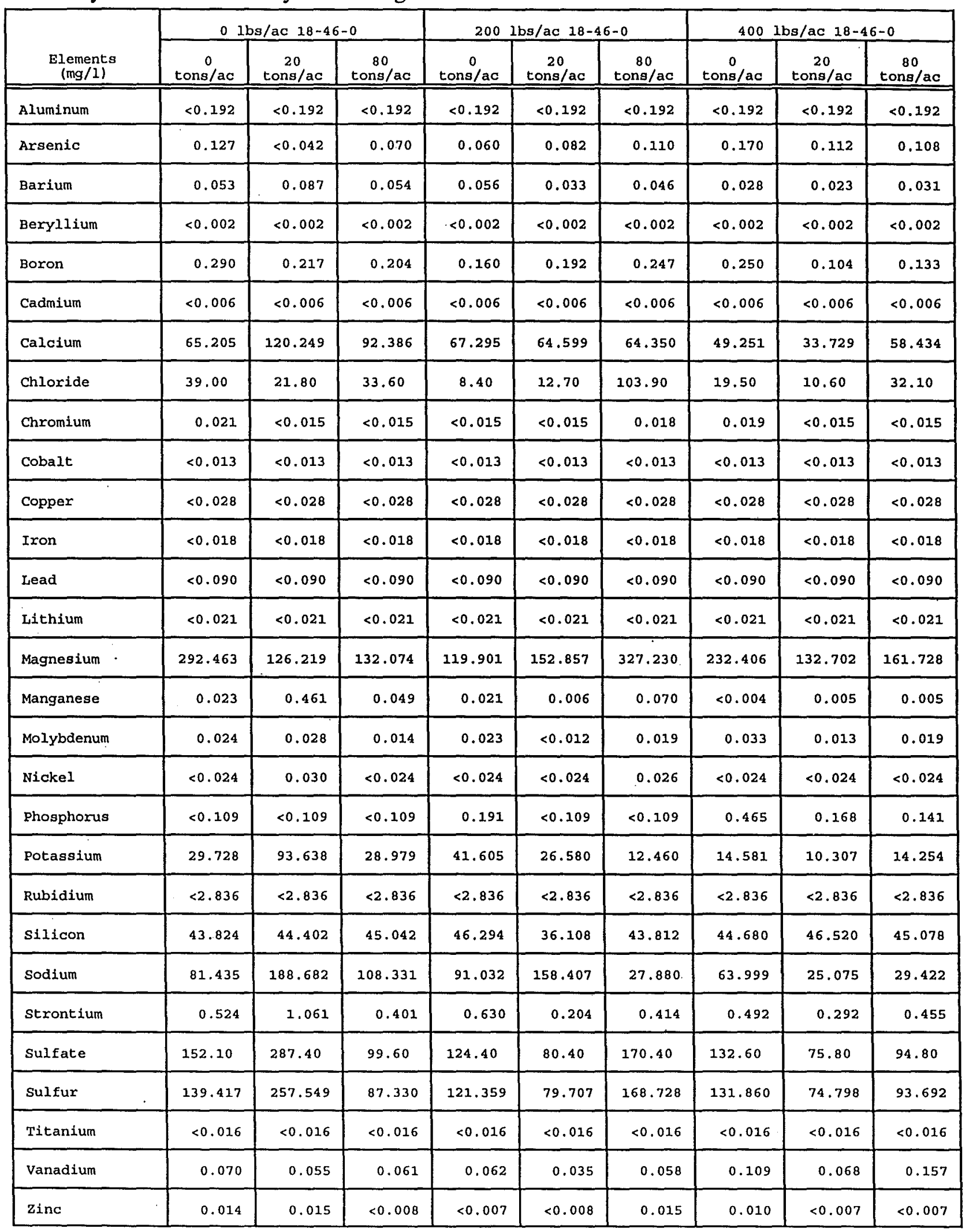


B-4.--Lysimeter water analysis for September 1992.

\begin{tabular}{|c|c|c|c|c|c|c|c|c|c|}
\hline \multirow[b]{2}{*}{$\begin{array}{c}\text { Elements } \\
(\mathrm{mg} / \mathrm{l})\end{array}$} & \multicolumn{3}{|c|}{$01 \mathrm{bs} / \mathrm{ac} \quad 18-46-0$} & \multicolumn{3}{|c|}{$200 \mathrm{lbs} / \mathrm{ac} \quad 18-46-0$} & \multicolumn{3}{|c|}{$400 \mathrm{lbs} / \mathrm{ac} \quad 18-46-0$} \\
\hline & $\begin{array}{c}0 \\
\text { tons } / a c\end{array}$ & $\begin{array}{c}20 \\
\text { tons } / \mathrm{ac}\end{array}$ & $\begin{array}{c}80 \\
\text { tons } / \mathrm{ac}\end{array}$ & $\begin{array}{c}0 \\
\text { tons } / \mathrm{ac} \\
\end{array}$ & $\begin{array}{c}20 \\
\text { tons/ac }\end{array}$ & $\begin{array}{c}80 \\
\text { tons/ac }\end{array}$ & $\begin{array}{c}0 \\
\text { tons } / \mathrm{ac}\end{array}$ & $\begin{array}{c}20 \\
\text { tons/ac }\end{array}$ & $\begin{array}{c}80 \\
\text { tons } / \mathrm{ac}\end{array}$ \\
\hline Aluminum & 0.856 & 0.650 & 0.812 & 0.962 & 1.040 & 0.853 & 1.003 & 0.961 & 0.996 \\
\hline Arsenic & 0.165 & 0.095 & 0.145 & 0.166 & 0.175 & 0.168 & 0.257 & 0.221 & 0.211 \\
\hline Barium & 0.062 & 0.070 & 0.041 & 0.080 & 0.052 & 0.027 & 0.056 & 0.049 & 0.055 \\
\hline Beryllium & $<0.002$ & $<0.002$ & $<0.002$ & $<0.002$ & $<0.002$ & $<0.002$ & $<0.002$ & $<0.002$ & $<0.002$ \\
\hline Boron & 0.274 & 0.168 & 0.206 & 0.267 & 0.179 & 0.239 & 0.248 & 0.127 & 0.148 \\
\hline Cadmium & 0.019 & 0.013 & 0.019 & 0.022 & 0.023 & 0.019 & 0.023 & 0.022 & 0.021 \\
\hline Calcium & 55.780 & 140.950 & 35.483 & 94.048 & 54.218 & 14.973 & 49.108 & 27.588 & 50.156 \\
\hline Chloride & 5.20 & 5.70 & 12.00 & 1.70 & 11.10 & 47.10 & 6.20 & 5.80 & 26.00 \\
\hline Chromium & 0.068 & 0.043 & 0.057 & 0.065 & 0.070 & 0.071 & 0.076 & 0.065 & 0.069 \\
\hline Cobalt & 0.063 & 0.048 & 0.056 & 0.067 & 0.070 & 0.066 & 0.073 & 0.064 & 0.068 \\
\hline Copper & 0.117 & 0.089 & 0.108 & 0.231 & 0.140 & 0.118 & 0.146 & 0.132 & 0.137 \\
\hline Iron & 0.080 & 0.060 & 0.075 & 0.089 & 0.093 & 0.118 & 0.101 & 0.090 & 0.097 \\
\hline Lead & 0.246 & 0.165 & 0.237 & 0.274 & 0.299 & 0.255 & 0.294 & 0.287 & 0.294 \\
\hline Lithium & 0.103 & 0.073 & 0.096 & 0.105 & 0.113 & 0.094 & 0.106 & 0.104 & 0.108 \\
\hline Magnesium & 306.363 & 143.736 & 172.188 & 187.422 & 153.988 & 363.008 & 297.786 & 145.921 & 176.951 \\
\hline Manganese & 0.009 & 0.193 & 0.004 & 0.011 & 0.004 & 0.013 & 0.004 & 0.004 & 0.005 \\
\hline Molybdenum & 0.039 & 0.027 & 0.035 & 0.043 & 0.038 & 0.038 & 0.054 & 0.042 & 0.042 \\
\hline Nickel & 0.083 & 0.071 & 0.075 & 0.092 & 0.091 & 0.093 & 0.095 & 0.089 & 0.091 \\
\hline Nitrate & 39.2 & 11.7 & 4.4 & 12.2 & 12.2 & 0.7 & 133.7 & 6.4 & 3.4 \\
\hline Phosphorus & 2.524 & 2.231 & 2.274 & 2.426 & 2.384 & 2.304 & 3.565 & 2.668 & 2.557 \\
\hline Potassium & 27.501 & 84.647 & 29.941 & 36.095 & 22.574 & 14.117 & 14.047 & 9.267 & 13.398 \\
\hline Rubidium & 5.902 & 4.518 & 5.851 & 6.744 & 7.633 & 5.928 & 7.025 & 6.908 & 7.138 \\
\hline Silicon & 36.194 & 35.670 & 36.570 & 37.006 & 26.843 & 35.742 & 35.940 & 38.059 & 35.937 \\
\hline Sodium & 77.795 & 126.313 & 119.149 & 57.679 & 118.012 & 24.864 & 56.603 & 19.736 & 23.429 \\
\hline Strontium & 0.389 & 1.074 & 0.238 & 0.843 & 0.164 & 0.038 & 0.471 & 0.210 & 0.368 \\
\hline Sulfate & 154.10 & 300.80 & 72.20 & 196.20 & 99.80 & 200.50 & 157.50 & 72.00 & 104.30 \\
\hline Sulfur & 134.677 & 272.201 & 60.751 & 170.714 & 83.846 & 173.827 & 136.417 & 60.927 & 87.857 \\
\hline Titanium & 0.057 & 0.040 & 0.052 & 0.062 & 0.069 & 0.057 & 0.065 & 0.063 & 0.065 \\
\hline Vanadium & 0.127 & 0.096 & 0.115 & 0.134 & 0.128 & 0.123 & 0.171 & 0.141 & 0.179 \\
\hline Zinc & 0.013 & 0.042 & 0.008 & 0.013 & 0.012 & 0.015 & 0.018 & 0.011 & 0.013 \\
\hline
\end{tabular}


B-5.--Lysimeter water analysis for April 1993.

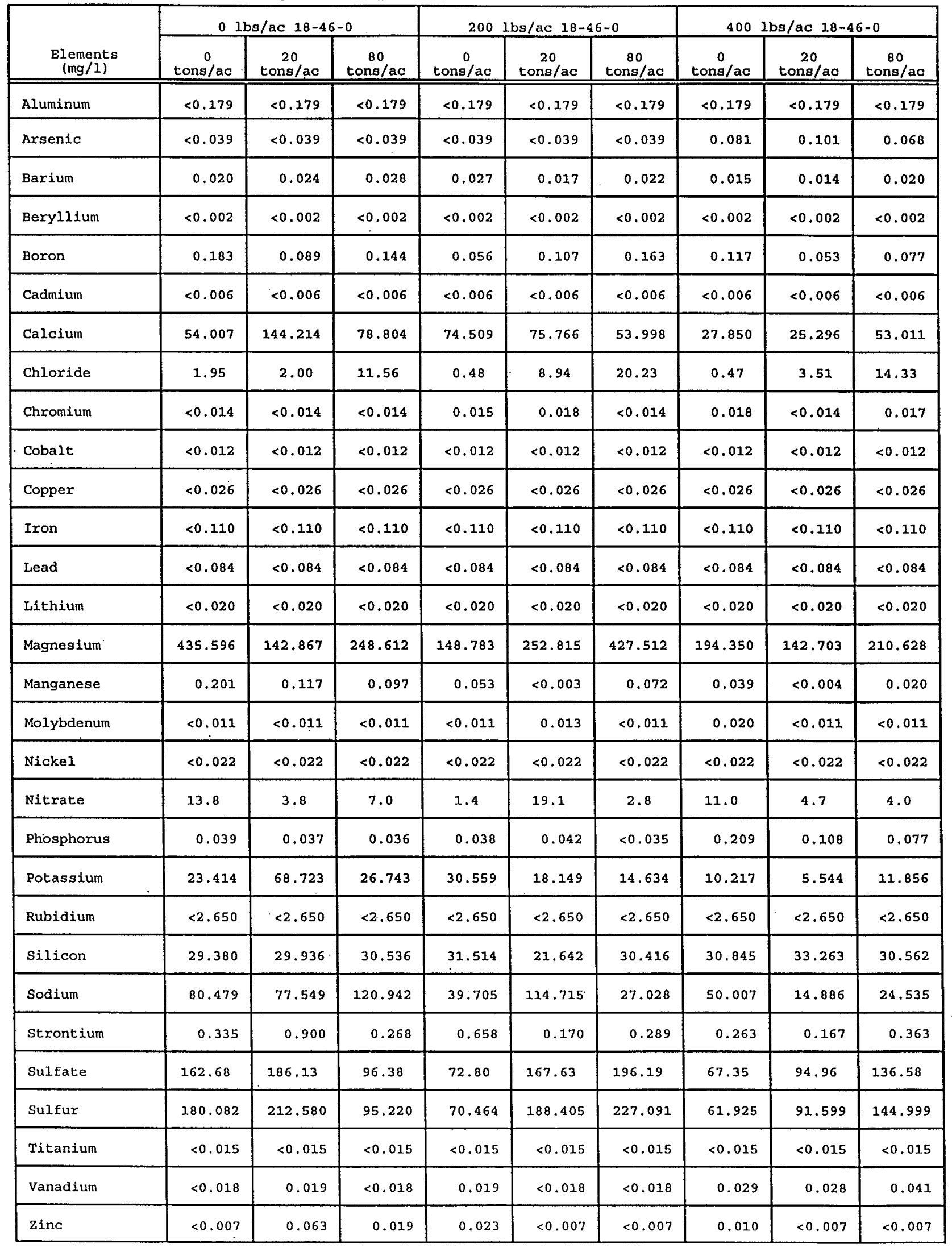


B-6.--Lysimeter water analysis for June 1993.

\begin{tabular}{|c|c|c|c|c|c|c|c|c|c|}
\hline \multirow[b]{2}{*}{$\begin{array}{l}\text { Elements } \\
.(\mathrm{mg} / 1) \\
\end{array}$} & \multicolumn{3}{|c|}{$0 \mathrm{lbs} / \mathrm{ac} \quad 18-46-0$} & \multicolumn{3}{|c|}{$200 \mathrm{ibs} / \mathrm{ac} \quad 18-46-0$} & \multicolumn{3}{|c|}{$4001 \mathrm{bs} / \mathrm{ac} 18-46-0$} \\
\hline & $\begin{array}{c}0 \\
\text { tons/ac } \\
\end{array}$ & $\begin{array}{c}20 \\
\text { tons } / \mathrm{ac}\end{array}$ & $\begin{array}{c}80 \\
\text { tons/ac }\end{array}$ & $\begin{array}{c}0 \\
\text { tons } / a c \\
\end{array}$ & $\begin{array}{c}20 \\
\text { tons } / \mathrm{ac}\end{array}$ & $\begin{array}{c}80 \\
\text { tons } / \mathrm{ac} \\
\end{array}$ & $\begin{array}{c}0 \\
\text { tong/ac }\end{array}$ & $\begin{array}{c}20 \\
\text { tons } / \mathrm{ac} \\
\end{array}$ & $\begin{array}{c}80 \\
\text { tons/ac }\end{array}$ \\
\hline Aluminum & $<0.179$ & $<0.179$ & $<0.179$ & $<0.179$ & $<0.179$ & $<0.179$ & $<0.179$ & $<0.179$ & $<0.179$ \\
\hline Arsenic & 0.062 & 0.044 & 0.061 & 0.042 & $<0.039$ & 0.068 & 0.091 & 0.080 & 0.071 \\
\hline Barium & 0.029 & 0.033 & 0.028 & 0.032 & 0.016 & 0.019 & 0.019 & 0.016 & 0.017 \\
\hline Beryllium & $<0.002$ & $<0.002$ & $<0.002$ & $<0.002$ & $<0.002$ & $<0.002$ & $<0.002$ & $<0.002$ & $<0.002$ \\
\hline Boron & 0.236 & 0.093 & 0.176 & 0.078 & 0.130 & 0.193 & 0.155 & 0.061 & 0.085 \\
\hline Cadmium & $<0.006$ & $<0.006$ & $<0.006$ & $<0.006$ & $<0.006$ & $<0.006$ & $<0.006$ & $<0.006$ & $<0.006$ \\
\hline Calcium & 38.999 & 133.464 & 59.970 & 81.717 & 58.290 & 43.310 & 30.684 & 23.389 & 40.754 \\
\hline Chloride & 0.98 & 2.44 & 3.35 & 0.53 & 2.22 & 8.16 & 0.38 & 1.40 & 5.79 \\
\hline Chromium & 0.015 & $<0.014$ & $<0.014$ & $<0.014$ & $<0.014$ & $<0.014$ & $<0.014$ & $<0.014$ & $<0.014$ \\
\hline Cobalt & $<0.012$ & $<0.012$ & $<0.012$ & $<0.012$ & $<0.012$ & $<0.012$ & $<0.012$ & $<0.012$ & $<0.012$ \\
\hline Copper & $<0.026$ & $<0.026$ & $<0.026$ & $<0.026$ & $<0.026$ & $<0.026$ & $<0.026$ & $<0.026$ & $<0.026$ \\
\hline Iron & $<0.110$ & $<0.110$ & $<0.110$ & $<0.110$ & $<0.110$ & $<0.110$ & $<0.110$ & $<0.210$ & $<0.110$ \\
\hline Lead & $<0.084$ & $<0.084$ & $<0.084$ & $<0.084$ & $<0.084$ & $<0.084$ & $<0.084$ & $<0.084$ & $<0.084$ \\
\hline Lithium & 0.024 & $<0.020$ & $<0.020$ & $<0.020$ & $<0.020$ & $<0.020$ & $<0.020$ & $<0.020$ & $<0.020$ \\
\hline Magnesium & 224.362 & 109.412 & 157.160 & 129.222 & 149.580 & 321.374 & 166.411 & 124.835 & 134.622 \\
\hline Manganese & 0.009 & 0.058 & 0.008 & 0.005 & $<0.003$ & 0.009 & $<0.003$ & $<0.003$ & $<0.003$ \\
\hline Molybdenum & $<0.011$ & $<0.011$ & $<0.011$ & $<0.011$ & $<0.011$ & $<0.011$ & $<0.011$ & $<0.011$ & 0.017 \\
\hline Nickel & $<0.022$ & $<0.022$ & $<0.022$ & $<0.022$ & $<0.022$ & $<0.022$ & $<0.022$ & $<0.022$ & $<0.022$ \\
\hline Nitrate & 6.4 & 2.4 & 2.9 & 1.6 & 4.5 & 1.8 & 3.3 & 2.5 & 1.6 \\
\hline Phosphorus & 0.065 & 0.049 & 0.066 & 0.068 & 0.058 & 0.048 & 0.231 & 0.122 & 0.087 \\
\hline Potassium & 26.955 & 54.460 & 23.903 & 28.121 & 17.472 & 15.205 & 11.786 & 7.358 & 14.737 \\
\hline Rubidium & $<2.650$ & $<2.650$ & $<2.650$ & $<2.650$ & $<2.650$ & $<2.650$ & $<2.650$ & $<2.650$ & $<2.650$ \\
\hline Silicon & 34.887 & 35.087 & 36.002 & 37.115 & 26.686 & 35.383 & 35.453 & 39.276 & 34.918 \\
\hline Sodium & 91.809 & 39.615 & 92.072 & 26.518 & 88.769 & 26.851 & 49.011 & 13.878 & 28.932 \\
\hline Strontium & 0.237 & 0.828 & 0.211 & 0.702 & 0.137 & 0.239 & 0.292 & 0.156 & 0.291 \\
\hline Sulfate & 70.48 & 186.74 & 45.19 & 87.77 & 71.04 & 120.82 & 82.79 & 50.86 & 68.46 \\
\hline Sulfur & 66.072 & 181.387 & 41.652 & 78.908 & 63.276 & 116.600 & 77.441 & 47.225 & 63.252 \\
\hline Titanium & $<0.015$ & $<0.015$ & $<0.015$ & $<0.015$ & $<0.015$ & $<0.015$ & $<0.015$ & $<0.015$ & $<0.015$ \\
\hline Vanadium & $<0.018$ & 0.020 & $<0.018$ & $<0.018$ & $<0.018$ & $<0.018$ & 0.022 & 0.022 & 0.031 \\
\hline zinc & 0.012 & 0.055 & 0.017 & 0.024 & $<0.007$ & $<0.007$ & 0.009 & $<0.007$ & $<0.007$ \\
\hline
\end{tabular}


B-7.--Lysimeter water analysis for August 1993.

\begin{tabular}{|c|c|c|c|c|c|c|c|c|c|}
\hline \multirow[b]{2}{*}{$\begin{array}{c}\text { Elements } \\
(\mathrm{mg} / \mathrm{l})\end{array}$} & \multicolumn{3}{|c|}{$0 \mathrm{lbs} / \mathrm{ac} \quad 18-46-0$} & \multicolumn{3}{|c|}{$200 \mathrm{lbg} / \mathrm{ac} 18-46-0$} & \multicolumn{3}{|c|}{$4001 \mathrm{bs} / \mathrm{ac} 18-46-0$} \\
\hline & $\begin{array}{c}0 \\
\text { tons/ac }\end{array}$ & $\begin{array}{c}20 \\
\text { tons/ac }\end{array}$ & $\begin{array}{c}80 \\
\text { tons/ac }\end{array}$ & $\begin{array}{c}0 \\
\text { tons/ac } \\
\end{array}$ & $\begin{array}{c}20 \\
\text { tong/ac }\end{array}$ & $\begin{array}{c}80 \\
\text { tons/ac } \\
\end{array}$ & $\begin{array}{c}0 \\
\text { tons } / \mathrm{ac} \\
\end{array}$ & $\begin{array}{c}20 \\
\operatorname{ton} s / a c \\
\end{array}$ & $\begin{array}{c}80 \\
\text { tons/ac } \\
\end{array}$ \\
\hline Aluminum & $<0.179$ & $<0.179$ & $<0.179$ & $<0.179$ & $<0.179$ & $<0.179$ & $<0.179$ & $<0.179$ & $<0.179$ \\
\hline Arsenic & 0.124 & 0.058 & 0.118 & 0.082 & 0.073 & 0.127 & 0.113 & $0: 081$ & 0.083 \\
\hline Barium & 0.040 & 0.051 & 0.044 & 0.051 & 0.019 & 0.026 & 0.022 & 0.030 & 0.028 \\
\hline Beryllium & $<0.002$ & $<0.002$ & $<0.002$ & $<0.002$ & $<0.002$ & $<0.002$ & $<0.002$ & $<0.002$ & $<0.002$ \\
\hline Boron & 0.254 & 0.100 & 0.186 & 0.097 & 0.154 & 0.242 & 0.022 & 0.030 & 0.028 \\
\hline Cadmium & $<0.006$ & $<0.006$ & $<0.006$ & $<0.006$ & $<0.006$ & $<0.006$ & $<0.006$ & $<0.006$ & $<0.006$ \\
\hline Calcium & 60.931 & 187.721 & 80.272 & 97.672 & 77.418 & 41.475 & 41.171 & 32.328 & 51.044 \\
\hline Chloride & 0.90 & 0.79 & 1.84 & 6.22 & 1.14 & 2.79 & 1.01 & 0.40 & 2.29 \\
\hline Chromium & $<0.014$ & $<0.014$ & $<0.014$ & $<0.014$ & $<0.014$ & $<0.014$ & $<0.014$ & $<0.014$ & $<0.014$ \\
\hline Cobalt & $<0.012$ & $<0.012$ & $<0.012$ & $<0.012$ & $<0.012$ & $<0.012$ & $<0.012$ & $<0.012$ & $<0.012$ \\
\hline Copper & $<0.026$ & $<0.026$ & $<0.026$ & $<0.026$ & $<0.026$ & $<0.026$ & $<0.026$ & $<0.026$ & $<0.026$ \\
\hline Iron & $<0.017$ & $<0.017$ & $<0.017$ & $<0.017$ & $<0.017$ & $<0.017$ & $<0.017$ & $<0.017$ & $<0.017$ \\
\hline Lead & $<0.084$ & $<0.084$ & $<0.084$ & $<0.084$ & $<0.084$ & $<0.084$ & $<0.084$ & $<0.084$ & $<0.084$ \\
\hline Lithium & $<0.020$ & $<0.020$ & $<0.020$ & $<0.020$ & $<0.020$ & $<0.020$ & $<0.020$ & $<0.020$ & $<0.020$ \\
\hline Magnesium & 227.624 & 119.522 & 169.252 & 119.59 & 179.544 & 242.085 & 183.189 & 134.045 & 117.647 \\
\hline Manganese & 0.004 & 0.062 & 0.004 & 0.004 & $<0.003$ & 0.004 & $<0.003$ & $<0.003$ & $<0.003$ \\
\hline Molybdenum & $<0.011$ & $<0.011$ & $<0.011$ & $<0.011$ & $<0.011$ & $<0.011$ & $<0.011$ & $<0.011$ & $<0.011$ \\
\hline Nickel & $<0.022$ & $<0.022$ & $<0.022$ & $<0.022$ & $<0.022$ & $<0.022$ & $<0.022$ & $<0.022$ & $<0.022$ \\
\hline Nitrate & 3.1 & 1.7 & 2.7 & 1.2 & 2.8 & 1.3 & 2.0 & 2.0 & 1.6 \\
\hline Phosphorus & 0.143 & 0.077 & 0.134 & 0.102 & 0.099 & 0.131 & 0.265 & 0.114 & 0.101 \\
\hline Potassium & 21.583 & 46.281 & 18.658 & 28.007 & 15.073 & 17.463 & 12.272 & 10.072 & 16.934 \\
\hline Rubidium & $<2.650$ & $<2.650$ & $<2.650$ & $<2.650$ & $<2.650$ & $<2.650$ & $<2.650$ & $<2.650$ & $<2.650$ \\
\hline silicon & 41.714 & 44.514 & 43.415 & 45.383 & 30.859 & 41.508 & 43.695 & 45.818 & 43.025 \\
\hline Sodium & 54.547 & 19.329 & 52.530 & 20.917 & 58.749 & 33.445 & 48.141 & 17.236 & 29.385 \\
\hline strontium & 0.332 & 1.072 & 0.282 & 0.835 & 0.187 & 0.241 & 0.389 & 0.213 & 0.369 \\
\hline Sulfate & 89.68 & 204.81 & 63.88 & 87.85 & 84.67 & 61.93 & 102.30 & 61.67 & 62.51 \\
\hline Sulfur & 88.200 & 234.269 & 60.927 & 84.551 & 78.092 & 58.307 & 102.651 & 58.774 & 59.320 \\
\hline Titanium & $<0.015$ & $<0.015$ & $<0.015$ & $<0.015$ & $<0.015$ & $<0.015$ & $<0,015$ & $<0.015$ & $<0.015$ \\
\hline Vanadium & $<0.018$ & 0.024 & $<0.018$ & $<0.018$ & $<0.018$ & $<0.018$ & $<0.018$ & $<0.018$ & 0.021 \\
\hline zinc & 0.013 & 0.054 & 0.013 & 0.009 & 0.012 & 0.009 & $<0.007$ & $<0.007$ & $<0.007$ \\
\hline
\end{tabular}


B-8.--Lysimeter water analysis for September 1993.

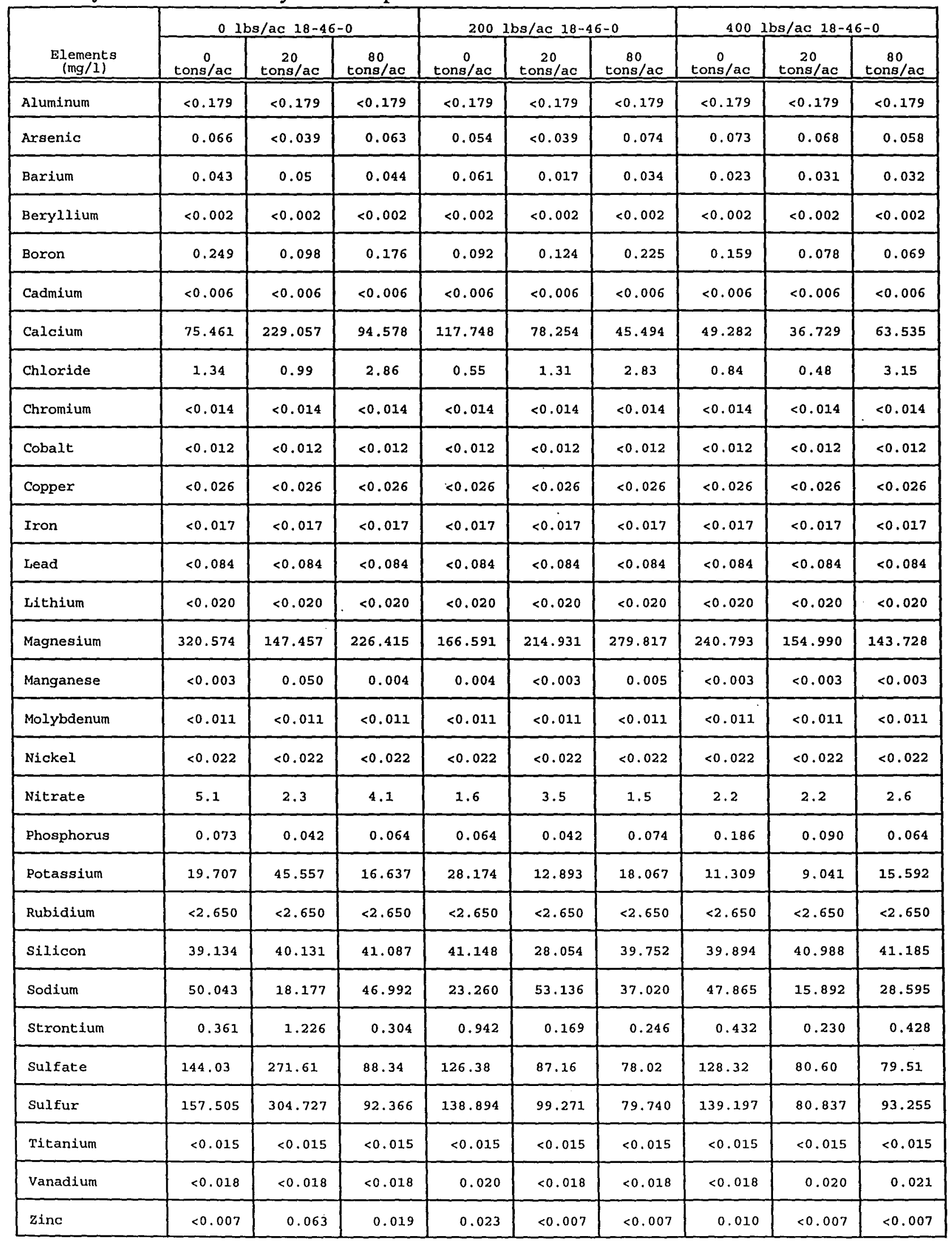

